This dissertation has been microfilmed exactly as received

$68-11,432$

JOYCE, Davis Darrell, 1940-

EDWARD CHANNING AND THE GREAT WORK.

The University of Oklahoma, Ph.D., 1968

History, general

University Microfilms, Inc., Ann Arbor, Michigan

C Davis Darrell Joyce 1968

ALL RIGHTS RESERVED 
THE UNIVERSITY OF OKLAHOMA

GRADUATE COLLEGE

EDWARD CHANNING AND THE GREAT WORK

A DISSERTATION

SUBMITTED TO THE GRADUATE FACULTY

in partial fulfillment of the requirements for the

degree of

DOCTOR OF PHILOSOPHY

BY

DAVIS DARRELL JOYCE

Norman, Oklahoma

1968 
EDWARD CHANNING AND THE GREAT WORK

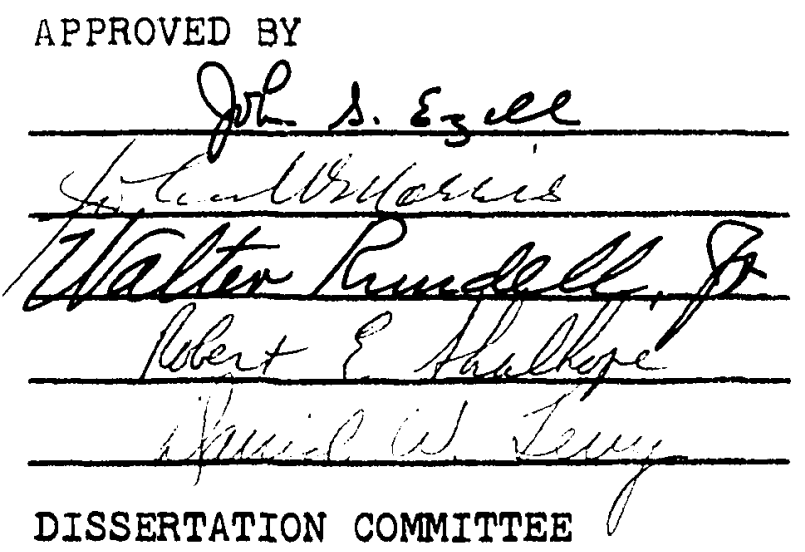




\section{ACKNOWLEDGMENTS}

Dr. John S. Ezell, my director, deserves my greatest thanks; he took an extensive 1nterest in the project throughout, even during the period when he was not actually the director. Dr. David E. Harre11, who acted as director for one year, was very helpful, especially considering the fact that he realized his connection with the project was to be a temporary one. Channing's daughter, Elizabeth Channing Fuller, and his grandson, W1llard P. Fuller, Jr., deserve speclal thanks among the Channing family members; Al1ce Channing, the other daughter, and John Channing Fuller, another grandson, were also he? oful. Two grants helped finance research trips, one from the University of Oklahoma, the other from the Un1versity of Tulsa. Dr. A. M. Gibson was instrumental in securIng the former, Dr. W. V. Holloway the latter. The staffs of the following librarles were all extremely cooperative and helpful: the University of Oklahoma, the UnIversity of Tulsa, Harvard University Archives, the Library of Congress, the New York Publ1c Llbrary, and the Massachusetts H1storical Soclety.

Mary W1Ison deserves a speclal note of thanks for speed$11 y$ and patiently working her way through the typing of the final draft.

Finally, how does one acknowledge the role of one's wife in a $\mathrm{Ph}$. $\mathrm{D}$. dissertation without engaging in the same trite comments repeated time after time? Suffice it to say that without LeQuita's support--and typing--this study simply would not exist. 
TABLE OF CONTENTS

Page

PRIPACE

v1

PART I. THE GREAT CHANNING

Chapter

I. EDWARD CHANNINO: A BIOGRAPHICAL SKETCH. - . 2

II. THE GREAT CHANNING. . . . . . . . . 25

PART II. THE GREAT WORK

III. THE PLANTING OF A NATION IN THE NEW WORLD. 59

IV. A CENTURY OF COLONIAL HISTORY . . . . . . 99

V. THE AMERICAN REVOLUTION . . . . . . . 132

VI. FEDERALISTS AND REPUBLICANS ........ 169

VII. THE PERIOD OF TRANSITION. . . . . . . 205

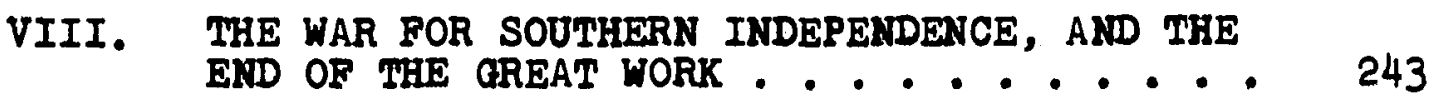

PART III. OTHER WORKS

IX. TEXTBOOKS . . . . . . . . . 297

X. MISCELlaneOUS writinas. . . . . . . 317

PART IV. AN EVALUATION

XI. EDWARD CHANNING, HISTORIAR. . . . . . 336

NOTES ON SOURCES. . . . . . . . . . . . . 37?

BIBLIOCRAPHY. . . . . . . . . . . . . 374 
Who faulteth not, l1veth not; who mendeth faults 1 s commended: The Printer hath raulted a little: 1t may be the author oversighted more. Thy pain (Reader) 18 the least; then err not thou most by misconstruing or sharp censuring; lest thou be more unchar1table, than elther of them hath been heedless: God amend and guide us a11.--Foulkes Robartes, quoted in Edward Channing's preface to A H1story of the United States. Volume I: The Planting of a Nation in the Ner World 10001660 (New York: The Macmilian Company, 1905), p. v11. 
Twenty years after Edward Channing's death in 1931, historlanis differed rather widely in thelr evaluation of his work. A British author, surveying American h1storlography since 1890, was quite critical of Channing's major contribution, the s1x-volume H1story of the United States, contending that it "won only a contemporary reputation which is not wearIng well." 1 Referring spec1fically to the second volume of the History, th1s writer stated h1s feeling that it "added little of substance to what was to be found in earlier works," and that it "was so partisan as sometimes to be quite misleading." 2

Qu1te a different view was expressed by an American h1storian writing in the same year. He felt that Channing seemed "assured of a nlohe in the historians' Hall of Fame as one of the glants of American historlography. "3 Many of Channing's flndings were new, this writer emphasized, and had been useful to other historians. He concluded that Channing's

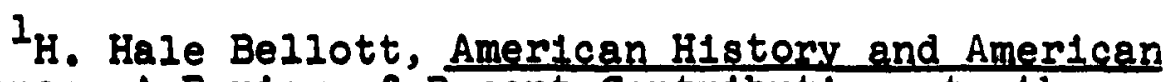
Historians: A Revier of Recent Contributions to the Interpretation of the Histony of the United States Norman: University of Oklahoma Press, 1952), pp. 7-8.

Ib1d., pp. 63-64.

3John A. DeNovo, "Saward Channing's lareat Work' Twenty Years After," Miss1ssipp1 Jilley H1storlcal Rev1eK, XXXIX (September, 1952), p. 257. 
History "wears well twenty years after his deatr," and, indeed, "remains one of the major accomplishments in the field of American historical writing."4

Some support is given to the latter interpretation by a poll of h1storians, once again dated 1952 , to determine preferred works in American history published between 1920 ind 1935. Channing's History finished eighth, following only the works of Parrington, Turner, Webb, Beard, Andrews, Becker, and Phillips. 5

There seems to be no doubt, at least, that Fdward Channing is an important figure in the history of American historical writing, and that his career and contributions deserve fuller examination than they have thus far received.

4 Ibid., p. 274 .

5 John Walton Caughey, "Historians' Cholce: Resuits of a Poll on Recently Published American History and Biography," Ib1d., p. 299. 
PART I

THE GREAT CHANNIMO

The man of action, the statesman, the soldier, the interpretative artist whose cochlevement passes in a moment, the music1an, the great actor--such men need blographers to set down what they have done. But an annotated history needs no history, double record, as 1t 18, of past events and of the process by which the truth about them has been found. And an historian's blography is not likely to make interesting reading, for his external life 18 not dramatic and one who watched him at his desk turning yellowed sheets of manusoript and printed record and then scribbling notes, relleved from time to time by littie journeys to the book-shelf, would soon grow tired of a spectacie so drearily monotonous. The exoltement of disoovery, the pride of we11-considered judgment, the bafeling searoh for logical conneotion in the ev1denoe, the pain of composition, cannot easily be made the oubjects of a narrative; fortunately the reader way ourmise then as he follows through the history. Yet this reader's our10sity may not al1 be slaked by Inference; he 18 likely to desire that the ploture of the author whioh ho forms in his uind' oye be pilied in by a few external facts, so that he may see more clearly the man with whom he has to deal. Such 18 the purpose of these pages.-Dixon Ryan Fox, Herbert leyt osrood. An American soholar (New York: Columbia UnIversity Press, 1924), pp. 13-15. 
EDWARD CHANNING AND THE GREAT WORK

CHAPTER I

EDWARD CHANNING: A BIOGRAPHICAL SKETCH

... I am related nore or less to all the "Highnesses"...

Somewhere in print I have proclaimed that the recollections of old men have long been under the ban of the scientific researcher. Nevertheless, "Recollections" stands as the first word on the title page of the present volume. For one must find something to do in his old age, as there is a saying that Satan finds some mischief still for idle hands to do. To go back even further, behind any possible recollection of a man who was born in 1856 , it appears that among my earliest ancestors were invaders or Immigrants to England....2

Thus Edward Channing began his autobiography when he sat down to write in 1929, two years before his death. Th1s opening passage says a great deal about the man. H1s original remark about the validity of old men's reminiscences is indicative of his questioning approach to all historical sources--though the fact that he went ahead and wrote such a work anyway

${ }^{1}$ Edward Channing, "Recollections of a Hitherto Truthful Man," p. 2. Th1s is an incomplete, unpublished autoblography written by Channing in 1929-1930. It cons1sts of forty singlespaced typewritten pages, and is in the possession of Channing's daughter, Mrs. Willard P. Fuljer (Elizabeth Channing Fuller), of Chatham, Massachusetts. Her son, W1llard $P$. Fulier, Jr., of San Andreas, California, has recently (1967) edited and privately printed a limited number of coples of this work. The author wishes to thank these members of the Channing family for permission to use both versions of the work. AlI footnotes herein are to Mrs. Fuller's copy, referred to as "Recollections," unless otherwise noted.

$$
2 \text { Ib1d., p. } 1 \text {. }
$$


perhaps indicates that he was softening on this as he did on many other things. His dry sense of humor and tongue in cheek approach are also evident--as, Indeed, they are even in the title of this work, "Recollections of a H1therto Truthful Man." And finally, his comments as to his "earliest ancestors" can be taken as indicative of his determination to work out in as much depth as possible any historical problem.

Channing seemed proud of this country's history and of his family's role in it, and yet he was more than willing to be critical of elther when he felt that truth demanded 1t. One of the best storles 1llustrative of this trait was related by Channing himself. As a junior at Harvard, he once gave a classroom report on one of his ancestors, Francis Higginson, in a course taught by Henry Cabot Lodge. Channing, "believing," as he sa1d, "truth to be the basis of history," was quite critical of Higginson, referring "somewhat strenuously to the hypocrisy of a man who could be a Church of Englander on one side of the Atlantic and a Congregationalist on the other, at the end of a voyage of three months or so." As he passed Lodge's desk after class, Lodge stopped him and asked if he were aware that Higginson was one of his ancestors. When Channing replled affirmatively, Lodge asked, "Do you think it well to speak thus of your ancestors?" Typically, Channing's conclusion to the story was: "But he gave me $92 \%$ at the close of the course, the second highest grade in the class, so I felt that, after al1, the truth ought not to be desp1sed."3

$$
3 \text { Ib1d., p. } 3
$$


Channing's myth-destroying inclinations were doubtless greatly increased by just such ep1sodes as this.

There were many "greats" in Edward Channing's ancestry--as he sald, he was "related more or less to all the 'Highnesses'." Among his prominent forebears, in addition to Francis Higginson, were Thomas Dudley and Simon Bradstreet, both governors of colonial Massachusetts, and W1lliam Ellery, signer of the Declaration of Independence. ${ }^{4}$ Channings were also related to Cabots, Lowells, and Emersons. The famous W11liam Ellery Channing (1780-1842), founder of the American Unttarian Assoclation, was Edward Channing's great-uncle. But the member of the Channing family who recelved the greatest praise from Edward Channing's pen was his grandfather, Dr. Walter Channing (1786-1876), brother of William Ellery Channing. And with good reason, for Dr. Channing was the nearest thing to a father Edward ever had.

Edward was born on June 15, 1856, in Dorchester, Massachusetts. Just three months later, his mother died of consumption. She was Ellen Kilshaw Fuller (1820-1856), the sister of the famous journalist, critic, and soclal reformer, Margaret Fuller, Countess d'ossoll. Ellen must have been a woman of great fortitude to "bring up four ch1ldren with a casual poet for a husband." 5

4W1llard P. Fuller, Jr., has a very helpful Edward Channing "Ancestor Wheel" in a pocket inside the back cover of his edition of the "Recollections."

${ }^{5}$ Samuel Eliot Morison, "Edward Channing: A Memolr," Proceedings of the Massachusetts Historical Society, IXIV 
The "casual poet," Edward Channing's father, was

W1111am Ellery Channing (1818-1901). Upon Ellen's death, he

"completely washed his hands of all responsibility for the

five children, and went his own way during the remaining fortyflve years of his life." ${ }^{6}$ Indeed, he does not seem to have had a great deal of responsibility for them, even before her death. Ellery, as he is usually called to distinguish him from his uncle William Ellery Channing for whom he was named, was "a thorn in the side of the Channing clan,"7 "a black sheep in

(October, 1930-June, 1932), p: 251. This account, written shortly after Channing's death, is still the best brief evaluation of Channing avaliable. The other four chlidren of Ellery and Ellen were Margaret Fuiler, Caroline Sturgis; Walter, and Eugene.

(Channing, "Recollections," p.7.) According to Morison, Channing was inftially named

Henry, possibly after Thoreau, and was only chrlstened Edward Perkins Channing after he moved in with his grandfather walter Channing at age four. The Edward was for his great-uncle Edward Tyrrel Channing, the Perkins for his paternal grandmother's family. Morison says Channing liked his first name but detested his middle name because boys called him "Perky" and the Perkins family patronized him. Thus he dropped the Perkins after college days. (Morison, "Edward Channing," pp. 252-253.) Channing's grandson argues that the story about being named Henry was simply something Channing made up because "he delighted to.stretch a point to make a good story when on the subject of family matters." (Fuller edition of the Channing "Recollections," p. 42.) As a matter of fact, Channing did not say that his grandfather named him Henry, but simply that he considered doing so. Channing complained that people would not accept his lack of a middle name after he dropped the Perkins, saying "I think every letter in the alphbet has been bestowed on me in lieu of a middle name." (Ibid., p. 11.)

6Morison, "Edward Chaning;" p. 250.

7 Van Wyck Brooks, The Flowering of New England, 1815$1865[$ (New York:] E. P. Dutton and Company, Incorporated, 1936),
p. 284. 
an otherwise normal family." Even an obvious attempt at a whitewash of his career did not succeed, for 1 ts author had to conclude that "the worldly fallure was out of proportion to the worldly success." 9 The kindest evaluation of his poetry stated that it was "among the best of the Concord school"; more typlcal was Henry David Thoreau's comment that 1t was "In the sublimo-slipshod style."10

Edward remembered seeing his father only once, and he certainly seems not to have regarded him very highly. One of his acquaintances felt that he was proud of being a Channing, but ashamed that his father was a "weak" Channing. 11 He hardly mentioned his father in his autoblography, and summarized his parents' marriage by saying, "The pair lived together, and separated, and lived together again, and again separated."12 One of Edward's own daughters later remembered that Ellery's chlldren did not like him. She also recalled that one particular day when she was a little girl her father walked away from

8ohn Channing Fuller, "Edward Channing: Essays on The Man, The Teacher, and The Writer" (Unpublished senior honors thes1s, W1lliams College, 1943), p. .7. The author of this work 1s another of Channing's grandsons. The present author wishes to thank him for permission to use 1t, and the library at Williams College for making it avallable.

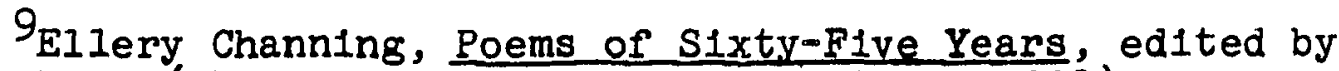
F. B. Sanborn (Philadelphia: James H. Bentley, 1902), p. xxxvi1.

10 Brooks, The Flowering of New England, p. 283; Townsend Scudder, Concord: Amerlcan Town (Boston: Littie, Brown and Company, 1947), p. 176 .

${ }^{11}$ Interview with Paul H. Buck, June 9, 1967, Cambridge, Massachusetts.

12 Channing, "Recollections," p. 7 . 
the house without speaking to her as usual. Jpon asking her mother where he was golng, she was told that it was to nis father's funeral. The 11ttie girl's innocent comment was, "He doesn't have a father."13 Apparently, Ellery Channing was seldom mentioned in the Edward Channing household。

Left alone by his mother's death and his father's desertion, It seemed likely that the puny little baby Edward would follow his mother to the grave. He was a seven-months baby anyway, and had been turned over to a wet nurse just after birth. Her sustenance proving inadequate, because she had a baby of her own, he was then entrusted to the wife of a shoemaker in South Abington, Massachusetts. He spent approximately the next four years of his life in this home. Channing's few memories of these years were fond ones, but one incident occurred whlch perhaps played a role in his leaving:

My older brothers and sisters took great delight in retelling to v1sitors how once golng to Abington I had been found alone in the house, the shoemaker and his wife having "gone to meeting" and having deposited me for safe-keeping in a deep shoe drawer, half open, where I was discovered sucking a lobster

Sometime in the year 1860 Edward was taken over by his grandfather, Dr. Walter Channing。

Dr. Channing was, as his grandson sa1d, "a remarkable man." Though dismissed from Harvard College as a Junior in 1807 for his role in a student rebelition over bad food, he

${ }^{13}$ Interview with Elizabeth Channing Fuller, August 19, 1966, Chatham, Massachusetts 。

$$
{ }^{14} \text { Channing, "Recollections," p. } 7 \text {. }
$$


later achleved great distinction as a physician, and was for thirty-three years Dean of the Harvard Medical School. 15 One of his major contributions to medicine was introducing the use of ether in childbirth. 16

W1th Dr. Channing lived his daughter, Edward's aunt, Barbara. She was "one of those forthright New England spinsters who always did as 'she'd a mind to,' with a lovable character and a warm heart which went out to the motherless little boy commltted to her charge."17 Aunt Barbara was a mother to Edward for many years; he loved her, and she h1m. ${ }^{18}$ Between 1860 and 1876, Edward lived with his grandfather and aunt in various places in and around Boston. He was a ra1l, slckly child, and one who had "a passionate love for companionship which was never satisfied."19 A description of the boy in 1861 by Thomas Wentworth Higginson, a relative with whom Channing was later to collaborate in the writing of a book, tells much of his appearance and personality at that t1me:

15 Ib1d., p. 4 .

$16_{\text {Henry R. V1ets, "Walter Channing," Dictionary of }}$ American Blography, IV, p. 4.

17 Morison, "Edward Channing," p. 154.

18 Interview w1th Ellzabeth Channing Fuller, August 19, 1966, Chatham, Massachusetts.

19 Morison, "Edward Channing," p. 154. 
.. Edward..ois becoming one of the most fascinating little creatures who ever lived; a sort of male falry; blue eyes, long soft ha1r and the most plaintive little expression, with a low tender volce like a nursing angel and all the character and individuality of a Channing and a Fuller combined. He is not shy or plteous now, but healthy and gay, only on a low gentle scale, his loudest warwhoop a sort of med1tative sol1loquy. His one chosen companion is the imaginary Mr. Dowdy, whose 1ndividuality is hopelessiy intertwined with his own, he is Dowdy, but Dowdy is not he; - In fact, as he confidentialiy whispered to me "There's a great many of them"; he peoples the world with Dowdies. All his small rebelilons, not very frequent, are conducted with reference to novel first principles. "Don't you want to be good" remarks Auntie solemnly; "No" says the seraph very gently, shaking his tresses, as if he saw no force in that aspect of the casem"I don't want to be good." "Don't you want to please yourr friends?" "No," answers the little saint sweetly, "I don't want to peese my fends"; and thus the ordinary grounds of domest1c discipline prove hopeless. What to do with a disputant whose tones only become more soft and celestial amid sin and retribution?20

As Samuel Eliot Morison sa1d, "Truly, this boy was father to the man! Edward Channing never did 'want to be good,' nor was he ever much concerned with pleasing his friends or anyone else."21

Channing's own memories of this period are interesting and sometimes revealing. He recalled very little of the Civil War years--just seeing soldiers march off to war, being employed In the making of bandages, and hearing the cry in the streets, "Lincoln is murdered!" It was on the day that he heard that

20 Quoted in Ib1d., pp.254-255. For more Mr. Dowdy stories, see Thomas Wentworth Higginson, Part of a Man's Iife (Boston: Houghton, Miffiln and Company, 1905), pp.36-38.

${ }^{21}$ Mor1son, "Edward Channing," p. 255. 
tragic news that young Edward was allowed to venture out of the house alone for the first time-to buy a newspaper. Later he bought a large wooden star from the carpenter, which was covered with black cloth and placed above the front door of the house.22

Except for his frallty, Edward was a normal child. He was "put out to grass in the country," as he put it, in the summers beginning in 1865, living with a farm family named Hewes in Weston. He remembered being thrown into a poison Ivy patch by the country boys on h1s first vis1t there (he was 1mmune) and then jolning his former tormentors in the harassment of an old woman they consldered to be "the town witch." "Whenever we threw stones at her front door," he recounted, "she would come out with a broom preparatory to riding through the air, as we thought, but no doubt more desirous of banging her persecutors."23

Channing's upbringing had a religious nature which made a lasting 1mpression on him. "The Sabbath," he recalled, "was then the Sabbath."

It was not a day of rejolcing and of tearing around the country on pleasure bent. On the contrary, it was the day to reckon up one's misdeeds of the past week and make resolves for better doing in the future. On Saturday night, the gate leading into the front yard was closed at sundown, the horses given a day of rest, and feeding them and the pigs, and driving the cows to and from pasture and milking them was the

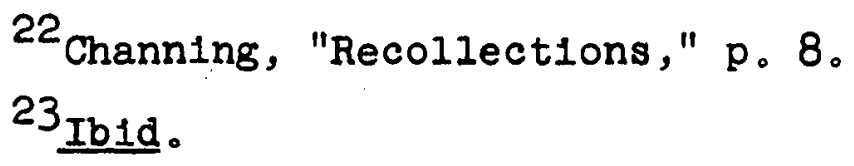


only work that was done on the farmo.o.Everyone put on his or her best attire to go to meeting. On one occasion, Albert, the grown-up son, pulling on his Sunday boots with great difficulty, ejaculated, "By George, that hurts!" Whereupon his mother told him to stop swearing, which he did 1mmediately. We walked to meeting in the morning, and the small ones stayed after to attend Sabbath School. We had a cold dinner and went back to meeting for the afternoon. After supper, we boys gathered in the road in front of the house, and gazed hopefully into the sky for the sight of the first star, for then Sunday was over and one could play; for in those days the Sabbath began at sundown on Saturday and ended with the coming of the first star on Sunday.24

Channing later referred to himself as "an ev1l disposed youngster," but he actually seems to have been just a normally Independent and mischievous young boy. He detested the attempt of his Aunt Barbara to have him taught piano and dancing, and managed to get out of the latter by kicking his lady teacher on the shins. 25 Keeping hens was one of his favorite hobbles, and proved to be a profitable occupation when he began to seli. eggs to the neighbors; ${ }^{26}$ he was always fond of animals

As a student, Edward left much to be desired. His frall physical condition of ten kept him out of school, and he was a rather dull scholar when he was present. At least part of the reason seems to have been his eyes; he had constant headaches from this problem, and it was not until he was grown and married that a doctor findily discovered his astigmatic

$$
\begin{aligned}
& { }^{24}{ }_{\text {Ib1d. }}, p p \cdot 8-9 . \\
& 25_{\text {Ib1d }}, p_{0} 10 . \\
& 26_{\text {Ib1d. }}, p_{0} 12 .
\end{aligned}
$$


condition and prescribed the glasses which helped correct $1 t .27$ Even at that, his eyes troubled him in later $11 f^{\circ}$ 。 Channing prepared for college at W1lliam M。Eayres' private school in Boston, and took his Harvard entrance examInations in September of 1873. He was admitted, but with six "conditions," the largest number allowed, and he remembered Presldent Charles $W_{0}$ Ellot greeting him as an incoming student in the fall of 1874 w1th the comment, "A good many cond1tions, Mr. Channing." In view of all his handicaps-"conditions," bad headaches, and required studies which he detested--Channing was rather proud of his record. "I got two more conditions in my Freshman year," he reported, and then went on proudly,

and in due course graduated Magna Cum Laude w1th Honors in H1story, and two years later attained the $\mathrm{Ph}, \mathrm{D}$. degree in H1story. Surely if the elective system ever needed justification, it would be found in my case, for the moment I got away from mathematics and the dead languages, I went ahead.28

In another place, Channing summarized his college years by saying, "My flrst two years were spent in 1dieness, but my grandfather's death brought me to my senses, and since then I have tried to do my duty."29 Walter Channing died in

27 Ib1d., p. 21; and Mor1son, "Edward Chann1ng," p. 256. 28 Channing, "Recollections," pp. $12=14$.

29 This is from Channing's brief, self-written notice in the Harvard "Class Book, 1878," In the Harvard Unlversity Archives. 
1876, and Edward, who of course had already shown a marked tendency to be independent, was now of necessity completely on his own, except for the three hundred dollars he recelved from his grandfather's estate.

During his two years of "1dleness" at Harvard, Edward was involved in some interesting capers. He resented being required to attend morning prayers at $7: 15$. Here is the way he remembered 1t:

Before long, I was confined to my bed...with a sore throat. Scenting possible advantage, I made up a good story as to the dampness of the chapel and the hazards of sitting in it before breakfast, unfortifled by food. The physiclan fell in with my scheme, and gave me a certificate of "tendency toward sore throat," which relieved me from attendance at prayers from the first of November to the first of May. And, as I carried my allowance of "cuts" over into the prayer-going period, I managed to attend prayers for only about six weeks in the year.30

Channing was also called before the dean once for sleeping in class, and he kept both pets and boats in h1s room in violation of the spirit, if not the letter, of university regulations. 31

Once he came to his "senses," however, Channing showed great ab1lity and initiative in h1s Harvard career. Though these were, in his own words, "years of financlal disaster and gloom," he managed to pull through. He did so by such devices as lecturing to large groups of students, "charging a dollar a

${ }^{30}$ Channing, "Recollections," p. 15.

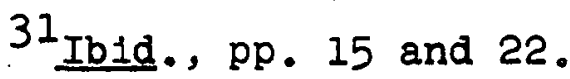


head"; becoming the partner of a student who bought books directly from the publisher and sold them to students under the bookstore price, but at conslderable prof 1 t to himself; and by buying up several hundred dollars worth of stock in the Old Colony Ra1lroad and selling it a few days later "at the top of a rather sharp ascent," clearing about three hundred dollars--the beginning of a life-long habit of speculation in stocks. 32

Academically, also, Channing made marked 1mprovements after the first two years. Typ1cal was the way in which he worked off his "condition" in mathematics in his senior year. It was a subject which he hated, but, realizing the necessity of fulfilling the requirement, he simply shut himself in his room and studied unt1l he was able to pass $1 t .33$

Encouraged both financially and academlcally, Channing was able "to look with greater calmness on the prospect of two or three years of post graduate study and the attainment of a couple more degrees, an A.M. and a Ph.D." 34 The rinanclal encouragement was the result of a two hundred and fifty dollar scholarship awarded to Channing in his senfor year and Increased benef1ts from h1s grandfather's estate. Academically, the uplift was provided positively by Henry Adams and

32 Ib1d., pp. 16-17. Channing's description of h1s own financial situation applied to the country as, a whole, of course, after the Panic of 1873.

33 Fuller, "Edward Channing," p. 13.

34 Channing, "Recollect1ons," p. 16. 
negatlvely by Henry Cabot Lodge. Channing never lost the high regard he galned for Adams, writing of him in his "Recollections:"

I cannot express--no words of mine could--the debt that I owe to Henry Adams. He was the greatest teacher that I ever encountered. He could draw out from a man the very best that was in him. 35 . There was never any other man like Henry Adams. 35

Channing attributed his entrance into the fleld of history to Adams. He took Adams' course, Advanced Medieval Institutions, in his junlor year, and his research topic was a comparison of the marriage institutions of the Germans in the time of Tacitus with those of the North American Indians. Recalled Channing:

... I labored and produced an essay which I no longer possess but on which he kindly placed the mark of one hundred percent. That essay was my undo1ng. I had been designed by my grandfather for the law, but I abandoned 1 t for history. 36

If Channing's evaluation of Adams was f1lled with praise, his few comments on Henry Cabot Lodge were fllled with critlc1sm. We have already seen the difference in thelr att1tude toward ancestors. Channing used to say of Lodge that after the s1ze of his classes dropped from fifty to three,

\section{Ib1d., pp. 20-21. \\ 36} Ibjd., p. 20. It certainly must not have been easy grading on Adams. part wh1ch appealed to Channing, for according to one source Channing finished. Fourth out of elght in one of Adams' classes, with a grade of only 70 when the high was a 90-12/15.--Stewart M1tchelI, "Henry Adams and Some of His Students," Proceedings of the Massachusetts H1storical Soc1ety, IXVI (October, 1936-May, 1941) p. 298. 
Lodge decided to give up teaching for politics.37 It might be sald, then, that Adams' example and Lodge's dogmatism-along with, as well, the blas of the current text, Richard Hildreth--first caused Channing to enter the field of history. Specifically, he concelved a plan to write an objective United States history from the sources, and began to accumulate notes even before recelving his bachelor's degree. 38

Once he made the decision to go on to the Ph.D., Channing wasted no time. Since he graduated with honors in history in the class of 1878 , he was not required to take the general examination as a part of the Ph.D. program. This enabled him to concentrate on his dissertation on the Loulsiana Purchase, a project completed by February of 1880. H1s memory served him well when he later recalled that "it must have been appalling reading." 39 Th1s was true, however, more as a result of mechanical matters than because of content. The work consisted of seventy-elght hand-written folio-size pages--and, as Channing realized, his "chlrography was rather blind."40 Also, he must have taken serlously the continual dictum of the

37 Paul H. Buck, ed. Soc1al Sclences at Harvard, 18601920: From Inculcation to the Open Mind (Cambridge: Harvard Un1versity Press, 1965), p. 148.

38 Morison, "Edward Channing," p. 260.

${ }^{39}$ Channing, "Recollections," p. 18.

40 Ib1d. The dissertation is avallable in the Harvard University Archives. As for Channing's coverage of the subject, it was quite adequate; much of what he sald there later found its way into the appropriate volume of his major History. 
Harvard College Catalog around the turn of the century that "Knowledge of German $w 111$ be of advantage in any of the courses in History and Polltical Sclence; and abllity to make use of French text-books $w 111$ be assumod," 41 for he "swept up everything in French and English in the Harvard I1brary, "42 and used quotations from the French sources rather extensively. In general, it is no wonder that the committee stalled for time before holding his examination over the work, and that he had to read it aloud to some of them to get the1r approval! Finally, weeks after he had submitted the dissertation to the committee and st1ll had heard no word from them, Channing applied pressure and the examination was held. The committee consisted of Henry W. Torrey, Cha1rman, James Barr Ames, Ephraim W. Gurney, Henry Adams, and Henry Cabot Lodge. It must have been a strange session Indeed. Channing suffered from a throbbing toothache, which put him "In good fighting trim and prepared for eventualities, many of them." All the committee members declined to question him, so Chalrman Torrey was forced to carry the burden himself, "and he found it pretty hard sledding." He was able to keep it up for only about half an hour. Channing was then told to leave the room for five minutes.

I went out, and lay at full length on the grass in front of the steps of Harvard Hall, and by reason of

$$
\begin{aligned}
& { }^{41} \text { Harvard College Catalog, 1897-1898, p. } 341 . \\
& { }^{42} \text { Channing, "Recollectlons," p. } 18 .
\end{aligned}
$$


the pain in my head, cursed the committee and all Its works....At the end of five minutes, I mounted the steps and reentered the room and was informed by the chairman that I had passed and would receive the degree of Doctor of Philosophy at the next commencement. I exhibited all the gratitude that I could.... 43

By the time he received the $P h . D$, Channing knew definitely what he wanted to do--teach United States history at Harvard. But his application to President Charles William Eliot for such a position recelved the reply that there was none, along with a comment that well described the academic status of the fleld at that time:

Your desire to teach American history is a laudable one; but you of course recognize the practical necessity of having other strings to your bow. There are only two colleges in this country within my knowledge where much is made of American history, and you know how elementary the teaching on that subject is in American schools. H1story is generally taught by $\mathrm{q}_{4}$ master who has several other subjects on his hands. 44

Channing did not give up his goal, but because of Increased benef1ts from his grandfather's estate, he was able to postpone 1t. "Two years after my graduation," he wrote later in the 50th anniversary report of the Class of 1878 , "I received my Doctorate in History at Harvard University and at once salled for Europe."

Channing landed at Havre, and in the course of his travels went as far north as East Frlesland and Lubeck, as far

$$
\begin{aligned}
& 43 \text { Ib1d., p. 19. } \\
& 44 \text { Quoted in Morison, "Edward Channing," p. } 263 .
\end{aligned}
$$


east as the Black Sea, and as far south as Tun1s. "After nine months I salled for home," he recalled, "having galned a new outlook on the world, which has been of great service to me ever since as a teacher and writer on history and geography." 45

Morlson felt that the tour "opened new v1stas for Channing, enriched his knowledge, and kindled his 1magination." 46 However, Channing included nothing in his "Recollections" to indicate that he took 1 t anywhere near that seriously. "The Grand Tour," as he called the chapter on that subject, was a light-hearted account of fleeting affairs with young members of the fairer sex and of such incldents as the one in which he and an acquaintance tried "some rare Greek wine":

It had all the appearance of water. We poured some into two tumblers, drank it off and soon our heads began to spin. When we came to, we cast the remainder overboard, and from that time on we were able to understand why the Greeks were so rambunctious at Troy and elsewhere. 47

The unemployed young $\mathrm{Ph} . \mathrm{D}$. returned to Cambridge in June, 1881. Sald he, "The next two years were spent in writing book notices and fugitive pleces." 48 The book reviews were very few in number; the "fugitive pleces" were primarliy geographical articles for Sclence--on such diverse topics as "The

45 Harvard College Class of 1878: Secretary's Report, No.VIII, Fiftieth Anniversary Report, 1928, pp. 48-49. 46 Morison, "Edward Channing," p. 264. 47 Channing, "Recollections," p. 26. 48 Harvard College Class of 1878: Secretary's Report, No. II, 1884, p. 26. 
Sudan," "Roads from India to Central Asia," and "GeographyTeaching in Germany." 49 It was in the course of his geographlcal work that Channing first met the great historlancartographer-11brarian Justin Winsor, whom Channing referred to as "one of the remarkable men of that time."50 Channing later wrote two chapters for Winsor's Narrative and Critical History of America.

Wh1le he was thus occupled, Channing kept his eyes open for possibilities in the Harvard h1story department. He was alded in dolng so by his close assoclation with his dissertation director, Professor Torrey, who was about ready to retire. 51 Channing recelved an appointment at the instructor level in 1883, his first assignment aiding Torrey in a course on the history of treaties. 52

Channing's historical writing began the same year as his teaching career. He won the Robert N. Toppan Prize of

49 George $W$. Robinson, Bibliography of Edward Channing (Cambridge: Harvard University Press, 1932), pp. 5-7。 Th1s little volume lists most of Channing's writing, excluding only "Numerous short articles and reviews, editorials, notes, syliabi, and the like." (p. 5).

${ }^{50}$ Channing, "Recollectlons," p. 32. Channing also spoke very highly of Winsor in an article written just after Winsor's death in the American H1storical Review, III (January, 1898), pp. 197-202.

51For some reason, Channing stated in the "Recollect1ons" that he "then had no thought of teach1ng." ( $p_{0} 33$ ) But why else would he have applied for the position in 1880, and why would he have jumped at the first opportunity to teach something even he was not particularly interested in?

52 Morison, "Edward Channing," p. 265. 
two hundred and firty dollars for an essay entitled "Town and County Government in the English Colonies." Published the following year as a volume in the Johns Hopkins University Studies in H1storical and Political Sclence, this little work also helped him get elected to the elite Massachusetts H1storical Society, and was presented in briefer form by Channing as the first paper at the first meeting of the American Historlcal Association at Saratoga, New York, in 1884.53

Another major move for Channing came three years after the Harvard appointment. At the home of Thomas Wentworth Higginson he had met Allce Thacher, Higginson's sister-1n-law。 Marrled July 22, 1886, they had two ch1ldren. Allce was born on May 12, 1888, El1zabeth Torrey--named for a s1ster of Pro= fessor Torrey--on January 9, 1892.

Instructor Channing advanced steadliy through the academ1c ranks. He became Ass1stant Professor in 1887, Professor in 1897, McLean Professor of Anclent and Modern History in 1912, and McLean Professor of Anclent and Modern H1story, Emeritus, in 1929.54

Channing's publications came out rather rapidiy also, and doubtless helped account for some of his promotions. H1s first really major work was the Gulde to the Study of American H1story, done in association with Albert Bushnell Hart and

\section{Ib1d., p. 267.}

54 Harvard University. Gazette, January 10, 1931. (In Channing's folder of the "Quinquennlal File" of Clippings on Harvard Men, in the Harvard University Archives.) 
publ1shed in 1897. In that same year The United States of Amer1ca, 1765-1865, a little volume in the Cambridge Historical Series, came out. By this time, Channing had already published another volume in the Johns Hopkins Studies, an English history text in association with Thomas Wentworth Higginson, and numerous articles; he had also begun with Hart, In 1892, the editing of the series of documents they calied American History Leaflets: Colonial and Constitutional. Professor Channing's major textbook, A Students' History of the United States, was first published in 1898 and went through four more editions by 1924. Later texts for various levels were: A Short History of the United States for School Use (1900); First Lessons in United States History (1902), and Elements of United States H1story, with Susan J。Ginn (1910)。 The Jeffersontan System, 1801-1811 (1906) was Channing's contribution to Hart's famous American Nation Series. Channing also co-authored The Story of the Great Lakes w1th Marion Florence Lansing in 1909; and Frederick Jackson Turner's name was added to those of Channing and Hart for a new edition of the Guide in 1912.

Once he began to work on his major undertaking, the six-volume History of the United States, Channing took little time for anything else. After the first installment in 1905, The Planting of a Nation in the New World, 1000-1660, the volumes appeared at approximately four-year intervals until the Pulitzer Prize-winning volume VI on the Civil War era was 
published in 1925. After that, it became obvious that Channing's age was slowing him down conslderably. He st1ll had not finlshed volume VII when he died of a cerebral hemorrhage on January 7,1931 - only the night before he had st1ll been working on the History:

"The most eminent of contemporary American writers of Un1ted States h1story is gone," sald the Boston Herald the next day. This was typical of the newspaper comments on Channing's death, and the funeral service was a fitting one for a historian of such distinction. Held at noon on January 10 In Harvard's Appleton Chapel, over three hundred people were in attendance. "During the hour of the funeral all classes were suspended, a tribute accorded no one else during my connection with Harvard," recalled Arthur M. Schlesinger。 55 President A. Lawrence Lowell was among those present at the service, conducted by Reverend James Hardy Ropes of the Harvard Theological School. The ushers were fellow historlans Hoger B. Merriman, Henry A。 Yeomans, James P. Baxter, Lawrence S. Mayo, A. C. Potter, George P。W1nsh1p, Arthur M。 Schles" Inger, and Samuel Eliot Morison. 56 The latter's tribute, written shortly after Channing's death, is a fltting one:

55 Arthur M. Schlesinger, In Retrospect: The H1story of a Historian (New York: Harcourt, Brace and World, Incorporated, 1963), p.86.

${ }^{56}$ This account is based on clippings in the Channing "Quinquennial File" folder. 


\section{4}

Channing accomplished what no man had done before, and what is not likely to be done again. Between his fortleth and his seventleth year, with h1s own hand, and from his own research, he wrote a great history of the United States from the beginning of colonization to the close of the civil War. In the meantime, he trained scores of men to carry on the work in his own spirit of thorough and fearless inquiry; and to thousands more he imparted a love of our country's history, based on knowledge. For this he sacrificed much that men hold dear; but gained what was more dear to him: recognition, and affection. The little motherless boy, who for want of a companion created an 1maginary "Mr. Dowdy," died a ripe scholar of seventy-four, the head of his profession. 57

57.Morison, "Edward Channing," p. 284. 


\title{
THE GREAT CHANNING
}

\begin{abstract}
"My father wished me to inquire what relation you were to the great Channing?" once Inquired a shy student of our Edward. "I am the great Channing!" was the characterisłic reply, delivered w1th a thump on the breast bone. 1
\end{abstract}

Those who knew Edward Channing always describe h1m in vivid terms, and usualiy do not differ appreclably in their comments. Arthur M. Schlesinger, who met Channing the first t1me in the summer of 1913, remembered him as "Short and rotund with protuberant blue eyes and ruddy cheeks, .. not at all the 1mposing flgure I had 1mag1ned." To Schlesinger's wldow, Channing seemed like "a l1ttle pouter plgeon," with h1s red cheeks, white ha1r, etc. Her comments are similar to those of another acqualntance who described Channing as a "poppy" man: with pop-eyes, pop-cheeks, and a pop-stomach. The Charles Hopkinson portrait of Channing in the Union Catalog room of Harvard's Widener Library bears out all these remarks. Samuel El1ot Morison felt that this "admirable" painting expressed Channing's 'unique combination of sauvagerie

$1^{1}$ Samuel Ellot Morison, "Edward Channing: A Memo1r," Proceedings of the Massachusetts H1storlcal Soc1ety, LXIV (October, 1930-June, 1932), p. 252. 
and friendiness."2 It shows a stout, white-haired, baldish man, with a round, red face. It also depicts an erect, proud, dignifled individual. And one really can see both a gruffness and a kindness; though perhaps one would see that in the por trait as a result of having heard comments about Channing's personality from those who knew him.

Some have tried to explain Channing's personality in terms of differences between him and his father. Morison, for example, sald, "He was in almost every respect the opposite to his father." 3 Certainly, in some ways, this was true. If, as Thoreau said, Ellery Channing were a man of "all genius and no talent," Edward Channing, was, as Morison sa1d, a man of "all talent, talent carried to a high degree by hard, unremitting industry." 4 If Ellery Channing were "a man who wanted things but would never pay the price," 5 Edward Channing was a man who paid a high price all his life to accomplish his one great goal. And, of course, Edward Channing apparently did not think very highly of his father--1ndeed, was perhaps even ashamed of him。 St11l, in more ways than Edward Channing himself would have realized or admitted, he was very much like his father.

${ }^{2}$ Arthur M.Schlesinger, In Retrospect: The History of a Historian (New York: Harcourt, Brace and World, 1963), p。 51; Interv1ew w1th Mrs。Arthur M.Schlesinger, August 30, 1966, Cambridge, Massachusetts; Interview with Robert $H_{0}$ Haynes, August 24, 1966, Cambridge, Massachusetts; and Morison,

"Edward Channing," p.283.

3 Ib1d., p. 251

4 Ib1d.

5ownsend Scudder, Concord: American Town (Boston: Little, Brown and Company, 1947), p. 176 。 
First of all, their early lives were quite similar-Ellery's mother too died early, and he was ralsed by a great aunt; both developed an early and lasting love for animals; Ellery too resented the required chapel attendance in his Harvard days. Here are some phrases that were used to describe the personal1ty of Ellery Channing: "a lively and humorous turn of mind," "superficial petulance and Impatience," "typ1cal Boston eccentric," a "social outlaw" who "loved solitude."6 All are baslcally applicable to Edward Channing as well. And finally, Morison, in spite of h1s emphasis on differences between father and son, could have been talking about elther when he sald of Edward Channing that he "never did 'want to be good, ' nor was he ever much concerned with pleasing his frlends or any one else." 7

Indeed, th1s last statement hints at the most 1mportant tra1t which Channing had in common with h1s father--h1s Intensely independent, individualistic spirit. Once again in Morison's words, "Edward Channing was Edward Channing, and nothing else. He followed h1s own bent and formed h1s own oplnions, Independent of fashion, example, and Influence. "8

6 The f1rst two are from F. B. Sanborn's Introduction to Ellery. ChannIng's Poems of Sjxty-Five Yeang (Philadelphia: James H. Bentley, 1902), p. $x x x$ and $p_{0} \times x x v 11$; the last two from Van Wyck Brooks, The Flowering of New England, 1815-1865 ([New York]: E. P. Dutton and Company, Incorporated, 1936), p. 284 and p. 297.

$$
\begin{aligned}
& 7 \text { Mor1son, "Edward Channing," p. } 255 . \\
& { }^{8} \text { Ib1d. }
\end{aligned}
$$


Just so Ellery Channing! True enough, this Independent spirit led father and son different ways. Ellery, for example, reacted to his poor family background by being a poor and 1rresponsible famlly man himself, while Edward compensated for his by being very devoted to his own family. St1ll, none can deny that both father and son were intensely individualistic.

Anyone who attempts to describe Edward Channing's personality feels compelled to mention his gruffness. But all agree also that this was just a front for the real Channing. The gruffness showed 1 tself in many ways, but was most frequently evident in association with Channing's cockiness, or, in the eyes of some, snobblishness. In addition to the oft-told story quoted at the head of this chapter, 9 there is one about Channing's comment to a young lady clerk at the Harvard "Co-op" who made the mistake of asking him his name. He puffed up, apparently shocked and Insulted, and directed her emphatically to "Ask anybody!"10

Arthur M. Sohlesinger became Channing's colleague in 1924 and had an offlce near his in Widener Library. He recalled that Channing, "under his gruff exterior regarded me with a paternal eye. Once, Indeed, when he thought my desk poorly lighted, he installed his own floor lamp unt1l I

9 Merle Curt1 thought he remembered that he was the one who asked Channing this question. (Letter to the author, August 2,1966 :) And he may have been, though something similar to the incident quite possibly could have happened many thes.

${ }^{10}$ Interview w1th Paul H. Buck, June 9, 1967, Cambridge, Massachusetts. 
purchased one l1ke 1t." "I discovered that his bark was always worse than his bite," added Schlesinger. Mrs. Schlesinger recalled that the Channings had almost no social life, and that she thought Channing had "a little vanity," but she also emphasized that he was a very kind person, and that even his I1ttle "tartness" was quite attractive: "Not really stinging --sort of lively and satiric, it gave life to the conversation."1l $\mathrm{Mr}$. Robert H. Haynes, who worked in the Harvard library system for many years and came to know Channing quite well, used "exuberance" as a key word in his description of the "Interesting, enigmat1c" personality. He also spoke of Channing's individualism, dry sense of humor, the fact that he was "unapproachable" only in appearance, and of how kind and considerate he was with the library staff. But he remembered several Incldents indicative of what Channing's critics would call his concelt and snobblshness, too. For example, one day, shortly before closing time in the library, Channing was checking out a rather large number of books, perhaps $s 1 x$ or eight. He commented casually to Haynes that he would return them the following morning.

"Professor Channing," sald Haynes, "you don't mean to tell me you're going to read all of those books tonlght?"

"Why not?"

"That's a lot of reading."

${ }^{11}$ Schlesinger, In Retrospect, p. 85; and Interview w1th Mrs. Arthur M. Schlesinger, August 30, 1966, Cambridge, Massachusetts. 
"Not the way I read. Have I ever shown you the way I read?" He proceeded to do so, thumbing through one of the books with little more than a glance at each page, and commenting in essence as he did so, "When you look at a tree, you look at the entire tree. You don't say 'I'm looking at that leaf, I'm looking at that branch, I'm looking at that twig,' etc.-you look at the whole tree. There have only been two people I know of in the history of the world who could read that way-Macauley and Channing." 12

Those who would consider Channing a snob do have some things to which they can point, including, of course, some of the little anecdotes already related. Even more speclfically, there is the recollection of a former assistant of Channing that he was made to walk a step behind the professor when carryIng his book bag for him across Harvard Yard on the way to class, 13 and the question he reportedly once asked when he came across the name Shaw in looking over class admission cards-- "Is this Shaw a Shaw from Watertown or just a Shaw?"14 St11l, those who knew Channing best should be most qualified to

12 Interview with Robert $H$. Haynes, August 24,1966 , Cambriage, Massachusett's' Frederick Merk also recalled Channing's pride in his reading speed. Interview with Frederick Merk, August 22, 1966, Cambridge, Massachusetts。 $16,1966$.

13 Letter to the author from Herbert $w . H i l l$, September

14 A. K. Christian, "Great H1stortans: Edward Channing," p. 5. (Th1s is a 6 -page unpublished manuiscript of a radio address given by Christian on January 10, 1950, and in his possession.) 
judge, and they consistently contend that such Inc1dents do not show the "real" Channing, that he was not even concelted, 15 much less a snob. ${ }^{16}$ Perhaps the words of A. Lawrence Lowe1I, student and long-time friend and associate of Channing, best summarize briefly the essence of "The Great Channing" personal1ty:

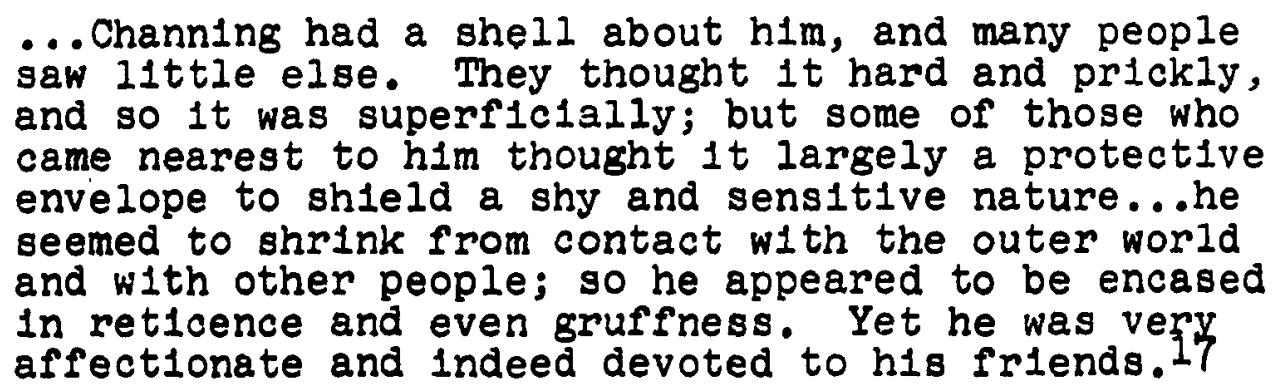

Mention has been made of Channing's almost complete lack of soclal life. H1s only recreation--aslde from travel, of which he did a great deal, primarily in connection with his research--was sa1ling. Th1s love he flrst acquired during h1s Harvard student days, and he never lost 1t. "It was typ1cal of Channing," wrote Mor1son, "that h1s f1rst boat should be the 1deal one for a lone hand, a Rob Roy salling canoe." One acquaintance of Channing remembered how he "would paddle the canoe several miles out to sea and lie there basking, drinking in the beauty of sky and ocean, absorbing the strength

${ }^{15}$ Interv1ew w1th Robert H. Haynes, August 24, 1966, Cambridge, Massachusetts.

${ }^{16}$ Interview with Samuel El10t Morison, June 9, 1967, Cambridge, Massachusetts. Morison stated emphat1caliy that Channing was not a snob: he said that if people were serlous, regardless of who they were, Channing respected them.

17 A. Lawrence Lowell, "Edward Channing," Academy Publ1cation No. 77 of the American Academy of Arts and Letters, New York, 1932, pp. 81-82. 
that comes with sunlight and clean a1r."18 It was also typical of Channing that, as he sald,

One of the first things that I accomplished with the 'Rob Roy' canoe was to disprove to my own satisfaction, but greatly to the discomfort of the sundry descendants of the P1lgrims, the story of the landing of the P1lgrims as given in the textbooks and romances of the t1me.19

H1s love of the sea Channing passed on to his family. "Sa1ling was his joy," recalled one of his deughters, both of whom were taught saling by their rather. It $1 \mathrm{~s}$ st112 in the fam1ly. 20

In Channing' fam1ly l1fe st111 more can be learned of his personality. H1s younger daughter reoulled many thing that help lead to an understanding of the man. Sho, too, recalled the lack of soolal 11fe, saying her parents almost nover went out at night. Channing was rather slow in adjustIng to toohnologloal Innovat1ons: the ram1ly nover owned an

\section{Morison, "Bdward Channing," p. 258, Mortson Peels} that Channing's salling exporlenoe wade him "an exoellent amatour seaman, deopened h1 love of the soe, taught him Mplsoontrol, and proved most userul in his historioal work." (p. 258).

19 Bdward Channing, "Reoolleotions of a H1therto Truthrul Man," P. 17. "And 1t 1s weli asain to state that the Mayrlower on the Iday we oelobrate' was swinging to her anohor In what 1s now Provinoetown Harbor, some thinty miles from PIymouth Rook," he coneludea. (pp. 17-18). In1s was Channing's first contribution in the area of what historians today, oald "dobunking." HIs name appeared in print soverel times in oonneotion with the Plymouth Rook "myth," but h1s statements about $1 \mathrm{t}$ in the History are relatively moderate.

20Interviews with Elizabeth Channing Fuller, August 19, 1966, Chatham, Massachusetts, and w1th Al10e Channing, August. 18, 1966, North Chatham, Massachusetts. Whon the author met one of Channing's grandsons-and his ohildren in the oummer of 1966, they were on the1r way to the ocean for saliling. 
automob1le, a machine wh1ch he abhorred--he contended 1t was cheaper to hire one when necessary than to buy one and hire a chauffeur; they also never had a radio; and they got the1r r1rst telephone about 1900. Chann1ng always walked to work, but he never wore an overcoat or rubbers. Indeed, he took 1ssue with his wife about the children wearing them, holding that their feet would get wet anyway, and they would dry much more quickly w1thout rubbers. Th1s daughter had nothing but praise for Edward Channing as a father. She spoke of the1r "lovely family 11fe" and how he "adored the family." "His own poor famlly background," she concluded, "perhaps caused him to treat us even better--he did everything for us."2l channing mast have allowed his gruff exterlor to show at home sometimes also, however, for when a grandson recalled his boyhood lmage of the old man, he sa1d, "I was soared of $\mathrm{hIm}, "$ and $\mathrm{hlo}$ mother, Channing's daughter, responded, "I was soared of h1m, too." 22 Muoh of what Bdward Channing beoame seems to have been In reaotion againut something in h1s baokground: Honry Cabot

21 Intexviews w1th El1zabeth Channing Ful1er, August 18 and 19, 1966, Ghathat, Massaohusetts. The other daughter, Al10e, placed more emphas 1s upon Channing being so buey and having ilttle time for anything other than his work. (Interview, August 19, 1966, North Chatham, Massachusetts.) The preBent author ventures no explanation for this difforonoc.

\section{The grandson was W1llard P. Fuller, Jr., who was} present at the author's Interview with his mother, Blizabeth Channing Fulier, on August 18, 1966. Another grandson remembered Channing as "a tout, baldish, red-faced old man, who was somewhat gruff and sharp, but who was one to be revered and respeoted."--John Channing Fulier, "Edward Channing: Essays on the Man, The Teacher, and The Writer" (Unpublished senior honors thes1s, W1111ams College, 1943), p. 25. 
Lodge's dogmatism helps explain both his entrance into the historical profession and his open-mindedness as a historian; his poor family background helps explain his own family's baslcally good life together. Just so with his religious views--the lasting 1mpression made on him by the religlous environment of his youth did not make him a "religious man" In the normal sense of that phrase. A grandson analyzed th1s rather well when he sald of Channing:

When he was young, in the famlly of his grandfather, he was obliged to attend the Unitarian Church. Th1s enforcement had the same effect as h1s required plano and dancing lessons-he became antagonistic to formal religion. Consequently in his maturity he kept his church attendance to the barest minimum. 23

The last sentence is something of an exaggeration, however. Though Channing's daughter agreed that he was "not a very rel1g1ous person," she did recall that "he made us go to church and always went w1th us." The Channings, in the tradition of the time, had their own paid-for pew in the church, and their own hymnal with the1r name on 1t. "Father always got fur1ous when someone else got in our pew," sa1d the daughter. The sort of thing he commented on after the service was the minister's hablt of blinking and the ract that President El10t's wife had to poke him constantly to keep nim arake. 24

\footnotetext{
23 Puller, "Edward Channing," p. 26. 24 Interview with Elizabeth Channing Fuller, August 19, 1966, Chatham, Massachusetts.
} 
of Channing's religious bellefs little can be sald with certainty. His only comment was a typically humorous one in the "Recollectiong," where, after commenting on his ancestor, Thomas Dudley, whom he considered "a man of God," he sa1d:

I sometimes wonder what he would have thought of his descendant, William Ellery Channing, Unitarian clergyman, or of the present writer who is even worse, theologically, than h1s great-uncle, if that be possible. 25

The grandson speculated as to whether Channing had a "personal credo," and concluded that 1 t was

... logical to conjecture that he had a working set of bellefs, probably of the simplest sort, for his need was not great. The significant part is that his individuality was the main cause of this lack of formal religion. In his own eyes he was suff1clent unto himself. 26

A daughter was "sure that he gave up going to church after we grew up."27 According to Morlson, 1t was about 1905 when Channing stopped going to church because he needed Sundays to work. 28

If stating that Channing was a Unitarian says littie about his religious phllosophy, it is also true that recordIng that he was a Republican says little about his

\footnotetext{
${ }^{25}$ Channing, "Recoljections," p. 2. 26 Fuller, "Edward Channing," p. 27.

27 Interview with Elizabeth Channing Fulier, August 19,
} 1966, Chatham, Massachusetts.

$$
28 \text { Morison, "Edward Channing," p. } 281 .
$$


political philosophy. Indeed, still less can be said with certainty of Channing's political views than of his religious ones. According to his daughter, he was not active politically; he always voted, but he was too busy to go beyond that. 29 Morlson stated that Channing became a "Jeffersonian liberal" by reaction against Lodge's teaching, and also recalled that Channing once told $h 1 \mathrm{~m}$, "I'm one of those who will vote for the Democrats when the Democrats w11l let me."30 Only a few isolated incldents can be given to clarify further whatever political credo Channing may have had. He strongly disliked Woodrow w1lson, referring to him on at least two different occasions as "congenltally dishonest." Once this was in connection with Wilson's support of the income tax, "which Channing abhorred." The other time was the mornIng after W1lson's re-election to the Presidency in 1916, in connection with his five-volume History of the American People, which, according to Channing, he had written "w1thout having the proper knowledge or research in the fleld."31 According to Arthur M. Schlesinger, Channing reproached him for supportIng the Democratic candidate, Alfred E. Smith, for president

\footnotetext{
${ }^{29}$ Interv1ew w1th Ellzabeth Channing Fuller, August 19, 1966, Chätham, Massachusetts.

${ }^{30}$ Interview with Samuel Eliot Morison, June 9, 1967, Cambridge, Massachusetts.

${ }^{31}$ Letters to the author from Arthur P. Whitaker, July 21, 1966; and Richard L. Morton, JuIy 7, 1966.
} 
In 1928, so Channing doubtless supported the Republican cand1date Herbert Hoover in that contest. 32 To his credit, Channing allowed virtually nothing of whatever partisan views he may have had to show in his historlcal writing--he pralsed or condemned individuals and parties on their merits or demerits, as he saw them.

The same is true of his teaching. In seeing what Channing was like as a teacher, one can discern still more of what he was as a man. Channing's own account of his first formal lecture at Harvard is interesting, and important as well, for 1t tells a great deal of what his teaching methods were to become:

\begin{abstract}
...stuffed with knowledge and dates, I proceeded to the lecture room, walked majestically to the platform, slammed my notes down on the reading desk, turned around,...steeled myself, advanced to the side of the desk so that the class could see that I took no look at my notes, and went ahead, at full speed, for fifty minutes. It was an ordeal, but 1t gave me a feeling of confldence which never deserted me in the nearly haif century of my pedagogical efforts in Harvard University. 33

From that time on, one of Channing's distinguishing characteristics as a teacher was that he used elther no notes, or only as many as he could get onto one small card. Other than that first lecture, Channing, himself, said l1ttle about his teaching. He did write in 1917, half serlously:
\end{abstract}

\footnotetext{
32 Schlesinger, In Retrospect, p. 85 .

${ }^{33}$ Channing, "Recollections," p. 34 .
} 
The humdrum life of a professor is much the same from year to year. Boys look alike to Alma Mater, although to their own maters they seem very different. They are splendid fellows that we have and appreclative of the efforts of yours truly. I glve them American history by the decade. They take $1 t$ in, give some of it to their fathers, remember a little, and forget the rest; but some of them have learned how to read and some have learned a little something as to how to use their brains. Otherwise they have made pleasant and useful acquaintances and have developed their bodies. These are the undergraduates. I have also had a constant stream of graduates, mostly from other pedagogical institutions. I am ambitious to turn out a few ilterary historians, but these graduates persist, for the most part, in wanting to be fitted for teaching jobs in colleges and universities throughout the country. 34

To learn more of what Channing was really like as a teacher, one must turn to the more serious comments of those who observed first-hand. A. Lawrence Lowell felt that Henry Adams' Influence on Channing's teaching was evident in three specific ways: waking students up by shocking their prejudices, giving them topics to study and report upon, and delving into their background to find topics in which they would be likely to have a special interest. 35

The "shocking" usually took the form of "debunking." "In the college comic paper of that day Channing always appears wearing a top hat; and generally bearing a hatchet or some such implement of destruction, almed at the Washington Elm,

34 Harvard College Class of 1878: Secretary's Report, No. VII, 1917, p. 12.

35 Lowe11, "Edward Channing," pp. 74-75. 
or Plymouth Rock, or other popular fetish."36 Even Channing's daughter recalled that her father was known as "the Channing Mouse, because he gnawed at everything." 37 This tra1t is beautifully and humorously satirized in a little volume ent1tled Al1ce's Adventures in Cambridge, by R. C. Evarts, in which the Black Knight shows Allce the slghts of the c1ty. The Black Knight tells Allce he is going to show her an 1conoclast; they find him in Cambridge Common, working with hammer and chisel to carve the word "not" between the words "did" and "take" on a tablet whlch reads "UNDER THIS TREE GENERAL WASHINGTON DID TAKE COMMAND OF THE AMERICAN ARMY JULY 3, 1775." "That's the Channing Mouse," the Black Knight Informs Allce. "He never belleves anything he's told." Before leaving, they are informed that the American army and George Washington are both, Indeed, myths. As they walk away, Allce asks the Black Knlght, "Doesn't he belleve in anything?" He replies, "Nothing but himself." 38

According to Lowell, "The practice of assigning to both graduates and undergraduates topics to be worked up in the library and made the subject of a report began...w1th Henry Adams and was brought to a h1gh state of perfection by

36 Morison, "Edward Channing," p. 269.

37 Interview with El1zabeth Channing Fuller, August 19, 1966, Chatham, Massachusetts.

$38_{R}$. C. Evarts, Al1ce's Adventures in Cambridge (Cambridge: The Harvard Lampoon, 1913), pp. 36-39. 
Channing."39 Lowell sald that Channing as a lecturer was "highly successful, and at times very Impressive。oyet these lectures were delivered in a quiet, discursive tone, without the slightest attempt at oratory。" 10

Morison described Channing's lecturing technique briefly by saying that he "sat down at the podium and conducted a one-sided conversation with his students;"4I and spoke of him more fully:

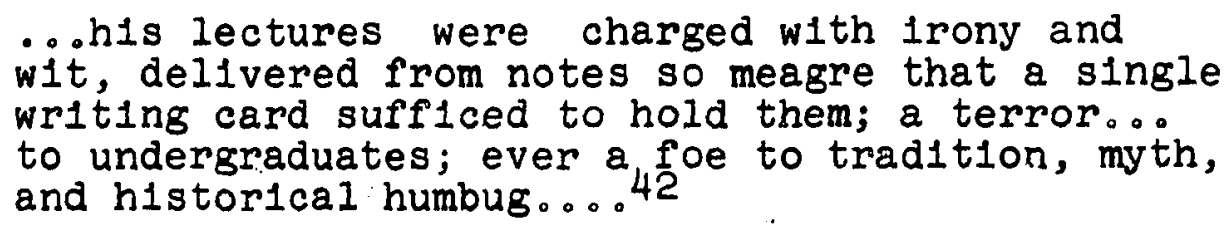

He also recalled that Channing "slapped down the dull, stupid student w1 thout mercy," but was encouraging and helpful to the good student; that he was much more accessible than most professors, never brushing a student off because he was too busy; and concluded that he was an "excellent" teacher. 43

Almost w1 thout exception, Channing's students have spoken highly of him. Typical are these comments: "very fine

$$
\begin{aligned}
& 39_{\text {Lowe11, "Edward Channing," pp. } 75-76 .} \\
& 40_{\text {Ib1d., p. } 77 .} \\
& 41_{\text {Samuel El1ot Mor ison, By Land and By Sea: Essays }}
\end{aligned}
$$
and Addresses (New York: Alfred A. Knopf, 1953), p. 299. ${ }^{42}$ Samuel Ellot Morison, ed., The Development of Harvard University Since the Inauguration of Pres1dent El10t, 18691929 (Cambridge: Harvard Univers1ty Press, 1930), pp. 168-169.

43 Interview with Samuel Ellot Morison, June 9, 1967, Cambridge, Massachusetts. 
lecturer," "very well organized," "great teacher," "one of the best," "a natural-born teacher," "the great enthus1asm wh1ch he aroused in h1s students," "a remarkable undergraduate teacher," and "a very fine teacher. H1s lectures were interestIng and full of remarks that made you think." 44

${ }^{44}$ Interview w1th E. E. Dale, May 27, 1966, Norman, Oklahoma; Interview w1th Hugh $O$. Dav1s, September 22 , 1966 , Tulsa, Okiahoma; Letter to the author from J. C. Russeli, Apr11 17, 1967 (Russell himself was not a student of Channing, but was at Harvard from 1922 to 1926 ); Letter to the author from Edward C. K1rkland, July 18, 1966; Letter to the author from Herbert $w . H 111$, September $26,1966$.

Merle Curt1 was the only one of Channing's former students whose comments in evaluation of his teaching were baslcally oritical. He felt, among other things, that "the lectures were very thin on the substantive side." (Letter to the author, August 2, 1966.)

Several sets of notes taken by students in Channingtaught courses are avaliable in the Harvard University Archlves. However, except for those of Lawrence Shaw Mayo, these are of little value in determining anything about Channing's methodology or the content of his courses. The handwritten Mayo notes f1ll five volumes, and include, in addition to lecture notes, such things as reading assignments, examinations, and class rolls. The two courses covered were general ones in American history. Several things can be 1 mplied from them. In spite of the comments that his lectures were well organized, Channing's hab1t of not using notes seems to have caused him to wander rather freely at times. In a lecture on November 28, 1913, for example, he made blbilographlcal references to Osgood, Andrews, and Greene, discussed whether sever1ty of punishment is a deterrent to crime, benefit of clergy, etc.--with no indication in Mayo's notes as to what the subject really was at the tIme. His lectures were much more personal than the History, apparently, and his dry humor came through more often. "The Salem witches were probably guilty," he once commented. "Isn't anybody guilty if he knows that it is wrong to bewitch, and then goes right about 1t?" The reading assignments show that he did not hesitate to require his own works. And the examinations show that he was Inclined to give essay questions requiring some thought on the student's part which used his History as a take-off point. For example, he would frequently quote an interpretive sentence from 1 and ask the students to support 1 t or refute 1t--It must have taken a brave soul to answer in the negative!--and 
Channing in the seminar should be distinguished from Channing on the rostrum. Though h1s seminar system evolved through the years from emphasis on research to stress on the tralning of teachers, 45 the method did not really vary a great deal. The subject matter, however, moved forward as Channing's work on the H1story advanced. Indeed, one of the few complaints of students about the Channing seminar was the lack of freedom in the selection of a topic. ${ }^{46} \mathrm{st111}$, he was careful to acknowledge by footnote in the H1story the work of any student who had made a real contribution, and thus to confer upon them the honorary degree of E.I.C... "Embalmed in Channing." 47 Most who came out of the seminar felt that 1 t was here, w1th greater opportunity for individual contact with the student, that Channing was at h1s best. One of the most valuable things about this experience was the way he required them to give the1r report to the group from a minimum of notes--just as he gave lectures. As Mor1son sald, "[Albert Bushnell] Hart would cull the promlsing young men and encourage them, and send them to Channing's famous seminary...to be discouraged;

he once asked them to "Compare Channing's analysis of the causes of the American Revolution w1th that of Lecky, or Trevelyan, or F1sher."

45 Fuller, "Edward Channing," p.55. 21, 1966 . ${ }^{46}$ Letter to the author from Arthur P. Wh1taker, July 47 Letters to the author from Merle Curt1, August 2, 1966; and Richard L. Morton, July 7, 1966. 
if they survived that they m1ght do." 48 Among the better known of those who "survived" and went on to the Ph.D. In history in the years while Channing was active at Harvard, 1883-1929, were: E. B. Greene, Carl Russell F1sh, Samuel Eliot Morison, Dexter Perkins, Samuel Flagg Bem1s, Freder1ck Merk, Howard K. Beale, Merle Curt1, Clement Eaton, W. E. B. DuBo1s, Frederick Austin Ogg, Solon J. Buck, C. H. McIlwain, E. E. Dale, Marcus Lee Hansen, Edward C. Klrkland, Arthur P. Whitaker, and Fulmer Mood. A I1st of such "greats" leads one to attempt an overal1 assegsment of Channing's teaching career. Channing himself hinted at the Importance of his years at Harvard when he s81d:

The life of a professor is not interesting reading, as a rule, but in my case my activities have been so commingled with the everlasting reformation of Harvard UnIvers1ty, Including the upsetting of the old administrative systems and the making of an entirely new one, that it has not beeis so pokey as most lawyers would think. 49

It was more spec1f1cally and emphat1cally stated by Morison when he credited Channing and Hart with being

largely responsible for the $h 1$ gh reputation that Harvard enjoys in that the American] branch of h1story.... At the retirements of Hart and Channing, In 1926 and 1929 respectively, it was impossible to take a step in American h1story without stubb1ng one's toe on the1r works, or those of the1r pupils and the 1 pup11s' pup11s.50

48 Mor1son, The Development of Harvand Unfvers1ty, p. 169. 49 Harvard cellege C18s8 of 1878: Secretary' ' Report, No. VIII, Fiftleth Anniversary Report, 1928, p. 49. p. 168 . 50 Mor1son, The Development of Harvard Univers 1 ty, 
The words of A. Lawrence Lowell in tribute to Channing as a teacher are a fitting conclusion:

It was a kand of work that may leave a permanent impression and may develop--as in Channing's case-scholars io become iminent in the next generation, but which 18 often forgotten. Its effects are written in the minds of men, not on pages that are carefully preserved... he made scholars but not a school.51

Channing served as cha1rman of the Department of History and Government in the years 1899 to 1902 . H1s relations with President Charles $W$. Eliot in that period were apparently quite cord1al. A. Lawrence Lowell was chalrman of the department for the next academic year after Channing's occupation of that position; in 1909, this life-long frlend of Channing became President of the unlversity. According to Mor1son, Channing "was on very friendly terms with Pres. Lowell and Dean [Charles H.] Haskins." In general, Morison continued, the department and the college "looked on Channing in those years [after 1910 ] as a valuable but rather 1rascible sobolar and teacher whom they had best not annoy." 52

51 Lowe11, "Edward Channing," pp. 77-79.

52 Letter to the author from Samuel El10t Morison, September 13, 1967.

Folder 40 in'Box 104 of the Charles W. Ellot Papers, Harvard UnIversity Arch1ves, Cambridse, Massachusetts, conta1ns several Letters from Channing to Ellot, mostiy concerned with departmental and/or administrative matters.

K1mbali C. Elkins, Senior Assistant in the Harvard University Archlves, kindiy provided the author with a list of departmental chairmen during Channing's years at Harvard. Prior to 1891, the faculty was not organized into departments. After that date, chalrmen of the Department of History and Roman Law were Ephra1m Emerton (1891-1894) and. Charles Gross (1894-1895). Chalrmen of the Department of H1story and 
Apparently Channing mixed with other members of the faculty rather extensively in the early years, including lunching with them regularly, but he gradually cut this from his schedule, as he did so many other things, to allow him to concentrate on his writing. Especlally interesting, revealing, and Important were his relations with Albert Bushneli Hart, Arthur M.Schlesinger, and Frederick Jackson Turner。

The Channing-Hart relationship is by far the most controvers1al. On the bas1s of some ev1dence, 1t seems that they got along very badly. A notation in unidentipled hand-writing on the back of a program for a dinner which a number of former Channing students gave in his honor at the Cosmos Club in Washington in 1920 referred to Hart as a man "whom Channing hated considerably worse [more?] than all the devils。"53 At the other extreme is some evidence to indicate that their relationshlp was a very close one. Upon hearing of Channing's forthcoming retirement, Hart wrote him: "In half a century of parallel interests and work I have found you falr minded, generous, friendiy as colleague and an honorable rival in

Government were: Charles Gross (1895-1899), Channing (18991902), Lowell (1902-1903), Gross (1903-1907), and Archibald Cary Cool1dge (1907-1910). From 1910 on, the department was a Department of H1story and the chalrmen through 1929 were: Roger B. Merriman (1910-1914), W1111am Scott Ferguson (19141924), Robert Howard Lord (1924-1926), Ferguson (1926-1928), and Arthur M. Schlesinger 1928-1929): (Letter to the author from Elkins, October 4, 1967).

53 The notation is on the copy in the Channing "Quinquennial" folder in the Harvard University Archives. 
some flelds. You have added to the zest of life, you have been a good frlend." 54 Hart was doubtless exaggerating, carried away by the 1mportance of the occasion. The truth, in other words, must lie somewhere in between.

Perhaps the problem was simply that they were completely different personalities-Channing the staid New Englander, Hart the flamboyant Midwesterner. More speclfically, however, Channing apparently was never able to forget that Hart got the job he wanted in 1883. Both men were hired by Harvard that year, but Hart got the American history courses, while Channing had to be the departmental handy-man for many years, moving Into the courses he wanted only as Hart gave them up and moved Into the field of government. Also, Channing probably became "a little jealous of Hart's fame," 55 which was mostly in the earlier period, and took a little too much pride in surpassing Hart as he rose to prominence himself ${ }^{56}$ Both of Channing's

${ }^{54}$ A. B. Hart to Edward Channing, Apri1 14, 1929. This is from a folder of miscellaneous material labeled "Resignat1on" in the possession of Elizabeth Channing Fuller, Chatham, Massachusetts.

55 Interview with Samuel El1ot Morison, June 9, 1967, Cambridge, Massachusetts.

${ }^{56}$ Interview with Paul H. Buck, June 9, 1967, Cambridge, Massachusetts.

Hart was doubtless helped in getting the job by the fact that President Ellot looked favorably upon h1s German education (Ph.D. from Freiburg under von Holst, 1883). Both Morison and Buck agree that the occasion of the hiring was the original source of conflict between Channing and Hart.

Disiliusioned, Channing became an applicant for a position at Ohio State University in 1885, but the appointment went to George $W_{0}$ KnIght, a Mich1gan $P_{0} D_{\circ}$, and Channing stayed on at Harvard. (Buck Interview; and Morison, "Edward Channing," p. 266.) 
daughters, though vague as to 1 ts exact nature, definitely Implied that there was some 111 feeling between the1r father and Hart. 57

W1th some evidence pointing in the direction of hatred and other toward close frlendship, it is impossible to say with certainty exactly what the nature of the Channing Hart relationship was. Most of the facts indicate a middle ground. One can make note of the fact that they cooperated for many years in the conduct of joint seminars, yet should also be aware that the whole purpose of th1s was to meet Henry Adams' 1deal of a seminar conducted by two completely opposite professors $\mathrm{s}_{0} 58$ There is no doubt that Channing delighted in h1s own seminars In taking little pokes at his colleague. Of Hart's voluminous writings he once sald, "Hart loves the smell of printer's ink"; "Hart is st111 unreconstructed," he commented to a student who had spoken of Hart's undue blas against the south; 59 and he reportedly once told a seminar group that "People from Onio [Hart's home state] have muddy brains."60 one might feel that Channing and Hart had to get along falrly well to be able to produce the1r cooperative quide to the Study of American H1story

\section{Interview w1th El1zabeth Channing Fuller, August 18 ,} 1966, Chatham, Massachusetts; and Interview with Alice Channing, August 18, 1966, North Chatham, Massachusetts.

58 Henry Adams, The Education of Henry Adams: An Autoblography (New York: The Modern L1brary, 1931), pp。303-304.

59 Both these incldents are recounted in a letter to the author from Richard I. Morton, July 7, 1966 .

${ }^{60}$ Christian, "Great Historians: Edward Channing," p. 5. 
In 1897; but one also should be aware that they squabbled about such minor things as whose name should come first on the titlepage. 61 Also, on the bottom of a letter from Hart to Channing In 1921, proposing a new edition of the Gulde, elther Channing or his secretary scribbled a note which read, "EC on no acct to have anything further to do with guide."62 one might con. tend that Hart must have regarded Channing highly to have cho sen him to do the volume on Jefferson for his American Nation series; but 1t should be known that Channing consldered the volume a "pot-boller," secondary to his H1story. He undertook it for only two reasonsme money and the fact that he and Hart "must work together。" 63 He greatly resented Hart's "bluepenciling" of his manuscript, ${ }^{64}$ and he wrote to his publisher that he would "never get into a thing of the kind again." 65

${ }^{61}$ Channing to Hart, February 22 and March 5, 1893 , quoted in Lester J. Cappon, "Channing and Hart: Partners in Bibliography," New England Quarterly, XXXIX (September, 1956), p. 328.

Channing did not even want Hart's name to appear as co-author of the Gulde in a list of his other publications on the title-page of his Students' H1story of the United States: (Channing to George P. Brett [President, Macmilian Company], July 7, 1897. Th1s is from the Edward Channing file of the Macmilian Authors Collection in the New York Public Library. Channing Fuller.

62 "Resignation" folder in possession of Elizabeth

63 Channing to Brett, January 21, 1902, Macmillan Collection。

${ }^{64}$ Interview with Samuel Ellot Morison, June 9, 1967, Cambridge, Massachusetts。

${ }^{65}$ Channing to Brett, May 2, 1905, Macmillan Collection. 
And finally, one might emphasize such 1ncidents as when Hart sent Channing a clipping about the two of them with the follow ing note:

$$
\begin{aligned}
& \text { Dear Channing:- } \\
& \text { Fame, bilateral, adjunct, distributive, } \\
& \text { reciprocal, jolnt and several! Please return } \\
& \text { (the cutting, not the fame) Yours } \\
& \text { "And Hart" }
\end{aligned}
$$

Channing's reply was, "Dear Brother Hart, Your letter goes right to my heart."66 or one might stress such incidents as when a $\mathrm{Ph} . \mathrm{D}$. candidate, tired of waiting in the hall while the committee supposedly deliberated on his passage or fallure of the oral examination, approached the door only to hear "the loud volces of Channing and Hart, argulng over something which had nothing to do with his examination."67 In oonclusion, probably all that can be sald safely about the relationghip between Channing and Hart is that "They learned to rub along together falrly well"--68 no more, no less.

Channing's relationsh1p w1th Schlesinger was not controversial, but is still interesting and revealing. Though the Channings and the Schlesingers never became intimate after Schlesinger came to Harvard in 1924 , because of the age difference and Channing's 1solation to work on his H1story, the

66 Th1s exchange $1 \mathrm{~s}$ found in the "Res1gnation" folder a1so. The reply by Channing is actualiy in the form of a note by Channing's secretary at the bottom of Hart's letter. 67 Letter to the author from Jo C. Russe11, Apr11 17, 1967. The candidate was Howard $\mathrm{K}$. Beale. 68 Morison, "Edward Channing," p. 226. 
two men did have a baslcally pleasant association. Schlesinger used to help Channing get set for the summer at his place at Cotult by hauling carloads of books down for hIm. "He seemed to be very fond of my husband," recalled Mrs.Schlesinger. And she struck perhaps the dominant note of the1r relationship when she sald that they were constantly engaged in "a goodhumored repartee about sections."69 schlesinger wrote thus of Channing:

Though delighting to derlde the "crude" Middle West, he expected retorts in kind, which he never falled to get. When he (rightly, of ccurse) jeered at the demagoguery of Mayor Thompson of Ch1cago, I blandiy observed he had evidently forgotten trat "B1g B1II" was a nat1ve of Boston....Again, when he reproached me for supporting the New Yorker AI Sm1th for President in 1928, it was, I explained, because he had at last convinced me of the superiority of any Easterner over any Westerner, only now to find hlm backing Herbert Hoover, a Californian born in Iowa.70

Schles1nger recalled that Freder1ck Jackson Turner helped him.make up his mind in 1924 to go to Harvard rather than to Columbia, where he also recelved an offer, by emphat1cally deny1ng the rampant rumors that "h1s testy Yankee colleague Channing had made I1fe so miserable for this son of a newer and rawer part of the United States that he had ever since regretted leaving wisconsin."7l Channing was supposed

${ }^{69}$ Interv1ew w1th Mrs. Arthur M. Schlesinger, August 30 , 1966, Cambridge, Massachusetts.

${ }^{70}$ Schlesinger, In Retrospect, p. 85 .

$71_{\text {Ib1d. , p. } 79 .}$ 
to have irritated Turner by h1s attitude toward the west. Maybe the rumors were not true, but their persistence should be noted; there was another one which held that Turner left Harvard to retire in 1924 because he was "so tired of Channing's teasing." 72

If the teasing did not bother Turner, he must have been virtually immune. The stories 1llustrative of it are almost endless, and some of them are so strong as to verge on something beyond banter. Morison sald that Channing was "a little snippety about Turner."73 Channing did not have a very high opinion of Turner's frontier thesis; he once remarked to a student that "Turner is a dear fellow but he has no ldea of the value of time. He has never written any big books."74 Probably the best-known of the Channing-Turner storles is the one In wh1ch Channing was supposed to have habitually begun his seminars by removing a mysterious pamphlet from a drawer and brandishing it in front of his students, proclaiming "Here,

72 Interview with Samuel Ellot Morlson, June 9, 1967, Cambridge, Massachusetts. Morison seemed to doubt this story also.

73 Ibid. It is interesting to note that Channing's own grandson dec1ded, after investigating the inter-relationship between Channing, Hart, and Turner, that, "In the last analysis It was probably Edward Channing himself who was the more diff1cult of the three." (Fulier, "Edward Channing," p.71.)

74 Interview with E。 E. Dale, May 27, 1966, Norman, Oklahoma; and E. E. Dale, "Turner--The Man and Teacher," The Un1vers1ty of Kansas C1ty Rev1ew, (Autumn, 1951), p.27. 
gentlemen, is where Turner got his 1deas from," and returning It just as mysteriousiy to the drawer. 75

St11l, there is no surviving evidence to indicate that the relationship between Channing and Turner was nearly so strained as that between Channing and Hart. There is a great deal more evidence-good evidence--to Indicate that they were quite close. One of Channing's daughters recalled that the two men were "very good friends," and that even the two families were friendly and used to visit frequentiy. The other daughter agreed that Channing and Turner were friends, and added that she knew of no conflict at all. A former student of both thought they were "good friends." St111 another source spoke of Channing's "high personal regard" for Turner. And finally, Paul H. Buck felt that any storles hinting at 111 feeling between the two men were "pure embroldery." They "got along very well," he said, and simply enjoyed taking digs at each other. According to Buck, Turner once brought something up in a conversation with Channing about the problems of notetaking. Channing told him, "You ought to do as I do--hire a secretary!" Turner retorted, "I can't; I never wrote a text-book! "76

\section{The Early Writings of Frederick Jackson Turner} (Madison: University of W1sconsin Press, 1938), p. 3.

76 Interview with Elizabeth Channing Fuller, August 18, 1966, Chatham, Massachusetts; Interview with Al1ce Channing, August 18, 1966, North Chatham, Massachusetts; Interv1ew with E. E. Dale, May 27, 1966, Norman, Oklahoma; Glenn Weaver, "Edward Channing: A L1terary B1ography," Soc1al Studies, IIV (March, 1963), p. 85; Interview w1th Paul H. Buck, June 9, 1967, Cambridge, Massachusetts. 
It was, indeed, Important for Edward Channing in many ways that he "wrote a textbook." Financlally, the Students' History of the United States allowed him not only to hire a secretary, but to support himself and his family while he concentrated on his mult1-volume H1story. And the reputation whlch the text and other of his publications began to make for him after the turn of the century enabled him to cut down on the amount of his teaching at Harvard and to concentrate only on those areas which would be of specific utility in his writIng. He had taught everything from Medieval and Modern European History to American Colonial H1story, from the H1story of England during the Tudor and Stuart Periods to the History of American Institutions, and from European History during the $17_{\text {th }}$ Century and the First Half of the 18th to seminars in United States history since 1865. But he regularly had off half the year after 1919,77 and probably his two best-known courses were American Colonial History and his seminars. Channing's comment to Turner about hiring a secretary hints at something else of importance--the role which his secretary played in his research and writing. The secretary was Miss Eva G. Moore, and her role was an important one indeed. Channing "1nherited" her from Thomas Wentworth H1gginson. As Higinson grew old, he did not use her so often, so she began to work part-time for Channing; when:Higginson died in 1911 ,

\footnotetext{
77 Harvard College Catalogs, 1883-1913; Harvard Un1versity Catalogs, 1913-1929.
} 
Channing employed her full-t1me, and she was w1th him the rest of his life. She was very devoted to him, and apparentig he to her; he always called her simply "Eva G."78 A small folder of letters which he wrote to her st11l survives, and shows that their relationship was a very close one. He commented to her about his family, about her own tonsllectomy, and about her problems with the dentist. The last few years of his life he relied on her increasingly, not only for substantive help in his research and writing, but for miscellaneous personal favors as well, usually financial in nature--paying a b1ll, checking on an insurance pol1cy, etc. ${ }^{79}$ She frequently came to Cotult to a1d h1m in his work in the summer, and even went abroad with the family on one occasion.

As already Indicated, Miss Moore played an Important part in Channing's research and writing. Much of his research was done in the extensive materials avaliable in the Harvard Library. Indeed, some critics have said an exorbltant amount of 1t was. And apparently much of the research that was done there Involved Channing simply taking down a reference to something he had found, often on unused pages which he tore from students' examination books, and having "Eva a." go get

78 Interview with Elizabeth Channing Fuller, August 18, 1966, Chatham, Massachusetts.

${ }^{79}$ Channing Correspondence, 1884-1930, Houghton I1brary, Harvard Univers1ty, Cambridge, Massachusetts. Th1s folder contalns twenty-nine hand-written letters from Channing to M1ss Moore spanning the years 1904 to 1930 , as well as a few other m1scellaneous 1 tems. 
1t for him when he came to the point in his writing that he needed 1 t. 80

M18s Moore was perhaps even more 1mportant a part of Channing's writing method than of his research technique. All the writing Channing did in long-hand whlle working on his Students' H1story gave him a permanent case of writer's cramp; and he could not compose at the typewriter. Thus, h1s method, according to Miss Moore herself, was to put his notes aside and simply walk about the room for two or three hours at a time dictating to her at the typewriter, where she typed the narrative triple-spaced. They then re-read and re-wrote the manuscript several times, inserted citations, verified all facts and quotations, and finally, read it aloud "to get the swing and rhythm of the words and sentences。" 81

A discussion of Channing as a writer would not be complete without some indication as to the nature of the relationship between him and his publisher. With the exception of the two editions of the gulde, the Jefferson volume in Hart's series, and the little 1765-1865 volume in the Cambridge serles,

\footnotetext{
${ }^{80}$ Interview w1th Paul H. Buck, June 9, 1967, Cambridge, Massachusetts.

81Mor1son, "Edward Channing," p. 274 ; and Ralph Ray Fahrney, "Edward Channing," in Wililam T. Hutchinson, ed., The Marcus W. Jernegan Essays in American Historlography (Chicago: The University of Chicago Press, 1937), p. 309. Channing and Miss Moore apparentiy 1mproved their ab111ty to work together as the years went by Channing wrote to Brett in 1922 that he and Miss Moore had "worked together for twenty years. When I dictate to her at the typewriter threequarters of what she puts down goes on to the printed page." (Channing to Brett, September 16, 1922, Macmilian Collection.)
} 
all of Channing's major works were published by the Macmlilan Company. In general, his relations w1th the company were conducted through 1ts president, George P. Brett, and were very cordial. Channing, in a letter to Brett in 1921, spoke of "the long and pleasant relations--and profitable--that one author has had with his publisher." 82 on one occasion when Channing's correspondence made 1 t evident he was upset with the company--he complained rather strongly about some minor m1stakes in advertising bis books--he very shortly thereafter. wrote:

I have been--and am--very sorry that I wrote you in so ferocious a strain.... I was "peeved" and have regretted ever since that I must have caused you annoyance and added to your altogether too great troubles in these days of unrest. 83

Channing and Brett even became rather close frlends, apparently, as the years went on. They wrote to each other of their families, and in the1r later years, of their mutual interest in trees. "I, too, have some pines," wrote Channing; "I understand the 'tree desire' is one of the marks of approaching middie 21re." 84 Each nearly always found time for a brief

82 Channing to George P. Brett, February 1, 1921 , Macmilian Collection. An excellent brief sketch of Brett is Freder10 O. Melcher, "George P. Brett," D1ct1onary of American Blography, XXII, pp. 59-60.

83 Ib1d., December 19, 1919. The "unrest" must have referred to the problems of the company in the First World War.

84 Ib1d., July 6, 1923. 
visit when in the other's c1ty. Brett usually sent Channing a glft of books on special occasions, such as Christmas and when Channing was preparing for one of his frequent research trips abroad. And they even exchanged pictures.

Th1s, then, is something of what the man Edward Channing--"The Great Channing"--was like。 His reputation, of course, rests, and will always rest, on h1s "Great Work"-o the six-volume H1story of the United States. 
I have undertaken a new study of the history of the United States from the discovery of America to the close of the nineteenth century. In treating the subject, the word "history" is understood in its larger sense as denoting not merely the annals of the past, but as describing the development of the Amer1can people from the inception of the colonizing enterprises which resulted in the founding of the thirteen original states and the formation of the Federal Union. The growth of the nation will, therefore, be treated as one continuous development from the political, m11tary, inst1tutional, industrial, and social points of view.--Edward Channing, A History of the United States, Volume I: The Planting of a Nat1on in the New World, $1000-1660$ (New York: The Macm111an Company, 1905), pp。v-v11。 
THE PLANTING OF A NATION IN THE NEW WORLD

The appearance of a h1story by a master hand ought to be regarded as a great event in the 11 fe of a nation. Scholars have long anticipated the appearance of Mr. Channing's work. His speclal studies appearing in various sclentific publications and his academic work in Harvard University have given assur. ance that the ripe product of his historical work would be a worthy contribution. The first volume fulfils [ 10$]$ every expectation. The scholarship easliy surpasses that in any other undertaking of the kind, and the clear, pleasing and simple style makes the book eminently readable. If the 11terary flavor found in some popular historles is lacking, there is ample compensation in the depth of knowledge and the plain-spoken truth. 1

Once Edward Channing made a definite decision to write an extended history of the United States, his whole I1fe was built around that project. During the teaching year at Harvard, he ordinarily spent mornings teaching, afternoons on the History, and evenings in preparation for the next day's classes. 2 During the summer, the areat. Work normally ocoupled both mornings and afternoons, but the evenings were spent in the reading of novels and 11 ght literature for relaxation.

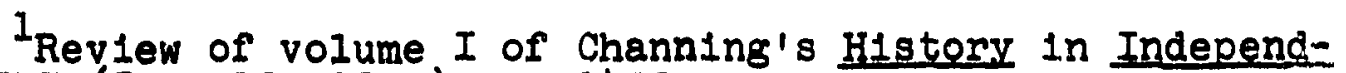
ent, LVIII (June 19, 1905), p。1479.

${ }^{2}$ John Channing Fuller, "Edward Channing: "Essays on The Man, The Teacher, and The Writer" (Unpublished senior honors thes1s, W1111ams College, 1943), pp。43-45. As already noted, the teaching was normally restricted to a half-year after the First World War to allow full time for research and writing. 
After 1900, these summers were spent at the Channing summer home on Grand Island, just of fotult on the south shore of Cape Cod. Before that, the Channings had owned a cottage at Nantucket, but had left it because of the increasing number of tourists there, and purchased the $s 1 x$ or seven isolated acres at cotult。 ${ }^{3}$ The acquisition was partially financed by a $\$ 1,000$ royalty advance on volume I from Channing's publisher, Macmillan. He was very proud of the place, writing shortly after acquiring it to Macmillan's president, George P. Brett, "Th1s is about the best place that I have yet discovered," and asking him to come there for a visit. 4 It prov1ded h1m a quiet place to work and an opportunity to engage in his one pastime, sailing. 5

3 Interview with Elizabeth Channing Fuller, August 19, 1966, Chatham, Massachusetts.

${ }^{4}$ Channing to Brett, May 23 and 25, 1904, and no date, Edward Channing File, Macmilian Authors Collection, New York Publ1c Library. (The undated letter seems to have been written in July, 1905, and is thus placed chronologicaliy in the collection.)

${ }^{5}$ Channing called his place No1sy Point. An explanaw tion of that, and a humorous anecdote as well, is related by the blographer of Harvard Prestdent (1909-1933) A。 Lawrence Lowell. Having commented on Channing's debunking inclination, this author went on: "Strangely enough, Channing was very insistent that his house stood on 'Nolsy Point,' where, the story ran, Hannah Screechum had been killed by Captain Kidd and buried with pirate treasure to guard it by her cries. Lowell delighted in persuading a visitor to ask Channing for the location of Nolsy Point and to add over the historian's loud protest that he had always supposed it was up the narrows." Henry Aaron Yeomans, Abbott Lawrence Lowe11, 18561943 (Cambridge: Harvard University Press, 1948), p。390。 Lowe11 and Channing had been boyhood frlends. The 1 ro houses at Cotuit were near each other, and their families visited 
It has been stated that Channing decided even as early as his undergraduate days at Harvard to write an extensive United States history based on original sources. But the earliest evidence that such a project had taken on definlte shape in his mind dates to 1899. At that time he wrote to James Ford Rhodes thanking him for the gift of a copy of his latest vol ume, then went on:

I wish that I had something to send you in return. Six years from now I may have a small offering in the shape of the first two volumes of my History of the United States. This great (?) work w1ll ultimately-uif I live-consist of from six to eight volumes and will be a continuous narrative of our history from the voyage of Leif Ericson [ sic] $]$ in the year 1000 to the year 1900。 But the first five hundred years will not give me much trouble. 6

He went on to describe the work in more detail, giving special emphasis to his plans for maps and blbllography. The accuracy of his proposals at that early date are rather surprising. Except for the fact that he apparently intended to have the first two volumes ready at once, even his date of publication was correct--volume I came out in 1905.

and salled together (Interview with Ellzabeth Channing Fuller, August 18, 1966, Chatham, Massachusetts.) According to Morison, Channing, James Hardy Ropes, and others in the area in the summer, were sometimes referred to as the "cotu1t Cabinet." The story was that they could get President Lowell out on the water and get him to agree to anything. (Interview with Samuel Eliot Morison, June 9, 1967, Cambridge, Massachusetts.

${ }^{6}$ Channing to Rhodes, October 18, 1899, James Ford Rhodes Papers, Massachusetts H1storical Soclety, Boston. Chan ning had mentioned the project to Brett at least as early as February of that year. He recalled in his autoblography that as of 1896 he had already "long wlshed to undertake a large and formal work" on United States history " (Edward Channing, "Recollections of a Hitherto Truthful Man," p.38.) 
It is interesting to trace Channing's progress on the work in his correspondence with Brett. He first outlined his plan to the company in a letter of February, 1899; the reception was favorable--"I am glad that you like the plan," wrote Channing--for the agreement was signed later that very month。7

In the letter to Rhodes, Channing was not quite conf1. dent enough to refer to h1s proposed study as "the Great Work"; by 1902 , he was, for he wrote to Brett that he was working for awhile on the Jefferson volume for the Hart serles and his beginner's history since he was "tired of the great Work" 8 From that point on, he almost always referred to the History in that manner, and so did his students.9 Indeed, Channing's confidence in the fate of his volume is one of the strongest 1mpressions one gets from his correspondence with Brett. In the summer of 1903 he wrote from cotult that he would be in Cambridge the following winter, "hard at work on that great and glorlous work from which I really and truly expect some reputation and reward," and concluded that "If it turns out to be what 1t gives promise of being it w11l bring in to you some pennies--at least that is the way the thing looks to me."

7 Channing to Brett, February 4, 9, and 17, 1899, Macmillan Collection.

8 Ib1d., May 9, 1902.

9Samuel El1ot Morison, "Edward Channing: A Memo1r," Proceedings of' the Massachusetts H1storical Society, IXIV (October, 1930-June, 1932), p. 273。 
By October he was at work on his final draft. By September of 1904 it was "almost ready," and two months later he had declded on the title, "The Planting of a Nation in the New World." Shortly before publication he enthuslastically stated that the volume was "likely to supply a part of a 'long-felt want' so far as serious students and teachers of Colonial history in the colleges and Normal schools are concerned." And Just after publication he expressed pleasure with at least the appearance of the book, thank1ng Brett for Its "attractive form," and referring to it as "one of the handsomest pieces of book-making which I have seen."10

Though the review quoted at the head of this chapter was a bit more unqualified in its praise than most, the work did not recelve a single review generaliy orltical in tone. This first volume covered the years 1000-1660. It included, therefore, those first flve hundred years which Channing predicted would not give him much trouble. And he was right-w 1t took him only about forty pages of the 537 in the volume to get into the sixteenth century. There is virtually nothing of the "European background" one ordinarliy gets in the beginning of any study of American h1story. Channing must have felt he had nothing to contribute here, for this was often what determined h1s apportionment of space. There is some

${ }^{10}$ Channing to Brett, July 5 and October 22, 1903; September 16, November 21, and December 3, 1904; and Apr11 14, 1905, Macmillan Collection. 
specifically English background, but this is spread throughout the volume in connection with its appropriate New World subject-for example, the discussion of local institutions in England in the final chapter.

Typically, once he had the preface out of the way, 11 Channing began his narrative in a serlous, business-like manner. His first sentence does not really sound like a first sentence: "Religious enthusiasm, human affection, the pursuit of gain--these three motives account for the peopling of America by men of European stock and Christian fa1th."12 It was also typlcal of Channing that he was deeply involved in an attempt to work out a historical problem before he had finished the first page of the narrative. This was the discovery of the New World by Leif Ericsson. Channing's conclusion, after sifting all the evidence avallable to him at the time, was that Ericsson had indeed made the discovery, but that it had little significance:

The whole matter of the Vinland voyages is one of those curlous academic puzzles which are chief'ly interesting on account of the absurd theorles that have clustered around them. The history of America would have been preclsely what it has been if Lelf Ericsson had never been born and if no Northman had ever steered his knorr west of Iceland.13

11 Portions of the preface are reproduced on the t1tlepage of this second part; it W1II be discussed in Chapter XI.

12 Edward Channing, A History of the United States. Volume I: The Planting of a Nation in the New World, 1000-1660 (New York: The Macmilian Company, 1905), po 1。 Hereinafter referred to simply as History, followed by volume number and page. ${ }^{13}$ Ibid., pp. 1-6. 
In the early pages of this opening volume of the areat Work, Channing developed st111 other hablts which were to become outstanding oharacterist10s of the set as a whole. The Interest in naval history, whioh is evident throughout, shows up for the flrst time on page o1x, in a footnote disoussing the types of sh1ps used by the Northmen. The delight in destroying myths comes out in a small way in Channing's treatment of the rolationship between Ohristopher Columbus and Martin Boha1m. Referring to the possibility that Columbus may have been Inriuenoed by Bohaim and his slobe, Ohanning states that the slobe was not completed unt1l after Columbus had already left on his voyage, and conoludes:

of course Columbus could not have seen this globe before he left Palos in August, 1492 , nor 1 s there the silghtest reason to suppose that he over saw 1t. Indeed, there 1s no evidenoe to whow that Columbus and Bohaim over mot. It is ploawant to think of thom as making gabes and oharts togethor and talkine about the varlous routes to Ind $1 \mathrm{a}$, but these thouchts are oonjeotures, pure and dimple. 14

Channing' geographioal Interent and knowlodge is apparant throughout his ooverage of the age of exploration and disoovery. It does seem a bit atrange, however, that he Inoluded nothing in the way of a "goosraph10 wettine for Amori-

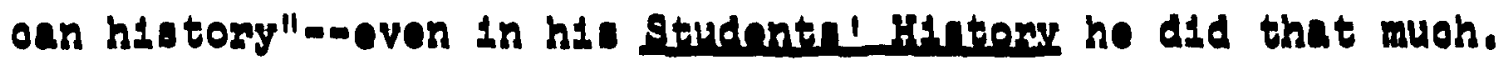

The rootnotes and end-or-ohaptor bibliograph10al oommonts, Imply entstied "Notes," oamo to be Looked upon as one

$$
14 \text { Intd.. p. } 22 .
$$


of the most valuable features of Channing's work. In the latter, he ordimarily concentrated on controversial subjects, evaluated the sources, and sometimes made suggestions for further research.

The Channing literary style, for which he was so widely criticized, also is apparent from the very beginning. It certainly lacks polish all the way through; and yet it is completely clear and readable. Two specific problems, both perhaps minor, and yet irritating, which continualiy occur, are bad paragraphing and use of the phrase "It fell out..." Though his paragraphing seems to have become worse rather than better as the Great Work proceeded-- in the sixth volume one sometimes gets the impression that Channing must have consldered paragraphs a necessary ev11, to be started and ended without consideration of what was being sald--1t was bad enough even in volume I. An example of a paragraph which obviously should have been divided is on page 465. Involved in the commercial problems of New Netherland, the reader is suddenly shocked to find the statement that "Adriaen van der Donck was one of the most interesting of the Dutch emigrants to New Netherland." and from that point on the paragraph is about Mr. van der Donck! An example of a paragraph which 1s obvlously too long 1s the one which extends from page 467 to 470 . The phrase, "It fell out," is used for the first time in the preface, though there 1t takes the present tense. In volume I it 1s used at least sixteen times. Channing repeated it where he 
could have sald "resulted," "developed," "happened," "occured," or a dozen other things; surely it would have been better if he had utilized some of these part of the time. 15

The last of those Channing characteristics which come into play early in the History--and this one much more pleasant to comment upon--is the remarkable dry sense of humor. Three examples will suffice-all from the first chapter! Noting that Bartholomew Dia.z had originally named the southern tip of Africa the Cape of Storms because of his encounter with a "furious northerly gale" in the region in 1486, Channing continued: "King John of Portugal, with a truer insight--and less personal recollection--renamed it the Cape of Good Hope." Evaluating Queen Isabella of Spain, he said: "It is impossible to study Isabella's career at all carefully and not be impressed with her great capacity as a ruler of men including Ferdinand." After covering thoroughly the problem of deciding whlch island it was that Columbus named San Salvador, Channing speculated: "Our difficulty in 1dentifying San Salvador with any known island, however, is small when compared with Columbus' difficulty in identifying it with any land described by Marco Polo and the other narrators of the wonders of the East." 16

15The phrase is used on the following pages, In1d.: pp. $v 11,49,77,128,257,268,367,380,407,421,473, \frac{194}{4}$ 519, 521, and 534. (These are the ones noted by the present author; there may be others.)

16 Ib1d. pp.11, 19, and 23. 
Thus far anything of the content of The Planting of a Nation in the New World wh1ch has come forth has been merely 1llustrative of characteristics of Edward Channing as a historical writer. At this point it should prove useful to give a brief summary of the volume. This will be followed by touching upon several additional highlights, and, finally, by a survey of the way it was recelved by reviewers.

After h1s coverage of the age of exploration and discovery, Channing moved into the background of English settlement. H1s treatment of the founding and early development of the British North American colonies emphasized, of course, Virginia and Massachusetts. French, Span1sh, Dutch, and Swedish colonial enterprises all recelved their due. The final two chapters covered "The Perlod of the Puritan Supremacy, 1650-1660," and what the colonies were l1ke at the t1me of the Stuart Restoration of 1660 .

Relatively few historical figures recelved pralse from the pen of Edward Channing. Among those who did, in the period of American history before actual colonization, were Columbus ("...since the day when Alaric showed the road to the spo1l of Imperial Rome, no man has done more to change the course of human history...."), De Soto ("the most dramat1c figure in the story of Florlda") and his men ("surely one must award to these men, cruel and mercliess though they were, a meed of praise for the1r constancy, courage, and devotion"), Champlain ("Of the earlier French explorers, fur traders, and colonists 
none showed more indomitable perserverance..."), and Hawkins and Drake (respect1vely "one of the greatest of seamen of his day" and "the greatest sea fighter and plunderer of his day"). 17 Interestingly, 1t was with Channing's treatment of the age of exploration, and particularly Spanish activities that more reviewers found fault than with any other single thing in this first volume. Edward Gaylord Bourne, an authority on Spanish activities in the New World, might have been expected to concentrate his review on that topic, and Indeed he did. He spent two pages in the American Historical Review discussing "errata or debatable polnts" in Channing's coverage of the subject. Two other reviewers considered Channing's treatment of Spain and 1ts explorers too "severe" or at least unsympathet1c. 18

Channing's account of the Armada is both interesting and important. It proves that he could write very well at times; It indicates once again his interest in and skill in dealing w1th naval affalrs; and it reveals what he considered to be the causes and signiflcance of the Spanish-British conflict. Commerclal factors were most important in the rlvalry, according to Channing: "The religlous difference between the

${ }^{17}$ Ib1d., pp. $25,67,72,100$, and 116 。

18 Reviews: E. G. Bourne, American Historical Review, XI (January, 1906), pp. 392-393; Independent, LVIII (June 19, 1905), P. 1479; and C. H. Van Tyne, Annals of the Amerloan Academy of Political and Soclal Science, XXVI (September, 1905), p. 422. 
two peoples was entirely secondary." Secondary also was

Philip II's pretension to the English throne. Here is Chan ning's description of the climax of this rivalyy:

Fortunately for England, in this last half century of growing estrangement and hatred, the Spaniards had not progressed in the art of maritime warfare, while Englishmen had broken loose from the traditions of the past and had evolved a new art of war applicable in the rough waters which washed the coasts of the British Isles. They invented a broadside fighting ship, placed on board of her the heaviest and best ordnance then known, and supplied her with crews drawn almost entirely from the seafaring population of the coast. A fleet of fifty ships of this kind encountered a fleet of sixty-two Spanish vessels built on the lines of the Mediterranean sea fighter and designed for hand-to hand conflict in still water. There could be only one result, and the fallure of the Spanish Armada was scarcely douhtful after the fleets had been one day in contact. Led by Drake in the Revenge, the Engl1sh line of battle swept to windward by the end of the Armada, sending broadsides into the windwardmost Spanish ships, to which no effective reply could be made. So went on the merry dance up Channel unt11 the nelghboring shore of France prevented the English from keeping the weather gauge. Fire ships, heavy winds, and strong currents drove the Spaniards through the Straits of Dover in grave disorder. Then came the seaman's opportunity. Round and round the disordered fleet the English vessels salled, pouring broadside after broadside into the helpless Armada unt1l the gunners on the Spanish shlps fled from their pleces and groveled on the decks. Only a sudden squall prevented Gravelines from being an earlier Santiago. Northward, the Invincible Armada fled and returned to Spain by way of Scotland and Ireland, every now and then dropping a vessel in the hungry sea or on the desolate shore.19

And here are his ldeas of the slgniflcance thereof:

${ }^{19}$ H1 story, I, pp。132-133。 
The year 1588...was one of the most memorable years in the history of the English race. For the United States it was more than memorable, it was v1tal. The defeat of the Spanish Armada accomplished the destruction of the morale of Spanish seamen; and that made possible the founding of Virginia, New England, New Netherland, and New Sweden on the Atlantic seashore of North America; from these in course of time developed the American nation. 20

When he described the reigns of Queen Ellzabeth and King James I, Channing waxed eloquent, and also sald a great deal of Importance about Engl1sh h1story and the background for colonial history:

The reigns of El1zabeth Tudor [1558-1603] and James Stuart [1603-1625] ...mark in English history the transition from medieval to modern times.... The Tudor monarchy was essentlally feudal, while the England of Charles I [1625-1649] was as essentially modern. The world was rapidiy changing; this silent revolution took place in England earlier than elsewhere. The causes were many: the keen religlous excitement of the preceding half century, the wave of 1mperialism which swept over the English race, and the reorganization of domestic economy which the religious disturbances and the intercourse with Eastern countries brought about. To this revolution Elizabeth and James powerfuliy contributed through the defects of their qualities: Elizabeth by her strength prevented reform; James by h1s foolish cunning made certain that the process of reorganization which was inev1 table would, nevertheless, not be easy.21

Continuing st1ll further with Elizabeth, Channing sa1d she doubtless possessed "unerring political foresight and Indomitable will," but lacked "the finer qualities of humanity."

$$
\begin{aligned}
& 20_{\text {Ib1d., p. }} 130 . \\
& 21_{\text {Ib1d., pp. } 137-138 .}
\end{aligned}
$$


The English people only bore with her and her opposition to reform "because, in the first place, they respected her, and In the second place, it was quite certain that she could not Iive forever. After her would come the deluge." of the sovereign who Inher1ted that deluge, James I, Channing concluded that he "lacked personal dignity and pol1t1cal wisdom," and, most devastating of all, that he "turned out to be one of those curlosities whom the laws of inheritance occaslonally bring to the notice of mankind."

W1thout thought, he involved himself in dispute after dispute with the various religious and clvil elements which were pressing forward for changes in Church and State...he solddifled against h1s son the most active and aggressive elements in the English population.22

Among those elements were, of course, some of the Individuals who became 1nvolved in the flrst successful attempts at English colonization in North America.

After an excelient description of the disrupted economic conditions in England which also helped lead to an interest in the establishment of colonies, Channing began his narrative of the history of the first permanent English settlement at Jamestown--a thoroughly economlcally-motivated venture, in h1s view. 23 Channing halled these earliest settiers of Virginia as "the first heroes of American history, "24

22 Ib1d., pp. 138-140.

23 Ib1d., pp. 146-149, 155.

24 IbIg., p. 170 . 
and he recognized the importance of the charter which made the colony possible. However, he felt compelled to be critical wherever possible. He devoted a lengthy footnote to an attack on the South's favorite myth of the colonial period: that the settlers of Virginia and New England were markedly different In motivation and make-up, that the former were "Cavaliers" and thus superior to the "Puritans." "No such characterization is possible," he concluded. 25 Channing could think of no praise for Virginia's traditional hero Captain John Smith, and emphasized "the utter unreliability of Smith's account [of Jamestown's early history] entlrely apart from the Pocahontas story." 26

Trying too hard to emphasize the significance of the Virginia Charter, Channing made contradictory statements about 1t. In one place he sald the "most extraordinary thing" about it was "the bold and barefaced cla1m which James Stuart made to a large part of the New World only two years after the signIng of the treaty of London," and only three pages later he contended that it was "even more memorable for 1ts constitutional declarations than it was for 1ts assertion of England's clalm to a share of the New World." What he referred to in this latter statement was the so-called "rights of Englishmen" clause, which stated that the colonists and the1r posterity

$$
\begin{aligned}
& 25_{\text {Ib1d., pp. 145-146. }} \\
& 26_{\text {Ib1d., p. } 174 .}
\end{aligned}
$$


should "have and enjuy all 11bert1es, franchises, and immun1ties within any of our other dominions, to all intents and purposes as if they had been ablding and born within this our realm of England or any other of our sald dominions." Though Channing pointed out that this was really of slight significance in maintaining the rights of English subjects, since these rights were "not subject to the king's fancy" and any Englishman had them anyway "so long as he settled on land clalmed by England and acknowledged alleglance to the English crown," he did acknowledge that this clause nevertheless "marked an epoch in colonization":

Permanent settlements, which in time were to grow Into a great nation, were to be made under its guarantees. The success of the new movement was to depend largely on the proposition that colonists had the same rlghts as home-dwellers-a fact that marks off English colonization from all other colonization, anclent and modern.27

Channing's account of the history of the colony that developed under th1s charter 18 actually quite good--desplte his grandson's complaint that one of the "drawbacks" of the volume was the "great complexity in the unfolding of the political organization of the Virginia colony."28 Perhaps his

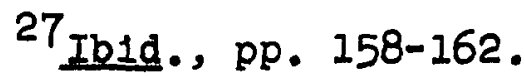

28 Fuller, "Edward Channing," p. I11. The other "drawback" noted by the grandson was not. too logical elther; he doubted "the relevancy to United States history of such a chapter as 'The English Seanan'." (The chapter was actualiy entitled "The English Seamen.") 
visit to the site of Jamestown ${ }^{29}$ added to h1s description of the settlement and 1ts environs--though it could not have helped h1s vivid account of the 1609-1610 "Starving Time:"

The starving settlers, like men on a wreck at sea, dogged the steps of the dying that they might fill their hungry bellies with the flesh of their dead comrades--some of them dug up the bodies of dead Indians and fed on the putrid flesh. 30

The story of tobacco and its significance in the history of Virginia comes out well here. Channing "doubted if the James River colony would have long continued had it not been for the discovery of how to grow tobacco with profit." When, in 1616, a consignment of tobacco from John Rolfe's plantation was sold at a good price in London, "the permanence of English colonization in America was assured."31

Channing freely acknowledged the first Virginia assembly in 1619 as being "of first importance in our annals; it was, Indeed, the 'mother' of the American representative legislature." 32

The dissolution of the Virginia Company in 1624 Channing viewed as "beneficial to all concerned";

${ }^{29}$ Edward Channing, "Remarks on a recent v1s1t to Jamestown and other historical places in Virginia," Proceedings of the Massachusetts H1storical Soc1ety, Second Serles, XIV (19001901), p. 175 .

30 H1story, I, pp. 180-181.

$31_{\text {Ib1d. }}$ pp. 187-188.

32 Ib1. ., p. 202. 
for that corporation was insolvent in 1624 and whatever further exertions $1 \mathrm{t} \mathrm{m} 1 \mathrm{ght}$ have made would have been in the nature of recouplng its members for past expenditures. James died in 1625, and h1s son, Charles I, Immediately became involved in those financial and religlous controversies which led to the Petition of Right, the martyrdom of Sir John Eliot, the meeting of the Long Parllament, the battle of Naseby, and the scaffold in front of whitehall. Virginla and the other colonies were left to develop in the 1r own way, w1th slight interferences from the king and the royal officials.33

Channing polnted out that the population of Virginia increased flve-fold in the ten years after 1624, from 1,000 to 5,000, and concluded that the story of the colony in the fifteen years following the dissolution was "one of slowly growing contentment and prosper1ty."34 In the later years of Virginia's history in this period, S1r William Berkeley, governor from 1641 to 1653 and again from 1658 to 1677, was, of course, singled out by Channing for extensive treatment. Channing considered him "a masterful man," and emphasized the absoluteness of his power, especialiy in his later years. 35

Mention of Channing's sweepling generalizations as to the significance of the Virginia Charter leads to a discussion of a few of the other characteristics and threads which he developed in this first volume. For one of those characterist1cs was, beyond a doubt, overstatement. This is rather

$$
\begin{aligned}
& 33 \text { Ib1d., p. } 225 . \\
& 34 \text { Ib1d., pp. } 226-227 . \\
& 35 \text { Ib1d., pp. } 230 \text { and } 234 \text {. }
\end{aligned}
$$


paradoxical, for most of Channing's narrative is just narram tive, with a minimal amount of interpretation and/or evaluat1on. But when he did decide to evaluate, he did it strongly. Surely it was not true, even in 1905, that "Probably no single event in our history has aroused sharper controversy than the voyage of Verrazano in 1524." And was it really completely accurate to speak of the Anglo-French struggle for supremacy In North Amer1ca as "the serles of wars and massacres which form the most dreary and heartrending tale of woe in our annals"? Th1s tendency got Channing 1nto trouble in a way other than contradicting himself, too, and that was the making of such a sweepling statement which was ne1ther preceded nor followed by adequate facts to support 1t. The first sentence of the book, already once quoted, is a good example: "Religlous enthuslasm, human affection, the pursult of galn--these three motives account for the peopling of America by men of European stock and Christian falth." "Did those three really cover all the motives for colonization? And, whether they did or not, d1d they not at least deserve a little clarification and justification before plunging into an account of the activities of Leif Ericsson? And finally, a similar example Is found in this statement:" "Fish and furs, and the hope of silks and splces, drew men to the barren shores of North Amer1ca."36 Not only is this another example of a statement" 90.

${ }^{36}$ The four quotations are from Ib1d., pp.91, 108, 1, 
which is not followed by adequate explanation, but it and the opening sentence, when compared, provide st1l1 another case of Channing falling into the trap of self-contradiction because of his tendency to be too broad. One is hesitant to be overly critical of Channing for this habit, for he was of ten at his best when making such generalizations. But one can also wish he had been more careful.

Another trait of Channing as a historian, this one deserving of nothing but praise, was his constant warning of students of history to beware the pitfall of projecting one's own standards onto the historical perlod being studied. Examples are numerous, but let this one suffice:

of all the contradictions of history one that impresses the student is the constant and sincere religious fervor of the men with whom he comes into contact whose actions otherwise are often not commendable according to present day rules of conduct. The Span1sh Menendez honestly belleved that when he slaughtered fettered captives it was "for the glory of God." The English Hawkins was equaliy p1ous; on his second slave-trading voyage his flagship was The Jesus. He ordered his crews "to serve dod da1ly" and "to love one another." ...The standards of those days were not the standards of our day, and the standards of three hundred years hence will doubtless be unlike those of our time. 37

Closely related to Channing's debunking Inclinations was his method of convincing the reader of something new and/or controversial without allowing him to get the Impression of argument. An excellent example, appropriately enough, is his

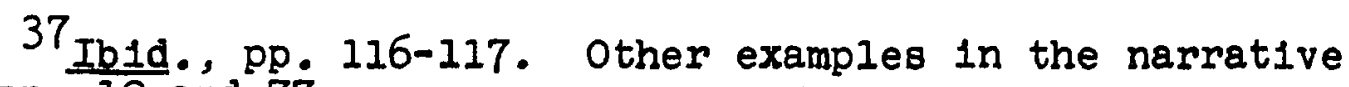
are on pp. 19 and 77 . 
treatment of the Pilgrim landing. "Landing on the shore of what is now Provincetown harbor, the P1lgrims first set foot on American so11, "38 he sald matter-of-factly, and then proceeded with the narration of events. The controversial aspects of the case he relegated to the end-of-chapter bibllographical notes.

There are a few threads of interpretation obvious more or less throughout this first volume of the Great work which should receive mention before a continuation of the chronological coverage. One of these is Channing's treatment of the Indian. He showed great insight in a simple way in some of his comments :

The student of eariy American history can make one generalization with some degree of confidence: so long as the white invaders were fur traders and missionarles, there was peace on the frontier; but when the newcomers were farmers or planters, Indian war broke out before very long. In other words, while their hunting grounds were preserved to the Indlans, they looked upon the whites as the benevolent dispeners of useful utens1ls, pots of iron, articles of personal adornment, fire water, and sometimes firearms; but when the whites began to plow the soll and to build houses, they serlousiy interfered with the Indlans' food supply and with the only article of barter for which the white traders would give the Indian those things which he des1red. 39

But the dominant note in Channing's treatment of white relations with the Indian is one of 1rony. Speaking of Frenoh

$$
\begin{aligned}
& { }^{38} \text { Ib1d., p. } 306 \text {. } \\
& 39 \text { Io1d., p. } 454 .
\end{aligned}
$$


Jesult activities among the Indians of North America, he concluded that "Conversion saved the aboriginal soul in the next world; 1t weakened mind and body in th1s." of Spanish activities on the southeastern coast, he sa1d, "Near at hand was a large river, which the explorers plously named St. John the Baptist, and then set to work capturing Indlans." Channing actually sald more of the later Unlted States attitude toward the Indian than about the Span1sh when he wrote:

The Spanish conquest of America had in 1t certain of the elements of the crusades, the Spanlards sincerely desiring to convert the natives to Christianity. Such of them as became converted were treated with a consideration which was somewhat foreign to the Indian policy of later settlers of the United States. 40

Channing made a distinction, however, between treatment of the Indians by the Spanish and French and their treatment by the Brit1sh, especially in New England. Here, he sald, the colonists tried to deal with the Indians falrly, recognized their clalm to the land, took concern with their education and salvation, etc. 41

Finally, a paradox appears in Channing's attitude toward the Indian. For, after all the apparent concern throughout for the Indian's welfare, he concluded that it was inev1table that Indian contact with the white should prove

40 The three statements are from Ib1d., pp. 108, 61, and 40. Note that Channing, especlally in the second quotation, was not quite so careful as he wished the historical student to be to judge by the standards of the time under consideration. 4I Ib1d., pp. $337-340$. 
disastrous to the Indian, for he was, after all, "the weaker race" : 42

The other two threads of interpretation are religious In nature. One is Channing's att1tude toward religious toleration, or lack thereof; the other is the fact that he sometimes saw God Intervening in the history of man. Channing was careful, as usual, in his remarks on religious toleration, to try to fudge by standards of the day belng considered. "It is well for the student once in a while to look the facts squarely in the face and to remember that while to-day rellglous freedom is a corner stone of American polity, in 1632 uniformity in religion was the keynote of the policy of England," he sald. And in another place, still more forcefully: "It 1 s as reasonable to think of the Union soldier with arms in his hands tolerating an armed Confederate clothed in his garb of grey as 1 is to think of W1lliam Laud tolerating John Winthrop or of John Winthrop tolerating William Laud. In times of stern religlous enthusiasm toleration has no place." But Channing also showed a marked Inclination to be sympathet1c to the victims of religlous Intolerance and to pralse those who supported toleration. Discussing a Roman Catholic priest in England who was scheduled to be executed but whose final fate is unknown, Channing sa1d, "Let us hope that James Interfered in time to save him." And speaking of a proclamation by a group of men

$$
42 \text { Ib 1d., p. } 338 .
$$


of New Netherland supporting religlous toleration even to the extent of tolerating Quakers, he sa1d, "Th1s remarkable remonstrance was signed by th1rty-one men, whose names are worthy of remembrance," and then proceeded to $11 \mathrm{st}$ them. 43

Perhap Channing did not see the hand of God 1ntervening in human events often enough to justify conoldering it a "thread of Interpretat1on." But it seems rather strange that a person as little religlously inolined as he apparently was, and as desirous of considering himself a solentifio historlan, should have relled upon suoh an 1 dea at all. Noting that the French settled in "the cold and barren country of the North" and the Spanish in the subtrop1cal land of Flor1da," he concluded of the vast area in between and of the people who were to occupy 1t:

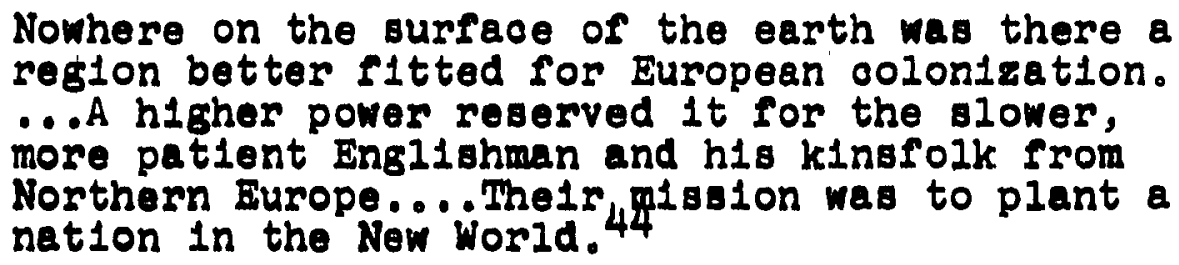
In another place, Channing agreed w1th an earlier writer that "the hand of Qod was heavy" on the Virginia enterprise in 1609-1610.45 Such oomments were also to appear at several points in iater volumes of the History. But the temptation

43 Ip1d., pp. 249-250, 324, 249, and 474 . 44 Ip1d. . pp. 109-110. ${ }^{45}$ Ib1d., p. 180. 
cannot be resisted to state that 1 t seems more l1ke Edward Channing to comment, after noting that Drake and his men had once gotten their ship stuck on a reef and decided to commend their case to the hand of God and had a sermon, that "The shlp thereupon sl1d from her rocky perch, assisted by a sudden change of wind." 46

After carrying the story of Virginia down to about 1641, Channing continued his narrative by devoting a chapter to the founding of Maryland. Both George and Cec1l Calvert came off rather well in this account, the former as "the most respectable and honest of the medlocre statesmen whom James, Charles, and Buckingham gathered about them," and the latter even better as "an astute, capable man," also "tactful and courageously liberal." Channing delineated the reasons for the early lack of prosperlty of the Maryland settlement: toleration of Catholics there tended to make Protestants go elsewhere, the land system was 111 beral compared to other colonies, the proprietor kept a firm grasp on the government, and above all, "the constltutional arrangements of early Maryland were not altogether to the liking of the colonists" because of the "conflicting and amblguous" provisions of the charter. He then concluded by emphasizing that 1t did not compare at all favorably in this perlod with Virginia. 47

$$
\begin{aligned}
& 46 \text { Ib1d., p. 122. } \\
& 47 \text { Ib1d., pp. } 241,250,264-265 \text {, and } 267-268 \text {. }
\end{aligned}
$$


Edward Channing's grandson felt that there were two "highly 1mpressive and fresh interpretations" in this first volume of the H1story. One was his definition of Purltanism; the other, his upgrading of the governors of New Netherland. 48 Channing's definition of Puritanism opened an excellent chapter ent1tled "The Beginnings of New England," In which he traced the English background for "The Coming of the P11grims" and "The Great Migration," the next two chapters. It was a simple but useful defin1tion. "SeventeenthwCentury Puritanism," he sa1d, "was an att1tude of mind rather than a system of theology, --1t was 1deal1sm applied to the solution of contemporary problems." 49 He then elaborated:

In religion it took the form of a demand for preaching ministers and for carrying to its logical ending the reformation in the ecclesiastical fabric which Elizabeth had begun and had stopped halfway. In sosiety It assumed the shape of a desire to elevate private morals, which were shockingly low. In politios 1t stood for a new movement in national life which required the extirpation of the relics of feudalism and the recognition of the people as a power in the State. In short, Purltanlsm marked the beginning of

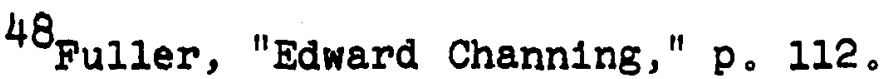

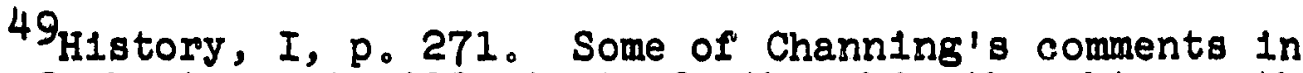
the end-of-chapter note 1liustrate further his thoughts on the subject: "There 1s no good account of the rise of seventeenthcentury Puritanism. The movement was largely soclal in its character; but h1therto all treatment of 1 t has been mainly religious with more or less of politics thrown in. Gardiner's History of England is by long odds the best thing that has yet been done; but he so studiously avo1ds sac1al and economic factors that some of his readers find it difficult to discover why there should have been any Purltan movement at all. The older accounts are almost entirely religious and regard seventeenth-century nonconformity as the child of Elizabethan separation--which is plainly impossible。" (p.292)。 
the rising tide of human asplration for something better than the world had yet known. 50

"If this definition is vague," he concluded, "Puritanism 1tself was vague." 51

Channing's comments on Purltanism compare rather well with those of the great American authority on the subject, Perry Milier. The latter emphasized that Puritanism was more easily described than defined. He described it as "that point of view, that ph1losophy of 11fe, that code of values, which was carried to New England by the first settlers in the early seventeenth century." And M1lier came very close to Channing's definition when he wrote: "Puritanism was not only a religious creed, it was a phllosophy and a metaphys1c; it was an organ1zation of man's whole life..." 52

Noting the rejection by Parliament of a serles of reform proposals drawn up by S1r Edwin Sandys in 1604, Channing concluded that 1 was "not for us to regret the1r action, for their refusal of needed reform led directly to the settlement of New England." The year 1625, which saw the death of James, Channing felt opened "a new page" in English history, for the Commons voted to grant to Charles for only one year the subsldy of tonnage and poundage traditionally granted the monarch for $11 f e$. The Lords voted against th1s, and Charles

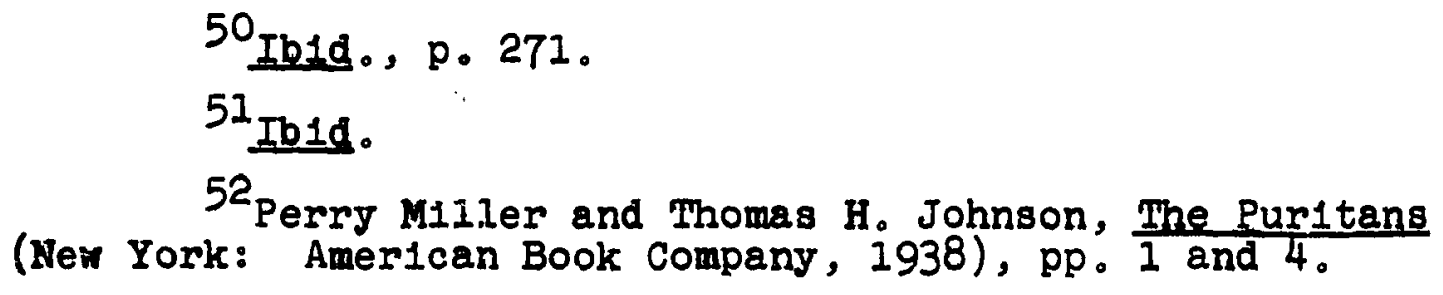


proceeded to collect it anyway, w1thout Parliament's approval, "unt1l the final catastrophe placed the ports of the kingdom and the collection of the customs in the hands of the Long Parliament $[1640-1660] .153$

The Harvard Lampoon doubtless over-emphasized Channing's blas in favor of New England when it described his course in American Colonial History as one "In the history of Massachusetts with. Incldental references to the other colonies." 54 Certainly such a statement would not be accurate as to his apportionment of space in this volume; he was careful to give the middle and southern colonies their due. St111, those who approached it looking for evidence of prejudlce could find some. Channing did, after all, devote an entire chapter to Massachusetts backgrounds, certainly more than he devoted to background for Virginia. He also had some of the strongest pralse he ever had for any Individual for William Bradford: a "most remarkable man," "a scholar," and "a born leader of men,"

he had great common sense and an extraordinary capacity for bringing difficult business trans" actions to prosperous endings. The key to his success lay in the fact that in his own character he realized the sense of his declaration that "ali great undertakings must be both enterprised and overcome by answerable courages." 55

53 Ib1d., pp. 180 and 185-186.

54 Quoted in Glenn Weaver, "Edward Channing: A L1terary Blography, "Soc1al Studles, IIV (March, 1963), p. 88.

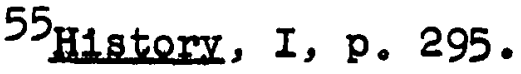


And he spoke fondly of the P1lgrims as a group:

It is the heroism of this pathetic tragedy that gives the Pilgrim story...1ts place in our annals; for, truthfully, it may be sald that the Mayflower brought to American shores that undefinable moral quality which is sometimes called the "New England consclence." 56

In another place, he said, "Probably the world has never seen a more disinterested and law-abiding set of men than those who followed Bradford in the summer of $1621 . " 157$

After noting these statements, however, one should also take notice of what one critic considered Channing's excessive playing down of the Mayflower Compact. 58 Here is what Channing said about the famous document:

The Mayflower Compact...was in the general form of a Separatist church covenant... [It] was not in any way the constitution of an independent state, as has sometimes been said. It was, Indeed, precisely the opposite,--an agreement made by Englishmen who, finding themselves on Engl1sh soll without any specified powers of government, agreed to govern themselves unt1l the king's pleasure should be signified. There was not the slightest thought of independence, and the government thus instituted was legal as between the signers under the Common Law. 59

In the same veln was his already-mentioned treatment of the Pligrim landing at Plymouth Rock. Thls is doubtless

56

Ib1d., p. 308.

57 Ib1d., p. 312.

58 Rev1ew, Robert L1vingston Schuyler, The New York Times, July 15, 1905, p. 464.

59

History, I, pp.308-309。 
the one myth wh1ch Channing went to the greatest length to destroy. It is beautifully satirized in a little poem:

Oh, Channing gets awfully sore, And talks a half-hour or more,

To show that a band of P1igrims can't land, On a rock a half-mile from the shore.60

His comments on the subject in the History were guarded, but st1ll made their point. 61 And his name appeared in print in at least two other places in connection with the landing. 62 And finally, though Channing conceded that "Seldom in history has a more able representative body had so long a

\footnotetext{
${ }^{60}$ Cl1pping in "Qu1nquennial" folder from the Boston Herald, January 8, 1931.

${ }^{61}$ Most of them come in an end-of-chapter note, History, I, pp. 320-321. Here are the significant portions: "It is difficult to treat a subject like this historlcally, because the matter is one of sentiment rather than of fact. We rightly celebrate the coming to America of the 1deals typified in some of the P1lgrims. Harking back to the characterlstics of our. remote ancestors, like them we assoclate events $w 1$ th trees and w1th stones. It is to be hoped that Plymouth Rock may long continue to form the theme of annual after-dinner discourses, and of more formidable set orations. From the historian's workshop, however, the outlook is necessarlly somewhat different. He sees that there never was a "landing" on Plymouth Rock or elsewhere, as described in oration or shown in painting and engraving. P1Igrim foot first pressed the so11 of the New World on the shore of Provincetown harbor..... On the day (December 12-22, 1620) we commemorate as "forefathers' day," we have absolutely no knowledge of the dolngs of the forefathers. The mistake as to date arose in transferring old-style dates to those of modern times and is entirely excusable. The tradition of Plymouth Rook belng used as a landing place goes back to Elder Faunce who, in 1741, at the age of ninety-one, undertook to repeat what he had heard years before from the original settlers."

$62^{\prime \prime} 1$ 1d the Fathers Land on P1ymouth Rock on Forefather's Day?" Magazine of American History, XIII (January, 1885), p. 103; and "Remarks on the course and landing of the P1Igrims at Plymouth," Proceedings of the Massachusetts Historical Soclety, XVII $(1903)$, pp. 381-382.
} 
measure of Iffe as the Massachusetts General Court," he emphaslzed that "John Winthrop was in no sense a popular man or one who had any confidence in what would nowadays be regarded as liberal government" and that "the government of the Bay Colony was...an aristocratic republic, that is to say a republic in which the franchlse was strictly limited to the upper classes."63 In other words, the government of colonial Massachusetts was not a democracy. 64

Other highlights in Channing's coverage of the history of New England in this perlod are his comments on the Great Migration, Rhode Island, Connecticut, and the New England Confederation. Here is his summary paragraph on the Great Migration and its signiflcance:

The Great Emigration was in many respects singularly like that earlier fleeing of the Israelites into the w1lderness. In both cases the relig1ous motive was at the bottom, and the exiles forsook the fleshpots of their earlier home, which was, to use Winthrop's words, "some pinch to them at first." As the Israelites clave to their God and to the religion which he gave to them, so the Massachusetts leaders left the land of their birth to establish a "particular church" in the Amerlcan wliderness and to nourlsh and watch over it in 1 ts infancy. They had not the remotest thought of founding in New England an asylum for the religiously persecuted of the earth. What they came here to do was to secure the freedom of their own consclences. They departed from thelr

\section{$63_{\text {H1story, }} I, p .348$ 。}

${ }^{64}$ It is interesting, in view of this, that Channing once wrote to Charles Franc1s Adams, Jr., that he belleved $1 t$ was to the Puritans of New England "that the foundation of legal and political equality is due." (January 30, 1892 , Adams Family Papers, Massachusetts Historical Soclety, Boston.) 
country, kindred, and fathers' houses that they might enjoy divine worship without offense either to God, man, or their own consciences; or, as Winthrop expressed 1t, "to I1ve under a due form of government, both c1vil and ecclesiastlcal." They came to establish a Bible commonwealth in which they should play the principal parts and bend others to their w111.65

Channing gave Rhode Island's founder, Roger W11liams, favorable treatment, 66 and had nothing but pra1se for Rhode Island 1tself:

In thode Island, Ind1v1dualism has always had 1ts highest development; in colonial days there was no capital in which the people of all the settlements were on a footing of equality. The General Assembly had no flxed place of meeting, but convened succesively in different parts of the colony. There vere no rules in Rhode Island by which affairs should be carried on; what one found on the 1sland of Aquidneok he might be reasonably certain he would not find in Provincetown or in Warwick. There was one great exception to this general statement: everywhere in the colony men held strong opinions, and everywhere there was extreme toleration for the 1deas of others. In such a community, men of power and Independenoe were $11 k e l y$ to ar1se who would profoundiy 1nfluence the thoughts, I1ves, souls, and dolngs of others; and such men have been Rhode
Island's chiefest contribution to American nationality. 67

Two things especially strike the reader in Channing's account of the early years of Connectlout's history. One is his emphasis on the fact the dominant motivation in its settlement was "that incessant search for cheaply acquired fertile lands which has been one of the mainsprings of the growth of

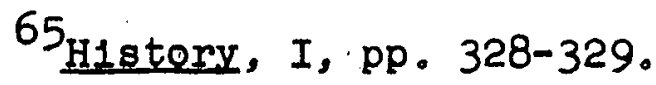

${ }^{66}$ Ib1d., pp. $362-368$.

67 Ib1d., p. 398. 
the United States." The other is his evaluation of the famous constitution known as the Fundamental Orders of Connect1cut of 1639. He did grant 1t "the distinction of being the first written political consitution in which the functions of government are formulated in deta11," but he also pointed out that 1t "did little more than to formulate on paper the existing government of Massachusetts Bay." 68

Channing consldered the New England Confederation of great significance:

Conslderlng the lack of experlence whlch the framers of this federal pact necessarliy had in the drawing up of a constitution, this document is a remarkable production. It did not put a final ending to disputes between the four colonies, and it sometimes proved to be unsulted to the exigencies of the time. Nevertheless, the articles continued without amendment for forty years; they carried New England successfully through the fiercest Indian war of the seventeenth century. Had the confederation been in existence in the next century, it is very possible that the northern colonies might have been saved much of the misery of the French and Indian Wars. 69

Channing's upgrading of the governors of New Netherland, which his grandson considered an important interpretation in this volume, obviously did not include the best known of those governors, Peter Stuyvestant, for the chapter which dealt with him was called "The Misrule of Peter Stuyvestant," and characterized him as a "crusty, hot-tempered offlc1al"

68

Ib1d., pp. 399, 404-407.

69

Ib1d. . p. 419. 
and a "despot."70 Channing did attempt to alter favorably the reputations of Wouter Van Twiller and William Kleft.71

"The early Stuarts and the Puritan rulers of England were so fully occupled with English politics that they had no t1me to interfere" with the development of the colonies along Ines "radically unlike those which prevalled in England," noted Channing as he neared the end of the flrst volume of his magnum opus. "From the beginning the English colonies in America had enfoyed a large measure of freedom from the control of the mother country; since the accession of Charles I they had exercised practical self-government." Channing made it clear that this helped explain colonial opposition to later British measures, specifically the Navigation Act of 1651. He explained this latter measure, incldentally, as primarily "one step in a serles of acts all having for their alm the restrictIng of English and colonial trade to English and colonial vessels" going all the way back to the time of Rlchard II and not as a result of the commercial rivalry with the Dutch as many others had done. ${ }^{72}$

It was only in the closing pages that Channing saw f1t to return to what he saw, according to his preface, as "the most important single fact in our development:"

$$
\begin{aligned}
& 7^{70_{\text {Ib1d. }},} \text { pp. } 461-462 . \\
& 7^{71_{\text {Ib1d. }},} \text { pp. } 450-459 . \\
& 7^{72_{\text {Ib1d., }}} \text { pp. } 421,485,490-491 .
\end{aligned}
$$


In studying institutional topics, it is necessary to note both similarities and dissimilarities. This is especially true when investigating the history of the communities which later developed into the United States. The greatest fact of American history has been the union in one federal state of peoples living in widely separated reglons under very different conditions of soclety and industry. Th1s union was made possible by the fact that the institutions and the political 1deals of these communities had in them so much that was akin. Institutional and social peculiarities strike the student's attention with much greater force than do those things which are common to all; it is therefore necessary to be especially careful not to be unduly affected by that which is quaint or abnormal. The most marked political characterlstic of the English race has always been its conservatism in adhering to that which is old for no other reason than because it $1 \mathrm{~s}$ that which exists. It was this quality that made republican and democratic institutions possible in English communities. It was this spirit of conservatism that preserved in the English colonies the political and constitutlonal 1deas which made the forces of union always more powerful than those that operated toward particularism. 73

Finaliy, though he did not polnt out that the colonies were essentially left alone and allowed to develop along their own IInes in the period from 1607 to 1660 , Channing concluded by emphasizing that the colonists at the end of that period were st111 Engl1shmen:

Human nature, in short, was much the same in Virginia and Massachusetts, in Maryland and Rhode Island, that it was in contemporary England... The colonists were st1ll Englishmen in the1r feelings and prejudices, in the ir virtues and in their vices. Contact with the wilderness and freedom from the constitutional restraints which held down Englishmen in England had not yet brought to the surface the latent elast1c1ty of the Germanic race, had not yet resulted in making the colonists

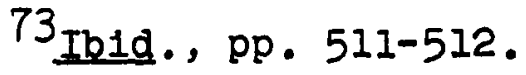


Americans. A century of exposure to colonial conditions was required to force the English in America away from the traditions and 1deals of those who continued to Ilve in the old land. The year 1660 marks an epoch in the history of the English race because the Restoration denoted the breaking down of the desire for reform in England and the intensifying of those forces which the Puritans had striven to overthrow. In colonial history it ended the first period in our annals. It sow a nation definitely planted in the New World. 74

That this first volume of the Great Work did not receive one generally critical review has already been noted; so have two of the minor criticisms which were made--Channing's treatment of Spanish exploration and his excessive playing down of the Mayflower Compact. Channing's grandson probably summarized the reviews as well as possible when he sald, "The reviewers of this first volume recelved it with moderate praise."75

Channing responded perceptively to the reviews of volume I, and book reviews in general, in a letter to Brett dated September 2, 1905:

The notices of vol. I have been generally favorable but Amerlcan book reviews are poor things. When I was young and had not got my footing in Harvard University I used to write book notices + know just how It 18 done. I gave them a nice preface to my vol. 1 + they have made full use of 1t. I presume that book notices pay the publishers or review coples would not be sent. $76^{\circ}$

Channing did not regard too highly the review in the Nat10n. "I thought that the 'Nat1on' notice meant well," he

74 Ib1d. , pp. 536-537.

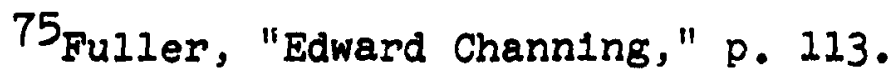

${ }^{76}$ Channing to Brett, September 2, 1905, Macmilian Collection. 
wrote to Brett, "but that the writer was incompetent and had not read much of the book."77 And he was right. The anonymous reviewer could find virtually nothing to criticize about the volume, but his comments were at times simply unfathomable--as, for example, when he stated that "the political institutions of the colonies are dismissed with a brief, though often a discriminating, treatment," then went on to justify the brevity of treatment by concluding that 1 t was "unhistorical to ascribe to them [the colonies] a political quality which was apparent only after the event." Some have sald of Channing's History that it was entirely too political; and, as for the last statement, what does 1t mean? The revlewer had praise for Channing's style, considered his realization of his dual goal of seeing the colonies as a part of the English Empire and of viewing the subject as the record of an evolution as "the distinguishing characteristic" of the volume, and conoluded that "to do just1oe to the book it is necessary to read 1t, and that 18 undoubtedly what all students of Amerioan history w11l do wh1le awa1ting the subsequent volumes." 78

The comments of w1111am Roscoe Thayer in a review artiole in the Atlantie Monthly Channing considered "rlatter1ng." Thayer made some val1d polnts, but he did wax rather eloquent when he said that, from Channing's beginning, "1t is

77 Channing to Brett; undated but apparently written in July, 1905, Macmilian Collection.

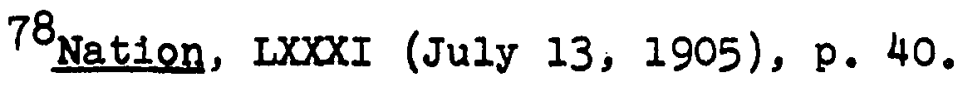


evident that this w111 be a standard history":

He writes with perfect independence, after weighing all the testimony. He is very sober-minded, with a preference for moderate statement, and for reducing legends to their lowest terms....As there is in Amerlca no historian more careful and thorough than he, and none more loyal to the sclentific method, so it is noteworthy that he has given great attention to the literary form of his history. From the promise of his first volume one may predict that he w1ll hold for years to come a position similar 58
that held by Bancroft in an earlier generation. 79

C. H. Van Tyne, of the UnIversity of Michigan, praised Channing's work highly in a review in the Annals of the American Academy of Political and Soc1al Sclence. He felt that "In scholarship the work eas1ly leads any other attempt of the kind," and considered the style "clear, pleasing, and admirably simple." Other than the already-mentioned unsympathet1c treatment of the Spanish explorers, the only criticlsm Van Tyne could come up with was that there could have been more European background placed before exploration and discovery in the narrative, and this he did not consider particularly important. He praised the bibllography ("Nothing more valuable exists for the use of the advanced student of American h1story"), noted Channing's ablilty to differ with tradition w1 thout leading the reader to question him, and conc luded that the volume stood "In the forerront of scholarly efforts to tell the h1story of this country." 80

${ }^{79}$ Channing to Brett, undated but apparently written in July, 1905, Macmilian Collection; W1lilam Roscoe Thayer, "The Outlook in H1story," Atlant1c Monthiy, XCVI (July, 1905), p. 77.

${ }^{80}$ Annals of the American Academy of Pol1tical and Soc1al Selence, XXVI (September, 1905), pp. $422-423$. 
Interestingly, The Planting of a Nation in the New World was well-recelved by the reviewer for the English H1s= torlcal Rev1ew. He emphas1zed Chann1ng's moderation, especlally in dealing with the relations of the colonies to the mother country:

Between the mother country and the colonies he holds the scales falr, doing justice to Great Britain without falling into the exaggerated Imperialism of some recent American authors. Though his heart is with the colonists he does not fall to point out their weaknesses, and though tracing in deta1l the record of English mlsmanagement he rarely exaggerates. 81

Edward Gaylord Bourne made it clear in the American Historical Review that his only criticisms of the volume dealt w1th "smaller details connected with the perlod of discoveries." His over-all evaluation was fllled with praise. 82 So were those in Dial and Public Oplnion. 83 The comments of Theodore C. Sm1th, a former Channing student, in the Atlant1c Monthly, are typical of the "moderate praise" th1s inftial Installment of the Great Work recelved, and serve as a fltting conclusion here. After noting that the quality wh1ch made the book "stimulating" and "noteworthy" was "the impression of

81W1111am L. Grant, Engi1igh B1storicar Rev1ew, XXIV (January, 1909), pp. 145-146. Th1s Was aotualiy a roview of both volumes I and II; there was not really much on relatione botween mother oountry and oolonies in volume $I$, but the good reoeption of the work seoms signifloant at this otage.

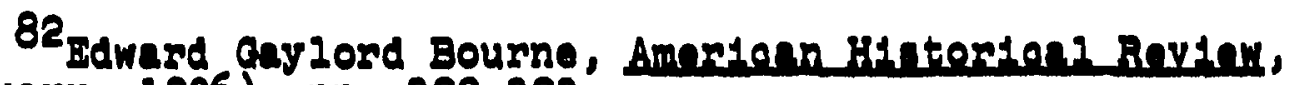
XI (January, 1906), Pp. 390-393.

83st, goorge I. S10ungat, D1n, XXXIX (Augunt 16, 1905) Pp. 83-84; and Eub1to Opinton, XXXIX (Augunt 5, 1905),
p. 188. 
personality and individual authority," he concluded:

Beginning without introduction or flourish, the author narrates the course of events, emphasizing important points, calmly lgnoring minor ones, never theorizing, never arguing, but evincing a steady clearness of judgment which appeals to the reader with growing power. The sense of balanced judgment is reinforced by the shrewd, occasionally ironlcal or humorous style which reflects the personal1ty of the author. The book is not universal, it is not even broad; it is just the utterance of the personal opinions of Edward Channing, who has devoted his life to ${ }_{8}$ this particular field. It is alive a.1 through. 84

\footnotetext{
84 Theodore Clarke Smith, Atlant1c Month1y, XCVIII (November, 1906), pp. 702-711.

The comments of two reviews are relegated to footnote status because of their inaccurate, though interesting, comments. Robert LIvingston Schuyler, in the New York Times, July 15, 1905, noted wrongly that Channing steered clear of the numerous controversies centering around Columbus, then went on to the shockingly false conclusion that "Channing follows the safe plan of always agreeing with the majority and is wise in doing so, for he has none of that special ability, of making the worse appear the better cause, which charms while it warns us to caution, in such a writer as John Fiske." (p. 474) Henry Russell Spencer missed the point just as badly, and in perhaps an even more important way, when he decided that Channing's work was "evidently designed and probably destined" to be a popular work for reading by the layman! He apparently came to this conolusion because he could not find any "distinctive unifying principle" to justify re-telling the story to scholars--one cannot help but wonder if he read the preface and final chapter--and because he considered Channing's use of the sources "to have been such as would be dictated by his writing to the general reader." This last 1dea the reviewer could not even reconclie with his own oritic18m of Channing for taking up too much space by quoting from the sources, much less with the justiflable praise accorded Channing by Morison and others for h1s w1de searoh of the souroes.--Polit108.1 Solence Quanteriy, XXI (June, I906), pp. 346-348.
} 


\section{A CENTURY OF COLONIAL HISTORY}

The volume w111 not be readable except in spots; but it will please the profession and will give the set a good position. 1

One Saturday mornlng Edward Channing was seen in the Harvard Library by an acquaintance who asked him if he were going to the football game that afternoon. "No!" Channing replied, almost Indignantly, and continued, "Do you know what I am going to do this afternoon? I shall work in the 11brary unt1l it closes, then I shall go home and work."2 This became more and more typlcal of his hablts as the Great Work proceeded.

Channing was at work on volume II while volume I was. still in progress, for he wrote to Brett in September, 1904, that the first was almost ready and the second about half done. He first ventured an estimete as to when he could have volume II completed in June, 1906--he thought he could make it by March of the following year. But he was over-optimist10, for about a month after that proposed deadilne he was assuring Brett that dropping the Radoliffe portion of his teaching "means extra speed on Vol. II." In August, 1907, he thought

\footnotetext{
${ }^{1}$ Edward Channing to George P. Brett, [President, Macmilian Company], Apri1 26, 1908, Edward Channing F1le, Macmillan Authors Collection, Manuscript D1v1810n, New York Public Ilbrary.

${ }^{2}$ Interview with Robert H. Haynes, August 24, 1966 , Cambridge, Massachusetts.
} 
it was about ready. ${ }^{3}$ A Century of Colonial History was finally published in August of 1908.

Perhaps part of the reason Channing could not meet his time-table lay in the peculiar difficulties with which this volume presented h1m. "There is no good secondary work on the period between 1660 and 1760 ," he lamented in his bibllographical comments at the end of the first chapter. ${ }^{4}$ At the time he was writing, it was certainly true that this was a generally neglected period; that it was true showed in Channing's work. For, though 1 it is an exaggeration to say, as some have, that Channing simply strung together a bunch of monographs, it is true that when he did not have the works of others to rely upon, the quality of his own work suffered somewhat. He seems to have realized this himself, if we can accept the letter quoted at the head of this chapter as any indication. Paul H. Buck considered volume II the weakest of the $81 x .^{5}$ Reviewers were kind, but they too noted the problem. The Dial felt that, "If any unfavorable oriticlom be deserved," 1t was that the ooverage was better to 1688 than after; the explanation for this was that Channing had rloher monograph10

3 Channing to Brett, Soptember 16, 1904, June 11, 1906, undated but apparentiy written in Apr11 of 1907, and Auguat 7,1907 , Maomilian Colleotion.

4 Edward Channing, A History of the Unjted States. Volume II: A Century of Colonial H1story 1660-1761 (New York: The Macmilian Company, 1908), p. 26. Massechusetts.

Interview with Paul H. Buok, June 9, 1967, Cambridge, 
11terature to rely on for the earlier period, whereas the later years had been largely neglected ${ }^{6}$ The more able review in the American Historical Review clarified the situation further, and drew some interesting conclusions. Noting that the years 1689 to 1750 had been the most neglected of this generally unworked period, and that scholars had thus awaited with particular expectancy Channing's account of those years, he went on:

If, after a perusal of the volume, we find it measuro Ing up to a higher standard than that attalned by 1ts predecessors, we may deem the praise well earned; if, on the other hand, we find it falling short of the 1deal, we may discount our criticism by noting that the day has not come when the history of this troublesome elghteenth century can be written ade quately.... That Professor Channing should have

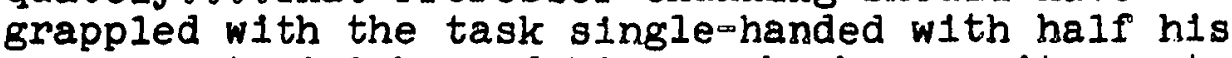
source materlal beyond his reach, bears witness to h1s courage; that he should have produced a book destined for some years to stand alone as the only competent history of the period is a certalin proof of his ability and understanding.

After delineating what he considered to be some of the major spec1f1c weaknesses and strengths of the book, the reviewer concluded:

We may not agree with all that Professor Channing has sald or be entirely satisfied with his way of treating the history of this period, but we do acknowledge that he has produced a book of first importance for the study of the neglected period and in so doing has removed a reproach bitherto cast upon historical scholarship in America.8

${ }^{6}$ St. George Leak1n Sloussat, D1al, XLVI (May 16, 1909), p. 328 .

${ }^{7}$ American Historical Review, XIV (January, 1909), p。 364. This review was unsigned, but J. Frankin Jameson, who was the editor at the time, apparentiy wrote it himself。

8 Ib1d.p. 366 . 
In general terms, volume II covered four maln subjects, One of these was certain aspects of the social and cultural history of the period, such as labor, immigration, religion, and education. Second was the history of individual colonies. The Anglo-French struggle for control of North America, culminating in the French and Indian War, constituted a third distinct topic. And finaliy there was the all-important theme of relations between the mother country and the colonies, with particular attention, of course, to such commercial aspects of colonial pollcy as the Navigation Acts.

Reviewers differed widely in their evaluation of Channing's treatment of the first of these subjects, 1,e. the soclal and cultural material. One felt the most obvious shortcoming of the book was the inadequate attention given to these topics, and that only religion received adequate attention. Another, however, referred to these chapters on labor, education, Industry, and the like, as "brilliant little essays." And st1ll another thought they were "excellent." 9 Probably the most important thing to note 18 that Channing was departIng somewhat from tradition even in giving such materlal the coverage he d1d. It is true, however, that the flve chapters near the end of the volume which were devoted to this type of subject matter left something to be desired.

9 Emory R. Johnson, Annals of the American Academy of Pol1t1cal and Social Sclence, XXXIII (March, 1909), 0. 245; St. George Leakin S1oussat, D18, XLVI (May 16, 1909), p. 328; Nation, IXXXVII (November 5, 1908), p. 440. 
The chapter ent1tled "Systems of Labor" 1 s extremely interesting reading, but it actualiy deals only with indentured servitude (brlefly) and slavery (extensively); there 1s nothing on free labor in the colonies. Perhaps the dominant impression In the reader's mind upon completion of this chapter is the problem which Channing seems to have had in remaining objective when dealing w1th slavery. He suppressed extreme statements, but his feelings came through. He halled as "Some of the more farsighted" those V1rginia planters who lamented the increase of slavery; he treated favorably the earliest Amerlcan protesters agalnst human slavery; and he concluded the chapter thus:

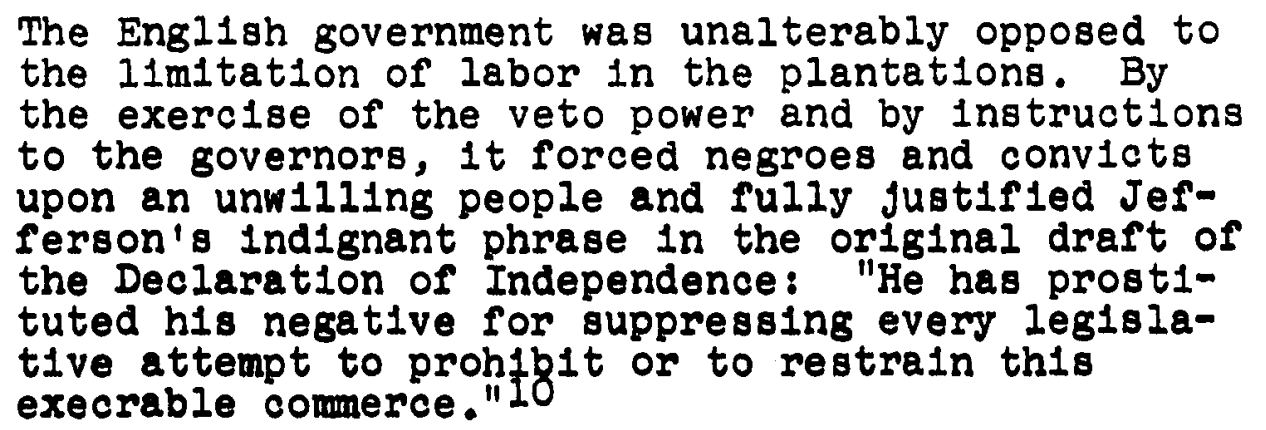
A hint of prejudice showed in another way when Channing emphasized certain (admittediy true) statements about how different slavery was in Massachusetts, particularly the smaliness of number and the generosity of treatment. ${ }^{11}$ st11l, in all falrness, Channing's constant attempt to avo1d superimposing his

\footnotetext{
10 H1story, II, pp. $377,395-398,398$.

${ }^{11}$ Ibid., pp. 383-385.
} 
own day's set of values upon the period being considered should be noted. After discussing at some length the modes of punishment of slaves, he emphasized that these "were rather a mark of the time than the infliction of cruel and unusual punishments on any one particular portion of the community, "and concluded:

These punishments appear ferocious to the modern reader. It may well be asked, however, whether in the less nervous condition of human beings in those days and the different standards of shame which prevalled they were not actually much less severe than they would be at the present time, when the human body and mind are more highly strung? 12

"The Coming of the Forelgnerg" dealt primar1ly, of course, w1th non-English 1mmigrants to the colonies, the French Huguenots and the Germans recelving special attention. The former Channing praised as an "Industrious, inteli1gent, and upright race." The latter he credited with being "a mart1al race" which had always given 1ts service "In defense of freedom and of right" whenever required. 13 some brief coverage of such reforms as poor laws, hospltals, and prisons also made 1ts way Into this chapter. Here Channing halled Pennsylvania for 1ts reform leadership, and concluded that the colonies had advanced beyond Europe in these areas by 1760.14

12 Ib1d., pp. 392-394. Even th1s pitfall Channing d1d not completely avoid in this chapter, for, after noting the minimal fines assessed on a man and a woman for kidnapping a young girl in. London and sending her into servitude in the colonies, he stated that, "had they stolen goods to the value of a few shillings, they would have been sentenced to death as felons, and then berated the judges for the 1r "callousness to humán suffering." (p. 369)

13 Ip1d., pp. 403, 411.

14 Ib1d., pp. 416-420. 
Channing's sympathetic attitude toward victims of religious intolerance, which became evident in his first volo ume, continues in the chapter entitled "Religion and Tolerat1on, 1689-1760." More 1mportant, however, are his accounts of the conflict over the appointment of a separate Anglican bishop for the colonies and of the Great Awakening. The former can be dismissed briefly, for the interesting thing is the rather strange conclusion whlch Channing drew after briefly tracing the conflict: "The eplsode 1s important, not only In 1tself, but as showing how careful the English government was of the feelings and desires of the colonists."15 He certainly did not feel that the English government was careful of the feelings and desires of the colonists in other areas!

The great religlous revival of the elghteenth century known as the Great Awakening in the American colonles recolved rather extensive coverage from the pen of Channing. "Earthquake and pestllence had something to do with preparing the minds of the people for emotional exc1tation," he noted, "but that it came when 1t did was due to the presence and exhortations of two remarkable men, Jonathan Edwards and George Wh1tefleld." Edwards, Channing considered "a mental prodigy," w1th "wonderful sk1II in the use of language and remarkable power of expression." Whitefield was a person whose "remarkable power of stirring human souls" was eloquently testifled to by the fact that Benjamin Franklin once began 11 stening to

$$
{ }^{15} \text { Ib1d., p. } 434 \text {. }
$$


one of his sermons determined not to give a penny when the collection was taken and ended by giving all the money he had in his pockets. Channing refused to cast any doubt on the sincerity of Edwards, Whitefleld, and other Great Awakening preachers, but he was perfectly wliling to emphasize the detrt mental effects of their work. The "manifestations" or "bodily effects" which the sermons frequently produced on their hearers "were the least ev1l part of the results which accompanled the revivals," he noted, and went on:

Many strongly religlous men in New England and elsewhere doubted the goodness of the work which the revivalists were dolng. Later Edwards himself seems to have come to a realizing sense of the ingufficlency of the work and to have admitted that bod1ly pain and excitation were not true religion. In polnt of fact, the Great Awakening resulted in the formation of two groups of Congregationalists in Connecticut and in the lessenIng of the hold which religion had on the people throughout the colonies. So far as the breaking down of the barriers between denominations denoted a diminution of the influence of religion, these results are to be deplored; for 1t must be remembered that religlous liberalism has ever gone hand In hand with religlous indifference; the religious enthusiast is always intolerent. 16

At the end of each of the serles of chapters under consideration, Channing made an attempt to relate his toplc for the chapter to the general colonial situation in 1760 . The attempt as regarding religion is quite thought-provoking:

The sternness of religlous belief, which had strongly marked the perlod of early colonization, in 1760 had given way to mental exc1tation over

$$
{ }^{16} \text { Ib1d., p. } 443 .
$$


questions of the political rights of the colonists and of the connection between those rights and constitutional limitations. It is not until the time of the Stamp Act that these considerations come out prominently; but the breaking down of religious bellefs, or the lack of 1nterest in religion, which plainly appears in the reaction from strictness in religlous observances, may be regarded as leaving the colonial mind open to new Impressions, to that new train of thought which was so sedulously cult1vated by the political writers of the ten years before 1775 . It is for this reason that the religlous condition of the colonies in 1760 has been so fully treated at this place. Philosophy, which up to the middle of the century had concerned itself mainly with religion, from this time has to do chiefly with politics. To this the ever widening opportunities of inteliectual improvement powerfully contributed. 17

The first thing to note about "The March of Education, 1690-1760," though by no means the most Important, is its diversity. Education 1s covered, true enough, but so are witchcraft, Inter-colonial communication, the postal service, and, finally, printing, with particular emphasis on newspapers and freedom of the press. Channing must have felt, quite simply, that he did not have enough material on these other subjects to just1fy an entire chapter.

It must be admitted, however, that Channing made a rather good case for connecting witchcraft with education. "The second half of the seventeenth century w1tnessed the lowest stage of colonial culture," he said. "The witchoraft persecutions of 1ts last decade closed th1s epoch of progress downward." He made a major point out of maintaining proper

\section{${ }^{17}$ Ib1d., p. 454 .}


perspect1ve, as usual, making an off-the-cuff reference to an averred witchcraft ep1sode in 1901. St111, h1s comments, especially on the 1692 Salem eplsode, were hlghly critical. Cotton Mather was said to have "had great influence in preparIng the minds of the people of New England for the appearance of witches in their midst" by his writings on that subject. Governor Sir W1Il1am Ph1ps was "an 1gnorant, superstitious, well-meaning person, who was extremely 111 fitted to cope with such a crisis." And of the episode as a whole he concluded: "There can be little doubt that in the course of these persecutions the charge of witcheraft was used for purposes of private revenge and also to get rid of unpopular persons."18 In the really quite brief comments on education, New England in general and Harvard in particular came off very

18 Ibld., pp. 456-462. Channing elaborated as follows on the causes of the Salem delusion: "W1th the knowledge that is at present avallable as to the structure and working of the human brain, it is not difficult to account for episodes like the witchcraft delusion in Massachusetts and the rel1g1ous revival of fifty years later throughout the colonies. H1story $1 \mathrm{~s}$ ich in reproductions of the characteristics of remote progenitors; thus, after the manner of the ancient Drulds, men and women, even at the present time, delight to venerate trees and stones, and occasionally to return to the thoughts of those early peoples who belleved in the reality of ghostilke appar1tlons that nowadays are regarded as chlld1sh. By long dwelling on things super-natural, the mind compels 1tself to belleve in them, and one human brain by concentration affects another without the medium of ordinary physical action. When the results are beneflclent or are not harmful, they are denominated spir1tual1sm, hypnot1sm, telepathy, mental suggestion; when, in times past, they were malevolent, manifestations of unknown forces were termed witchcraft." (p. 456) 
we11. Channing set the scene in a general way for his educational comments in this fashion:

With the opening of the eighteenth century new forces came into play, not only to enlarge the settler's materlal outlook, but to liberalize his mind. Among these were the constant.discussion in political gatherings, the establishment and spread of newspapers and magazines, and the great enlargement of the means for literary and sclentific education. Schools and colleges were everywhere founded and Improved, but perhaps the most potent influences were the assemblings of professional men, merchants, and agriculturists in the colonial legislative bodies, the town meetings, and the open elections which were the rule in the colonies to the south of the Hudson. 19

His mention of newspapers here helped $\mathrm{h} 1 \mathrm{~m}$ make the transition to his coverage of the John Peter Zenger libel trial.

Channing emphat1cally stated that "the outcome of the Zenger case was of the utmost signiflcance" for America. In his concluding remarks, he made it eminently clear why this was true:

After 1735 there were unjust l1bel su1ts, and the example of the Jury in the Zenger case was not always followed; but Gouverneur Morris was nevertheless correct when he sald that the trial of Zenger was "the morning star of that liberty which subsequently revolutionized America." The importance of this decision lay in the fact that the newspapers which were printed in the colonies after that time came to be the vehicle of Instruction on the constitutional status of the American colonists and on the rights of the Americans as men in the light of the law of nature and of theory. These articles were written by the ablest politicians and literary men of the day in America. The discussions which constantly took place in assemblies, town meetings, and commlttees were also published in the newspapers. They kept alive and directed the forces of liberty and finally brought

19Ibid., p. 462 . 
about the inevitable separation from the mother country sooner than 1t would otherw1se have occurred. Had the newspaper press been muzzled, it is possible that the Declaration of Independence might have been written, but 1t certainly would not have been adopted by a Continental Congress in the year $1776,28^{r}$, in all probab111ty, for many years thereafter. $28^{\prime}$

The last of the five non-political chapters, "Colonial Industry and Commerce," Included good brief discussions of agriculture, industry, commerce, and the currency problem. Most of the material therein relates better, however, to the toplc of relations between England and her colonies.

Doubtless the least satisfactory part of this weakest volume of the Great Work was Channing's account of the history of Individual colonies during the years 1660 to 1760 . This must have been the material uppermost in his own mind when he expressed concern about the readabllity of the work. Though he tried hard, the five chapters which loglcally fall into such a categorization make for pretty drab reading. He waxed eloquent now and then, as when he referred to Dyer's Rebeli1on in New York in 1680 as "the first colonlal rebellion against taxation from England," then went on to say that 1 t carried one "backward to the times of the Puritan Rebelilon in England and forward to the days of Otis, Henry, and Dickinson in Amer1ca." But one wonders here whether he really meant 1t, or was simply trying to make something sound dramat10. 21

$$
\begin{aligned}
& 20_{I b 1 d}, p p .488-489 . \\
& 2 I_{\text {IbId., }} .60 \text {. The fIve chapters referred to are } \\
& \text { numbers II, III, IV, XI, and XII, entitled respectiveIy "New }
\end{aligned}
$$


There are some highlights in these chapters. One is Channing's brief account of King Ph1l1p's War, 1675-1676. Though he repeated here his bellef that "The pollcy of the New England colonists toward the aboriginal 1nhabitants of that region had been enlightened and humane from the beginning," Channing did recognize the problem of the Indians being pushed off their lands. Thus he saw the conflict as "one desperate attempt to regain their lost hunting grounds." The effort falled, of course, but the major significance to him was the extent to whlch 1 t weakened New England militarily, financlally, etc. 22

Channing's account of Bacon's Rebellion is relatively dispasslonate, though he did feel that "Bacon and those who abetted him represented the democratic elements in Virginia soclety as opposed to the aristocratic desires of Berkeley and h1s followers," and concluded the chapter w1th a sentence wh1ch seems to 1mply more than 1t really says: "From this plcture of royal oppression it is pleasant to turn to the attempts of humbler men to right the $111 \mathrm{~s}$ of humanity by governing through love instead of through fear." 23 .

York and New Jersey, 1664-1680," "Virginia and New England, 1660-1680," "The Founding of Pennsy Ivania, 1681-1690, "Seventy Years of Pennsylvania Politics, 1690-1760," and "Carolina in Commotion, 1689-1750."

$$
\begin{aligned}
& 22 \text { Ib1d., pp. 76-79. } \\
& 23 \text { Ib1d., pp. } 88,91 .
\end{aligned}
$$


The group which Channing credited with attempting to govern through love was the Quakers. He pralsed them in other ways, too:

$$
\begin{aligned}
& \text { The Quakers were "a peculiar people," so far as } \\
& \text { religion and soclal institutions were concerned; } \\
& \text { but as to politics, they were ordinary, everyday } \\
& \text { Englishmen. They had that distrust of parental } \\
& \text { and theoretical government which has ever been } \\
& \text { the mainstay of the Anglo-Saxon race... } 24
\end{aligned}
$$

The Pennsylvania Charter of Privileges of 1701 Channing also regarded very highly. "It 1 s the most famous of all colonial constitutions," he sa1d, "because 1t contained in 1ts provisions many of the most important features of all workable written constitutions."25 And finally he lauded the pacifistic Quaker legislators who voluntarily resigned in the French and Indian War crisis of 1755: "Retirement from public life under such circumstances and for such reasons is an act of public spirit and political disinterestedness that seldom has been paralleled in the history of legislative bodies."26 But Channing could not brook what he considered the "Interferences w1th personal freedom" in connection with the disclpline enforced on members of the Society of Friends. 27 And he had only moderate praise for the founder of Pennsylvania, William Penn. He seemed to regret that Penn had been so "flercely assalled" by American

$$
\begin{aligned}
& 24 \text { Ib1d., p. } 122 . \\
& 25 \text { Ib1d., p. } 322 \text {. } \\
& 26 \text { Ib1d., p. } 339 . \\
& 27 \text { Ib1d., pp. 101-102. }
\end{aligned}
$$


colonial historlans, but he agreed that there was much in Penn's career which was "hard to reconclle with the uprightness of character and scrupulousness of dealing which one has a right to expect in a leader of a religous sect." "In point of fact," however, he concluded, "Penn should not be judged as a man of affairs. He was an 1dealist whom chance placed at the head of a great business enterprise, and he experienced the fate that befalls the dreamer when he has to do with actualities." 28

Most would agree that Benjamin Franklin was Pennsylvania's greatest product of the colonial period. Channing once spoke rather critically of him in a personal letter:

He certainly was a man of many sides, some of them not so creditable as one could w1sh. I suppose we must always regard $\mathrm{hlm}$ as one of the three greatest scientists America has given to the world. And yet I am always disappointed in the somewhat sordid turn which Frankiln always gave to h1s observations.29

Th1s letter was written in 1894. Channing must have changed h1s mind by 1908 for here he referred to Franklin as "the greatest mental prodigy ever produced in Amer1ca." Here are Important excerpts from his more extensive comments:

28 Ib1d., pp. 102-103. Channing could not res1st a b1t of humor in his evaluation of one of Penn's religlous pamphlets: "Possibly Penn had no distinot 1dea as to what he meant to convey in the theses which made up his pamphlet; certainiy one modern reader has not acquired definiteness of Impression from 1 ts perusal." (p. 104)

${ }^{29}$ Channing to Samuel A. Green, January 3, 1894 , Samuel A. Green Papers, Massachusetts H1storical Soclety, Boston. 
Foremost of the leaders in Pennsylvania politics was Benjamin Franklin, the first great Americas。o.He was always a leader, whether as a journeyman in a printing office, member of a literary club, or of an assembly; always, unt1l age lessened his vigor, wherever he might be, he was the first among equals. Facility in the use of his fingers was joined with an inventive faculty that amounted almost to genius. As a man of science, he was among the foremost of his t1me, and recelved the extraordinary honor of an election to the Royal Academy without his knowledge and without any fee. It is, however, to bis 11terary gift that he owed the greatest part of his success. When he established a newspaper, he could easily write better than his competitors; when he wiohed to make clear a scientific experiment, he could describe it in print better than any of his contemporaries. The desire for money 18 the spur to success; it was eminently so in the case of Franklin: he labored, he starved, he contrived, for money. Above all and beyond all, his distinguishing characteristic was the com plete adaptation of the means for the accomplishment of the end to which he had set himself; to use a New England country phrase, so long as Franklin was "law honest," he did not trouble himself as to the precise moral signiflcance of a proposed line of action. "When you come to a low place, stoop," was a saying of "Poor Richard" and a cule of Benjamin Franki1n.30

Only in the last part of these comments 1s there any criticism even Implied. And judging from h1s laudatory comments, Chan ning must not have considered this too serious a flaw in "the first great American."

Channing relied rather heavily on Franc1s Parkman's works in his account of the Anglo-French rivalcy in North America, as all historians have done since that awthor wrote his memorable series. 31 The title of the first of Channing's

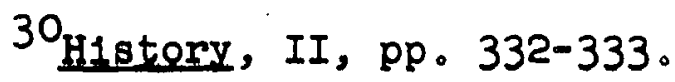

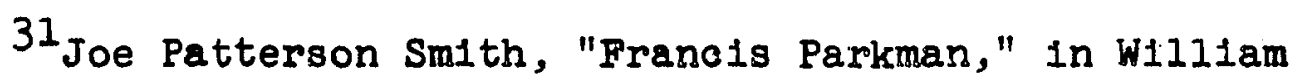
$T$. Hutchinson, ed., The Marcus $W_{\text {. Jernegan Essays in Amerloan }}$ Historlography (Ch1cago: University of Chicago Press, 1937), p. 56, noted that in one of Channing's three chapters on this 
three chapters on this struggle is revealing--"The Gallic Per11, 1664-1689." His point, made clear in this first paragraph, was that the threat was real:

In the spring of 1689 the opponents of the Stuart government in Massachusetts, New York, and Maryland ralsed the cry of danger from French invasion, danger from the alliance between the French and the Indians, and danger from the Roman Catholios. It has been the habit of historical writers to make light of these alarms and to regard them as party shibboleths which were used by colonlal agitators to further their ev1l designs or to hide their infamous doings. A careful consideration of all the facts leads 1rrestibly to the conclusion that the Gallic peril was more real than has generally been thought to have been the case. 32

One critic thought that Channing's treatment of the Anglo-French conflict was one of the few points in the H1story where he could be charged with "bias of the obvious, positive type." He called 1t Channing's "Anglo-Saxon mindedness"; 33 he had a point. The chapter title and paragraph just quoted are hardly free from a hint of bias; that Channing considered the area from Florlda to Canada to have been reserved by ood for the English and their kinsmen has already been noted. Here he continued the trend by referring to "the ineptitude of the Frenchman for colonial enterprise," by praising the French

subject he footnoted Parkman seven times and seven other secondary works a total of only eleven times. Interestingly, Channing commented of Parkman's Montcalm and Wolfe that it "must now be regarded as partialiy obsolete." (History, II, p. 600)

32 H1story, II, p. 131. pp. 298-299.

33 Ralph Ray Fahrney, "Edward Channing," Jernegan Esgays, 
Jesuits as individuals but emphasizing "the dangers of their doings" so far as the fate of the English colonies was concerned, by noting once again the "providential events" involved in the struggle, and by deeming it fortunate that French strength was "distinctly on the wane" by the time the showdown came. 34

Channing, of course, did not write the history of the great struggle w1th the color of Parkman, but his account is competent and readable. He justiflably aitached great 1mportance to the Treaty of Utrecht of 1713, though he was perhaps carried away when he sald 1t "may well be regarded as the beginning of the diplomatic history of the United States." Noting the major changes the treaty made--part1cularly British acquisltion of Acadia, Newfoundland, and the Hudson Bay reglon, and acknowledgement of the Iroquols as English subjects-Channing concluded that it "left the French nearly prostrate In Europe and America. They had almost reached the determination of abandoning their American colonies." But the French recovered very quickly, and by 1720 "were once more embarking on the path of colonial expansion." The major sign of this new v1gor was the fortiflcation of Loulsburg on Cape Breton Island. Brit1sh conquest of that stronghold, however, was the

${ }^{34}$ H1stony, II, pp. 131, 140, 142, 585. St111, he could praise an individual Frenchman: "Few figures stand forth in history in truer herolc proportions than does that of Robert Cavelier, Sleur de La Salle." (p. 133) 
highlight of the $1744-1748$ struggle known in the colonies as King George's War. The person responsible for that feat, Governor W1lliam Sh1rley of Massachusetts, recelved high praise from Channing as "one of the few remarkable Englishmen who occupled high office in America in that century." of that feat 1tself, Channing sald: "Few disasters in the elghteenth cen tury so overwhelmed the French with shame as did this catas trophe." But the Treaty of A1x $1 x^{-C h a p e l l e ~ r e s t o r e d ~ L o u i s b o u r g ~}$ to France. 35 The showdown was st1ll to come.

The showdown, of course, was the French and Indian War, 1754-1763. In Channing's account of that epochal conflict, which expelled France from North America, two 1ndividuals stand out. One is George Washington. To Channing h1s "dist1nguish Ing characteristics" were his "fair mindedness and military capac1ty," and he surpassed h1s pralse for anyone thus far in the H1story when he said:

of all men in history, not one so answers our expectations as Wash1ngton. Into whatever part of h1s. Ilfe the historian puts his probe, the result is always satisfactory. Washington was a strong, vigorous human being, with a strong, vigorous mind, and an amount of will power which was always equal to the task of compeliling his mind and body to perform the part to which Providence set them. 36

The other person who stands out in Channing's coverage of the war is Willam Pitt. With his coming to power in 1757, "a new chapter opened in the hlstory of England and America."

35 Ib1d., pp.543-549. again. 36 Ib1d., p. 559. Notice also "Providence" entering in 
He was a "remarkable man," who "possessed the 1maginative enthuslasm which marks the great statesman."

He was also fearless of criticism when he felt that what he was doing was for the benefit of $\mathrm{king}$ and country, wh1ch is one of the attributes of the man of power. He now infused some of his own falth and energy into military and naval commanders. Acting on the inltiative of others, he completely changed the policy of the empire as to America. Up to this time the 1dea had been simply to hold back the French; now, the plan was to expel them from the continent, and the difference was great. In carrying out this pollcy, P1tt also departed from tradition. He sought out the best men in m1l1tary and naval l1fe, regardless of their years, and gave them responsibllity and stood behind them. He concentrated English milltary and naval forces in America upon one fleld of activity at a time, abandoning for the moment the conquest of the West Ind1a Islands for the occupation of Canada. He recognized that the colonists could supply men and food, but could not unalded withdraw much labor and what was equivalent to cap1tal from ordinary occupations. He provided, therefore, that the colonists should pay the wages of the soldiers ralsed by them and supply them with arms and with clothing, but that all other expenses should be borne by the crown. In later campalgns the home government also provided arms, ammunition, tents, and part of the other expenses. The first result of the new policy was the capture of Loulsbourg in 1758.37

The final result was British victory as spelled out in the Treaty of Paris in 1763.

The same writer who berated Channing for his Anglo-

Saxon mindedness sald this: "The element of outright prefudice is most apparent where Channing had occasion to deal with the relations of the colonies to England." 38 This certainly

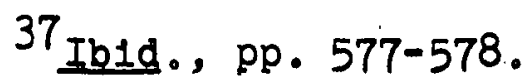

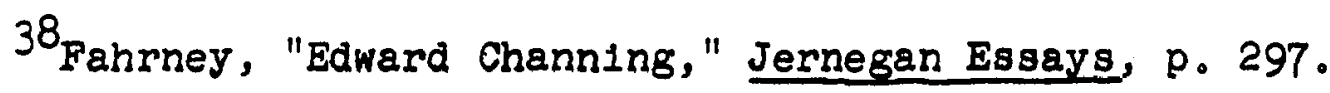


contrasts with the already once-quoted reviewer for the English Historical Review:

Between the mother country and the colonies he holds the scales fair, doing justice to Great Britain without falling into the exaggerated 1mperialism of some recent American authors. Though his heart is with the colonists he does not fall to point out their weaknesses, and though tracing in deta11 the record of English mismanagement he rarely exaggerates.39

Interestingly, one could lift material out of context from $\underline{A}$ Century of Colonigl H1story which would support elther of their views. However, the English h1storian was closer to the truth. In general, Channing treated the colonies as simply a part of the English imperial system and thus aligned himself with the Imperial School of colonial historians. Herbert I. Osgood and George Louls Beer, the two leading exponents of this approach, were both contemporarles of Channing. Indeed, the first volume of Osgood's major work appeared in 1904, the year before the opening installment of the Great Work. In only one way did Channing differ notably from these writers: he did find more opportunities to be sympathet1c to the American colonists. Channing's opening comments in this volume were also his Introduction to the topic of relations between England and her colonies:

The restoration of the second Charles to the English throne on the 29th of May, 1660, marks a turning-point in the history of the American colonies, as well as in that of England 1tself. King and courtiers returned from exile poorer in purse even than they were in morals; their financial needs

\footnotetext{
39w. L. Grant, Engl1sh H1stor1cal Rev1ew, XXIV (January, 1909), p. 146.
} 
determined the course of events in the next few years....

The king and his advisors at once seized upon colonial enterprise as one means of providing the necessary funds. They built upon the foundations of the Puritan time, and by a series of navigation acts monopolized colonial commerce in the interests of English subjects and the royal exchequer. They selzed Dutch New Netherland, and founded the colonies of Carolina and New Jersey. They interested themselves in the foundation of the Royal African Company, and in the company for the explo1tation of the fur trade of Hudson Bay 040

"The history of England and America in the next thirty years," he stated more emphaticaliy, "was determined by the necess1ties of these men, rather than by the1r avarice and moral turp1tude." 41

One of the most important results of the "necessities of these men" was, of course, the Navigation Acts Channing made it clear that pressure from the mercantile and industrial classes was also involved in their passage, but h1s comments continued to sound like a justification of the system:

In those days, merchants, land owners, and men of education were united in believing that the explo1tation of colonists for the benefit of the people of the mother country was right and proper. Such a policy does not indicate that they were actuated by a spirit of despotism or disregard of colonial interests, but simply that they were living in the days when the existence of colonies could only be defended on business grounds. Moreover, the system that comes to be outlined in the navigation laws and acts of trade was a system of intra-1mperial free trade and preference for English products, which reminds one of the policy of the United States two hundred and fifty years later.

\footnotetext{
40 H1story, II, pp. 1-2。 $4{ }^{4 \text { IbId., }}$. 5 .
} 
The underlying 1dea of the navigation system was to make the empire self-supporting and to confine the carrying trade of English lands to ships bullt within the empire, owned by the people thereof, and navigated by offlcers and crews who were subjects of the English king. Furthermore, trade in colonial products was to pass through England. 42

The Navigation Act of 1696 he justified specifically, saying that "colonial commerclal and governmental systems were sady in need of reorganization in the decade following the 'GlorIous Revolution." 143

Though he noted that "the meaning, even the phraseology of the navigation laws, was obscure," Channing felt they would have been "sufficlent for the carrying out of the policy of upbuilding English prosperity, could they have been enforced."44 But, "the colonists, despite the efforts of royal officials and admiralty judges, and often in coliusion with them, continued to carry on their commerce, greatly to the ir profit and in contravention of the navigation laws and other acts of the 1mperial Parliament." In another place he spoke of "1llicit trading on a large scale"; but he also acknowledged that, "Notwithstanding the recorded infractions of the trade laws, colonial commerce was much more restricted to the channels designed for 1t by Parliament than it had been in the earlier time."45

$$
\begin{aligned}
& 42 \text { Ib1d., pp. 8-9. } \\
& 43 \text { Ib1d., p. } 271 . \\
& 44 \text { Ib1d., p. } 251 . \\
& 45_{\text {Ib1d., pp. } 278,262,258 .}
\end{aligned}
$$


With the Sugar Act of 1733 , referred to now by most historians as the Molasses Act, Channing was not quite so kind, "The English statue book does not contain a more unjustifiable law relating to the colonies before the famous legislation which is assoclated with the name of George Grenville."46 It too, however, was constantly disregarded.

Channing wrapped up his coverage of the colonial commercial situation, and related 1 t to the general situation in 1760 , in these words:

Notw1thstanding the attempts to regulate colonial commerce,... the trade of the Northern Colonies was exceptionaliy prosperous in the years 1720 to 1760. Colonial vessels visited all parts of the Atlant1c seashore, but did not as yet pass the capes at the southern extremities of Africa and South Amerlca. In reading the commerclal papers of the American merchants of that time, one 1 s impressed w1th the dangers constantly to be expected from plrates, privateers, and rapacious offlclals; but one is equaliy struck by the absence of fear of the regular customs officers who were supposed to be enforcing the navigation laws and the sugar Act. Before P1tt's famous letter of 1760 it may even be doubted if merchants and tide-waiters were actualiy consclous of their duties and obligations; when they at length realized what was expected of them, rebelizion on the part of the colonists was not far off. 47

On the English commercial legislation specifically, then, Channing's comments were usually quite moderate. On other aspects of the mother country-colonies relationship, th1s was not always true.

$$
\begin{aligned}
& 46_{\text {Ib1d. . p. } 519 .} \\
& 47_{\text {Ib1d. , p. } 521 .}
\end{aligned}
$$


The year 1688 was, of course, a highlight in both the history of England and of her relationship to her North Amer1can colonies. The events of that year and those around $1 t$ were accorded extensive coverage by Channing in this volume. The major thing in the colonles themselves to recelve his attention at that time was the Dominion of New England. He made clear the Importance of both commerclal interests and the French threat in bringing about this forced union. He emphasized that "English mercantile interests were constantly puttIng pressure upon the English government to enforce the commerclal laws, and it was impossible to do this so long as the plantations were not directly under the control of the crown." And "The Imminence of danger from the slde of New France," he stated in another place, "was the one thing needed to induce James to take the final step of consolidating all the colonies north of Pennsylvania into one government...." 48

of the Dominion 1tself, and 1ts governor, Edmund Andros, Channing was very critical. "It is difficult to see how Andros adminlstration can be viewed in any other light than as an 1llegal despot1sm," he sa1d, "especially when one remembers that the comm1ssion 1tself was contrary to the laws of England, according to the opinion of the law offlcers of the crown." 49 Andros "possessed salr ab1l1t1es, but these were

$$
\begin{aligned}
& 48_{\text {Ib1d., pp. } 165,151 .} \\
& 49_{\text {Ib1d., p. } 180 .}
\end{aligned}
$$


coupled with an old-fashioned temper and an absence of tact which unfitted him for the performance of the delicate tasks to which he was assigned." He "exceeded his instructions," and he and his followers "used their power in a most unjust and Irritating manner."50 "The bane of English colonial management," he concluded, "has always been the tendency to apply principles of law and methods of legal procedure which had been developed in England to 1ts colonies, with a sublime disregard of the wishes of the colonists and of conditions which necessarily prevali in frontier settlements."51 Finally,

When tact and patience were needed, there was threatening and loss of temper; when quiet, strong action was required, there was vacillation and weakness. It was when the people were aroused to high indignation that news came to Massachusetts of the landing of W1111am of Orange on the coast of England on the anniversary of Guy Fawkes Day, November 5, 1688.52

The immediate result of that "high indignation" was the overthrow of Andros.

Here 1s Channing's summary evaluation of the Glorlous Revolution and 1ts effects on the colonies:

The Revolution of 1688-89 was a Wh1g-Dutch conquest of the English emplre caref'ully concealed under constitutional contrivances. It confirmed to Englishmen rights and liberties for which the Pur1tans had struggled in vain. For the colonists the Revolution meant nothing of the kind. Their consent to the change of dynasty was not asked, their

50 Ib1d., pp. 53, 183.

51 Ib1d., p. 184.

52 Ib1d., p. 185. 
interests were not considered; they were simply ordered to proclaim the new monarchs. The effect of the Revolution was to hand them over to the English land-owning oligarchy to be exploited for the benefit of English Industry. The remedial statutes which made the movement memorable in English constitutional history did not extend to the colonies. Moreover, the new government exhibited an energy in colonial administration which the Stuarts had never shown. After 1689 the colonists were in a worse plight thap they had been in the relgns of Charles and James. 53

Though Channing noted the "energy" of colonial policy after the Glorious Revolution, he also stated that William and his advisors came up with nothing new:

The new rulers of England might well have recognized their partisans in the plantations and have rewarded their falthfulness to "Revolution principles" by continuing them in the possession of those governments which they had wrenched from James's adherents. Instead of so doing, William and his advisors proceeded on the assumption that colonists followed the condition of the mother country and were as amenable to misrule after the overturn in England as they had been before 1 t. In place of inaugurating a new pollcy, they merely reorganized the colpnial administration on the lines of the old system.54

Rather strange, if William did nothing more than

restore the old colonial system, that Channing would condemn his policles so strongly. "By a wise use of the opportunities which events had placed in his hands," Channing wrote, "W11liam might have laid the foundations for lasting concord between the two great portions of the English people; but the outcome was quite different." Noting the inclination of historians

$$
\begin{aligned}
& { }^{53} \text { Ib1d., pp. 189-190. } \\
& 5^{4} \text { Ib1d., p. } 213 .
\end{aligned}
$$


to condemn George III and "the stup1d, 1gnorant pol1t1c1ans" in control during his relgn for causing the Amerlcan Revolution, Channing concluded that "the causes of that cataclysm I1e farther back and may be largely found in the settlement of the 1mperial constitution in the years immediately following w1lliam's accession to power." 55

Channing seemed to condemn English colonial policy for faling to realize that "ever since the Restoration, colonial institutions had been developing in a direction contrary to those of England." He wrote:
All the English settlements along the coast were rapidly growing in population and in wealth. The words "oolonies" and "plantations" hardly describe the1r clrcumstances. Nevertheless, Englishmen in England st111.regarded them as settlers and as sub- jeots of England; Englishmen in the colonles looked upon themselves as possessing the rights of English men, wh1ch had been guaranteed by Magne Charta and a long succession of memorable statutes. The former regarded the colonial governments as publlo servioe corporations; the latter 10oked upon them as having the same attributes as the government of England. The former regarded the colonial assemblies as sim1- lar to the oounc11 of an Engl1oh o1ty; the latter looked upon them as possessing powers similar to those whigh were exerolsed by the Eng11sh House of Commons. 55

Channing gave a critical interpretation of colonial governors which has been greatly mod1fled by more recent historlans. "Had the governors been persons of foroe, independent means, and character," he sald, "they would have exerolsed an

$$
\begin{aligned}
& 55_{\text {Ip1d., p. }} 219 . \\
& 56 \text { Ib1d., pp. } 222-223 .
\end{aligned}
$$


Important influence upon colonial life and const1tutional development. Fortunately, they were usually persons of quite opposite qualities...." Lord Cornbury, governor of New York, came in for the strongest condemnation. "Of all the governors who brought English authority into contempt in the colonies, none was more thoroughly disreputable" than he, thought Channing. "He was a spendthrift, utterly dishonest, and without morals。"57 The chapter ent1tled "Beginnings of Const1tutional Cortroversy" is primarily a recital of the confilets between governors and legislatures in the colonies; it makes for some of the most drab reading anywhere in the Great Work. Channing wrote to Brett in 1906 that he was at work on both volumes II and III and that he was putting into the latter "as much constitutional matter as possible in order to lighten the second rolume of this somewhat heavy reading." 58 So far as readablilty 1 s concerned, one can only wish he had lightened this volume of that type material st111 further. Let this brief summary statement on the colonial executive-leglslative clash suffice:

John Locke lays down the general proposition that in any government the legislative is supreme. The actions of executive authority frequentiy attract attention by reason of their brililancy; but the slower-moving legislative in the end accomplishes its purposes and usually at the expense of 1 ts more spectacular partner. The history of the e1ghteenth century in the colonies is pecullarly 1llustrative of this proposition. The assemblies represented colonial desires in opposition to English control.

57 Ibid., pp. 247,308 . ${ }^{58}$ Channing to Brett, May 7, 1906, Macmilian Collect1on. 
They constantly gained power from the executive by the good old English method of tightening the grip on the strings of the purse, being greatly assisted thereto by successive French and Indian Wars, which placed the governors in constant need of money and compelled them to accede to demands in deflance of orders of $\mathrm{king}$ and proprietor. 59

In the final paragraph of A Century of Colonial His-

tory, Channing related the acquisitions of territory through the Treaty of Paris in 1763 to the general colonial situation, and concluded:

With this great accession of colonial interests a new chapter opened in the history of the British colonial empire. Would the rulers of Britaln continue to permit the people of the continental colonies to develop their industries and their institutions with the minimum of control, or would they establish effective governments in them and strive to make them directly contributory to the imperlal treasury? Upon the answer to this question depended

\section{H1story, II, p。282. In another place, Channing} stated it slightly differently, and also hinted at the predominance of commercial factors in the English-colonlal rivalry, of which he was to make a major point in volume III: "From the English Revolution in 1688-89 to the American Revolution in 1775-83, the constitutional development in all the royal and the proprietary provinces was substantially the same. Everywhere the Assembly clatmed for 1 tself the powers and privileges of the House of Commons, and everywhere $1 t$ denled that the Counc1l bore any resemblance to the House of Lords. Everywhere the Assembly used 1ts control of the purse to com pel the representatives of English authority to disobey his instructions, or, at all events, to pay no regard to them. The mode of compulsion varied slightiy in the several colonies, owing to the different constitutional arrangements that prevailed in them: in Massachusetts the salary of the governor was the matter about which the contest was waged; in New York the levying of taxes in general; in Pennsylvania the paying tribute to the proprietary. It made little difference whether the governor represented king or proprietor; everywhere the colonlsts demanded greater control of their affairs than the governor's instructions permitted. How strenuously the authoritles in England would have insisted on their constitutional rights may well be doubted had not the enforcement of the Imperlal commercial system been more or less involved in the control of the colonial government." (pp.248-249) 
the future of the British emplre... Community of race, language, religion, institutions must be present in the make-up of a nation. The people must be of one racial stock; they must have a comson mode of speech; their religious aspirations must find expression in common lines; their institutions for government and for the protection of person and property must be substantialiy similar. In 1660 the people of England and of the English colonies in North America may be said to have formed parts of one nation; in 1760, this was no longer true. The absorption of Dutch New Netherland, the great flowing in of Immigrants from Germany and from France and the Importation of thousands of negroes from Africa had given to the colonies racial elements that were not present in England. Moreover, although there was as yet no considerable amalgamation of the white elements In the colonial population, it may be said that changed climatic conditions and environments had already begun to alter the racial characteristics of the descendants of the first comers from England. rel1gion in England, the church establishment had bound 1tself more firmly to the State; while in America, dissent had thriven under radical conditions of living- not one colonist in forty owed fealty to the colonial representative of the Established Church of England. Above al1, colonial 1nstitutional 1deas had developed on lines which were opposed to those prevalilng in the home lands. Finaliy, the commer clal interests of the two great divisions of the British empire were now distinctly different. In all that constitutes nationality, two nations now owed alleglance to the Brit1sh crown. The colonists were patient and long-suffering; only prolonged misgovernment on the part of the rulers of Britain compelied them to declare themselves fndependent of that empire from which they had sprung. 60

In that final statement, Channing cast all caution to the winds. Even the reviewer for the English Historical Review who pra1sed Channing for his moderation was offended. This was an oplnion, he sald--more moderately than Channing--which "cannot be fully justified." 61

${ }^{60}$ Ib1d., pp. 598-599.

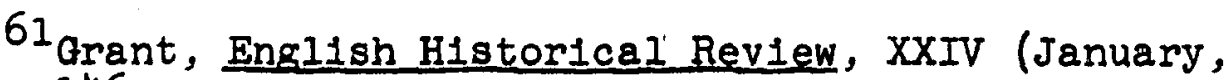
1909), p.146. 
By far the most perceptive and useful review of this volume was the one in the American Historical Review. Though the reviewer's reaction to the volume was basically favorable, he felt that there were four major critic1sms. F1rst, Channing was "not free from prejudice." Second, there were some major omissions which were difficult to Justify. Third, Channing betrayed "a certain insularity in his frequent insistence or. the impotence of the home-government and the futility of the system established for the control of the colonies." And finaliy, he felt that Channing had "falled to give his treatment either unity, purpose, or depth." Each of these was wellsupported with specific examples. Minor flaws noted were the fact that Channing seemed pleased if he could t1lt everything in favor of the colonies, and several minor errors of pact。 62

Even Channing's grandson admitted that it was "a fair and exact evaluation" to say that this volume did not possess unlty, purpose, or depth. Though he correctly considered it

\section{Amer1can H1ston1cal Rev1ew, XIV (January, 1909),} pp. 364-366. Perhaps it would be approprlate here to glve one example of each of these four points. Channing's attitude toward the colonial governors was c1ted to show h1s prejudice. The fact that he sald "practlcally nothing" of "the detalls of British cnntrol from 1660 to $1696^{\prime \prime}$ was considered a serlous error of omission. The chapter on "The Reconstructed Colonial System" 1llustrated the third criticlsm. And finally, the revlewer elaborated thus on the lack of "un1ty, purpose or depth": "We cannot see that his narrative moves for'ard to any culmination. We should naturally expect to find ourselves at the end of the work ready to understand better the causes of the Revolution, but we cannot see that anywhere Professor Channing has sought to meet this expectation or has made any at tempt to search for causes. Progress is noted here and there, but that general movement which marks the development of ali the colonies taken together seems to lie altogether outside the author's interest." 
"one of his most perfect volumes on the basis of sclentific scholarship," he believed its inclusion of "so much petty detail" an "outstanding negative quality。" "Fallure to integrate the governmental with the social, industrial and religlous aspects," he continued, "Ieaves this book in a condition from which only a research scholar on colonlal government can glean the real value." He thought Channing was at his best in this volume when he dealt with the industrial, soclal, and religious history of the colonies. 63

Once again, however, no review was generally critical In tone. Essentially favorable reviews appeared in the Nation, Dial, the Outlook, the Amerlcan Review of Reviews, the American Library Association Booklist, the Independent, and the Annals of the American Academy of Political and Soclal Sclence. The latter sald that the first two volumes together established for the work "a secure place among the histories of the United States." To the Independent, Channing's work gave promlse of being "the most 1mportant history of the United States since George Bancroft's."64

\section{Fuller, "Edward Channing," pp. 114-116.} 64 Nat1on, IXXXXII (November 5, 1908), pp. 440-441; st. George Leakin S1oussat, D1al, XIVI (May 16, 1909), pp 327329; H. Addington Bruce, Outiook, XCI (March 27, 1909), pp.753754; American Rev1ew of Reviews, XXXIX (February, 1909), p. 251; A. L. A, Bookl1st V (February, 1909), p. 36; Independent, IXVV (November 12, 1908), pp. 1122-1123; and Emory $\mathrm{R}_{\text {. Johnson, Anna18 }}$ of the American Academy of Political and Soc1al Science, XXXIII (March, 1909), pp. 245-246. 
I have been reading for Vol. III the last few weeks. The writing that wil1 be a pleasure and I ought to be able to do a humming good plece of work especially if I can get freshened up a bit. 1

Edward Channing spent the summer of 1908 in research and relaxation in Europe. He wrote to George P. Brett on September 2 that he was back after "a very enjoyable tr1p." Though he showed a disinclination to begin concentrated work on volume III of the Great Work, saying that he was "feeling very poor just now," he had done so by January, 1909, for that month he went to New York for research. And, as usual, once he had begun to concentrate on a project, he was loathe to be 1nterrupted. He responded to Cerl Russell F1sh's ouggestion that he come to the UnIversity of W1soonsin to deliver a serles of lectures by 11st1ng the reasons why he oould not do so. He had no time except the m1d-year per1od, he sa1d, which did not correspond with the detes open at Medison. The second reason was "a rooted dislike on my part to the Amerloan Puliman sleeper which almost 1nvarlably means a bad cold, at least, to me. I can stand a day's travel well enough," Channing continued, "even in the super-heated parlor cars; but the sleeper 18 one

IEdward Channins to George P. Brett [President, Maomilian Company], Apr11 26, 1908, Edward Channing F110, Maomilian Authors Coliection, Manuseript Divio1on, New York Publ10 Library. 
too many for me." And finally, most important of all, "there is a great desire on my part to push the nork on volume III of my history...." With such single-mindedness as this, Channing was able to write his publ1sher on June 15, 1912 , that the volume was written.2 It was published in september. Channing established the key-note of this third volume on the very first page. "Commerclalism," he said, "the desire for advantage and proilt in trade and industry, was at the bottom of the struggle between England and America; the 1mmutable principles of human association were brought forward to justify colonial resistance to British selfishness." He continued: "The governing classes of the old oountry w1shed to explo1t the American colonists for their own use and behoof; the Americans desired to work their lands and carry on the ir trade for themselves." 3

Several of the 1deas 11lustrative of the concept that two nations had developed within the Brit1sh Emplre by 1760 were repeated here by Channing. Raclal, political, rel1gious, soc1al, economic, and educational differences between England and America were all mentioned, then Channing emphatically concluded of the colonists:

2Ib1d., September 2, 1908, and January 26, 1909; Channing to Carl Russell F18h, June 13, 1910, xerox copy from Carl Russell Fish Papers, State Historlcal Soclety of Wisconsin, Madison; and Channing to Brett, June 25, 1912, Macmilian Collection.

3Edward Channing, A H1story of the United States. Volume III: The American Revolution, 1761-1789 (New York: The Macmilian Company, 1912), pp. 1-2. 
They already had a large measure of self-government and were determined not to part with one jot or tittle of 1t. At the close of the French and Indian War there were no more loyal subjects than the Amerlcans; but they felt their own importance and strength. They resented the constantly reiterated assertions of despotic power on the part of unreformed parliamentarians and an unreformable king. They dreaded the ever tightening grasp of the custom-house upon their trade and their means of IIvelihood. They felt that the government was careless of their rights and unfrlendly to their further growth toward the west. 4

James Otis and the writs of assistance controversy and Patrick Henry and the parson's cause eplsode recelved some emphasis from Channing in his opening pages. Channing quoted Ot1s' famous saying, that "Government is a conditional compact between king and people....A violation of the covenant by either party discharges the other from 1ts obligation," and Henry's more famous words, that "An Act [of Parliament] against the Constitution is vold," then concluded:

In these thirty words Patrick Henry and James Otis denied the divine orlgin of the British kingship and the legislative supremarcy of the British Parliament, and substituted therefor the Common Law and other eternal rights of man. Moreover, these phrases shadow forth the reason for the secession of the old English North American colonies from the British Emplre and the princlples which underlie our own system of government to th1s day. 5

Channing realized, however, that these 1deas were by no means new. John Looke had made the most important statement of th1s philosophy before Americans adopted 1t. In the second

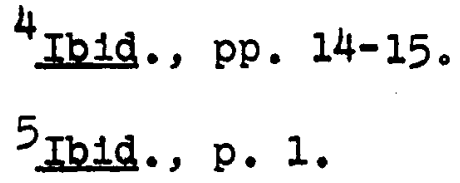


of his "Two Treatises of Government," sald Channing, he "set forth the glittering generalities that became the political gospel of the American revolutionists." American statesmen, he sald, simply "combined these 1deas with the practical know ledge which they had gained in their political careers," and then proceeded to enunclate "a theory that was incompatible with the ideas of emplre as they were then held by Englishmen。"6 Channing was mildiy critical of the British government's Proclamation of 1763 , noting that "The fact that the reserved territory for the most part lay w1thin the chartered limits of the older colonies does not seem to have occurred to those who drew up this proclamation." He concluded his first chapter by emphasizing that "the years 1760-1763 were epochal, for in them may be discovered the beginnings of the movement which was to make the next ten years so memorable."17

In the general b1bllographical comments at the end of the flrst chapter, Channing made interesting brief evaluations of some Important historlans. W. E. H. Leoky's History of England in the E1ghteenth Century and Sir George Otto TreveIyn's American Revolution, Channing considered to "stand preeminent for the1r point of view, the1r general falrness toward America, and the historical insight of their authors; but," he rather paradoxically continued, "both are unfair to the men who mismanaged British affalrs in that epoch in requiring of

\footnotetext{
Ibid., pp. 10-11.

7 Ib1d., pp. 22, 24 .
} 
them standards of our day and not of their own time." John Fiske, C. H. Van Tyne, and Sydney George Fisher all recelved moderate praise from Channing, but George Bancroft was rather soundly condemned. H1s volumes were "so clouded by the author's democratic prejudices that one hesitates to accept his judgments," sald Channing. "He did a vast amount of work in collecting manuscripts and correlating them; but oftentimes seemed unable to understand the lessons which they should have taught." 8

Despite Channing's criticlsms of Bancroft, one would be hard-pressed to come up with a more incautious comment from that great nineteenth century historian than Channing himseif occasionally made. Only a few pages after derlding Bancroft so, Channing was writing thus of King George III: "The modern American student sees in the third deorge no mere tyrant, no m1sguided monarch, but an instrument of a benirn providence bringing, through pain and misery, benefit to the human race." Hardiy a statement one would expect from a purely sclentific twent1eth century historian! Some of his other comments on that soverelgn were only a little less harsh:

He was a politiclan, shrewd and unpltying, whose whole ambition was to place the kingship back where it had been in the days of the early Stuarts.... Permanent mental incapac1ty found him st11l firm in

8 Ib1d., p. 26. Channing had also written of Bancroft in a similar vein in volume II. Bancroft's works, he said, were written from the sources, "but the author was so prejudiced in favor of theoretical democracy that his comments upon the facts must be recelved with caution."--Edward Channing, $A$ History of the United States, Volume II: A Century of Colonial H1story, 1660-1760 (New York: The Macmillan Company, 1908), p. 27 . 
the belief that he was right and always had been, and all the rest of the world was wrong....He permitted his ministers to establish a new colonial policy that could have but one termination. Looking backward, it is clear that the interests of Great Britain would have been best served by the abandonment of all petty restrictions in colonial government and trade and by bullding up American commerce and industry.9

Channing alleviated the severity of the condemnation 1mplled In the latter part of these comments, however, when he cont1nued:

Seldom is a nation endowed with rulers of such certain judgment, of so prophet1c 1maginations, and courages commensurate to the inauguration and prosecution of so broad a policy as th1s. Meeting the demands of the hour as they arise is the ordinary Iife of a potion, nor ought the historian to expect otherwise. 10

In addition to treating George III rather severely, Channing came to the defense of the colonists quite frequentIy. "The Americans felt that they were already overburdened with taxat1ons" in 1764, he noted, and went on to make 1t clear that he agreed that they were. After the passage of the Revenue Act of 1764, now ordinar1ly known as the Sugar Act, colonial trade and navigation were "In a stra1ght-jacket," according to Channing, and "the American radicals were quite justifled In their outcry." He sald of the Quartering Act of 1764 that, even granting that 1t was necessary to keep Brit1sh troops in the colonies and require the colonists to support them, "the

9 History, III, pp. 30-31.

10 Ib1d., p. 31 . 
working of this particular law was unjust." He referred here specifically to the disproportionate burden New York was forced to bear. "To ask them [the colonists] to subm1t to new levies imposed upon them in what they regarded as an 11 legal manner at the precise moment when their trade was being restrained," said Channing in building up to the Stamp Act of 1765, "was altogether too much."ll The person responsible for much of the legislation of this period Channing soundly condemned:

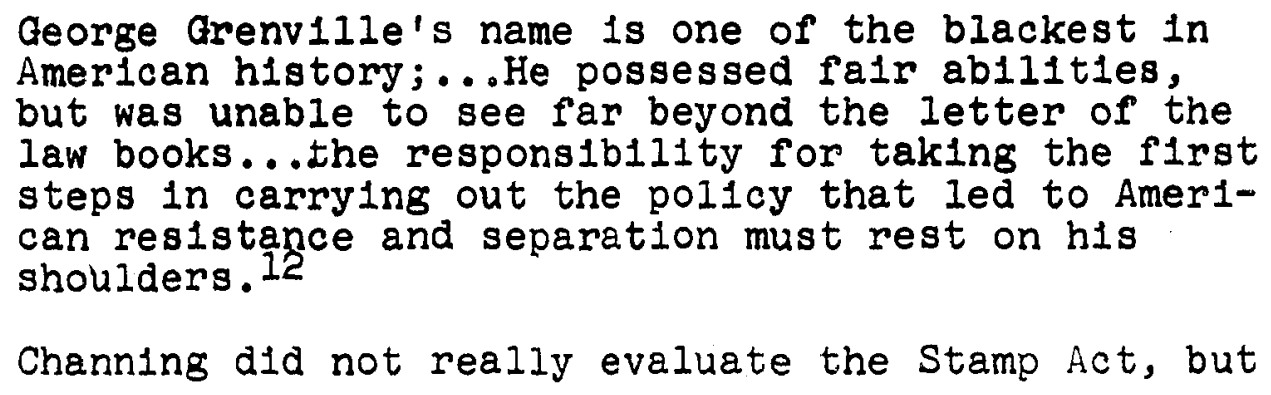
h1s att1tude was already quite clear by that point. He did attach great signiflcance to the Stamp Act Congress as "the flrst general assembly to be held by concerted colonial action without any prompting from royal officials. It pointed the mode for combined extra-legal resistance"; he continued, "1t proved to be the forerunner of other continental congresses, and thus fully justified the declaration of the Lords of Trade that it was a precedent of 'dangerous tendency." Channing also made the Virginia Resolves of 1765 , Introduced by Patrick

$$
\begin{aligned}
& 11_{\text {Ib1d., pp. } 32,42,44,45,47 .} \\
& 12_{\text {Ib1d., p. } 38 .}
\end{aligned}
$$


Henry in opposition to the Stamp Act, sound more 1mportant than historians ordinarily have done. "They were, indeed," he sald, "the 'alarm Bell to the disaffected,' the spark that was needer to light the fire of discontent throughout the land."13

Channing emphaslzed that the Stamp Act was almost never enforced. He sald that "the number of instances in which the act was obeyed was so small that to all intents and purposes 1 t was a dead letter from the beginning." He made the radical associations known as "Sons of Liberty" sound 1mportant in the opposition movement, and noted that the movement was so effective that British manufacturers and merchants began to pressure Parliament to repeal the objectionable measures. This was done, of course, but, according to Channing, the "arrangements for extracting funds from colonial consumers" made at the same tIme, together w1th the Declaratory Act, stating that Parliament had the right to legislate for the colonles "In all cases whatsoever," "more than did away with whatever of concession there may have been in the repeal of the Stamp Act." 14 He continued:

W1th an Ignorance of English conditions that is comparable only to Englishmen's lack of knowledge of American affairs, the colonists rejolced greatly over the repeal of the Stamp Act. In their eyes, George III and W1111am P1tt were deliverers from bondage. The New Yorkers voted statues to both. P1tt, in a toga, was carved in stone; George, on horseback, was

\footnotetext{
13 Ib1d., pp.57-58, 55-56.

${ }^{14}$ Ib1d, , pp. 62-65, 78 .
} 
cast in lead and brass and richly gilded. Really, the repeal of the stamp Act settled nothing. Unconsciously, the American people had come to the determination to pay no more money levied by parliamentary grant. Many a stupider man than George Grenvilie and many a lighter headed man than Charles Townshend might well have been put on the ir guard by Franklin's answer to the inquiry whether the colonists, by the same line of reasoning which they had advanced aga1nst the stamp Act, might not likewise object to external taxes levied by parliamentary law. "They never have hitherto," the ph110soph1c statesman replied, and continued, "Many arguments have been lately used here to shew them that there is no difference,.....At present they do not reason so, but in time they may possibly be convinced by these arguments."15

Once again, with the year 1765, Channing stepped aside from the narration of events to generalize on the relationship between England and the colonies. He began by discussing a few of the great deluge of tracts written at the time and wound up admitting it was technically correct that, "under the British form of government, Parliament was supreme in the empire. Nevertheless," he continued, "the unrepresentative character of the Commons, using that word in 1ts ordinary sense and not In its technical constitutional meaning, was patent to the colonists and to many good people in England as well." He was quite willing to acknowledge the impracticality of the colonial position on "taxation without representation." "In point of fact," he wrote, "under the broad colonial declaration that no one could be taxed who was not personally represented, no leglslative assembly that ever existed could rightfully levy

${ }^{15}$ Ib1d., pp. 78-79. 
a tax."16 Channing was also careful to note the different understandings of "taxation without representation" which prevailed in mother country and colonies:

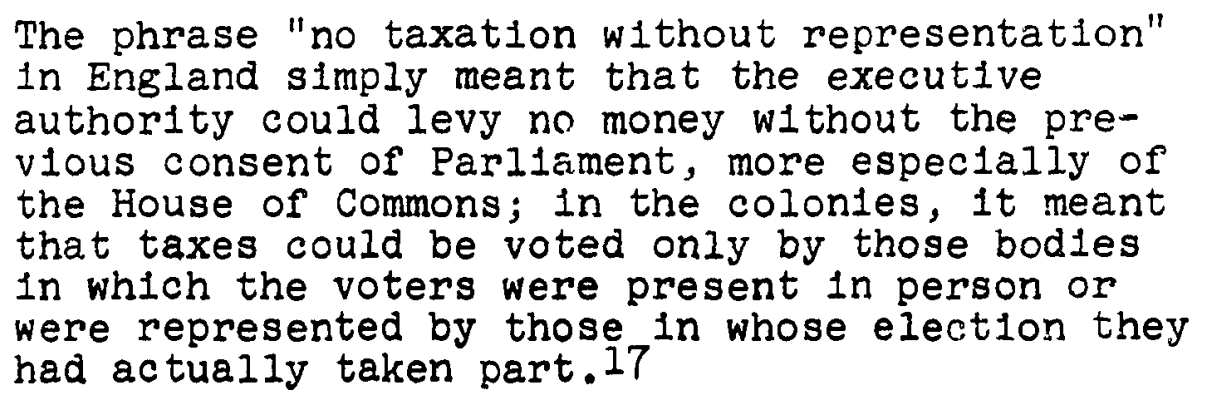

He then reiterated his 1dea that, "In this respect, as in some others, colonial institutions had drifted so far away from those of the home land and had become so uniform in their principal characteristics that the colonies may well be considered as already forming an embryonic nation."18

Charles Townshend and his colonlal policy recelved critical treatment from Channing's pen. Channing referred to the "obloquy" which Townshend's actions had attached to h1s name, and concluded of the policies inaugurated by him:

The new system was successful in that 1 t enabled a swarm of offlceholders to live on the frults of colonial labor and industry. It was disastrous because it led to rlot, rebelilon and revollition. 19

Channing thought the Massachusetts Circular Letter ep1sode, which ended in dissolution of that colony's

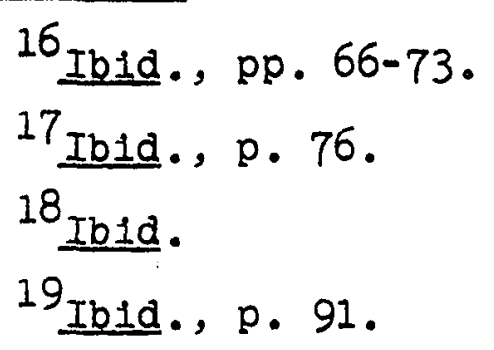


representative assembly, was "another example of the 1gnorance of the English government as to colonial conditions which goes far to justify the contention of the colonists that they could not be properly governed from London and must therefore rule themselves." 20 He saw the Boston Massacre as the last straw:

On March 5, 1770, the very day on which Lord North moved the repeal of the duties on English manufactures, an affray occurred in the streets of that town which clearly showed that nothing less than a radical change in policy could avert the impending conflict between Great Britain and her thirteen colonies on the continent of North America, - no halfway measures of "conclilation" would suffice.21

Channing had a sure touch when dealing with the commerce of the colonies in the revolutionary era, and he contributed much that was new. He knew th1s, and was proud of 1 t. He wrote to Brett in 1909 that he was "poring over some old custom house accounts which I came upon by chance and which are unknown to every other writer and w1ll give...my third volume a unique position in narratives of the American Revolution."22

One Interesting ep1sode shows how Channing came up with some of this information, and sheds light on his research methods and personallty as well. He recelved the income from the Woodbury Lowery Fund for a two-year perlod beginning in

\footnotetext{
${ }^{20}$ Ib1d., p. 99.

$21_{\text {Ib1d., p. } 113 .}$

${ }^{22}$ Channing to Brett, February 8, 1909, Macmilian Collection.
} 
1910. Th1s amounted to approximately $\$ 2,040$, and was used "to assist him in prosecuting researches into the trade relations of Spain with the British Colonies, before the Revolutionary War."23 Lowery's s1ster, the Duchess de Arcos, was the admin1strator of the fund. Channing wished to thank her for the gift, but was doubtful as to the proper approach. "I am somewhat at a loss how to address such a lady and should be obliged to you If you would state how an envelope should be addressed and also how I should begin my note," he wrote to President A. Lawrence Lowell, who had helped secure the money for h1m, "all this because I am not in the hablt of writing to duchesses."24 Archibald Cary Coolidge, another member of the Harvard history department, Indicated in a letter to Lowell that there was a possiblilty of resentment over Channing's recelpt of the money, and seemed to show a little himself. He thought the graduate school should profit from the money, but indicated the matter should at least go before the department as an "open question." "Channing has not the reputation of being altruistic," he expla1ned, "and if it were to appear that he had profited by inside information to secure this fine windfall for his own exclusive benef1t...there might be a good deal of bad feeling." 25 Channing apparently used the money to hire someone

23 A. Lawrence Lowell to the Duchess de Arcos, December 9, 1910, in the Edward Channing folder of the A. Lawrence Lowell Papers, Harvard University Archives, Cambridge, Massachusetts. 24 Channing to Lowe11, November 7, 1910, Ilde. Ib1d. 25 Archlbald Cary Coolidge to Lowel1, June 24, [1910?] 
to look up the information he desired, a method which he frequently employed.26

Continuing his narrative of events leading to revolution, Channing noted that the years 1770 to 1773 , from the Boston Massacre to the Tea Act, were a relatively calm period In the relationship between Britain and her restiess colonies. At least one man, however, worked continually to keep it from being so. Samuel Adams, sald Channing, "was distinctiy a man of the people, gifted with incomparable tact in banding toge ther the discontented, and endowed with consummate ability in setting forth in written page the aspirations for liberty that impelled the masses." He had "an almost unparalleled cogency of style." But Channing recognized that Adams alone could not have done the job:

Viewing the chain of incidents leading up to the separation from England, it is evident that Samue 1 Adams was unalterably opposed to any tightening of the Imperlal bond, and wished for increased colonlal self-government and probably for separation from the mother country. It is also perfectly clear that he could not have forced the issue, no matter how much he might have wished to. That was the work of self1sh placemen in England, whose horizon was bounded by the narrow seas of their own 1siand, and of over-zealous and stubborn officials in America, whose thoughts were ever intent upon places and pensions, --Townshend, H111sborough, and Lord North in England; Hutchinson, Dudingston, and Tyron in Amer1ca. W1thout the1r ald, not even the superhuman powers that have been attributed to

26 Another example of a similar procedure was his hirm ing of a person to copy some information relating to commerce in St. Augustine, Pensacola, and New Orleans (Channing to $\mathrm{J}$. Franklin Jameson, November 23, 1912, John Franki1n Jameson Collection, Manuscript Division, Library of Congress, Washington, D. C.) 
Samuel Adams by his enemies and his blographers could have brought about the crisis of April 19, 1775.27

Specifically, Adams was aided by the Gaspee affair, and then, most of all, by the Tea Act, by which "the public mind was excited to a greater degree than at any time since the Stamp Act irritation." Channing felt that colonial resentment against British measures reached a peak with the passage of the Boston Port Act in 1774 to punish Bostoners for the Tea Party。 "Never before in American history," he stated, "and posslbly never before in any history had the waves of sympathe tic enthusiasm mounted so high as those which now rolled from South to North and from North to South." Channing did not apply the now-accepted name "Coerclve Acts" to the serles of measures passed by Parliament in 1774 , but he recognized the1r Importance, and the signiflcance of the Quebec Act being assoclated with them in colonial thinking. "Already irritated by the Gaspee 1nquiry and by the laws for punishing the New Englanders, the colonists were annoyed and exc1ted by this attempt to curb the1r further growth," he sald of the Quebec Ast. The culmination of this excitement was the First Continental Congress. Channing emphasized the basically conservative nature of this body, and sald 1ts most important work was the adoption of the non-importation, non-exportation, non consumption agreement known as the "Association."28

$$
\begin{aligned}
& 27_{\text {H1story, }} \text { III, pp. 122-123。 } \\
& 28 \text { Ib1d., pp. 130,136,142, 145-147。 }
\end{aligned}
$$


If this seems like an over-brief summary of the cruclal years 1770 and 1775 , it is because Channing's own account of this period was so compact. Indeed, much of this volume up to the outbreak of the Revolution is indicative of Channing's Inclination to skim rapidly over materlal, regardiess of how Important, when he felt he had nothing new on 1t, and, concomitantly, to go into deta1l on lesser-known things where he did have a contribution.

Channing's chapter on "The Cris1s, 1775" 1mpresses the reader with 1ts calm, dispassionate tone, and with the author's abllity to make military history understandable to the general reader. One historian, comparing Channing's account of the confrontation at Lexington with George Bancroft's, concluded that the former's was "In conform1ty w1th the known facts," while the letter's was not. 29 Channing's simple description bears repeating:

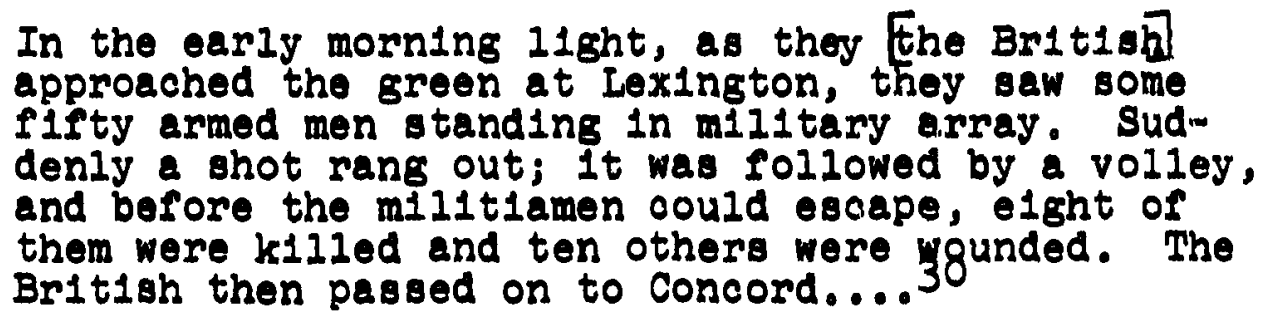

Note that Channing d1d not even venture to speoulate as to who flred that famous "shot heard 'round the world"!

29 Watt Stewart, "deorge Bancrort," in W1111am T. Hutchinson, ed., The Marous W. Jernegan Essavs in American H1stor 1ography (Ch1oago: Univers1ty of Ch10ago Press, 1937), p. 19.

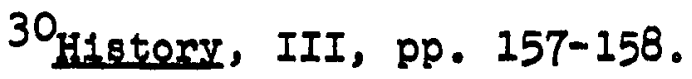


Channing also showed an ab1lity to dist1ll the essence of a battle into a single sentence. "The stand made by the colonists at Bunker Hill," he sa1d, "aroused a sp1rit of exultation throughout the continent, which was not at all lessened by the fact that, in the end, the1r troops had been obliged to retreat." of the first three armed encounters, he sald:

"Lexington and Concord and Bunker Hill declded the matter; there could be no going back."31

"The determination to coerce the colonists was the more read1ly reached because no stiff resistance was expected," Channing noted. "The Amerlcans were looked upon as cowards by those high in office" From this observation, he went on to make an important point about the Revolution as a whole:

These opinions reflected the contempt of military men for cltizen soldiery in the day when tactics demanded that opposing armies march slowly toward one another and fire into each other's faces. The colonists had learned a different mode of warfare, more sulted to a broken and forested country. Whenever possible they got behind trees or logs or sheltered themselves in a hole in the ground and shot down the first enemy who came within range. In Europe, war was a profession; in America it was only waged for life and famliy. Before the conflict ended there was something plaintive in the complaints of Englishmen and Cermans that the Amerlcans fought like savages, - - the frontler had taught them a more modern method of warfare. 32

In Channing's chapter on the Declaration of Independence, he was at his best. He noted that up to 1775

$$
\begin{aligned}
& 31_{\text {Ib1d., pp. } 172,170 .} \\
& 32_{\underline{\text { Ib1d. }}, p_{0} 172 .}
\end{aligned}
$$


"Independence was outslde of practical American politics." "The colonists were not at all opposed to monarchical inst1tutions, nor were they hostile to the British kingship," he continued. "They had outgrown the colonial condition and desired to be permitted to govern themselves or to be given a share in the imperial counc1ls on an equal footing with the dwellers in the parent state." Polltical leaders in" the mother country had no thought of Independence elther; they were "un1ted in proclaiming the colonists to be subjects of Great Britain and absolutely dependent on the leglslation of 1 ts ParIlament." Thus, though they did not yet recognize 1t, "Both sides had reached the polnt where nelther could give way without abandoning 1ts whole case."133

The tide turned quickly in 1775. The king helped; he "made measures palatable [to the colonists] which hitherto had seemed quite out of the question," by his crass negative response to the "Olive Branch Petition." But Thomas Paine helped even more; he was "one of those literary splrits whose birthright is the faculty of influencing their fellow men in writing and in print," and his pamphlet entitled "Common Sense" "unquestionably converted thousands to the necessity of separat1on."34 The sentiment for independence then spread, through the army, the states, and the Continental Congress 1tself. The

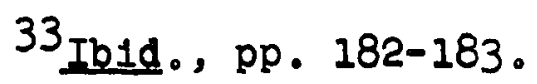

34 Ib1d., pp. $187,189-190$. 
final result was the Declaration of Independence:

Never in the whole range of the writings of political theorlsts has the basis of government been stated so succlnctly. The ldeas are drawn directly from Locke, the words are generally his, sometimes whole phrases are taken from the "Second Essay of Government," but the reader w111 go to Locke In vain for so lucid a statement of his 1deas. Jefferson possessed the faculty of combining words in phrases that remain in one's memory throughout 11 fe. He stated 1deas that were well known, that were common, that were hackneyed; but they are 1deas which the American people have not yet grown tired of reading and hearing. 35

"Everywhere," said Channing, "the document was well recelved, and gave new life to the cause of revolution." 36

Channing's ab1lity to write understandably of military matters becomes abundantly evident after his narrative passes the Declaration of Independence. It applies both to Ind1vidual battles and generalizations about the conflict:

The military annals of the Revolution are devold of the spectacular; they are lacking in useful lessons on the progress of the art of war. No remarkable soldier emerges from the conflict, for Washington was a moral force rather than a general; and of second-rate characters Nathanael Greene, alone, shines consplcuous. On the British slde, Howe, Cilnton, Burgoyne, and the rest were medlocre men. No great slege stimulates one's emotions almost to the breaking point. The brilliant feat of arms at Trenton, the hurrying flight of Greene across North Carolina, and the sudden stroke at Stony Polnt stand almost alone in exc1ting the 1magination. The task of the British was to conquer territory; that of the Americans to prevent their accomplishing this object. In war the enemy's army is the main objective. So 1 t was

$$
\begin{aligned}
& 35_{\text {Ib1d. . p. } 202 .} \\
& 36_{\text {Ib1d. , p. } 205 .}
\end{aligned}
$$


In this conflict; but the American army was not the force that actually stood in arms from year to year; 1t was the potential power of the farmers and planters of the continent. They formed an army, not actually in being, but capable of rapid moblilzation for brief periods. It was the certainty of oppos1tion by masses of poorly trained but determined men that kept the British confined to small districts on the seaboard and prevented their possessing territory which was essential to the reconquest of the continent. 37

The Americans could not prevent British capture of any town on the coast, sald Channing, nor could they eject the British from any important position. But they could prevent prolonged Inland excursions, and they could also keep the British from effectively occupying any large extent of territory. "The two armies were stalemated," he concluded, "unt1l time gave the welght of numbers and wealth to the opposers of Britain and her world-wide imperial aspirations." 38

The decisive event which time brought about to end the stalemate was the battle of Saratoga, fought in October, 1777 . To Channing this was a "great victory," a "glorious catastrophe"; 1t "brought Britain face to face with the trading nations of western Europe. From belng a looal conflict between two sections of the Brition empire, the war took on the rorm of a world-wide contest for domination." 39

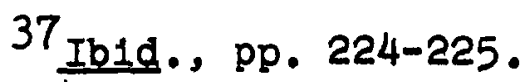

$38_{\text {Ib1d., p. } 210 .}$

$39_{\text {Ib1d., pp. } 241,273 .}$ 
Several already-noted Channing characteristics become prominent again in this volume. One of these is his naval interest. "PROF. CHANNING CLEVER SKIPPER," headilned the Boston Herald on June 19, 1913; it was one of the few times Channing came before the public eye in connection with anything other than his H1story. He was "reputed to be the most clever amateur skipper of small yachts on the south slde of Cape Cod."40 Samuel Eliot Morison stated that "Cisanning had a sure touch when dealing with matters of naval warfare and maritime commerce." 41 This was especially obvious in his treatment of the naval aspects of the Revolution. Though he had to admit that most of the naval action "had little effect on the war as a whole," he st1li thought John Paul Jones the "prince of seafighters." 42 And, even more slgnificantly, Channing was the first to point to the fact that the French naval victory of the Capes of the Chesapeake was the determining factor in the Yorktown campalgn; one of h1s aphorisms was, "The American Revolution was won in the dockyards of Brest and Toulon."43 Channing's enfoyment and ab1lity in working out historical "mysteries" is well 1llustrated by his extensive note

${ }^{40}$ Boston Herald, June 19, 1913, cllpping in the Edward Channing Quinquennial folder, Harvard Univers1ty Archives, Cambridge, Massachusetts.

4ISamuel El1ot Morlson, "Edward Channing: A Memo1r," Proceedings of the Massachusetts H1storical Soclety, LXIV (october, 1930-June, 1932), p. 258 .

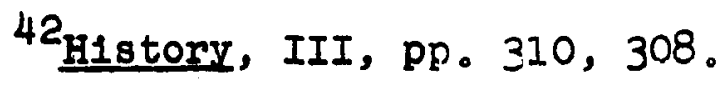
43 Morison, "Edward Channing," p. 258. 
note on Gates and Arnold at Saratoga。 44 Finally, his reliance on God, or "Providence," in explaining events at times, comes into play at several points in his treatment of the Revolution. 45 Channing gave scant attention to the role of the West In the revolutionary conflict, his grandson's avowal to the contrary notw1thstanding. Migration, settlement, and the activities of George Rogers Clark, all together, recelved little more than a page; Frederick Jackson Turner was relegated to two footnotes. 46

The role of other nations in colonial victory over Britain was by no means neglected by Channing. He felt that "the task to which King George and h1s minlsters addressed themselves in the summer of 1775 was wellnigh hopeless from the beginning," and he was certain that 1 t was "absolutely futile after France, Spain, and the other trading nations of Europe jo1ned the insurgents." Foreign individuals who came to Amer" 1ca to enlist in the cause of independence also recelved their due from Channing. "Some of them gave help of Inestimable value to the cause of Amer1ca," he sa1d. "Of these Lafayette was the exemplar." John Kalb and the Chevalier Du Porta1l were among the others "whose memorles should always be

44 H1story, III, pp。276-278.

45 Ib1d., pp. 226, 230, 266, 325 .

46 Ib1d. pp. 302-303, 32. Channing's grandson made a very weak case for his contention that neglect of the West was not a flaw of this volume. John Channing Fuller, "Edward Channing: Essays on The Man, The Teacher, and The Writer" (Unpublished senior honors thesis, W1illams College, 1943), pp. 118-119. 
gratefully revered," but "Of them all Steuben stands first in services performed." 4 ?

Channing's account of the peace negotiations was detalled and dispassionate. He did feel compelled to exonerate the action of the American diplomats in signing a separate treaty with Britain. ${ }^{48}$ But he seemed to be stralning too hard to be different when he questioned whether the treaty was really the great success for the United States wh1ch $1 t$ was ordinarily assumed to be. 49

Channing once again showed h1s ability to generalize meaningfully when he wrote thus of the years 1783 to 1789:

The years between the cessation of hostilities with Great Britain and the Inauguration of President Washington were memorable over all others in Amer1can annals for readjustments in politics, soclety, commerce and Industry. In politics, the governmental systems of the states were worked over and developed,

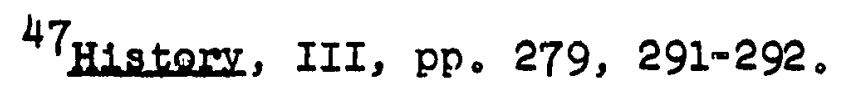

48 "The commissioners had broken their instructions;" he sa1d, "but was their action equivalent to pledging the United States to a breach of the treaty of $1778 \mathrm{w} 1 \mathrm{th}$ France, wh1ch obliged the contracting parties to flght on unt1l a general peace should be made? Technically, the UnIted States had observed this requirement. Negotiations for a general peace were being carrled on. All the treaties could not be concluded at one given moment, and the American commissioners had been careful to insert in the instrument that what had been agreed to were merely preliminary articles which should constitute a treaty eventualiy, 'but which treaty is not to be concluded unt1l terms of a peace shall be agreed upon between Great Britain and France, and H1s Britannic Majesty shall be ready to conclude such treaty accordingly.' Nor can 1 t be called a desertion of America's allies, for the preliminary articles between France and Great Britain were agreed to two weeks later, although they were not signed unt1l another month had passed away." (Ib1d., pp. 368-369.)

${ }^{49}$ Ib1d., pp. 369-370. 
and the weak Articles of Confederation were replaced by the Constitution. In soclety, distinct advances were made toward the realization of religious freedom; educational faclilties were improved and enlarged and were placed within the reach of many more people; and a beginning was made in the reorganization of the labor system. S1de by a1de with these changes, commerce and Industry were readjusted to sult the needs of a nation which was emerging from the colonial condition. 50

The amount of suffering and privation in the colonies In the war years was minimal, according to Channing, and that that did exist was due primarliy to transportation problems. 51 At the end of the conflict, then, prospects for the future seemed bright. "W1th free trade with all the world, with liberty to explo1t the1r great domain free from quitrents and parliamentary protection, with their political well-being absolutely in their own hands, what doubt could the American people have of their successful pursult of happiness!" But the opt1mism was misplaced. Commerce did not prosper, because the new United States found 1tself faced w1th the commerc1al barrlers of both England and former allies, and from this ensued a perlod of general hard times. Recovery had begun by 1786, but was not recognized by the delegates to the Const1tutional Convention at Ph1ladelphia in 1787, and the process was not completed unt11 1789.52

50 Ib1d., p. 388.

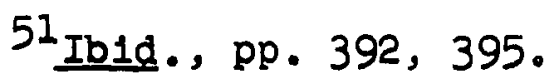

52 Ib1d., pp. 408-409, 481, 414. Michael Kraus, in The Writing of American H1story (Norman: University of Oklahoma Press, 1953), pp. 235-236, noted that Channing differed 
As a prelude to his discussion of the Articles of Confederation, Channing returned to the thesis stated in his preface, 1. $e_{e}$, that the most significant fact of American history had been the victory of the forces of union over those of part1cularism. He felt that the dwellers in each of the orlginal thirteen colonies had regarded themselves as forming a distinct administrative unit, that each was an absolutely soverelgn entity when the tie with Britain was broken, and that the constitutions which each state drew up continued the particularistic tendency. But Channing also contended that a sense of unlty had developed side by slde with these particularistic 1deas:

The political institutions of all the colonies were bottomed on those of England. The settlers had grown to power in conflict against imperial control. The colonists of the continents in their own eyes and in those of the dwellers in the other sections of the British empire formed a group by themselves.... The "Th1rteen" opposed the new Imperial policy in union. They assoclated themselves together to enforce their rights by a boycott as extensive as their independence, and had 1t acknowledged by Great Britain and the powers of the clvilized world. Friendly union was prior in point of time; in the eye of law and legal sanction the state organizations were first. The earliest legal obligation that any continentalist owed, after the severance of his alleglance to the British crown, was to his state. on the other hand, the mere fact that all the state governments were republican in form and that not one of them reproduced the monarchial institutions of the motheriand evinces more strongly than anything else the unity of political thought that prevalled among the people throughout continental America. 53

differed with historians who had painted a gloomy economic picture at the time of the Constitution.

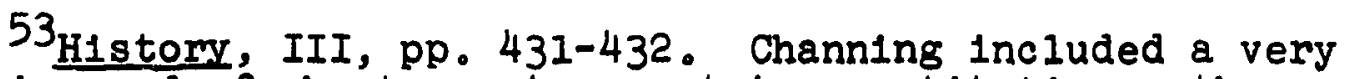
interesting end-of-chapter note on state constitutions, the 
Channing foreshadowed very early in this volume what his attitude toward the Articles of Confederation would be. He referred to its "Inadequacy," and noted that finally "the baleful effects of a weak central government became apparent and extorted the federal constitution from the necessities of the country."54 This was the general tone throughout; one chapter was ent1tled "Four Years of Confusion, 1783-1787." Channing even derided the committee which drew up the Articles; it consisted, he said, of "second-rate characters."55 The following words show the sweeping nature of his indictment:

The framing of the Articles of Confederation had taken much time and their ratification by the State legislatures had occupled more. They were obsolete when signed by members of Congress and antiquated when the Maryland delegates gave the consent of that state to their ratification. The ideal federative system led to the continued poverty of the general government, to fallure to adopt and enforce any effective commercial measures against host1le outsiders, to dangerous disagreements between several states, and to internal disorders in New England, Virginia, North Carolina, and elsewhere. Ali these led to reaction which found expression in the Constitution of 1787.55

major portion of whioh was a comparative table entitled "Conspectus of the Constitutions." (pp. 458-462) In the Harvard University Archives there is a "Catalog of Constitutional conventions in the Iibrary, made for Dr. Channing, and checked by the Law School in 1914." These things taken together indicate a rather extensive interest on Chaming's part in constititional history, even down to the state level.

$$
\begin{aligned}
& 54 \text { Ib1d., p. } 206 . \\
& 55_{\text {Ib1d., p. } 448 .} \\
& 56_{\text {Ib1d., p. } 463 .} .
\end{aligned}
$$


"Helplessness," concluded Channing, was the keynote of government in the Confederation per1od. 57

Most of Channing's comments on the Articles of Confederation fit rather well with John Fiske's 1dea that this was the "critical period" in American history. However, Merrill Jensen, the revisionist on the Confederation period, credited Channing with being ahead of his time in discerning the improving American commercial situation after 1783.58 Channing, like so many other historians, saw the movement which eventually led to the overthrow of the Articles of Confederation as the most significant thing about the entire Confederation period. He gave a brief account of the bulld-up to the Philadelphia Convention through the Alexandria for Mt. Vernon) and Annapolis conventions; he thought there was a "public consclousness" that the meeting at Ph1ladelphla was "on a very different footing" from these. "The consclousness of $1 \mathrm{~mm}$ inent public danger and the sudden willingness of the States and of the people to meet it was due to three principal causes," according to Channing. One of these was the great amount of internal disorder in different parts of the country; here Channing gave particular attention to Shays' Rebellion. The second was the threatened secession of the southwestern settlements. The third was the inability of the government to

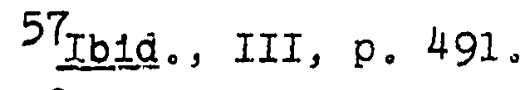

58 Merril1 Jensen, The New Nation: A H1story of the United States During the Confederation, 1781-1789 (New York: Vintage Books, 1950), p. 218. 
provide for the colonization of the area northwest of the Oh10 River. Th1s last problem, of course, was met by the passage of the Northwest Ordinance by the Confederation Congress at the very time the Constitutional Convention was in session. 59

"The Federal Convention and Its Work" was in many ways one of Channing's weakest chapters. Several reasons for this can be given. Once again, Channing seemed to feel that he did not have a great deal to say that was new, for thirty pages is not really much to devote to the Constitutional Convention, the Constitution 1tself, and the ratification thereof, in a work of this length. This is especially true in view of the fact that almost ten of the pages were taken up with prece dents for judiclal review. Indeed, those ten pages posed a problem in another way also, $1 e_{0} e_{0}$ organizationally; perhaps It could have been more appropriately included in volume IV in connection with Marbury vs. Madison. In splte of these problems, Channing did have some interesting comments on the Convention, the constituion, and ratification.

He noted that many delegates were late in arriving at Ph1ladelphia and that those present had already talked among themselves and arrived at general agreement on several 1mportant points. "Otherwise," he continued,

It is difficult to account for the rapidity with which the delegates decided to propose a plan that contemplated the destruction of the existing federal organ1zation and the establishment of a consolidated

${ }^{59}$ Ib1d., pp. 479-481. 
government that would be national in alm and supreme in operation. In the future, should this scheme be adopted, the existing state organizations would become secondary; the individual citizen would be directly responsible to the general government; and the acts of the new leglolative body would be supreme throughout the land. It is safe to say that had this outcome been ant1cipated, had the state leglslatures foreseen that the movement, in which they were asked to take part, would end in the loss of state sovereignty and the establishment of a government, federal only in name, not one state would have accepted the invitation of Congress and appointed delegates. The scheme formulated at Philadelphia was so wise in 1tself and so masterfully advocated by 1 ts friends, that, once before the voters, its ratification could not be prevented and the last stage in the American. Revolution was peacefuliy accomplished. The delegates came together intent on remedying the defects of the Articles of Confederation and did it by replacing the existing framework from foundation up by a form of government that was new to America and to the world. 00

Several specific provisions of the Constitution were praised by Channing. In a rare allegorical outburst, he wrote of the Supreme Court: "Always the court has gone on Its way performing 1ts gyroscoplc function of keepling the ship of state stead11y on her course." He thought the makers of the Const1tution achieved "phenomenal success" In the distribution of checks and balances. And he noted that the famous "necessary and propes" clause "has been expounded in the most liberal manner posisible, and has given the Constitution a fluldity that one would hardly expeot it to have from the mere perusal of 1 ts phraseology. "61

$$
\begin{aligned}
& 60_{\text {Ib1d., pp. } 494-495 .} \\
& 6 I_{\text {Ib1d., pp. } 508,509-510,516 .}
\end{aligned}
$$


Channing thought the method of ratification provided for in the Constitution "a most revolutionary scheme," because 1t proposed, as he sa1d, "that nine of the existing thirteen States agreeing to 1 t should secede from the existing federal union, establish a new government for themselves, and leave the other States to shift for themselves as weli as they might." In his brief acoount of the ratifioation struggle, Channing singled out "The Federal1st" papers as forming st11l "the best commentary on the princlples of government that underlie the American commonwealth." Ceneralizing about opinion on the Constitution, Channing noted that if a line had been drawn parallel to the seacoast, f1fty m1les inland, it would have pretty well separated the opponents of ratification from the propon-. ents thereor. "The favorers of the plan were the commerolal clesses," he said, "those who lived on settled 1noomes and the men of education; these for the most part resided to the eastward of this i1ne. "62

Channing expressed himself much more interestingly and forcerully on the Constitutional Convention in two letters to Max Farrand than he did in the areat Work. In 1909 he wrote explaining the present status of h1s views as follows:

When the delegates reached Ph1ladelphia, the mass of them, or most of them, had in mind remedy ing the defects of the Artioles of Confederation:- but, af ter they had settled down to work they undertook. to, in a positive manner, prepare a constitution which would go far beyond the Artioles of Confederation. That was the constitution of a federation;

62 Ib1d., pp. 516, 521, 522-523. 
they evolved a constitution for a consolidated government in which the federal princlple was distinctly subordinate. It 1s obvious, therefore, that they went far beyond the remedying of defects, although they did not by any means produce an $a$ prior1 thorough-go1ng, perfect constitution.63

The stronger statement came in a letter of 1913. Channing thanked Farrand for sending him a copy of his new book, The Framing of the Constituion, but continued by saying that "evidently you do not agree with me that 1t was a 'frame-up' on the part of the reactionarles to give the control of the government to the well born and r1ch。"64 Shades of Charles Beard:

Channing's independence of most "schools" of historlcal thought is well-evidenced by his treatment of some major topics in this third volume. He broke sharply with Bancroft's patriotic-nationalistic view of the Revolution as a struggle between 11 berty and tyranny. And, even though Channing's approach to colonial history up to the Revolution corresponded basically with his contemporarles of the Imperial School, this was no longer true when he reached the causes of that conflict. Whereas Beer, for example, malntalned that political and constitutional 1ssues brought on the Revolution, Channing contended that "commerclalism," 1. es, economic factors, was at

\section{Channing to Max Farrand, June 2, 1909, Channing} Correspondence, 1897-1929, Harvard UnIvers1ty Arch1ves, Cambriage, Massachusetts. Th1s awesome name actually describes one small folder of seventeen letters, slxteen to Farrand and one to Marcus $w$. Jernegan.

64 Ib1d., Apr11 9, 1913. 
the heart of 1t al1. Thus both here, and on the Constitution, Channing came close to the approach of the Progressive historians of the early twentieth century such as Beard.

Even for a historian who had as many problems in organization of material as Edward Chanring did, placing a chapter on the Ordinance of 1787 after the one which carried the story through ratification of the Constitution seems a bit strange. St1ll, he managed to justify it somewhat. The tIme had come by 1790, he noted, "to formulate a pollcy of colonization fitted for a republican state." An "1deal system" had been "shadowed forth" in the Ordinance of 1787. Channing recognized Jefferson's 1784 measure as having la1d the foundation for the one in 1787. He also discussed briefly the land ordinance of 1785 , and summarized the significance of all three rather well when he wrote: "As Jefferson's Ordinance of 1784 was the basis on which the American plan of colonization was founded, so th1s Ordinance of $1785 \mathrm{ls}$ the forerunner of the land system of the next century." 65

The content of Channing's last chapter, "At the End of the Era," reminds the reader how little of the nontraditional material, $1, e_{e}$, social and cultural, there has been in the volume up to that point. Channing recognized th1s. "It w111 be convenient in this place," he sald, "to

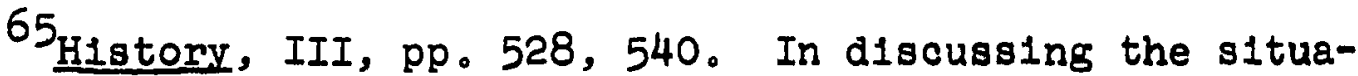
tion as of 1790 Channing made use of a colored fold-out map (between pp. 528 and 529) showing the extent of settlement at that time. 
pass in review some of the soclological topics that have already been noticed in the earlier perlods," and then contInued, with what can only be taken as one of his overgeneral1zations, "for American history deals above all with the interaction of human aspirations and economic forces."66 If he had really belleved in that last idea, it seems that his History would have been quite different in nature. He followed the statement with a brief discussion of several of those "soclological topics," Including Immigration, slavery, religion, education, and social reforms.

Channing concluded the volume with praise for the 1761-1789 generation:

In the thirty years that have just been passed in review, the American people had seceded from the mother country, established republican forms of government within their thirteen States, and had gone far in the readjustment of economic life to their new conditions. They had devised a colonial system that harmonized with their political principles and was to succeed in the coming century beyond that of any other colonizing country of the earth. They had adopted a form of federal government that was new to the world, republican in essence and Imperlal in power. These were large achlevements for a single generation. - No wonder that they looked forward with hope to the coming years. Announcing the ratification of the Const1tution by New Hampshire and Virginia, the "Pennsylvanla Packet" on JuIy 14, 1788 , thus advert1sed the establishment of the new Union:--

$$
\text { "SHIP NEWS-EXTRA }
$$

"Arrived safe in port, the ship 'Federal Const1tution,' Perpetual Union, commander. In her came passengers Flourishing Commerce, Publ1c Falth: Confidence, Justice.

66

Ib1d., p. 552 .

67 Ib1d., p. 573 . 
The American Revolution was one of Edward Channing's finest volumes, certalnly far superior to the second volume of h1s H1story. Paul H. Buck st111 thought in 1967 that 1t was "as good as we have" on the Revolution. Channing's grandson considered 1t one of the two best volumes of the series, and thought it had "no striking drawbacks." And Channing himself was proud of 1t. "I hope you like the third volume," he wrote to J. Franklin Jameson shortly after 1ts publication, "for there is a lot of new matter in 1t. Of course, my interpretation of this new stuff may or may not be pleasing to you or to any one else," he continued, "but I think the profession ought to be grateful for the time and money that I have spent in algging." 68

\section{Jameson responded to Channing's comments that "your} third volume seems to have been recelved with unlversal favor. For my part, I like it very much."69 The favorable reception was, Indeed, almost unlversal. Revlews wh1ch, in general, pra1sed the work appeared in the Engl1sh H1storical Rev1ew, the Annals of the American Academy of Polltical and Soc1al Sclence, the American Library Association Bookl1st, the Amer1can Review of Reviews, the Outlook, ${ }^{70}$ the Nat1on, the D121, and

68 Interview with Paul H. Buck, June 9, 1967, Cambridge, Massachusetts; Fuller, "Edward Channing," pp. 119, 116; and Channing to Jameson, November 23, 1912, Jameson Collection. Collection.

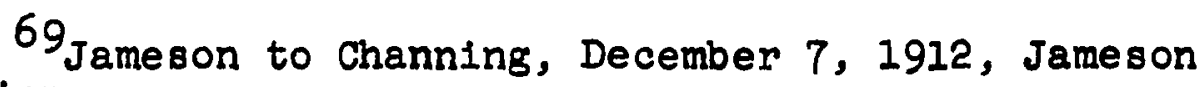

70H. E. Egerton, Engl1sh H1storical Rev1ew, XXVIII (January, 1913), pp. 170-173; Emory h. Johnson, Annals of the 
the American Historical Review. Of these, the last three deserve special mention.

The anonymous revlewer for the Nation used Channing's volume as a take-off point for an entlrely different interpretation of the Revolution. The desire of the colonists for home rule, he said, Channing seemed to understand very well. But another very 1mportant aspect of the same problem he seemed not to understand at all, $1 e_{e}$, class conflict within the colonies themselves. Almost half the review is an elaboration of this class conflict interpretation of American history. The reviewer did praise Channing for his "scholar's conscience" in the use of sources, his "direct and lucld" style, and his freedom from "Inaccuracies and exaggerations of the sort to which American writers were once prone."71

St. George Leakin Sloussat, in the Dial, noted Channing's thesis that commercial factors were at the heart of the Anglo-Amerlcan divergence and concluded that it was Channing's emphasis on this, plus "the freshness of his treatment," that gave the volume 1ts distinction. He praised Channing for not

American Academy of Pol1tical and Soc1al Sclence, XIVIII (July, 1913), pp. 272-273; Amer1can Review of Rev1ens, XLVII (March, 1913), po 375; and out1ook, CII (November 16, 1912), p. 596 .

$7^{1}$ Nation, XCV (November 21, 1912), pp. 482-483。 Paradoxicaliy, the reviewer continued in this vein for a while, noting Channing's "freedom from ant1-British prejudice," then ended by critlclzing him for teling again "the story with which we are familiar," 1 e, e, "that $1 t$ was right for the colonists to seek advantage and profit in trade, but wrong for Englishmen to do so," and that the colonists "were united in meeting an unjust attempt at explo1tation by legitimate resistance." (p.482) 
taking up too much space with military history, and for exerclsing a "Judiclous restraint" in dealing with this toplc. Sloussat thought Channing steered clear of sectlonal blas between North and South, but Just1flably questioned whether the West had recleved its due. He also made an entirely valid criticism when he stated that after the Revolution, "one begins to feel a sense of compression and omission which accompanies one to the end of the book." The review ended by ha1ling the volume as "another instaliment of a notable contribution to American history."72

The most useful revlew of all those which The American Revolution recelved was that by $\mathrm{C}$. $\mathrm{H}$. Van Tyne in the American Historical Review. He pra1sed Channing for h1s "mastery of the period," his "clear, direct style, unadorned except by the simple ornament of truth," his restraint, his "historical technic" ("well-nigh faultless"), his generosity in recognizing the work of others, and his wide use of sources. "After some twelve years' study of the per1od," sa1d Van Tyne, "the revlewer found the volume abounding in facts that he did not know, and sown w1th shrewd and canny interpretations which are new and yet convincing." 73

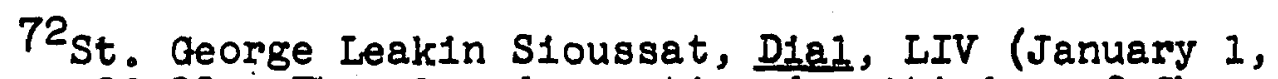
1913), pp. 20-22. The already-mentioned crit101sm of channing for lgnoring the West was an 1ssue to practically everyone who commented on the volume. One historian accused Channing of being "oblivious to any divergence of sentiment between the eastern seaboard and the backcountry and unaware that a West existed as an important influence on the Revolution." (Ralph Ray Fahrney, "Edward Channing," in Hutchinson, Jernesan Essays, p. 299.)

73C. H. Van Tyne, Amer1oan H1storical Review, XVIII (Apri1, 1913), p.60。 
Al1 th1s was in the opening paragraph; Van Tyne then turned to criticism. Channing's account, he complained, "rarely leaves the Atlantic coast," so that forelgn matters of importance and the contribution of the West to the Revolution receive only "the cold respect of a passing glance" and "the most meagre treatment," respect1vely. Van Tyne also declared "a radical difference of opinion" w1th Channing as to the fundamental causes of the Revolution. Channing, he said, showed "an astonlshing blindness to soclal forces, notably those of sectarian and ecclesiastical character." He also considered Channing guilty of "placing the incidental cart before the causal horse" in saying that the differences of political thought between the English and the colonists resulted from the economic differences, $1, e_{2}$, the dispute over trade and taxat1on. 74

Van Tyne admltted, however, that there was room for difference of oplnion on all these matters. He then proceeded to point out some "actual errors" on Channing's part; but these were relatively insigniflcant. Finally, Van Tyne became a bit nasty. "The reviewer hardly needs to say that he views w1th compassion Professor Channing's non-commltal att1tude on the subject of state soverelgnty in the Revolution," he wrote. "Had he read a certain article on that subject-- or which he seems unaware--1n volume XII of the American H1storlcal Review,

74 Ib1d., pp. 603-605. 
he could not have been in such Egyptian darkness."75 Channing did not appreciate that comment. When he wrote to Farrand thanking him for The Framing of the Constituion, he concluded the letter in this fashion:

I would that the book had come earlier. My only consolation in 1 ts late appearance is that thereby I was prevented from omitting it from a foot-note and thereby incurring your enmity as I seem to have gained Van Tyne's by not embalming his article on state Sovereignty in a note. But I should not have forgotten it and if $I$ had you would not have la1d it up against Very truly your'so-
Edward Channing 76

In conclusion, it is well to remember, after all this, that Van Tyne did end on the note of praise with which he had begun: "In spite of the faultsmif, indeed, they are faults, and the reviewer not mistaken-the work is a permanent monument to American scholarship, a virile, trutinful, and inspir ing history, worthy of the great theme ${ }^{177}$

75Ib1d., p. 605. The article Van Tyne referred to was his own "Savereignty in the American Revolution: An Historical Study," American H1storical Rev1ew, XII (Apri1, 1907), pp。529545.

76 Channing to Farrand, Apr11 9, 1913, Channing Correspondence.

77 Van Tyne review, p. 605 . 
Vol. IV seems to have struck a new note, although why I do not say. It seems to me to be of a plece with the rest. If any body buys 1t, I don't care why they suddenly seem to recognize the historical and ilterary merits of

Very truly yours
Edward Channing. 1

Once Channing was ready to move into the national period in his H1story, he was anxious to concentrate on it in his teaching also. The problem, however, was that the course then being offered covering that era was Albert BushnelI Hart's famous H1story 13 , and he was less than anxious to give it up. Indeed, it was only through what, "In retrospect, seems a rather sorry academic intrigue" that the course was "taken away" from him. Fortunately, the leading flgure in the Intrigue seems not to have been Channing, but another member of the history department, Archibald Cary Coolidge, who "disliked Hart and wanted him out of the history department altogether." Th1s was accomplished in 1914, thanks partially to the intrigue, but partialiy also to the fact that Hart's interests had been leaning more and more to government anyway-he had become chairman of that department upon 1ts creation in 1910. Hart, in giving up the course, made the "rather

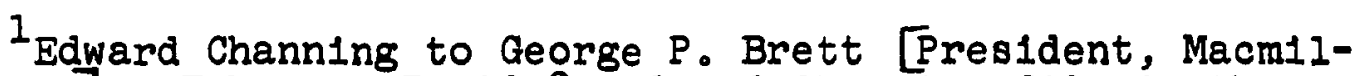
lan Company], February 7, 1918, Edward Channing flle in the Macmilian Authors Collection, New York Public Library. 
touching condition" that the number he had used for it for thirty years not be used by anyone else. Channing's course wh1ch replaced it was thus known as H1story $32{ }^{2}$

From this point on, Channing's teaching was more and more restricted in amount and 11 mited to what he was then writing. Indeed, it must have been quite important to Channing to have his entire thought process move along together through American history. A 11 brary employee once went to Channing with a minor question, to which he certalnly knew the answer. But his reply was, "That is in volume two; I am in volume four. When I complete one of those things, I forget about it and move on to the next one." 3 Doubtless too much could be made of such an anecdote, but the point must have some validity--Channing did not answer the question.

Channing was relleved of his teaching duties for the first semester of the academic year 1912-1913. He used most of the time for a trip to Europe to rest up after completing his third volume. On his return he proudly wrote to Qeorge P. Brett: "Wh1le I was away the Corporation of Harvard University ralsed my salary and appointed me to the old h1storlc McLean

2This account is based on Samuel El1ot Morison, "A Memoir and Estimate of Albert Bushnell Hart," Proceedings of the Massachusetts Historical Soc1ety, CXXVII (JanuaryDecember, 1965), pp. 43-44。

3 Interv1ew with Robert H. Haynes, August 24, 1966, Cambridge, Massachusetts. 
Professorship of History once held by Jared Sparks. So our home coming has been pleasant."4

Thus encouraged, Channing wasted no more time in golng on with the Great Work. "I have begun volume IV and shall go ahead with it as rapidiy as possible," he wrote again to Brett on September 24, 1913. But Channing had problems in working on this fourth volume. He hinted at them in this same letter when he mentioned that he had to teach full-time in the 19131914 academic year, both because of his financial condition and the effect taking off another semester would have on his retirement benef1ts. "Being a professor, as you see, has its drawbacks," he lamented. But he could still see the bright side. He expressed appreclation that the Harvard administration had been "very kind" in allowing him to plan his teaching to go along with his writing, then went on:

This gives me a chance to "try $1 t$ " on successive

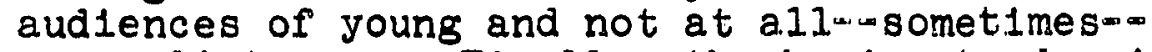
eager listeners. Finally, the having to do with bodies of students as a lecturer and with ind1vidual students, as a director of research, keeps me from getting stale and broadens my outlook as only intercourse with numbers of men from all over the country can. For these reasons I am rather inclined to think that my teaching work as it is arranged rather alds than retards my 11terary pursuits.5

${ }^{4}$ Channing to Brett, February 13, 1913, Macmillan Collection. A copy of the certificate attesting Channing's election to the McLean professorship is in the Channing folder of the A. Lawrence Lowell Papers, Harvard University Archives, Cambridge, Massachusetts. Collection.

${ }^{5}$ Channing to Brett, September 24, 1913, Macm111an 
Desp1te th1s, however, by January, 1915, Channing was thoroughly dejected. He wrote to President A. Lawrence Lowell asking for a half-year off in the next academic year, and in the course of the letter expressed concern about retirement benefits, the lease on his house, the courses he was to teach the next year, and his progress on the History. He continued:

I am afraid that I appear rather insistent, but I am greatiy puzzled as to what to do. My volume four is well along, but the amount of material remalning to be studied is st1ll great. If I am to go on with th1s work, I have got to make greater speed that [s1c] I have been making lately...I am also consclous that lecturing to my large class leaves me much more inert than was the case ten or five years ago. It seems to be the case of elther giving up the book, or the teaching, or distributing my time somewhat differently。

Channing overcame his despondency, however, doubtless alded by the fact that he got off the semester as he requested. "I am pegging away at volume IV and hope to see it in prosf a year from now," he was Informing Brett on August 29, 1915. "I have a half-year off--beginning with February 1916--which w1ll give me a chance to finish 1t." He even found time to Indulge In some 11ght reading. "I w1sh that I could wrlte as well as Owen W1ster," he told Brett in the same letter. "I read Galamity through last evening and thank you very much for sendIng it to me." A few weeks earlier he had thanked Brett for some books and expressed his literary inclinations thus: "For me give me blood and thunder like the 'Sunday Magazine' or

\footnotetext{
${ }^{6}$ Channing to Lowe11, January 2, 1915, Lowell Papers.
} 
real w1ckedness as Guy de Maupassant--or true tales--Hakluyt, Purchas, Capt. Cook."7

In splte of all his problems, Channing moved along rather well on Federalists and Republicans. He wrote Brett In June, 1916, that 1t was "approaching completion," and in December that 1 was done. 8 It was publ1shed in Apr11, 1917, which was also the month of American entry into the first World War. That conflict affected Channing's work in several ways. "This war is certalnly disrupting things," he wrote Brett in September, "but, so far, my understudy has not been drafted--he is too thin--so the prospect is that my plans of study and teaching w1ll not be interfered w1th. We are, however, drifting from week to week." 9 The disruption caused by the war did not materlally affect Channing's progress on the Great Work, for less time lapsed between volumes IV and V than had between III and IV. St111, he did "generously" take up some of the h1story department's "abandoned courses while h1s younger colleagues were in the service." 10

The war also provided the occasion for one of the few times that Channing ran afoul of the professional patriots.

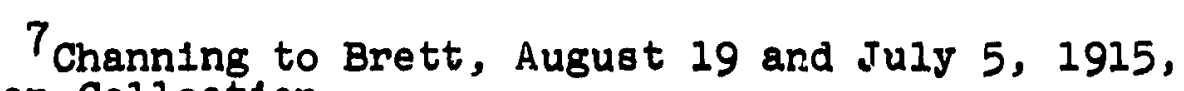
Macmillan Collection.

8 Ib1d., June 28 and December 4, 1916.

Ifld., September 20, 1917.

${ }^{10}$ Samuel Eliot Morison, "Edward Channing: A Memo1r," Proceedings or the Massachusetts H18tor1eal Soclety, IXIV (October, 1930-June, 1932), p. 283. 
In the Boston Advertiser for January 27, 1916, a strange article appeared under the headline, "Unpatriotic Americans of Today, L1ke Yankee Heroes of Old, Scored by Harvard Man." It announced that a "new argument for preparedness" had been advanced at Harvard.

Prof. Edward Channing, McLean professor of history, is the author, and his statement is that Americans are the most unpatriotic people on the face of the globe. "For this reason," says Prof". Channing, "we ought to train our young men to flght because ignorance added to a natural disinclination to fight would place us in a sorry plight should we be attacked.1.1

That was all he sald about the war. But he must have been trying to stir up controversy, for he then launched into a tirade on the revolutionary period. He denounced the British in much stronger terms thas he had in the History: "Fortunate It was for us that the English government was then in the hands of the stupidest officials that England has ever had (and that is certainly saying something)。" That, however, probably offended only a few. His comments on such heroes as Benjamin Frank11n, Patrick Henry, and George Washington must have offended many. Channing, said the paper, presented Washington as a "p1tiful blunderer."12 Here is the major portion of his comments on that person of whom he had written in his second

${ }^{11}$ Boston Advert1ser, January 27, 1916。 (In Channing's folder of the "Quinquennial File" of Clippings on Harvard Men, in the Harvard University Archlves。) The paper did not make clear whether Channing's comments came in a speech, an interview, or some other form. 
volume, "Of all men in history, not one so answers our expectations as Washington": 13

"George Washington had no 1nitiative of his own, and often walted so long for the advice of big men and Congress that his strategic opportunities were lost. If 1 t had not been for Coune [s10] de Gras and his fleet Washington could never have stepped in on Cornwal11s at Yorktown.

"The 'Father of our Country' did not think of the great 1dea even at that. He didn't have b1g 1deas-as is eas1ly proven by the management of his personal business.

"The face and flgure of Washington is familiar to us all. But the traditional George is not like the real one. The reason he has that strong, square Jaw is that toward the end of his $11 f^{\circ} e$ he had a pair of old-faghloned false teeth whlch were worked by a spring."14

Channing did manage to relate these comments somewhat to the problem of preparedness in the era of World War I. "It was only by accldent that we won the Revolutionary war," the paper quoted him as concluding, "and we could not hope for this again." 15

Channing must have made other comments similar in nature after Amer1can entry 1nto the war. In Apr11, 1919, he wrote a self-explanatory letter to Max Farrand whlch is one of his most humorous extant and bears extens1ve quotation ar You're another! Or, rather, you are the only one. It appears from the "Washington Star" of"

13Edward Channing, A History of the United States. Volume II: A Century of Colonial H1story, 1660-1760 (New York: The Macmilian Company, 1908), p. 559.

14 Boston Advert1ser, January $27,1916$. 15 Ibid. 
Apr11 15, 1919, that Mrs. I11y Ell1ott and M1ss A. L. Thompson of Maryland as a committee have denounced us to the D. A. R. as declaring that $G$. W. was a self1sh, tyrannical, and unjust man; that.P. Henry was dishonest; that the Boston 81219 preferred the Britishers to the Continentals; that the American soldiers were not defeated because they ran so fast, the British couldn't catch them; and that the only purpose served by the Decl. of Ind. was to furntsh a national hol1day. Furthermore, they call upon every D. A. R. and every woman in the U. S. "to make the matter her own personal affair and to use every infiuence she possesses to compell the governing bodles of Harvard and Yale properly to punish the two professors." As I have never belleved any of the above things and therefore oould never have stated them, you are undoubtedly the person who is in for 1 and I hope you w11l get your deserts:

Serlously, I wonder whether we should regard this as good advertising or should invoke the law of 11 bel to shut up the aforesaid El1ott [110] and Thompson. Personally, I should very muoh like flifty thousand to put 1nto the V1otory Loan; but whether the aforesa1d ladies are worth $\$ 100,000$, or whether we could collect it from the $D_{0} A$. R. 18 not olear to me. Per contra! I have just been reading a review of your book in "The New Republ1c" by the redoubtable Roland $Q$. [Usher, a former Channing ansistant] He seem to have been Inc1ted by the sdvertimement of your book, to plaoing me on a pedestal and to have suggested that I am the real ordginal originator of the modern American history and that you are-cwe11, I don't know what. At any rate, the latter part of the not 100 is so laudatory of $M$. B. ind the whole 10 laudatory of both of $u s$, that I am rather Inolined to think that we are the only living historians in Amerion worth mentioning, and the only thing for us to oonsider $1 \mathrm{~s}$ how muoh of the one hundred thounand we get fyou the D. A. R. we ought to hand over to Roland. 16

Colno1dentaliy, war was a contral top1o in Channing's fourth volume, alsos the Tripolitan War, the Napoleonto Wars, and the war of 1812 altogether oooupy approximately hals the

${ }^{16}$ Channing to Farrand, Apr11 22, 1919, Channing Correspondenoe, 1897-1929, Harvard UnIvers1ty Arohives, Cambridge, Massechusetts. 
space. But these were so closely tied in with other developments of the period, foreign and domestic, that it w11l be best to cover the 1789-1815 period in order as Channing did. The first chapter of Federalists and Republicans is the only one devoted entirely to non-political matters. As usual when Channing is dealing w1th th1s k1nd of materlal, his comments are interesting but somehow seem strangely unrelated to the general story. One problem is the diversity, as ev1denced by this 11st of page headings from the chapter: population, transportation, postal facilities, compensations, simpliolty of 11ving, prices, amusements, drinking hablts, treatment of disease, the yellow fever, patent medicines, and lotterles. All that in twenty-seven pages!

Channing gave considerable emphasis to transportation In this first chapter, thus foreshadoinging the major thesis he was to put forth on that subject in his next volume. "Of all the things that stood in the way of a realization of the dreams of those who had made the Constitution none was more formidable than the difficulties of transportation," he wrote. The application of steam to transportation in this period "changed the whole face of clvilization by making practicable what had before been 1mpossible." And these new conditions of living led to changed manners of thinking-" to the liberalization of the mind, to solentific evolution, to the breaking down of religlous barriers, to a radical alteration in the ethioal outlook, and to the creation of a new literature." Channing 
even related this topic to his central theme of union versus particularism. "Under these dfficulties of transportation, the task of administering affairs of peace and war from any one c1ty was certain to be great," he noted. And he wondered, "In view of the divergent interests of the several parts of the country, and of all the soc1al and political prejudices that attended on these divergences, was it golng to be possible to adminlster a constantiy growing oonsolldated federal government for any length of time?" Innovations in transportation, he implied in the next question, helped make it possible: "Had not the steamboat, the rallroad, and the telegraph come when they did would the UnIon have long oontinued?"17

Th1s first ohapter was also one of the very few places In the ent1re Hatory where Channing showed evidence of having done researoh in newspapers. He footnoted them speo1f 10al1y for some of hls comments on amusements, but he was very caut1ous about relying on them. Th1s was in ine with h1s general attltude toward newpopers as sourcen, for he reportediy nald, "The ondy thing you oan belleve in newapapers are the advert1sements. "18 In the end-or-chapter b1bllographloal notes, he commented on the work of John Bach Mollanter, who relled vo extensively on newspapers for h1s soc1al h1story: "MoMaster

17 Edward Channing, A History of the United Stateg. Volume IV: Federal1 btit and Repub110ang 1789-1815 (New York: The Naomilian Company, 1917), pp. 2, 1-2, 8.

18 Interview w1th Paul H. Buck, June 9, 1967, Cambridge, Massachusetts. 
used the newspapers with great effect, but, sometimes, w1thout the exercise of the critical care which this class of materlal peculiarly demands." 19

Channing made some other interesting bibliographical comments here also. Continuing w1th McMaster, he noted that the author attempted to go "far beyond the merely political" and sought "to bring to view the reasons for political action." Channing thought McMaster's work "unsurpassed" as "a storehouse and Index to material," but objected to "a certain metalI1c quality" about the style and "a lack of variation" which made the book "difficult reading in any quantitative manner." Other authors of mult1-volume histories who recelved mention were Rlchard H1ldreth, James Schouler, and Hermann von Holst. H1ldreth's history, sa1d Channing, "remains to th1s day the most satiafactory account of the administrations of Washington and John Adams, although written three-quarters of a century ago." It "has no pretensions to 11terary merit, is a mere annal, and is prejudiced," he continued, "but it gives the facts accurately and in usable form." Schouler was dismissed more brlefly. H1s "sympathies are with Jefferson rather than with the Federal1sts," Channing wrote, "but h1s style 1s as dry as that of Hildreth." Von Holst was dealt w1th briefest of all; Indeed, his work was mentioned only in a footnote. It "enfoyed great vogue when 1 appeared," Channing recorded, 
"but owing to his doctrinalre treatment of our history has since lost favor." John Spencer Bassett's Federal1st System In the American Nation series was singled out by Channing as an "excellent" smaller work. 20

One of the most interesting and unique side 11ghts of Channing's diversifled first chapter was his comments on the drinking habits of the day. Emphasizing the paucity of amusements, Channing concluded that "the easlest way to forget one's self was to take to alcohollc stimulants." Thus, these "were consumed in almost fabulous quant1ties." Among wellknown public figures who indulged rather extensively were Thomas Jefferson, James Madison, and Rufus K1ng. Channing speculated:

It is one of the most curlous pursuits of the historian to seek to relate cause and effect. There 1s little doubt of the preeminence of Jefferson and Madison in the office of Secretary of State, and we have had few better representatives at Iondon than Rufus K1ng. "Whether alcohol quiokened or dimmed their inteliects would probably best be left for dec1sion to others. What effect it produced on the1s bodily health 18 also an interesting Inquiry and one upon which conolusion would be quite as difficult. King died at the age of seventy-two, Jefferson at e1ghty-three, and Madison at e1ghtyfive, after years of service unsurpassed each in h1s way.

One reviewer thought these comments might "bring the author some embarassment." "If the American Liquor Dealer's Association does not jump at this proof of the good effects of

$$
\begin{aligned}
& 20_{\text {Ib1d. }} . \\
& 21_{\text {Ib1d. }} \text { pp. 17-18. }
\end{aligned}
$$


partaking of the 'good things' of $11 f e, "$ wrote W1lliam E. Dodd in the D1al, "1t w1ll be because its press agents do not look to the pages of grave and sober historlans for support of their cause." 22

Th1s little diversion by Channing provides the opportunlty to indulge in a simliar one here, 1,es, a brief note on Channing's own drinking hab1ts. The few 1tems on that subject which appear in his correspondence are not slgniflcant enough to lead to any concluslons, but they are interesting and sometimes humorous. He wrote to J. Franklin Jameson once enclosing a wine advertisement which, he sa1d, dropped out of a copy of the Engligh Historical Review. "It occurred to me," he continued, "that similar leaflets, Inserted in the American H1storlcal Rev1ew, of W11son's Rye and Schl1tz's Beer might put that publication on a firm financlal footing and save the members of the Assoclation from the payment of any further dues."23 Most of Channing's comments on his own inclinations to Imbibe are found in his correspondence with Brett. "By the. way," he wrote after a trip by sea to Richmond, Virginia, for research, "my steamer had some very good Sparkling Moselle of which I annexed a pint every night and thought that it was a p1ty that some of good frlends were not with me to make it a quart." The last year of his 11 fe he was st1ll 1ndulging,

22 W1111am E. Dodd, D12], IXIII (Ju1y 19, 1917), p. 62. ${ }^{23}$ Channing to Jameson, May 22, 1911, John Franklin Jameson Papers, Manuscript Divis1on, Library of Congress, Washington, D. C. 
for he wrote, en route to England: "In the smoking room at night, before going to bed, I take a glass of Chartreuse to your very good health and prosperity." 24 Finally, a meeting of the Executive Counc1l of the American Historicol Association in 1920, when Channing was president, must have turned into a drinking bout of sorts, for John Spencer Bassett, the secretary, wrote to Channing a few days later: "I hope you are well and that you have recovered from the contaminating effects of Munro's spirits on Thursday n1ght."25

Though he separated it 1nto two volumes, Channing must have seen the perlod 1789-1848 as one in many ways. Besides the emphasis on transportation, there were several other things which led him to this view. He called his fifth volume, on the period 1815-1848, The Per1od of Transition, but he saw the 1789-1815 period as such an age also.

The twenty-five years covered in the present volume were distinctiy a period of transition from the old order of things to the new, from the modes of thought and action of the seventeenth and eighteenth centuries to those of our own times. At the moment, the future seemed full of doubt. There were most rovel and urgent problems of administration and of finance to be settled at home; and the relations of the United States with the outer world were never more precarfous than they were in this quarter of a century.

24 Channing to Brett, January 7, 1922, and May 23, 1930, Macmilian Collection.

25 Bassett to Channing, December 31, 1920, American Historical Association Collection, Secretary File, Manuscript Division, Library of Congress, Washington, D. C. The Munro was William Bennett Munro, the historian.

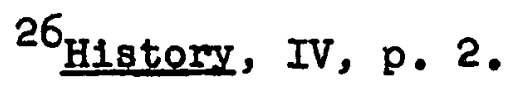


For some reason, there was much less openly evaluative and/or Interpretive material in Pederalists and Republ1cans than in any of the first three volumes of the Great Work. Since the coverage here necessar1ly emphasizes that type of material, this volume can be dealt with less extensively. In his treatment of George Washington here, Channing did not indulge in the unbridled praise of his earlier volumes. He emphasized the difference between the "traditional" and the "real" Washington. The latter, he sa1d, was very difflcult to discover--"no more elusive personality exists in history." 27 The former was largely the creation, according to Channing, of "two scottish men of genlous," allbert Stuart and Mason $L$. "Parsons" Weems. Channing thought it was "extremely doubtful" as to how closely the Stuart portrait resembled "the actual Washington." And he stated dec1sively that the Washington "or. the cherry tree and hatchet" was a product of "the imagination and pen" of Weems, and was "a most striking example of the pseudo-historical art which some persons oonfuse with history." The first serious study of Washington was that by Chlef Just1ce John Marshall, Channing noted, but he consldered the best treatment published as of 1917 to be Paul Lelcester Ford's True George Washington. 28

"Probably never in modern history has a successful revolutionary leader been so bereft of any tanglble means of

$$
\begin{aligned}
& 27_{\text {Ib1d.., p. } 34 .} \\
& 28_{\text {Ib1d.., pp. } 57-58 .}
\end{aligned}
$$


compulsion," sald Channing, emphasizing the "chaotic cond1tion of affalrs" at the time of washington's inaugural. 29 Most aspects of "Organization of the Government" by the WashIngton administration Channing treated favorably. The early evolution of the cabinet, however, he described and evaluated in a very critical fashion: "Thus was established a counc1l that was not elected, that was appointed by 1ts presiding officer--w1th the advice and consent of the Senate--and was removable by h1m,--actualiy an institutional monstrosity." And, though he would say more on the subject later, Channing was careful even at this point to place blame where he felt 1t was due for one institution in American politics. The spoils system, he wrote, "Instead of being an invention of Jacksonlan Democrats or Jeffersonian Republicans, was an Inher1tance from the Federal1st Presidents and by them had been built up on colonial and English precedents." Channing also very objectively included some of his ancestors, the Ellerys of Rhode Island, among those men of "lesser clay," the professlonal office-seekers, who, through the spo1is system, "fed at the public crib" for generation after generation. 30

In a chapter on "Credit and Commerce," the central f1gure was necessar1iy Alexander Hamilton. Channing had earlier called him "one of the most remarkable men to whom the

$$
\begin{aligned}
& { }^{29_{\text {Ib1d., }}} \text { pp. } 36-37 . \\
& { }^{30_{\text {Ib1d. }},} \text { pp. } 47,56,50 .
\end{aligned}
$$


United States is indebted for 1ts place among the nations."31 Here the praise was st111 present, but modified. "It 1s Impossible to overstate the debt of the American people to this far-seeing fearless statesman," wrote Channing, "but it 1s well also to remember that he made somc of the cruelest political blunders in our history." St111, the over-all tone was favorable:

Apart from adminlstration, Hamliton had extraordinary intultion in forecasting with a statesman's imagination the material development of Amerioa. He organized the assets of the nation, caling to his ald all the elements that were in the future to exploit the resources of the country. He was the organizer of exploitation, the originator of monopoly; but he did hls work at the precise moment that exploitation needed to be organized and human fingenulty required exc1tation by hope of monopoly. 32

For Hamilton's flrst report on the public credit, in which he put forth the famous funding and assumption proposa1s, Channing had nothing but pra1se. The whlskey Insurrection in western Pennsylvania, stirred up by Hamilton's exc1se tax, Channing saw as Hamilton himself probably did. It was "no unmixed ev11," he wrote, "because 1t enabled the federal government to show 1 ts power and to prove that 1 t was no mere rope of sand that could be eas1ly dissolved."33 And he concluded the chapter in this fashion:

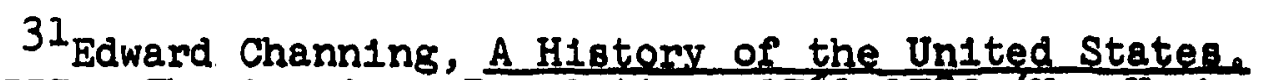
Volume III: The Amerlcan Revolution 1761-1789 (New York: The Macmilian Company, 1912), pp. 463-464.

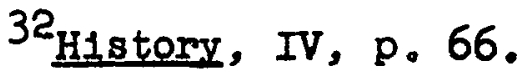

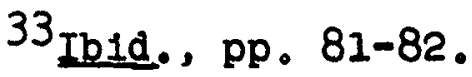




\section{6}

Never in the course of history has there been so immediate and permanent a financial foundation lald for any country's prosperity as that which was built by Hamilton, the men of the First Congress, and President washington. It is true that they had in their hands an opportunity greater than was ever vouchsafed to any other beginners of a state. There were no national financial institutions to hamper them; there were no laws, regulations, or traditions to hinder them from pursuing the path of w1sdom. The slate was perfectly clean. They might establish the credit of the government of the United States on a firm basis; or they might give it an insufficient underpining that would collapse under the welght of the super-structure of later years. They acted with a sagac1ty that the world has seldom seen. The fabric that they wrought has been changed and mended from time to time to meet the needs of succeeding generations, but the framework is even now essentialiy as they left 1 t. 34

In a chapter on the rampant speculation in the period 1789-1800, the activ1t1es of Robert Morris stand out. He was, sa1d Channing, "the prince of plungers." One of the most interesting ventures was his connection with the buliding of Washington, D. C. That this, "the most attractively planned city in the world," wrote Channing, "exists at all 1s due very largely to the financial genlus of Robert Morris and h1s assoclates, a.1 of whom passed their decilning years in penury." Th1s last, Channing considered a shame. "Republ1cs are proverbially ungrateful," he wrote, "but, considering Robert Morris's serv1ces to the United States, it should

${ }^{34}$ Ib1d., pp. 87-88. In the end-of-chapter b1bl10graphical notes, Channing included this interesting statement: "Henry Cabot Lodge's Alexander Hamliton in the 'American Statesmen' series is one of the most artist1c bits of blographichistorical writing ever done in this country,--and, for that reason, one of the most dangerous for any except the most erudite." (p. 89) 
never have been possible" for h1m to go through what he did. 35

Forelgn affalrs of the new republic necessarily occupled a great deal of space in this fourth volume of the Great Work. Channing introduced the subject as follows:

The promulgation of the Neutrallty Proclamation on April 22, 1793, gave the signal for America's w1thdrawal from old World politics. No event in Washington's administration aroused more interest, few of the deeds that are assoclated w1th his name had more lasting consequences, and not one of them demanded greater courage or betokened more thoughtfulness and foresight. In the first quarter-century of our national history, the fate of America was bound up with that of Europe to an extent that nowadays seems almost incredible. The War for Independence had freed America from the yoke of British m1srule. In the minds of European chancelleries, it had done nothing more; the newly enfranchised States belonged to the Concert of Nations after 1783 fully as much as the English colonies had belonged to $1 t$ before Lexington and Bunker H1l1. Washington, Jefferson, Hamilton, John Adams, and those who worked w1th them, I1berated the UnIted States from this European thraldom,--for a century, the American people lived a life apart from the rest of the world.36

"In 1789," he continued, "the external outlook was as unpleasing as was the internal....The Americans seemed to be relapsing into the colonial condition from sheer Inablilty to keep out of 1t." American leaders were wisely united in their determin ation to keep the United States out of European embroliments. 37

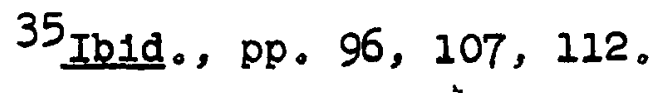

$36_{\text {Ib1d. . p. } 116 .}$

37 Ib1d., pp. 116-117, 127 . 
Channing strained to retain objectivity in dealing w1th the "Cit1zen" Genêt episode. He wrote that

1t is well to recall that Genet, with all his activity, hardly went beyond what Frankiln, Deane, and Lee had done in France before the signing of the Treaty of Alllance, and that the French government had in effect done for the Americans in the matter of military equipment exactly what denet had asked [Secretary of War] Knox to do for h1m。 38

But Channing was overly critical of John Jay and the treaty he negotiated in 1794, especially the portion thereof which dealt with West Indian trade. "At the time and since," he wrote, "1t has seemed remarkable that so high-minded and patriotic a man as John Jay should have slgned an instrument containing so disastrous a stipulation." Jay's "1gnorance" and "error of judgment" were blamed; Channing rejected the 1dea that he had "any purpose of sacrificing the interests of h1s country."39 Channing was unaware, of course, as historians were unt1l only recently, of the role which Hamilton played in undermining whatever chance of success Jay may have had in his negotiations with the British.

Between this introductory treatment of forelgn affalrs and the continuation of that top 1c, which was to occupy most of the rest of the volume, Channing inserted a chapter on "The Rise of Political Parties." There was no such thing as a party in existence in 1789, he noted, "as we use the term

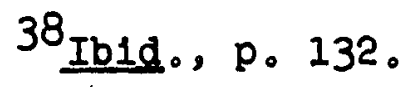

39 Ibido, pp. 142-143.
} 
today:" By 1796, there definitely was.

The differentiation grew out of varying conceptions of the character of the new government and was accentuated by the sectionalism due to divergent industrial conditions, the ever present contests between capitalism and agrarlan1sm, and between conservatism and radicalism. Moreover, the line of cleavage, between those who had and those who had not, had been widened by the disorders of the preceding decade and by the reaction which had placed the propertied classes in power. 40

As Channing presented 1t, Jefferson correctly analyzed that Hamliton, having been unable "to secure a 'strong government' directly through the Federal Convention," was "gradually bullding up such an organization by a liberal interpretation of the Constitution and by executive action." Jefferson thus became the leader of the opposition. Scholar and 1dealist that he was, he seemed "as unfitted to found and dr111 a great party as any man who had appeared in the front rank of American history." Yet, his "political methods were inscrutable." "Almost never has a political party been so efflclently and so secretly marshalled and led," Channing wrote of the Jeffersonian Republicans. The Federalists, he noted, were "reactionary and aristocratic from start to finish and became more reactionary and aristocratic with each successive year." 41

40 Ib1d., p. 151. Here Channing made use of the obv1ous opportunity to refer to Charles A. Beard's Economlc Interpretation of the Constitution. It was "a most valuable contribution to our knowledge of the mainsprings of political activity in th1s epoch," wrote Channing. It was published too late (1913) for him to make use of $1 t$ in volume III; but, as we have seen, he was in agreement with it to a certain extent. $4 I_{\text {Ib1d. }}$ pp. 162, 16.5, 169, 164 . 
Channing gave several reasons for their downfall:

The Federalists had more organization than the Republicans. For one thing they had the advantage of occupying nearly all of the federal offlces. Then, too, presiding over the party's destinies were a dozen men of great ability and administrative experience. Three things were in the way of their continued success. The first was the undoubted unpopularity which Jefferson had managed to cast about several of their measures. Another was the autocratio tone of the leaders. A Federalist letter always begins "It is dec1ded" or "It has been determined,"-- the "1t" meaning that e1ther Hamilton, or two or three men gulded by hIm, had come to a certain conclusion. In similar cases, on the other side of the political boundary, Jefferson's commands take the form of "Our frlends think;" the difference was wide and was vital. The third obstacle to the longcontinued predominance of the Federalist party was the lack of harmony within 1 ts ranks which clustered about the person and pretensions of John Adams. 42

It was in his treatment of Adams that Channing most justified the comment of one historian that his "inclination was in the direction of the Federalists." 43 "The perusal of hundreds of pages of printed matter and a mass of manuscripts has served to relleve John Adams of much of the prejudice that an acqualntance with the annals of his earlier life and the most unfortunate 11terary performances of h1s later years had left on the present writer's mind," confessed Channing. From that point on, the second president's career was evaluated quite favorably. H1s role in preserving peace with France in 1798-1799 was interpreted by Channing as "one of the most

\footnotetext{
42 Ib1d., pp. 169-170.

43 Michael Kraus, The Writing of American H1story (Norman: UnIvers1ty of Oklahoma Press, 1953), p. 236.
} 
notable acts of a remarkable man." Even the notorious "mldnight appolntments," Channing explained away. They resulted from, he wrote, "the goodness of his [Adams'] heart rather than to any selfish desire to defraud Jefferson of any of his rights." 44 Charles A. Beard thought he saw in this last statement an example of Channing's "dry humor"; Carl Russell F1sh was probably more correct in considering it "a deliberate judgment on the man in the study of whose character he [Channing] has made the most profound contribution of the volume. 145

Negatively, Channing justifled to a certaln extent the charge that he was pro-Federalist by his generally critical treatment of Thomas Jefferson in this volume. He respected that figure's ab1lities, but obviously disapproved of the way he ut1lized them on occasion. He even played down the signiflcance of Jefferson's election, the so-called "revolution of 1800." The outcome, he wrote, "turned entirely upon the election in New York and that depended upon [Aaron] Burr's manipulation of New York City politics. To h1m, therefore, the downfall of Federalism was ultimately due." Channing's conclur sion: "It 1s perfectly truthful, therefore, to say that a change of less than two hundred and fifty votes in the clty of New York...would have given New York's vote to Adams and made

\author{
44 H1story, IV, pp。182, 205, 241 。 \\ ${ }^{45}$ Charles A. Beard, New Republ1c, XI (July 7, 1917),
} p. 282; Carl Russeli F1sh, Miss1ss1pp1 Va1ley H1storioal Review, IV (September, 1917), p.246. 
h1m Presldent w1th seventy*seven votes to s1xty-one for Jefferson, - of such was the Revolution of 1800."46

\section{Channing did conslder Jefferson's first Inaugural}

address "one of the most noteworthy documents that ever came from his pen." It "deserves the careful attention of every one, because the principles therein enunclated underlie democrat1c government in every age and clime." Channing also admitted that "1t would be difficult to find a more effective b1t of administration than that of our national affa1rs in Jefferson's first term。" But more typical is this comment, made with the Tripolitan War in mind: "Jefferson's bellicose attitude in the early years of his presidency 18 well worth bearing in mind in view of his later determination to keep the United States out of the world-wide war regardless of what seemed to many persons to be the national honor." 47

46 H1story, IV, pp。236-237. Chann1ng was unw1ling to concede that the controversy centering around the Alien and Sedition Acts and the Kentuoky and Virginia Resolutions had any significant effect on the election. ( $p$. 232) He was even unwliling to condemn the Allen and Sedition Acts, and minimized the Ir harshness and injustice. (p. 224) One historian commented wrongly that "Channing was rather friendly to Jefferson." (Kraus, The Writing of American History, p. 236) Channing became a rather good friend of Albert J. Beveridge; the1r "mutual dislike of Jefferson" helped draw them together.--claude $G_{\text {. Bowers, }}$ Beveridge and the Progressive Era (Cambridge: Houghton Miffin Company, 1932), p. 552. Another historian noted that "Channing alone [of Dodd, Jameson, Farrand, and several others who alded Beverldge by reading the manuscript tof his Ilfe of John Marshali] seemed to have accepted Beveridge's [oritical] treatment of Jefferson."-Tracy E. Strevey, "Albert J. Beveridge," In W1lliam T. Hutchin-

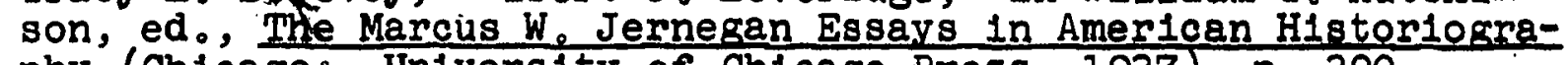
phy (Ch1cago: University of Ch1cago Press, 1937), p. 390 .

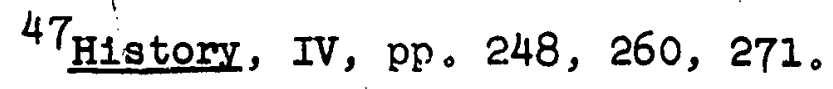


"The most significant achlevement of Jefferson's first administration was the procurement of Lou1siana," 48 wrote Channing. The Lou1slana Purchase had been the subject of his Ph.D. thes1s; 1t here occupled two well-written, but slanted, chapters. Well-written because Channing always did better when he had a central theme as opposed to dealing with diverse material; slanted because Channing emphasized how the purchase played havoc with Jefferson's consitutional theorles:

Jefferson, the apostle of the right of man to govern himself according to certain unallenable laws, had negotiated through h1s representatives a treaty acquiring some thousands of Speniards and Frenchmen together with an ent1rely unknown quantity of North American Indians. Government "existed by consent of the governed," but the consent of not one of these persons had been asked. Moreover, in the existing condition of affairs with the world at war and a very large proportion of these recently purchased human beings by no means enthuslastically affected to their new owners, whatever government was established, must be somewhat autooratic. What right, Indeed, had the United States to buy lands and rivers without the consent of the Inhabitants or with 1t? Was the Constitution a pact between soverelgn States and 11 mited to the area of 1783 or did the American people form a nation? Jefferson and h1s co-workers had declalmed loudly agalnst the 1dea that the United States was something more than a bunch of soverelgn States working together under an agreement for certain limited purposes and had demanded that this compact should be strictly construed that the rights of the co-states should suffer no 1mpairment. Possibly the most interesting thing that came out of the Loulsiana Purchase was the statement by Jefferson to Breckinr1dge, August 12,1803 that after the treaty was ratified and exeouted an appeal must then be made to "the nation" for a confirmation of an act wh1ch "the nation" had not pre$v 10 u s i y$ authorlzed--only five years after the

$48_{\text {Ib1d. . . p. } 275 .}$ 
Kentucky Resolutiong and the1r author was writing about "the nation!" 49

Somewhat carried away w1th the significance of the purchase, Channing speculated:

had there been no Loulslana Purchase there would have been no Missour1 Compromise, no Texas annexation, no Mexican War, no Oregon boundary! The Kansas-Nebraska Act would never have been passed and there would have been no War for Secession w1th 1 ts attendant orgles of Reconstruction. But the star of destiny otherwise determined, and $1 t$ is not the function of history to question.50

According to Channing, "The years immedlately follow-

Ing the Loulsiana Purchase were among the most troublous in our annals。" One problem was boundarles: "From this point, the matter of the bounds of Loulslana passed 1nto the hands of the diplomatists, and when they got through w1th 1t, by the Florlda treaty of 1819, the historians took 1t up and have been at 1t ever since." More spec1f1cally, however, Channing had in mind Burr's consp1racy. Aaron Burr, he wrote, was "one of the most extraordinary and lamentable figures of American political history." 51

49 Ib1d., pp. 333-334. Chann1ng was not too concerned with the problem of who should get "credit" for the purchase. He relegated h1s comments on that subject to a footnote: "It is not difficult to apportion the credit for this transaction. Napoleon, for reasons having nothing whatever to do with the United States, suddenly determined to get whatever he could for whatever title to Loulslana he had. He threw the province, so to speak, at Iivingston, Monroe, Madison, and Jefferson; and they share between them--equaliy--whatever credit there was in catching 1t and holding 1t--that is a11." (p. 319)

$$
\begin{aligned}
& { }^{50} \text { Ib1d., pp.334-335. } \\
& { }^{51} \text { Ib1d., pp。335, 331, } 172 \text {, }
\end{aligned}
$$


Another part of the aftermath of the purchase was the Florida problem, which flared in 1805. Channing really became critical here. He saw this as "a species of retributive justice for the violation of the Constitution in the procurement of Loulsiana and the Immorality of recelving stolen goods from the greatest cutthroat of modern t1mes." 52

The second most significant development of Jefferson's first term was the assault on the federal judiclary. Here, too, Channing found opportunity to be critical of the Jeffersonians. The most important aspect of this attack was the attempt to Impeach Samuel Chase, Associate Justice of the Supreme Court. Channing admitted that Chase, with his partisan harangues from the bench, was an anachronism, but he serlously doubted that that was "a sufficlent reason for straining the Constitution to remove him from the bench, embltter the last days of the life of a Signer of the Deolaration of Independence, and set a precedent that would destroy the greatest part of the protective efficiency of the federal judiclary and greatiy injure that of the state judiclaries."53 However, "Jefferson's domestio difficulties were trifling in comparison with those that befell in connection with International affa1rs," Channing noted. He admitted that Jefferson was "only partly responsible" for these. 54 From

$$
\begin{aligned}
& 52 \text { Ib1d., p. } 348 . \\
& 53 \text { Ib1d., p. } 287 . \\
& 54 \text { Ib1d：，p. } 349 .
\end{aligned}
$$


this point on, Channing's narrative is largely concerned with these international affairs, particularly, of course, the problems leading to involvement in the War of 1812 , and the conflict 1tself. Channing wrote well about these developments, and usually succeeded in remaining objective. "Sentiment played a large part in dictating the discussions and acts of that day, as well as of our own," he stated.

The sayings "The flag covers the cargo," "Free ships make free goods," "The freedom of the seas," and others of the kind have given a false glint to the whole debate. Property that is rightfuliy spoken of as private and neutral, while on the land in a neutral country, ceases to be such the moment it finds itself on the ocean on the way to a bell1 $\mathrm{B}^{-}$ erent, no matter how directly or indirectly it may go. On the contrary, such property partakes of a semi-military character, however incffensive it may seem in 1tself to be, provided it can in any way be used for the support of clvilians engaged in supplying military forces with recrults, munitions, or food. A neutral ocean commerce carrier engaged in the transportation of goods to a belligerant in ninety-nine cases out of a hundred is giving ald and comfort to one country at the cost of lives and treasure to the other, and in so far is performing an un-neutral act. 55

Or one of the leading polnts of conflict between the United States and Britain, Impressment, Channing made rather contradictory remarks. In one place he agreed that it was an "abominable" practice, but in another he played down 1ts extent and significance and doubted the adequacy of "the ev1dence la1d before Congress by Madison and belleved by him to be a complete justification of war on land and sea with all

$55_{\text {Ib1d. }}$ pp. 352-353. 
1ts k1llings, and burnings, and p1llagings, and doubtfulness of result that attends any exercise of arms." 56

Channing played down the amount of suffering which resulted from the Jeffersonian Embargo, except in V1rgin1a. Indeed, he talked a great deal about the "constructive" effects of the measure on New England. The high price of 1liegaliy Imported goods, he noted, "gave would-be manufacturers their chance." "Northern manufacturing owed 1ts rebirth to the Jeffersonians, an outcome of thelr pollcy that was certainly very far from their desire. " 57

For a work dealing primarily with national political history, this volume contains amazingly little on presldential elections. The election of 1804, for example, got approximately one page. "Jeffersonianism was st1ll supreme," Channing concluded, "but unless there was a modification in 1ts pol1cles, the political future was by no means secure." 58

Channing traced the modifications in policy by the James Madison and James Monroe administrations through the Non-Intercourse Act, Macon's B11I \#2, and the Cadore letter, to the declaration of war.

In 1811 , 1t became clear that a large part of the people of the United States was wearying of inaction, was content no longer to submit to insults, and was conscious of a growing spirit

${ }^{56}$ Ip1d. , pp. 369, 483 .

57 Ibid....pp. 388-389.

58 Ib1d., p. 398 . 


\section{8}

of nat1onal1sm. In May, an Amerlcan frigate fired on a British ship-of-war; in November, the battle of Tippecanoe expressed western protest against British interference with the Indians south of the boundary 11ne; and in December, new men filled with aggressive natignalism came into prominent pol1tical positions. 59

Monroe himself was held largely responsible for the declaration of war. He "came into the office with a serious and firm conviction that the American government must resent the usage whlch it had recelved and was recelving from forelgn powers, not by arguments and protests merely, but by an appeal to arms," wrote Channing. "These oplnions he held forth day and night and was more responsible than any one else for the declaration of war." "Proceeding onward with eyes blinded by a happy Fate and acting under the influence of Monroe, on June 1, Madison recommended a declaration of war." 60

In Channing's treatment of the War of 1812, 1tself, the role of the navy stands out. He relied rather heavily in his account on the works of Henry Adams and Alfred T. Mahan, both of whom recelved praise in his blbllographical comments.

59Ib1d., pp. 440-441. Channing made brief evaluations of both Madison and Monroe. "Like so many men of that day," he wrote, "Madison combined scholarship with politics. He is not in the f1rst rank of Amer1cans w1th Washington, Jefferson, and Lincoln; but as a constructive statesman, he stands almost alone by reason of the acumen with which he judged of the possible and impossible, conjolned to a knowledge of the present and the past." (H1story,: III, p. 477) on Monroe, Channing was both more brief and more devastating. "James Monroe," he stated, "was one of those men of pers1stent med1ocrity from whom useful and attractive Presidents have been made." (H1story, IV, p. 314)

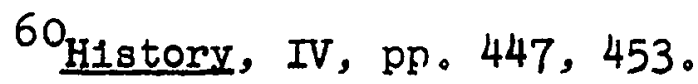


Channing did an excellent job of relating European and American develcpments in his final chapter, concluding that the significant thing about the Treaty of Ghent was that "It was a treaty of peace to free Britaln's hands for the coming conflict with Napoleonism that was to end on the battlefield of Water100." 61 He was a good deal more lenlent toward New England in his treatment of the Hartford Convention than most historians had been. He concluded this volume, and set the scene for the next one, by describing the reaction to the end of the war:

The revulsion of feeling was tremendous, Without walting to look into the treaty "everyone passed from gloom to glory" and drinking and congratulations were the order of the afternoon and the evening. The ratified treaty was at once made public. Within twenty-three hours a copy of 1t went from Washington to New York, - -an unexampled swiftness of transit. Everywhere as the news came "Peace--Secur1ty--Prosper1ty" was the cry; scholars were dismissed from school, flags were exhibited, even Harvard University was "splendidly 1lluminated in the evening, on this happy occasion." Prices of staple American products bounded up to the gratification of farmer and planter; prices of imported goods rere cut in halves, greatly to the sorrow of merohant and 1mporter. Everywhere, throughout the land, interest in forelgn affairs and in home politics ceased. The American Nation, with Its back to Europe and 1 ts face to the West, addressed Itself to the solution of the problems of the Nineteenth Century. 62

When one attempts to discern Channing's over-all Inter-, pretation of the 1789-1815 period, some problems emerge. Though he was critical of such nineteenth century historlans

$$
\begin{aligned}
& 61_{\text {Ib1d., p. } 557 .} \\
& 62_{\text {Ib1d., p. } 564 .}
\end{aligned}
$$


as H1ldreth and von Holst, he did not manage to break with their Federal1st-Whig-Republican approach to the Federalist era as much as he seemed to think. Hamilton still came off quite well and John Adams even better. As for the Jeffersonian portion of the period, Channing was obviously influenced by the work of his mentor, Henry Adams. Jefferson was not all bad, but Channing's emphasis tended to be on the problems Jefferson had in conforming his philosophy to the realities of politics.

Channing obviously meant, by h1s comment in the letter quoted at the head of th1s chapter about the fourth volume having "struck a new note," that it was being recelved better than the earlier volumes had been. He made 1 t $\in$ ven clearer in other letters that that was his meaning. "Everyone seems to like Volume IV," he wrote to Brett on one occasion, and, on st1ll another: "If it is true that the sale of books is in inverse proportion to review laudation, we wouls [s1c] better hire somebody to pitch into yours truly."63 He was not readIng the reviews very carefully. True, they were generally favorable again. But, for the first time, one review left an over-all critical impression. And most of the favorable ones found more to complain about in this volume than in any of the first three.

The critical review was by William E。 Dodd, and appeared in the Dlal. Dodd did manage to say some nice things

${ }^{63}$ Channing to Brett, September 20 and October 16, 1917 , Macmilian Collection. 
about Federalists and Republicans, but always qualifled. "If his [Channing's] work fa1ls to show, as one might wish, the evolution of soclety in America, the meaning of events, and the Influence of 1deas, it is a useful reference work, "Dodd wrote. He filled his review with little innuendoes, like "1t may be doubted whether Professor Channing has read," and "1t may be doubted whether he knows." After speculating on the amount of time it would take for Channing to complete the entire set, Dodd even seemed doubtful of whether it was worthwhile: "Thirty years to a work which of necessity must be antiquated before $1 \mathrm{t}$ is finished!" Dodd concluded by acknowledging that the volume was "difficult to appralse justly." It was "substantial, informing and useful," he sald, but brought to light nothing new, and showed no evidence of very keen insight. 64

Channlng was particularly proud of the "very laudatory" review of this fourth volume of h1s areat Work by John Spencer Bassett in the American H1storical Review and the "very complimentary" ones by Charles A. Beard and Carl Russell Fish in the New Republic and Mississipp1 Valley H1storical Rev1ew, respectively. 65 Actually, the praise of all of these reviews is qualified a great deal more than Channing's evaluations lead one to belleve.

\footnotetext{
${ }^{64}$ W11liam E。 Dodd, Dial, LXIII (July 19, 1917), pp. 6063.

${ }^{65}$ Channing to Brett, October 16, 1917, Macmilian Collection.
} 
Bassett's pra1se was only slightly qualifled, but qualified st111. "It does not seem extravagant to say that for the perlod with which this volume deals Professor Channing must be regarded as having set a new light in the historloal heavens in the United States which none of h1s successors w111 1gnore," Bassett procla1med. "If crit1cs find flaws in his treatment they w11l probably flnd small ones, and they w111 have to flght hard for the1r content1ons." But he went on to find some of those small flaws himself. And, more importantly, he felt that "1t is as an old-style historian that we must rank Professor Channing. For him the pol1tical thread is the clue to follow. He gives the flrst chapter in the volume to social conditions, and thereafter he goes on from one pol1t10al event to another." 66

Beard wrote a typloal Beardian reviow in the New Repub11. There was praise: "It 1s not too muoh to say...that whoever desires a fresh story of the perlod covered by th1s volume, founded on the latest Investigations of soholars and concelved In a manner thoroughly acceptable to the leading lights of the American H1storical Assoolation, must turn to these pages." Channing was a "true soholar," with "a mind of great natural powers." But there were also orft101sms and Innuendoes. Channing's mind, for example, "had it been devoted to a different type of historical construction, could have

66 John Spencer Bassett, American H1storscal Reysew, XXIII (Ootober, 1917), pp. 189-192. 
contributed st111 more to our understanding of the early phases of American politics." "No sportive fancles enliven (or mar) Professor Channing's pages," sald Beard of Channing's style. "If he reads Tom Sawyer or Plays for Puritans during vacations, he carefully conceals the fact when he writes his History of the United States." And finaliy, Beard lived up to his reputation when he criticized Channing for reversing things in saying that economic factors accentuated an already-developing 1deological split between Federal:Lets and Republicans. 67

Fish's praise was least qualifled. He noted that Channing's volumes "Intensify in value as they grow in number, for the advantages that $11 \mathrm{e}$ in a review of American history by a single mind multiply as the perlod revlewed lengthens." But even he found cause for complaint. He thought Channing's account of the Hartford Convention "unduiy brief and colorless" and his account of the peace negotiations at ahent "Inadequate for the general reader." More Importantiy, Fish considered 1t "one of the main limitations" of the volume that it was so overwhelmingly concerned with national politics. 68

Perhaps the most telling critlc1sm of Channing's fourth volume is that of his grandson, who ordinarily was very

\footnotetext{
67 Charles A. Beard, New Republ1s, XI (July 7, 1917), pp. 282-283.

68 Carl Russell F1sh, M1s81s810p1 Valley H1storlcal Rev1ew, IV (September, 1917), pp. 243-247. The other rev1ews, mostiy favorable, but most with their complaints also, were: Amer1can Pol1tical Sclence Rev1ew, XI (November, 1917), p. 793; American Review of Reviews, LVI (August, 1917), D. 215; Athenaeum, XIII (October, 1917), p. 530; Nat1on, CV (December 20, 1917), pp. 692-693; and spectator CXX (January 5, 1918), pp. 16-17.
} 


\section{4}

hesitant to criticize. Here, however, he felt obligated to agree that Channing emphaslzed national politics too much (the "main critic1sm") and that he seemed not to have had time "to assimilate all the material in a selective and digested arrangement." He even directed a mild reprimand at Beard, notIng, arter quoting some of Beard's most praiseful statements, : that the volume "does not seem to l1ve up to these h1ghest of recommendations." 69

${ }^{69}$ John Channing Fuller, "Edward Channing: Essays on The Man, The Teacher, and The Writer" (Unpublished sen1or honors thes1s, W11liams College, 1943), pp. 120-122. 


\title{
THE PERIOD OF TRANSITION
}

\begin{abstract}
"The development of transportation in the years following the Treaty of Ghent is the most significant factor in American life between the inauguration of Washington and the firing on Fort Sumter." Is this statement true? Explain at length. 1
\end{abstract}

Edward Channing first mentioned his fifth volume in his correspondence w1th Macmillan's president, Gearge P.Brett, In May, 1917, the very next month after volume IV was pub11shed. He was thinking about calling 1t "The West and Jacksontan Democracy, 1815-1850." He d1d not teach the fall semester, for he wrote to Brett again in November that he was headed West for research. He mentioned, as places he intended to v1s1t, Mad1son, Salt Lake C1ty, Berkeley, and, on the way back, New Orleans. Before he was through, he visited all those and more--though he seems not to have been concentrating on research at all of them. "We, have been here two weeks now," he wrote from Santa Barbara on January 15, 1918, "basking in the sunshine, watching the bathers, and motoring around the country--getting up steam for work the second half year. I hope that you have had enough coal; but you people seem to have had a very hard time. It makes one feel horribly selfish to be so warm when so many good people are suffering." By

${ }^{2}$ An Edward Channing examination question, from Lawrence Shaw Mayo's notes as Channing's assistant in the period 1913 to 1918, Harvard Un1versity Aroh1ves. 


\section{6}

February 7 Channing had returned and was writing to Brett, "I am back from California and what a welcome the weather man has given me! Moreover, I have little coal in my cellar, my coal dealer has none in his bins, and no prospect of getting any unt11 the 1ce breaks up. But I am happy, although living at a club," he went on. "Mrs. Channing is in Washington looking after grandson's education, so when we shall begin housekeeping is problematical. Here I am at the old stand," back at work, he concluded. ${ }^{2}$

Channing considered his trip to the West well worthwh1le. He had written President Lowell that he felt he "could not write Vol. V. Without visiting California."3 while in Berkeley he had written to Brett:

At Madison and Salt Lake I gathered much material, local color, and geographic sense for Vo1. 5 . Here I have been a month working in the Bancroft Library and think that I have got an Insight into TransAppalachia that I could never have got from printed books. If I can display this on the printed page the sales of the H1stony w1Il be greatly increased. 4

There was another benef1t, too: "I have met a lot of people and made many frlends of those who had known me only through my books." 5 When Channing looked back at the trip a year

\section{${ }^{2}$ Edward Channing to George P. Brett, May 17 and} November 1, 1917, January 15 and February 7, 1918, Edward Channing File, Macmilian Authors Collection, Manusoript Div1sion, New York Public L1brary.

3Edward Channing to A. Lawrence Lowell, December 9, 1917, Edward Channing folder, A. Lawrence Lowell Papers, Harvard Un1versity Arch1ves. Collection.

${ }^{4}$ Channing to Brett, December 25, 1917, Macmillan

$$
5 \text { Ib1d. }
$$


later, he saw it this way:

The net result of my Western trip is the belief that if I can make a reasonably successful volume V-which w11l concentrate attention on me and my historlcal work that we ought to be able to double or treble the sales. There is no good book on those years between the close of Henry Adams and the beginning of Rhodes, and if I can write a worthy volume, it w11l be recelyed with acclaim,--for McMaster is a nightmare.6

The summer of 1918 Channing spent in Cotu1t. A letter he wrote from there described rather well what volume $\mathrm{V}$ was to become:

Vo1. 5 is whacking along and I have written b1ts of vols [s1c] $6,7,+8$ as I passed on in my lectures. I am making a practlcally new book of these last four volumes. The first third of 5 w11l be a study of the humanitarian and me [c] hanical readjustment of the years 1815-1850-transportation [,] settlement of the western country, abolition, labor, prohibition, 11terature, etc. The last third will be on Texas, Cal. [S10] Oregon + Mexican War. Between w111 come Jackson and $h 1 s$ dolngs--also h1s successors.7

"May I not inquire as to whether the President and fellows wiah to have me teach for the second half of next year," Channing asked President Lowell in a letter dated Maroh 25, 1919. "Or would they prefer to retire me for good and all," he continued. "Personally, I should be very glad to teach for the second half of next year, as I enjoy the contact with a large class of students. But I leave the question entirely in your hands." He was working away on volume $V$.

$$
\begin{aligned}
& 6_{\text {Ib1d., January 2, } 1919 .} \\
& 7_{\text {Ib1d., July 2, } 1918 .}
\end{aligned}
$$


"I am going down to Charleston next week to study nullification on the spot," he sa1d. A short time later he returned from the trip, saying he had found "a very interesting b1t of material," and thanking Lowell and the Corporation for rellevIng him of his teaching duties for the next fall semester. "Th1s will enable me to finish my fifth volume," he wrote, "or, at all events, to bring it near to a conclusion, so that I can send 1 t to the printer about a year from now." 8

Channing became very dejected before he finaliy fin1shed the flfth Installment of his Great Work. He went to Cotu1t again for the summer in 1919. "You w11l be glad to know that I have been running ahead under full pressure on volume $V, " 9$ he wrote Brett. But 1t was whlle he was there at "No1sy Point," strangely, that dejection set 1n. High taxes apparently started 1t, but from this beginning he became concerned about h1s problems in general. Here is the way he described the s1tuation to Brett:

Personally my taxes are so large that I am at my wit's ends. I would like to seli No1sy Pt + give up [the house in Cambridge at] 74 Sparks $t$ go to boarding; but my family is unhappy at either thought--to say nothing of both. So I am getting along without a man. I st111 have Miss Moore; but I may have to let her go--then good bye to the History after Vol. 5. I should be sorry to give it up because I have masses of materlal collected for Vols. $6,7,8$. We will finish 5 at any rate. I told you the Corporation had relleved me of teaching

${ }^{8}$ Channing to Lowell, March 15 and April 7, 1919, Lowell

${ }^{9}$ Channing to Brett, July 5, 1919, Macmilian Collection. 
unt1l Feb, so that job can be done. After that we

In December, 1919, however, things began to happen which should have brought Channing out of his pessimistic att1tude. He attended the meeting of the American Historical Association in cleveland that month and was elected president. According to h1s own account, he devoted a great deal of time to the duties of that office during the next year. "I sincerely hope that the two 'babes in the woods, ' namely [John Spencer] Bassett [Secretary of the association] and myself are not making any horrid breaks," he wrote to J. Franklin Jameson in Apr11, 1920. "We are both of us sitting up nights and getting thin in our efforts to serve our country and the Assoc." But Channing seems to have maintained his usual 1solation to a remarkable extent also. He wrote to Jameson in September apologizing for missing a meeting and giving as his reason that "vo1. $V$ must go to the printer as soon as poss1ble."ll And he wrote to M1ss Patty Washington, assistant treasurer of the association, returning a book that had been Bent to him for comment:

I never write puffs for publishers and therefore the thing for you to do is return the book to the gentleman with some very pleasant statement, to the effect that President Channing is busy or unwell or something. If you do not feel able to do th1s, you might turn $1 t$ over to $\mathrm{Mr}$. Secretary Bassett, for I have no doubt he would be very glad to have the

${ }^{10}$ Ib1d., July 20, 1919.

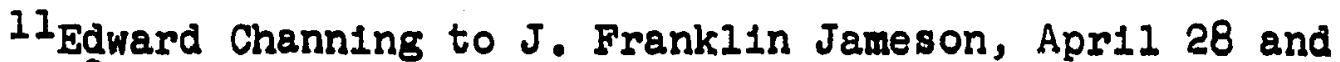
September 28, 1920, John Frankin Jameson Collection, Manuscript Div1sion, Library of Congress, Washington, D. C. 
books and write the endorsement. At any rate, be very kind to the gentleman and don't send the books to

Verry truly yours
Edward Channing 12

Channing $d 1 d$, of course, attend the meeting of the association at Washington, December 28-30, 1920. He delivered a presidential address entitled "An Historical Retrospect." In $1 t$, he showed a pessimism in relation to things far more signiflcant than his own personal problems. He showed, indeed, that his bellef in progress, stated so forcefully in his preface to the Great Work in 1905, may have been somewhat shaken by World War I and its aftermath. He called the hundred years from 1820 to 1920 the "Wonderful Century." But he ser1ously doubted $1 f$ some of the developments of that perlod were so good.

Channing drew very heavily on his fifth volume for the president1al address. Indeed, he may have considered the address a nu1sance because it took h1m away from the Great Work. 13 "The hundred years between 1820 and our own time are w1thout counterpart in the h1story of the world," he told the assembled members of the historical profession of America. War, he thought, had a great deal to do with 1t, for the new era began at the end of the long serles of wars extending

12 Edward Channing to Miss Washington, Apr11 21, 1920, Amerloan Historical Assoclation Collection, Secretary File, Manuscript Division, Library of Congress, Washington, D. C.

13Herman Ausubel, Historlans and Their Craft: A Study of the President1al Addresses of the American H1storical Assoc1ation, 1884-1945 (New York: Columb1a Un1versity Press, 1950), p. 70 . 
from 1756 to 1815. "War in 1tself is the most dreadful scourge that afflicts humanity. It has another side, however," he cautioned,

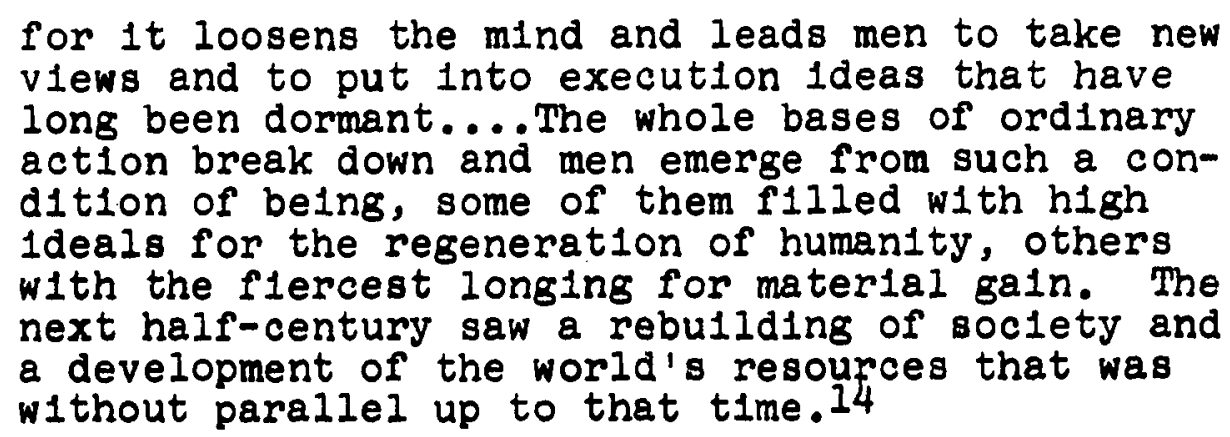

A major thesis of volume $V$ was stated here in the presidential address also. "The most significant fact in the development of the United States between 1815 and 1865," he sa1d, "was the installation of new systems of transportation of men and goods and the transmission of intelligence and administrative orders." Some of the results of this were good.; others were not. In both industry and agriculture, for example, Channing considered one of the final results of changes set in motion by innovations in transportation to be that "the laborer has lost that touch with nature which gave joy to his work." Indeed, there is a touch of nostalgia ev1dent throughout Channing's address. He referred once to the "good old colonial days," and he lamented that "The Jeffersonian 1dea of the dignity of the individual has disappeared. Now, men and women belong to a soclety and not to themselves."15

\section{Edward Channing, "An Historical Retrospect," Amer1can} Historical Review, XXVI (January, 1921), p. 193. 
He doubted the value of changes in the educational system:

"But may we not ask ourselves as to how super1or our educatIonal system is to that whlch produced RaIph WaIdo Emerson, Edgar Alien Poe, Washington Irving, and W1111am G1lmore Simms?"16 He doubted the value of constitutional amendments thirteen through nineteen:

In the changing march of political and social 1nstitutions, due in great measure to the ever Inoreasing mobli1ty of men and 1deas, the change from federal republican institutions to those of a more or less unifled democracy has been inevitable and the change 18 not yet complete. It may well be asked, however, whether th1s plecemeal fitting of our fundamental law to new ldeas 18 the best way of going about 1t. 17

And finally, he cast doubt on the desirab111ty of al1 the changes wrought by the "Wonderful Century":

In all this, in the evolution of the greatest Industrial soclety that the world has ever seen, have we gained or have we lost? Are men and women to-day happler and better off, political1y, spirltually, mentaliy, moraliy, and physically, than our ancestors. Were in the days of James Monroe, John Quincy Adams, John C. Calhoun Henry Clay, Daniel Webster, and Andrew Jackson? 18

$$
\begin{aligned}
& 16 \text { Ib1d., p. } 200 . \\
& 17 \text { Ib1d., pp. 201-202. }
\end{aligned}
$$

28 Ib1d., p. 202. Ausubel, in Historians and The1r Craft, anaiyzed Channing's president1al addross rather well. He emphasized Channing's "past-mindedness": "Channing, who had long considered 1 t his mission 1 to study and write without malloe,' did not use history to exalt the present at the expense of the past; he showed in 1920 the same pastmindedness that he had shown flfteen years before when he wrote: To estimate Amen1cans. of the past by the conditions and Ideas of the present day 18 to give a false plcture to the reader and the otudent. " Ausubel contended that Channing's investigation "equipped him not so much to guide the present as to challenge and deflate 1t." (pp. 70-71) He also noted 
One thing which happened at the American Historical Association meeting which probably did even more than his election as president to cheer Channing up personally was the dinner given in his honor at the cosmos Club by a group of his former students. An inscription on the program read: "To Edward Channing who so worthily maintains the traditions that were established by Herodotus...a tribute of respect and admiration, of gratitude and affection, has been pald by a few of those whom he has taught to study, and to write."19 The menu, which Included as a beverage "Punch a la Elghteenth Amendment," had on 1 a humorous carlcuture of Channing from the Harvard Lampoon. 20 Among those present were George P. WInship, Sidney B. Fay, Wllliam B. Munro, Everett Kimball, and Waldo G. Leland. 21 One result of this occasion was the placing of a bronze tablet above the door of Channing's study, W1dener 417, with this inscription:

that "Channing did not talk about what the content of history should be. Instead, he showed, by using political, economic, social, and cultural data, how broad his view of the past was, or better st111, how much broader it had become in the period since he had started to work on the magnim opus." ( $p$. 335)

19 From the copy in the Channing "Quinquennial" folder, Harvard University Archives.

$20_{\text {Ib1d. }}$

21"A Tablet for Professor Channing," Harvard Alumn1 Bulletin, other information unknown. A copy of this brief article was found in the "Resignation" folder in the possession of Elizabeth Channing Fuller, Chatham, Massachusetts. 


\author{
EDWARD CHANNING 178 \\ TEACHER OF HISTORY \\ AUTHOR OF "A HISTORY OF THE UNITED STATES" \\ THE FIRST OCCUPANT OF THIS STUDY \\ THIS TABLET HAS BEEN PLACED HERE IN 1921 \\ BY A FEW OF THOSE WHOM HE HAS TAUQHT \\ HOW TO STUDY AND TO WRITE 22
}

Among those unable to attend the dinner, but who contributed to the tablet, were Charles Francis Adams, Carl Russell Fish,

E. B. Greene, Lawrence Shaw Mayo, Roger B. Merriman, Samuel

Ellot Morison, and Frederlc Logan Paxon. 23 Channing told one of his friends that he was most touched by the dinner, given, as he said, in honor of one "who had been nothing but an old bear all his life." 24

Samuel Ellot Morison called the years following World War I Channing's "harvest season"; he finally began to gain recognition for his work. In addition to the Amerlcan H1storical Association presidency and the dinner, he recelved an honorary degree of LI.D. from the University of Michigan in 1921.25

Channing was doubtless slowed down somewhat in the completion of his fifth volume by the various activities in relation to his presidency. He finlshed it not long after the

22Ib1d. The tablet is st1ll there; the study is now occupled by Samuel Ellot Morison.

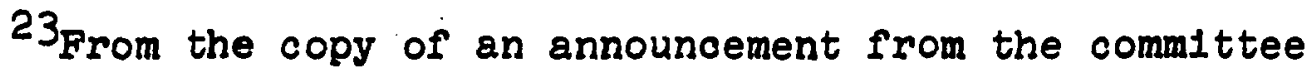
in charge of the affalr to all the contributors, in the "Quinquennial" folder.

24 Samuel El1ot Mor1son, "Edward Channing: A Memo1r," Proceedings of the Massachusetts H1storical Association, IXIV Toctober, 1930-June, 1932), p. 282.

25 Ib1d., p. 283. 
meeting, however, for he wrote to Brett on March 31, 1921, that It was done. "I think it a humming good job," he added. Publication was delayed still further by a nation-wide strike of printers and binders. 26 The Period of Transition was finaliy published in October.

It started with a chapter ent1tied "The Wonderful Century." In this period, Channing noted, the American mind, previously concerned with political matters, "suddenly turned to other problems of human existence and became renowned for fertility of 1nvention, for greatness in the art of 11 terary expression, and for the keenest desire for the amelioration of the lot of human1ty." 27 war, sa1d Channing, was responsible for much of this. Some of his commenta on war and transportation here sound very much l1ke those he expressed in the president1al address, but they bear quoting at some length:

In 1tself, war is a frightful scourge; but in 1ts effects it oftentimes has produced most beneficent results. Wars and revolutions lead to readjustments In social relations, in politioal affairs, and in the mental outlook of nations and of races. Ordinarliy, our rules and regulations, our ordinances, and our laws are directed to the preservation of human Iffe, to the proteotion of Ind1vidual I1bert1es, and to the conservation of property. In war, on the other hand, our design 18 to k111, to destroy, and to make existence painful to men and women on the other side of the boundary 11ne. In suoh t1mes, the mind breaks adrift from 1 ts everyday moorings and turns to thoughts and theories that in peaceful hours seemed fantastic and inoapable of attainment.

${ }^{26}$ Channing to Brett, March 31, 1921, and Brett to Channing, May 16, 1921, Macmilian Collection.

27 Edward Channing, A History of the United States, Volume V: The Perlod of Transition 1815-1848 (Hew York: The Macmilian Company, 1921), p. 2 . 


\section{6}

War leads to a loosening of the mind, to a breaking of assoclations, to new thoughts and groupings; and humanity leaps from one stage of civilization to another. In the thirty-f1ve years after 1815, men and women threw off the shackles of the past: they exalted the position of the individual in soolety, burst the bonds of education and religion, exper1mented with schemes to better human life, sought the abolition of slavery, and the reformation of drunkards and crimizicis. All this led to the giving the masses of the people more direct participation in the government of town, c1ty, county, State, and Nat1on. Unfortunately w1th the good there was also the bad, for war leads to a slackening of the moral sense, and to an increase in the desire for rapld gain. In such times, men forget their obligations to thelr fellow men and embark on speculative ventures without other thought than seif-enrichment. Th1s was particularly true after the fall of the Napoleonlc Emp1re, for great discoverles in mechan1cs, in chemistry, in physics, in b10logy, and in the medical sclences gave opportunities of pecuniary profit that the world had never dreamed of before in historic times. For America, the most 1mportant of them all was the application of the new Inventions to the transportation of persons and of goods and to the transmission of intelligence and of administrative orders from one part of the country to another. Modern life in all 1ts branches from day to day, in peace and war, depends upon the mobility of men and of things, for it is this that makes possible the association of human beings for the prosecution of soclologlcal, political, and economic objects. 28

Channing realized that, among other things, he was bucking the frontier interpretation of American history put forward by his colleague, Frederick Jackson Turner. He added a footnote at the end of the above quotation: "For a radically different view of the main springs of our national development from that given in the text," he suggested, see the works of

28

Ib1d., pp. 2-3. 
Turner. ${ }^{29}$ At least one historian of note, Paul H. Buck, considered Channing's emphasis on transportation to be "fully as Important as Turner's thes1s."30 It did not, of course, acquire one-tenth the notorlety of Turner's frontier hypothes1s. Part of the problem was that Channing did not really make the transportation thesis an integral part of h1s h1story of the perlod. Sald one critic:

On at least one occasion, Channing was content frankly to state his thesis, leave it suspended in midalr, and hest1ly return to safer ground. Upon the rejection of Professor Turner's view of sectlonaliem and the West as "mainsprings of our national development," he subst1tuted "the mobility of men and things" as the most signiflcant cause of national progress. Content with a brief explanation, the generalization was pushed no farther, and 1 t was
associated with virtualiy no subsequent developments. 31

The critic had a point. But he got carried away with 1t, as Channing himself sometimes did. In the first place, Channing sald a great deal more than that "the mob1lity of men and things" was the most s1gniflcant cause of nat1onal progress; the extensive quotation above 1s alone enough to show that. More importantiy, th1s orltic drastioaliy overstated h1s case when he sald that Channing did not associate his thesis with any subsequent developments. Actueliy, Channing attempted

\section{Ip1d., pp. 3-4.} Massachusetts.

${ }^{30}$ Interview with Paul H. Buok, June 9, 1967, Cambridge,

31 Ralph Ray Fahrney, "Edward Channing," in W1111am T. Hutchingon, ed.", The Marcus $w$. Jernegan Essays in American H1s torlography (Ch10ago: Un1versity of Ch10ago Press, 1937), p. 304 . 
to relate the thesis to many things later in the volume, sometimes with success and sometimes not so successfully. He connected 1t with the westward movement, industry, agriculture, clt1es, and the early labor movement all in the followIng brief quotation:

The settlement of the West was a dispersion of famliles over a great space of territory; the building up of the c1ties of the Northeast was the concentration of men and women in limited areas.... This increase of the farming area and this building up of centres of commerce and manufacture depended upon the development of transportation and this in turn created a demand for labor; but the steamboat and the rallroad made it possible to feed, house, and warm large groups of people in contracted spaces. At the same time the constantly broadening market for manufactured goods and the Increasing area from which the manufacturer could draw his supply of raw material rapldiy led to manufacturing in larger units and thereby separated the owner and manager from the working men and women. 32

Channing related his thesis to the success of W1lliam Lloyd aarrison's abolitionist activities, writing that "w1th the improvements in transportation that came so rapidly after 1825, Garrison was able to organize the new movement on a much larger and more permanent basis than had been possible in the earlier time."33 And finally, he speculated, rather profoundly for 1921, about transportational developments in this fashion:

It is an interesting thought how one invention supplants another. For a time, the cry was for roads and more roads; the Nation, the States, and private

\footnotetext{
$32_{\text {Histony, }} \mathrm{V}, \mathrm{pp} \cdot 70-71$. 33 Ib1d., p. 148.
} 
companies undertook their construction and operation usually in return for tolls that were levied on all trafflc passing over them. Then came the canals which rendered partially useless the stagecoach and the wagon, and also the atone road except for merely local purposes. In their turn the canals were hardly completed as a system when the steamboat and the ra11way took business away from them. Is it not possible that the automoblie and motor-truck with the alrplane and the electrically propelled car will one day, and perhaps a not far distant one, likewise deprive the railroad of 1ts place in the transportation system of th1s country? 34

In all falmess, however, it should also be noted that Channing put forth another thesis in this volume just as sweepIng as the one concerning transportation, and real1y did not do much else with 1t. He wrote:

The persistent and ever increasing demand for cotton fibre, the improvement of the cotton-gin, and the discovery that the short staple, green seed cotton plant throve marveliously in the uplands of South Carolina and Georgia and in the black belt to the westward, changed the whole course of economic and social existence in the South and, indeed, governed the course of history of the United States down to the year 1865. In 80 far as El1 Whitney's perfection of the cotton-gin contributed to the cultivation of the upland cotton plant on a great scale 1t was a curse to the South, to the United States, and to humanity. 35

He had earlier brought the two factors together somewhat when he wrote in the fourth volume:

The phenomenal extension of cotton culture determined the history of the Lower South and... fastened Negro slavery on that region; the application of steam to water transportation made

34 Ib1d., pp. 19-20. Just a few other pages where Channing gave attention to transportation as an important factor in one way or another are: $p p .30,33-34,77,88,99,174$.

35 IpId., p. 121 . 
possible the rapid settlement of the West in time to counteract in a męssure the growing strength

of the Slave States.36

The only way Channing changed The Perlod of Transition

from the way he had it planned when he wrote to Brett in the summer of 1918 was in the apportionment of space. The humanitarian and mechanical readjustments of the years 1815 to 1850 occupled the flrst half of the volume, rather than only the first period. The "doings" of Jackson and his successors (actually Monroe and his successors) and the material on Texas, Californla, Oregon, and the Mexican War all together occupled the second half, rather than the last two-thirds. Th1s, indeed, is the most strikingly obvious thing about volume $V$, the greater proportion of space given to non-political material as compared with the first four volumes.

Though the reader is once again bothered by Channing's fallure to make the story of some of these topics an integral part of the history of the era, there is st11l some very Interesting and worthwhlle material in the flrst half of this volume. Most of the flrst chapter was taken up w1th transportation, the Erle Canal recelving particular emphasis. Channing credited Dew1tt clinton with the construction of the canal, and sald the effects of 1ts opening were "Immediate and great." "It provided a comparatively easy and uninterrupted mode of

36 Edward Channing, A History of the United States. Volume IV: Federalists and Republicans, 1789-1815 (New York: The Macmilian Company, 1917), p. 436. 
transportation from the Hudson to Lake Erle." And, "It fac1l1tated the movements of western emigrants and provided a commerclal outlet for the surplus products of their farms," but "1ts greatest effect was to stimulate the growth of New York City."37 The rest of the chapters of the first half were devoted to "The Westward March," "The Urban Migration," "Soclal Readjustments in the First Half of the Century," "The Changing Religious Scene," "Education," and "L1terature."

The West, of course, was necessarily a major concern of Channing in th1s volume. It almost seems, though, as if he dealt with it only because it was necessary. He called the ent1re area "Transappalach1a." H1s comments on Freder1ck Jackson Turner's works at the end of "The Westward March" were largely non-committal; he d1d concede, however, that Turner's The Frontier in American History was "the best work on the subject." 38 He seriously soubted that the frontier had had such a significant democratic influence as his colleague had contended. "It is remarkable how evanescent has been the influence of these new conditions," he wrote, almost sarcastically, "for the American people is now and has been for some years among the most conservative of the nations of the earth." 39 His account showed that he had at least read Turner, however,

$$
\begin{aligned}
& 37_{\text {H1story, }}, \text { pp. 11-13. } \\
& { }^{38} \text { Ib1d., p. } 67 . \\
& { }^{39_{\text {Ib1d. }}, \text { p. } 66 .}
\end{aligned}
$$


and he sometimes wrote passages that sound like Turner himself. "The migration from the '0ld Thirteen States' on the Atlantic seaboard and from European countries to the M1ssissippl Valley is one of the marvellous phenomena of history," he sald. It "substituted clv1lization for savagery at the cost of the extinction of the original occupiers of the land, to the accompaniment of warfare, treaties, and the inevitable effects of the contacts of savagedom with the vices and diseases of c1v111zation." 40 He managed to keep transportation an integral part of the story, of course:

The obstacles to the occunation of this country [Transappalachia] had been the difficulty of reaching 1t from the Atiantic seaboard and the lack of surplus population in that section to take advantage of such means of transportation as then existed. In 1800 there were not enough people living in the orlginal states to more than scratch the surface of opportunity. Those who sought the lands over the mountalns in the earlier time were actuated mainly by the love of adventure, by the lure of the w1lderness; stern economic necessity had not as yet touched the people of the older aettled area. From 1800 to 1820, the embargo, the war, and the hard times spurred on migration; but 1 was not unt11 the financlal revulsion of 1837 and the oritical years thereafter that eastern people sought the western w1lds in great numbers. Th1s gradual strengthening of the tide of emigration from east to west synchronized with the development of the new modes of transportation.4I

Channing's description of the stages of frontier settlement was brief and simplified, but written in language worthy of the author of the frontier thesis himself:

$$
\begin{aligned}
& 40_{\text {Ib1d. }}, p \cdot 37 . \\
& { }^{4 I_{\text {Ib1d. }},} \text { pp. 39-40. }
\end{aligned}
$$


The first settlers were backwoodsmen, or fron t1ersmen, or ploneers, or pathbreakers,--they cannot be called farmers or planters because as soon as they had brought a little patch of ground into farming condition, they sold out to the next comer and moved away into the wilderness. They were temporary reversions to the hunter type; they did not belong to the agrlcultural stage. They loved solitarlness and the smell of the smoke of a nelghbor's chimney was in 1tself enough to drive them back to the wilderness road. The mother and children had as great a fondness for the life of the fringe of civilization as the father and moved willingly on and on with him. Danlel Boone is the stock representative of this type and he 1 is a very good one, because not unt11 age stiffened his limbs could he be brought to quiescent living. Next came the farming and planting ploneers following hard on the first rank of wilderness invaders. They exh1b1ted some symptoms of settled ex1stence, bullding better cabins than the half-faced camps. They cultivated the flelds for several years unt11 the ground was free from stumps, the so11 pulver1zed, and ne1ghbors appeared. Then the "Western Fever" selzed upon them and drove them once more to the wilderness... 42

In the chapter on the plantation system and the abol1tion movement, Channing gave a rather critical evaluation of the radical abolitionists, but praised the work of such moderates as John Quincy Adams and his own great-uncle, W1111am Ellery Channing, who, sa1d Channing, "trod the middle path that satisfies no one, but sometimes 18 the path of w1sdom."43 The plantation system 1tself appeared most unappealing to the twentieth century New England historian. Here are excerpts from his description:

$$
\begin{aligned}
& 42 \text { Ib1d., pp. 43-44. } \\
& 43 \text { Ib1d., p. } 170 .
\end{aligned}
$$


The life on one of these great plantations must have been monotonous in the extreme. It was one ceaseless round of looking after the slaves, keeplng them in health, seeing that they did not steal or run away, and superintending the superintendents or overseers...All in all, the troubles and vexations of plantation life must have detracted Immensely from the pleasures of existence and to this must be added the burden of debt that often hung over the owner of thousands of acres and hundreds of slaves. In fact, the great planter of the Cotton Belt had all the business cares of the prosperous Northern manufacturer or man of commerce with a multitude of petty human deta1ls thrown in. It $1 \mathrm{~s}$ by no means improbable, as one Southern wr1ter had Intimated, that the slaves were often happler than their masters. 44

In the opening paragraph of his chapter on "Soc1al Readjustments," Channing wrote that "Unt11 the War of 1812 the people of the UnIted States were occupled--apart from the necessary bread winning-with the resettlement of the pol1t1cal fabric after the separation from the Brit1sh emplre. There had been reformers and phlianthropists before $1783, "$ he continued, "but their volces had been those of Individual men and women crying in the w11derness." Channing expressed conf1dence in the efficacy of reform legislation, saying that "1t seems certain that a nation's habits can be markedly changed by legislation which, in the course of years, sets up a new standard in men's minds and consciences." And he thought the perlod under review a most productive one in this regard. With the one exception of lotteries, which Channing considered a "most demoralizing institution," he felt that "the first

$$
{ }^{44} \text { Ib1d., pp. 123-125. }
$$


fifty years of the nineteenth century saw more progress in the reconstruction of American morals than all the years that had preceded since the first settlement at Jamestown in V1rgin1a." 45 In his comments on religion, Channing was careful not to be prejud1ced in support of h1s Un1tarian ancestor W1lliam Ellery Channing. But he expressed views traditionally assoclated with that falth, which was also, of course, h1s own. He seemed to write with approval of the broadening activities of the churches:

As the years went by, the activities of the churches widened. The religlous people began to look after the affairs of the body and before long devoted so much time, strength, and resources to the founding and maintalning of schools, hospitals, and recreative organizations that the modern observer sometimes finds it difficult to discrimInate between those that may well be looked upon as religious and those that are mainly concerned with phyolcal and mental welfare. 46

He also showed a most broad-minded att1tude toward divergent rellglous bellefs:

As the century advanced change succeeded change; new doctrines, new disciplines, new modes of procedure are everywhere to be discerned. To a twentieth century historical onlooker it is oftentimes difficult to comprehend what some of these differences really were and even more difficult to understand how men were willing to sacrifice themselves and their families for what seem to have been distinctly doubtful matters or matters of small moment. But so 1t was, and however much difficulty one may have in understanding, there is no question whatsoever that the earnestness of purpose and tenacity of bellef of

\footnotetext{
${ }^{45}$ Ib1d., pp. $172,179,200$ 。 ${ }^{46}$ Ib1d., p. 209.
} 
the holders of any one of these hundred or more religlous divisions deserve the most earnest and respectful consideration. 47

He even stralned to be objective in dealing with the oftcriticlzed Mormons. For one thing, he actually read The Book of Mormon. He wrote to Brett in 1917 noting that he and his family had been speculating as to whether a book Brett had sent them was flotion or fact, and then continued:

As for me I am reading the Mormon Bible about which there 18 also much speculation. If I can write slx pages on Mormonism + continue in good odor in the First Par1sh Church + also sell coples in Salt Lake C1ty I shall have accomplished a straddle like that the Kalser wished to achleve。 48

In Channing's treatment of education, the same nostalgio note is sounded as in his American Historical Association presidential address. "The first third of the nineteenth century is usualiy regarded as the most barren in the educational h1story of English America," he wrote, "yet that was the precise tIme when the reading hab1t was the most w1despread among our people, when the writing of verse and prose was most common, and when our greatest writers were dolng the1r best work or securing their mental stimulus." If the object of education was to produce scholars, felt Channing, the educational system of that time was "singularly successful." But, he admltted, "Its Influence was not widespread." The small "ungraded

$$
47_{\text {Ib1d. . p. } 206 .}
$$
Collection.

48 Channing to Brett, August 9, 1917, Macmillan 
schools" of that day Channing consldered an 1deal educational institution if 1 t had the advantage of a "born teacher." Students in such a situation "must have been mentally stimulated and educated in the truest sense of the word,--far beyond what they can gain in the excellent graded schools and with the admirable text-books of our own time." Indeed, concluded Channing, "by 1860, the golden age of American scholarship was passed." 49

Channing had an extremely high opinion of the literary productions of the era under review; some consldered it excessively high. Channing's own grandson stated emphatically that "The fleld of American literature was definitely not the province of the scientific historian." Indeed, Channing's treatment of the subject, according to this descendent, was "somewhat queer," and contained "some very funny judgments."50 what did Channing say to deserve such criticism?

Great as were the changes in the outlook of the people of the United States that have been noted in the preceding chapters, it is in the domain of literature that the renalssance of the American mind is most noticeable. Before the Revolution there was no literature or very little that can be so accounted and the Revolutionary epoch 1tself was taken up from the literary side with the production of a series of most remarkable political papers that reach their highest point in "The Federalist." With the turn of the century

${ }^{49_{\text {History, }}} \mathrm{V}, \mathrm{pp} .242-243,271$.

50 John Channing Fuller, "Edward Channing: Essays on The Man, The Teacher, and The Writer" (Unpublished senior honors thes1s, W1111ams College, 1943), p.124. 
the production of works of fiction, poems, and essays proceeded on an ever lncreasing scale, both as to quantity and as to quality until 1 t culminated In the literary efflorescence that is assoclated w1th the names of Emerson, Hawthorne, Thoreau, and the others of the New England group. 51

He also sa1d: "In short, th1s half-century in the United States in poetry, in fiction, and in history stands apart,--1t is without an equal since the days of Shakespeare, Franc1s Bacon, and John M1lton."52 If Channing's comments were so "queer"--and they do at least seem to have differed from the views of experts--why? Perhaps part of the answer lies in the recollection of a former graduate student in English literature at Harvard that Channing "used to amuse himself by telling me I should give it up and devote myself to American H1story. He had very little interest in literary history, and loved to make gentle fun of those who d1d."53 If th1s is true, Channing should have been more cautious in his judgments on that subject. W1th so much space devoted to the non-political, Channing's account of the political hiatory of the years 1815 to 1848 was necessarliy much more compact than usual for h1m. of particular interest and importance here are his comments on the "Era of Cood Feeling," Chlef Just1ce John Marshall and the Supreme Court, the M1ssouri Compromise, the Monroe Doctrine, the election of 1828, and the Mexican War.

$51_{\text {History, }}$, p. 274 .

$52_{\text {Ib1d., p. } 305 .}$

53 Letter to the author from Kenneth B. Murdock, September $17,1966$. 
Channing added a unique note to the "Era of Good Feeling." He reallzed that the perlod was such only superflclally, but he made the consolidation of control of the federal government by the South the major development of these years. Here is the heart of his analysis:

Polltically and superflcially the ten years from 1815 to 1825 were years of calm within the boundaries of the federal government. They have often been termed the Era of Good Feeling and are usually regarded as having no interest and as being of little 1mportance. In reality they were a formative period in our political history and in our international history of the greatest interest and of the highest 1mportance. It was in that time that forces were taking shape that were to determine the history of the United States down to the year 1865. The Southerners consolidated the1r grip upon the government of the country and developed the solidarity of soclety to the southward of Mason and Dixon's line that was to become apparent to every one in 1850.54

Th1s was made possible, sald Channing, by the general high quality of Southern congressmen, which resulted from the fact that a lelsured class, devoted to pol1t1cs, had developed in the South. Business, farming, 11terature, etc., on the other hand, occupled the most able men of other sections. Thus, "One could enumerate twenty-five or fifty men in the South in this perlod whose ab1lities could not be matched by more than a dozen Northern pol1t1cians." 55

An approving tone 18 evident in Channing's treatment of the Marhsall Supreme Court. Marshall was a V1rginian, but "a Virginian of the George Washington type," wrote Channing.

\footnotetext{
54 H1story, v, p. 307 .

55Ib1d., pp. 307-308.
} 
"Like him he was not deeply versed in the minutiae of learnIng, but like hIm he had steadfastness of purpose and the power of commanding the learning of those who worked with him." For the thirty-five years he was at the head of the federal Judiclary, Marhsall remained a Federalist. "In seven leading cases spread over the twenty-one years from 1803 to 1824 Marshall and h1s colleagues announced the supremacy of the federal government over the States of the UnIon," and "the principles and the reasoning upon which these decisions were based remained and remain to this day practically the supreme law of the land. In death, Indeed, the Federalist party triumphed." 56

Channing found it easy to relate the Missour1 Compromise to his union versus particularism theme. He began by noting that it was generally supposed that the compromise postponed civil war for a generation and was therefore justiflable from the ant1-slavery point of vlew.

There $1 \mathrm{~s}$ another way of looking at 1t. Th1s attempt of the Northern politiclans and Northern abolitionists, or both, to IImit the power of the South by destroying the institution of slavery in Upper Loulslana aroused the whole slaveholding population of the South to defend their rights,--as they saw them. At the moment the South and the Southern leaders acquiesced in the settlement from a serse of the value of the Union and from a sentimental attachment to 1t. But from that moment may be dated the beginning of Southern sectionnationalism. It developed slowly at first, but by 1825 it threw off disguise in South Carolina and by 1830 had acquired considerable solidarity, although

${ }^{56}$ Ib1d., pp. 308-310. 
not enough to bring the other slaveholding states to the side of South Carolina. In reality, therefore, the Missour1 Compromise of 1820 marked the ending of one epoch in our history and the beginning of another. 57

Later, he made the point still more forcefully. The compromise "marked the end of the first chapter in the history of nationalism," he wrote. "From that time for forty years, the whole spirit of our development was towards dualism,--for the Missouri Compromise practically marked the division of the country into two groups, having distinctly different economic interests." 58 Channing's evaluation of the Monroe Doctrine takes the form of an evaluation of John Quincy Adams as Secretary of State:

Adams was not a lovable man nor a companionable man and he had eccentricities of temper and awkwardnesses of action that concealed his real capacities and aroused enmities where none need have existed. But very few men have ever controlled the forelgn affairs of a country in an exceedingly critical time who possessed the power of the younger Adams to appraise a difficult situation and especially to deal with it with a courage and a tenac1ty almost unsurpassed. In friendly union with Monroe's cautionsness and the almost chlldilke acumen of the vulnerable Jefferson and Madison, the United States was carried triumphantly through. 59

"The election of 1828 marked the breaking down of the old system and the coming into power of the democracy of the next thirty years that was ushered in by the triumphant election of Andrew Jackson to the presidency,"60 wrote Channing.

57 Ip1d., pp. 328-329.

58 Ib1d., p. 405.

$59_{\text {Ib1d., p. } 330 .}$

60

Ib1d., p. 365. 
Not1ce that he did not say "frontier" democracy; indeed, he took 1ssue with Frederick Jackson Turner's interpretation of that election as a victory for the forces of frontier democracy. The campaign 1tself Channing properly considered "one of the most woful in our annals," with 1ts unwarranted attacks on Henry Clay and John QuIncy Adams; he was careful to point out that Adams himself engaged in no such practices. 61 Here is the heart of Channing's analysis of the election results:

When the votes were counted, it appeared that one hundred and seventy-elght electoral votes had been cast for Andrew Jackson of Tennessee and only elghty-three for John Quincy Adams of Massachusetts. This was halled by the Jackson men as a great popular triumph and 1 t did mark the beginning of a new era in our history. None the less, it is worth while to analyze the figures a bit before acceding to this or any other assertion....Jackson was really chosen to the presldency by the solld South, as was quite proper as he was a Southern man, a slaveholder, and a cotton grower. At the same time, he could not have recelved a majorlty of the electoral votes, even adding the twenty-four electoral votes of the Western States to h1s Southern votes, without the ald of Pennsylvania and New York.... Indeed, however one manipulates the figures, it would seem that Jackson was ralsed to the presldency by the overrepresentation of the South due to the federal ratio combined with the employment of most unjustifiable methods by h1s partisans in Pennsylvania and in New York. On the whole, possibly it was more honorable to have been defeated in 1828 than to have been elected.62

Channing probably even regretted that he had conceded earlier, in volume IV, that Jackson "possessed the courage and conf1dence of a man of the frontier" !53

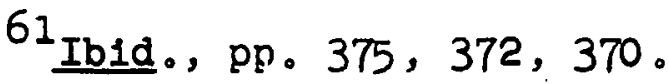
62 Ib1d。, pp. 375-376。

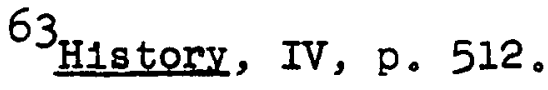


Channing had some trouble at times making Jackson and his adminlstration sound so completely southern in nature. He thought the real interest of Jackson's adminiatration lay "In the relation between the federal government and the growIng power of Southern sectionalism, as shown in the nullification episode and the rising spirit of capitalistic industrialism In the North as exemplifled in the bank struggle." "In the upshot," Channing concluded, "Southern 1deas triumphed, although nullification and secession were laid at rest for a generation." 64 In another place he wrote of Jackson: "To him the Union was sacred. He was a Statesl-rights man, like most other Southerners, but that dogma should never be used to justify action derogatory to the continuance of the Union." 65 It seems that Channing could have made his interpretation more credible by simply admltting that Jackson was, after all, a mixture of a Southerner and a Westerner, explained at least in part by the fact that he was from the nationalistic frontier area of the Southern slave state of Tennessee. Interestingly, Channing was quite willing to attest to the accomplishments of Jackson's adminlatration. He discounted the 1dea that Jackson was a radical, concluding that he was "distinctly a conservative and used the powers of his high office to restrain rather than to exc1te." And Channing

64

H1story, V, p. 402 . 65 Ib1d.., p. 423. 
contended that "Jackson's administration was successful beyond dispute." He even played down the ev1l effects of the spo1ls system. "It may be sa1d that the introduction of the 'spoils system' should not be regarded as a cause of satisfaction, and 1t should not," wrote Channing, "but the change from the old colonial system of permanent official tenure to the more democratic mode of political rotation in the public offices was inevitable, and Jackson may falrly be sald to have minimized the blow." 66

Channing's views of Jacksonian Democracy then, do not conform to any clearly-constituted school of thought on the subject, but were largely his own. By his willingness to recognize Jackson's contributions, he broke with the patrician approach of such writers as James Parton which prevalied through most of the nineteenth century. On the other hand, h1s emphas1s on the southern nature of Jacksonianism made it clear that he did not accept all the views of the Progressive historians on the period elther, for Turner's emphasis on western democracy was a vital part of that approach.

$$
66 \text { Ib1d. }, \mathrm{pp} .378,401-402 \text {. }
$$

Channing's view on three other things are worthy of brief notice.: He was critical of John $C$. Calhoun and his role in the nuliffication crisis, concluding that "political considerations and not convictions" caused him to behave as he did. (p. 420) Channing largely absolved Jackson of blame for the Panic of 1837 and went rather far afleld in his speculation that "the forces of nature" may have been responsible since the panic "synchronized with a maxima of sun spots." (pp. 456-457) Finally, Channing was critical of all involved in the presidential election campaign of 1840, which he saw as one "of 'Hurrah!' and unreason that has never been paralleled in the United States." (p. 463) 
Channing's 1nterpretation of the Mexican War sounded at times 11ke President James K. Polk's war message. He prajsed the first American colonizers of Texas as "hardworking, dod-fearing men and women of the very beat type for so arduous an enterpriso." He admired Santa Anna romewhat, but cons1dered "the great mass of the human material that he had to work with...helplesely 1nefflolent and hopelessly oorrupt." He thought 1t "easy to see" why the Texans revolted againat Mexico, and emphatioajly otated that the Mexican people ware "hopeleasly inept" in the art of government. 67

Channing's comments on the general background for the war were completely one-sided:

It was the destiny of the United states to extend to the Pacific and as far south as the arid portions of Mex100. California, New Mexico, Texes, and Oregon in 1ta old geographical aense were al1 practically unut111zed by man in 1835. Of course, it cannot be vald that the people of the United States had any moral right to take over lands that had been praot1cally unused by another peoples but $1 t$ must be said that the moral argument for the retention of these aplendld lands by a people who did not and could not convert them to the benefit of humanity re1ses a trong presumption in favor of their acquisition by those who could make, and, a a matter of fact, have made, a good use of them. The United States was ready to pay Mexico an adequate Bum for the1r transfer. For years, there had been a continual diplomatio wrangling over the refusal of the Mexioans to treat Amerioan merchants with fairness. They encouraged them to start enterprises on Mexican so11 and then refused them all facilities for so doing. In this way and in other ways, pecunlary claims by

67

In1d., pp. 520, 592, 522, 524. 
American c1tizens aga1nst Mexico arose. Allowance must be made for the disorganized political cond1tion of the Mexican people. Their governments lacked stab111ty and any concession to an outside power was the slgnal for a new revolution. Mexican politicians, therefore, were afraid to comply with the plain dictates of Justice. Recognizing the1r weakness and helplessness, the Un1ted States ylelded to the verge of 1gnominy. At length, in 1839, a treaty was signed providing for the arbitration of the American cla1ms. After long delays, Mexico was adjudged to pay certain sums of money and as her coffers were in the usual depleted condition, time was given for making these payments by instalments. Mexico pald one or two of them and then paid no more and further negotiations were entered into. Then, also, American cltizens, who had no call to go into Mexican territory, except for the pursuit of gain, mere curlosity, or love of adventure, found themselves in Mexican prisons. Some of them were Inhumanly treated. The United States protested, but recelved scant consideration at the hands of the Mexican authorlties. The fact was that the ruling classes of Mexico had a feeling of contempt for the people of the United States... 68

If anything, Channing justified the American position

st1Il more completely in h1s coverage of the 1mmediate background for war:

In the summer of 1845, General Zachary Taylor was ordered to the Texan boundary. He was instruoted to occupy a position "on or near the R1o Grande" as soon as the Texans had voted for annexat1on. Orders were also sent to Commodore Sloat, commanding the American naval force in the Pacific, to selae Cal1fornia in case of a declaration of war. In view of the probab1lity of Mexican attack on Texas while the consideration of the annexation plan was proceeding, the strengthening of the American army in Loulaiana was perfectly justiflable, if the annexation of Texas was. As the independence of the Texas Repubilc had been recognized by Great Britain, France, and the United States for elght years or more, and as the Texans had been governing themselves all that time

68 Ib1d., pp. 550-551。 stated that Texas, New Mexico, nomlcally to the UnIted States
In another place Channing had and California belonged ecoanyway. (p.525) 
without any adequate attempt on the part of Mexico to reconquer her lost province, the rightfulness of annexation would seem to be beyond the line of argument. As to California and New Mexico, which lay between that province and Texas, if Mexico made war on the Unlted States on account of this perfectly justiflable annexation, then those provinces might be considered in the light of an indemnity for the expenditure which Mex1co would force upon the Un1ted States, and in that point of view the selzure of California and New Mexico would be right and proper. 69

Channing completely wh1te-washed Polk of any blame. He thought the president had "suffered severely at the hands of contemporarles and historlans." Polk "possessed a strong w11l and an inflexible determination to do the right thing as he saw 1t," "In every crisis of his administration, 1t was his hand that gulded events," and he simply carrled out "'the w11l of the people' as expressed in his own election." 70

Continuing through Channing's account of the war, the present-day reader can only be appalled at some of his statements. The general picture which emerges is that patient, peace-1oving, superior Americans were finally provoked into a war which they quickly won because of the righteousness of their cause and the inferlority of their enemy.71 One can only wish that Channing had been more objective, and note the Influence on h1s views of the notorlous two-volume work, The

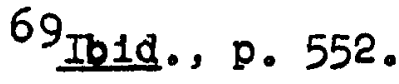

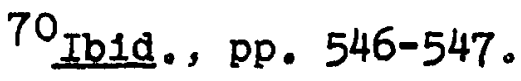

${ }^{71}$ Statements which heip give such a picture abound. See, in addition to those already quoted, Ibid., pp. 554, 558, 562 , 580-581, 589, 612. 
War with Mex1co, by Justin H. Smith, which had appeared in 1919.72

Channing concluded The Perlod of Transition with h1s usual combination summary and lead-in to the next volume:

In the third of the century described in the preceding pages, the American people threw off the social conditions of colonial days. They kept their old forms of government, but altered the sp1rit of adminlstering them in the direction of democracy. They crossed the Appalachiams in great numbers into the valley of the Miss1ssippl and over that river into the lands that they had acquired from France. "Manifest destiny" urged them on to the acquisition of Florida, to the regaining of Texas on the South, and to the possession of the lands westward from the orest of the Rookles to the shores of the Pac1f10 ocean. It remained for the future to show what would be the effect of these great changes in soolety and these immense accessions of territory. Would the Republic remain one united country, or would it be divided according to the social and economio desires of the Inhabitants of the severgl sections into which it was geograph10a11y div1ded? 73

Federal1sta and Republicant recelved one generally critical review, the first such the Oreat Work had ourfered; three of the five reviews found of The pendod of Iransition were critical; one was non-commlttal, and only one gave an over-a.11 impression of pra1se for the work. Perhaps Channing had hired "somebody to pitoh into yours truly," as he had once suggested to Brett they should do? 74

72 Channing acknowledsed hts relianoe on Smt1h. "Sm1th's research was so profound and his judgment guneraliy so just that one can place peouliar relianoe on h1s statements, "wrote Channing. "At the game time, 11ke al1 h18torioal students, he has his prejudices." (Ibid., p. 615) If only Channing had realized how farmeaching those prejud10es were, and the effect they would have on his own work!

73 Ib1d., p. 614

74 Channing to Brett, October 16, 1917, Macmillan Collection. 
Actually, the figures are slightly m1sleading, because two of the critical reviews were by the same person, Charles A. Beard. One appeared in the Freeman, the other in the New Republ1c. In the latter, Beard expressed the view that Channing told the same old story, with "no revelations, no strikIng divergences from accepted views, no new interpretations." The major difference he noted between this and Channing's earlier volumes was the emphas1s, with more than one-half of volume $\mathrm{V}$ dealing with non-political material. Beard, of course, had to get in his economic blow:

Economic affalrs w1ll project themselves rudely into politics. Tariffs, banks, and internal Improvements will burst into the pages of the Congressional alobe and the historian must take account of them, but American writers look upon them as they do upon bad boys who disturb an otherwise peaceful Sunday school.75

75 Charles A. Beard, "The Solemn Muse," New Republis, XXIX (January 4, 1922), p. 161. Beard was the master of the tongue-1n-cheek. Note these add1tional comments; "Professor Channing comes on down the years in full regalis and with solemn mien, his fixed eyes betraying not a twinkle and bis atern v1sage not a wrinkle. Amerioan history w1thout laughter and without tears! Nowhere in these massive six hundred pages is there any departure from the canons of the American historical gu1ld. The offerings to C110 may be as rollioking as Swift's Tale of a Tub, as sober as. Hallam's mag1sterial volumes, or as bolsterous as the Communist Manifesto, but Professor Channing reveals no suspicion of th1 mysterlous fact.... In style and form and language apt he addrenses the members of the brotherhood and they p1.11 answer him approvingly. Some who have the1r doubts, as they look upon the frean water. flowing by the 1r college doors, may remember that a profensorinip at Harvard 1s the academ 10 kingdom of heaven for 211 those who labor with rod and stylus. The editor of AfR, mindful of time and o1roumstance, w11l not 1gnore as orit10 what he: know as a politioal animal. The laurel of renpeotiblilty w111 be la1d upon this volume as $1 t$ was upon 1 ts four predecessors. It is aitogether fitting." (pp. 160-161) 


\section{0}

Beard concluded that Channing left unanswered all the 1mpor tant questions of the period.

Beard made his economic point st1li more forcefully in his review in the Freeman. "Why does Professor Channing.. tell us something (not much) about John Marshall's epochmaking decisions, but keep sllence on John Marshall's economics and pol1t1os?" querled Beard. "H1s answer would be more interesting and important than his book."76

The non-committal review appeared in the Bookl1st; the pralseful one appeared in the American H1storical Rey1ew. 77 Dixon Ryan Fox was the reviewer who pra1sed Channing's work. He thought The Period of Transition 1tself represented a per1od of transition in the writing of American history with 1 is extensive attention to the non political. He praised speciflcally Channing's falrness in dealing with sectional quest1ons, his extensive use of sources, h1s style, and the charts and maps in the volume. And he conoluded:

The reader carries away the impression of a wise and careful scholar with whom no traditional judgment can pass without investigation and to whom nothing that $1 \mathrm{~s}$ American 1s fore1gn... If in each generation some single veteran scholar should take stock of what $1 \mathrm{~s}$ going forward in the historical study of the United States, Professor Channing shoyld be warmly thanked for his service to our own.78

76 Charles A. Beard, "The Art of History-Writ1ng," Freeman, (December 21, 1921), p. 356 .

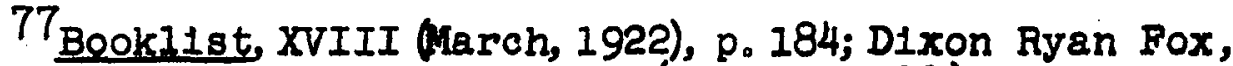
American H1stor1cal Review, XXVII (Apri1, 1922), pp. 590592. Perhaps Beard was right!

78 Fox, p. 592. Fox, as co-editor of the ploneering 
Paul $H$. Buck stated it milaly when he sald that Chan ning's fifth volume "upset the West。"79 That the west got even more than upset by the hork is well attested by the review by Clarence $W$. Alvord which appeared in the M1ssissippl Valley Historlcal Review. It was the most critical review by far that an Edward Channing book ever recelved; it was probably one of the strongest ever to appear in the Review. No wonder 1t "was the one review that 'got in Edward Channing's ha1r!" 80

Alvord claimed his first thought upon reading Channing's opening lines on war, transportation, and the Turner thesis, was, "So this is the effect of the world war on the historlcal mind. I was expecting 1t。" The b1g problem, as Alvord saw 1t, was, of course, Channing's treatment of the West. Alvord even resented Channing's use of the term Transappalachla, and countered it by referring to the region as Cisappalachia throughout his review. "Although the book proves that Mr。 Channing has discovered the West, he has not learned to appreclate the signiflcance of events in 'Clsappalachia' in the development of the Unlted States," contended Alvord. "These events possess in his eyes an antiquarian interest or an 11lustrative value, but they have not perverted his eastern polnt of view." One "vital factor in the development of the west,"

H1story of Amerlcan Life series, would have been particularly pleased to see Channing's attention to non-political history. 79 Intervlew with Paul H. Buck, June 9, 1967, Cambridge, Massachusetts。

${ }^{80}$ Fuller, "Edward Channing," p. 122. 
the Indians, "Is entirely omitted from this volume," Alvord continued. He complained of the "very thin narrative" of the political history of the era; he felt Channing's arguments on the election of 1828 simply missed the point; and he saw as "particularly interesting" about Channing's transportation thesis "the humorous aspects of the subject"! 81 Finally, even when Alvord tried to sound apologetic for the bitter tone of his review, he falled:

Since this review is written for western men and women, its emphasis has lain naturally on Mr. Channing's treatment of events in which Cisappalachians are interested, and the reviewer may have appeared somewhat unfair to a writer of such pronounced eastern affiliations as is Mr. Channing, even though he is writing a History of the United States.

Fortunately, Channing's sixth volume fared better.

${ }^{81}$ Clarence W. Alvord, Mississippi Vallev Historical Review, VIII (March, 1922), pp. 377-380.

82 Ib1d., p. 380. 
THE WAR FOR SOUTHERN INDEPENDENCE,

AND THE END OF THE GREAT WORK

I hope the American Historical Revlew will thinkg [sic] it [volume VI] "Just the thing"; But I am shivering In my shoes, for the Grand Army of the Republic and the Daughters of the Confederacy w1II join arms and march on Widener 417 and throw me out of the window. Never mind! Let them come! It has been great fun writing the book and I hope that at least one person w1ll have some 1deas as to the labor it has cost. 1

A former student of Edward Channing recalis that his

"dedication toward completing his history was complete and intense."

He was working on volume 5 when I was h1s student for the doctorate. Naturally his students worked on thesls subjects wh1ch would serve Channing's current work. Th1s sounds self1sh. It wasn't. It gave the student the sense of being a fellow craftsman. Channing was more apt to read to a student something he had written than to read something the student had written. In the role of a fellow scholar Channing showed how he and h1s longt1me secretary, Miss Eva Moore, achleved accuracy of statement and citation--a valuable lesson.2

With help from students and an almost unbellevable amount of effort on his own part, Channing was able to publish the Pulitzer Prize-winning sixth volume of his Great Work, The

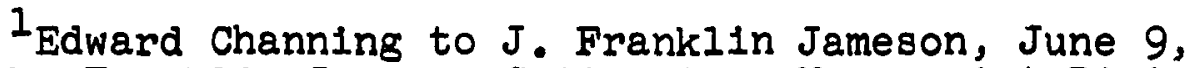
1924, John Franklin Jameson Collection, Manuscript Division, Library of Congress, Washington, D. C. 1966.

${ }^{2}$ Letter to the author from Edward C. K1rkland, July 18, 
War for Southern Independence, in June, 1925. The extent of h1s own labors becomes ebundantiy evident in his correspondence. He wrote to President A. Lawrence Lowell from R1chmond, Virginia, on January 7,1922 , desortbing h1s aotivities as follows: "At th1s place I have exhausted the Confederate Museum + the State Library--very profitably--and tomorrow tackle the Archlves. There is very little general matter there + we shall go to Washington Wednesday or so--1f we can find quarters to stay several weeks and work in the manuscripts." In July of the same year Channing wrote to George P. Brett that he was "blazing away on Vol. VI."3

Channing had problems again before he finlshed this volume, however. His eyes, a problem even in his youth, began to bother him significantly. "The truth of the matter is that my eyes have been acting rather queerly and just at present the future seems to be a little doubtful," he wrote to Brett on November 6, 1922. "If my eyes do not oome back in fighting trim, we shall probably have to atop the whole thing with volume $81 x, "$ he continued. "I have got so far in the researoh on that volume that I could probably finiah [810] 1t. But just at present, I do not feel like saying anything more." He tried

3.Edward Channing to A. Lawrence Lowe11, January 7 , 1922, A. Lewrence Lowell Papers, Harvard UnIversity Arohives, Cambridge, Massachusetts; Edward Channing to Ceorge P. Brett [President, Macmilian Company], July 9, 1922, Edward Channing F1le, Maomilian Authors Collection, New York Publ10 Library. 
to conclude optimisticaliy. "Th1s may be a passing whirl," he sald, "and my eye doctor may be able to flx things up." 4 Channing visited his doctor, and the situation did 1mprove. He wrote again to Brett on December 14:

I have returned from Chattanooga, restored in body and in mind,--at least I hope so. I think the eye man was right, that the trouble with me was fatigue, the result of trying to write volume v1. As a matter of fact I wrote some of 1 t in my mind at Chattanooga and more at Washington. I am working one hour less a day and am trying to make more use of my secretary's eyes. Also, I am cutting out newspapers and varlous other luxurles. How long this freedom from eye strain w1ll last, I cannot say, and how much difference in time it will make in the appearance of volume $v 1$. cannot say.5

Channing wrote to J. Franklin Jameson in May, 1923, that "The book [heavily underlined in ink], vol. v1, is worming its way along, after the manner of such things. At the present moment, I am lost in wonder as to why we ever 'fit' in 1861 and why having begun, we ever stopped." 6 By September of that year he almost had the solution, for he optimistically predicted to Brett that the volume would be ready by February, 1925. He continued:

I know, of course, from a publisher's standpoint, this seems to be an absurdly slow rate of progress, but you must remember that this is the "standard History of the United States" and is to remain so for fifty years. So it is better to go slowly, even

\footnotetext{
${ }^{4}$ Channing to Brett, November 6, 1922, Macmilian Collection.

${ }^{5}$ Ib1d., December 14, 1922.

${ }^{6}$ Channing to Jameson, May 3, 1923, Jameson Collection.
} 


\section{6}

If one sacrifices those returns that w11l probably come when you have the whole set at your disposal and the royalties go to my helrs!?

On December 28, 1923, Channing informed Brett that he was through w1th the first draft of the volume, and on June 9 of the following year that he was "preparing for the final bout." III fortune struck again, however, The mother of Channing's secretary became 111 and died. Channing told Brett of this in a letter of December 29, 1924. The misfortune had placed them behind schedule a couple of months, he sald, but he tried to console Brett by assuring him that the volume would "have a good sale--better than any of the others--and w11l help the sales of all of them." 8

By March, 1925, h1s manuscript was apparently in the hands of the publisher, for he wrote to Brett:

The sooner 1t gets out the better. I am informed that if teachers get it in May, they will be in a position to compell hundreds or thousands or hundreds of thousands of students, throughout this broad land of ours, to purchase the book or, at all events, to read 1 t.9

7 Channing to Brett, September 26, 1923, Macmillan Collection.

8Ib1d., December 28, 1923, June 9 and December 29, 1924. Channing apparently malntalned his habit of 1solating himself all through this per1od. He must have been speaking of the meeting of the American Historical Association when he wrote to Jameson in June, 1924: "I rejolce to recelve your annual letter and Invitation and if I do not join the brethren at Branford, it is not because I do not love my brothers and wish to commune with them, it is because I am mortgaged to volume v1 of a 'History of the United States'." (channing to Jameson, June 9, 1924, Jameson Collection.) Collection.

${ }^{9}$ Channing to Brett, March 4, 1925, Macmilian 
Channing was very concerned when Brett suggested that the manuscript might be too 1ong. "I fully belleve it to be the best thing I have ever done and should be very sorry to injure 1t by hacking," he wrote. The letter was typed, but Channing added a phrase with his pen: "even if you have to charge five dollars for 1t." 10

The War for Southern Independence did not quite make Channing's May publication deadine, and whether hundreds of thousands of students were forced by the 1 teachers to read $1 t$ that fall is not known. But Channing may very well have been right in considering the volume the best thing he had ever done; It was, certalnly, one of his finest works. His grandson considered volumes III and VI the two outstanding volumes of the series. More Importantly, Paul H。Buck in 1967 stili considered volume VI "as good as we have" on the subject. ${ }^{11}$ It was certainly well recelved. At least fourteen revelws of the volume appeared in print, a greater number than accorded to any single volume of the Great Work thus far. They had their criticisms, of course, but the general impression is a very favorable one. The volume also recelved the $\$ 2,000$ Pul1tzer Prize as the outstanding book on United States history published in the year 1925.

\section{${ }^{10}$ Ib1d., March 17, 1925.}

${ }^{11}$ John Channing Fuller, "Edward Channing: Essays on The Man, The Teacher, and The Writer" (Unpub11shed sen1or honors thesis, W1lliams College, 1943), p。126; Interview w1th Paul H. Buck, June 9, 1967, Cambridge, Massachusetts . 
Channing began the volume with a chapter ent1tled "A Divided Country." Though he did not point 1t out h1mself, his description of the situation as of 1850 sounds much like his 1dea that there were two nations within the Brit1sh emplre by 1760 :

By the middle of the century, two distinct social organizations had developed within the United States, the one in the South and the other in the North. Southern soclety was based on the production of staple agricultural crops by slave labor. Northern soclety was bottomed on varied employments--agricultural, mechanical, and commercial-all carried on under the wage system. Two such divergent forms of soclety could not continue Indefinitely to live side by side within the walls of so loosely constructed a system as that of the United States under the Constitution. One or the other of these socleties must perish, or both must secure complete equality ...or the two socletles must separate absolutely and live each by 1 tself under 1ts own government.12

In his further analysis of the situation, it must be noted that Channing was not entirely free from an anti-southern bias. After quoting a statement made by Langdon Cheves of South Carolina before the Nashville Convention of 1850 to the effect that the South had to secede from the Union as the only efficlent protection against "aggravated wrongs" at the hands of the federal government, Channing commented: "The twent1eth century historical student finds it difficult to understand how the slaveholders and the slaveholding States could by any possibllity have endured aggravated wrongs at the hands of the

12 Edward Channing, A History of the United States. Volume VI: The War for Southern Independence (New York: The Macmilian Company, 1925), pp. 3-4. 
Federal government, for the Southerners themselves had held that government within their control for at least fifty of the sixty years of 1ts 11fe." He proceeded to show how the South, or Southerners, had controlied the Presidency, Congress, and the Supreme Court for the major portion of the 1789-1850 per1od. "Not only had the South possessed control of the Federal government," conoluded Channing, "1t had constantly and consistently used this power for 1ts own protection."13 But this situation was coming to an end:

It was possible that slavery might have remained a living institution within the limits of the cottongrowing States for many, many decades. Moreover, had the Southern leaders been men of great widsom and foresight, peaceable secession might have been achleved in 1850. As it was, instead of ameliorating the slave-labor system and confining it to the Cotton States or pushing on separation while 1 t was feasible, the Southerners sought to combat the freewage-system soclety of the North by enlarging the area of slave territory and securing the right to carry their slaves with them, without danger of 10s8, into every part of the country. Th1s attempt to secure the recognition by law of their peculiar institution was against the whole economic, soclal; and moral sentiment of the times, not merely in the Northern United States, but throughout the greater part of the civilized world.....It was perfectly plain, even in 1850, that in every year the North was Increasing in man power and in material resources as compared with the South. Inevitably this superlority would sooner or later be transiated into elements of political power and the South would lose the grip on the government of the United States that 1t had enjoyed since 1789.14

${ }^{13}$ Ib1d., pp. 1-2.

14 Ib1d., pp. 4-5. 
Channing even condemned Southerners somewhat for not seelng what was happening in the 1850-1860 decade, 1 ese, their falling to match the North in population, wealth, and. the like. They "remained on the1r plantations, closed the1r eyes, and contented themselves with counting the wealth of prominent Southern persons and families." "Of course, it is men and 1deals and not money that make a nation and give the direction in which progress shall move," Channing admitted. "But when one thinks of taking a radical and far-reaching course of action, it is well to look the cold facts of numbers of men and mililons of dollars squarely in the face. The Southern leaders were elther unwliling or incapable of dolng this very thing."15

Beyond this general analysis, however, Channing was remarkably free from blas for the perlod in which he was writ1ng, and he showed on occaston a great deal of 1ns1ght. He painted a meaningful, if slightly overdrawn, portralt of the Southern planter, who had developed "a distinct physique, a distinctive speech, and a characteristic mode of thought":

- The typlcal Southern plantation white man was of good helght, with a lean body, a thin face, and a charaoter1stic far-off look in his eyes. As he stood, he held his hands a little in front of the median line and his shoulders ordinarily were drawn a I1ttle forward. He had a soft sub-tropical intonation and a "plantation patols" that had come to him in part at least from chlidhood assoclation with the ever-falthful colored "mammy" and his playmates, the "Ilttle niggers." His dialect was in a way as marked

${ }^{15}$ Ib1d., pp. 35-36. 
as that of the New England farmer or of the Northwestern settler in the days before efficlent transportation had broken down barriers of speech as well as of occupation. The Southerner was very self-centered and 1ntent on his own affairs,--upon the condition of the crops, the price of cotton, or the run of sugar. For half a century and more the Federal capital had been the rallying point of the more influential political leaders of the South; the State cap1tals had served the lesser politiclans, and the county elections had been the principal meeting ground of local leaders and the voters. Apart from the crops and from litigation over lands and debts, politics was the chlef mental excitation of the Southern white, rich or poor. Living in close contact with an alien race, he naturaliy and necessarliy had self-protection always in the very front of his mind. At any moment of the day or of night, he might be required to strike at once and to strike hard to save hIs own $11 f e$ and to protect his wife and his children. He possessed a militant nature and brooked no insult from any one--Southerner or Northerner. If he felt aggrieved, he sent the other man a challenge, and $1 f$ the other man refused to flght, he knocked him down or horse-whipped him at the first opportunity...The southern planters IIved contented and happy lives surrounded by a white peasantry and a black servile laboring class. They belleved themselves to be the chosen of the earth and as superior to the fanatics, business men, laborers, to "the mongrels and hirelings" of the North as one set of men could be superior to another. To their minds it would be a "dishonor" to be governed by such as these. 16

Channing was able to remain quite detached from the

\section{institution of slavery:}

In any attempt to appraise the condition of negroes in slavery in the epoch under review, it must be, in part at least, governed by the fact that each one of them in the years of his or her greatest activity and at this period in our history was worth from one thousand to two thousand dollars. No planter could have worked his slaves beyond the1r capacities or Inflicted labor-destroying punishments upon them without serious loss to himself. In point of fact,

\section{6 \\ Ib1d., pp. 10-12。}


If the crops were poor, if provisions were hard to get, it was the white family in the house that suffered, and not the negroes in the cabins; for whatever else might happen the bodily capacity of the slaves must be maintalned for the next crop season. Also it is true that for a brief period in each year, at cotton-plcking time and at the sugar-making season, labor was severe in the fleld and in the sugar house, but $1 \mathrm{t}$ may safely be sald that $1 \mathrm{t}$ was never more severe than 1t was in the iron-making establishments of the North or, at times, on the farms of the Free states. Southern writers and speakers, one after another, tell us that one could see more wretchedness in a day's walk on the streets of New York than one could witness on a tour through the South,--and the slave when old and Infirm was cared for on the plantation and not turned adrift to beg or to starve. 17

As evidence for the last portion of these statements, Channing noted the usual facts of lack of slave support for John Brown and slave quietude during the war years. Channing did admit that there were valid objections to the slavery system. He recounted a story attributed to Andrew Carnegle which he felt exhibited "the essence of the objection to the system":

An Oh10 judge is represented as interrogating a fugitive slave and upon the colored man telling him that he had plenty of food, good shelter, plenty of olothes, and a good master and that he did not have to work very hard, the white man suddenly asked, why if he had all these things did he run away, and the fugltive replied that the place he had left was open, that the Judge could do down and take 1 t,,- and resumed his :IIne of march for Canada. 18

"Iike everything else," concluded Channing, "the goodness or the badness of the system depended upon the point of view."

$$
\begin{aligned}
& 17_{\text {Ib1d., pp. 18-19. }} \\
& 18_{\text {Ib1d., p. } 15 .}
\end{aligned}
$$


Channing addressed himself briefly to the oft-disputed question of the profitability of slavery, concluding that before the great increase in slave prices after 1850, "It was probably true that on the best conducted plantations the slave gang was the cheapest and most efficlent agricultural labor in the world in terms of the crop produced." Even after 1850, he concluded, "more slaves not more land was the need of the South."19

When he turned from the institution of slavery to the Negro himself, Channing was not quite so successful in remain1ng objective. At least, according to the standards of today he was not; but we should be even more careful than he was to Judge by the standards of the time under consideration rather than those of our own. Here are parts of his comments on the Negro:

All treatments of Southern 11 fe by Northern writers gave an ent1rely false assessment of the weaknesses and the strengths of the slave system. They uniformly applied white standards to black I1fe without any comprehension of the actualities of negrold, racial development. This was partly due to the inability of every man and woman to see good in unacoustomed ways of living of other persons; but 1t was more especlally due to the fact that in those days knowledge of negrold Institutlons and conceptions of negrold 1deals were very vague and extremely inaccurate. Since 1890, many competent explorers have visited Central Africa and the Congo and have set down in print the results of their observations and of their communings.w1th the natives. Reading these many accounts, welghing them, and trying to draw judgment from them, it appears that it is about as hard for the Ethiop to

\footnotetext{
${ }^{19}{ }_{\text {Ib1d. }}, p p .23,16$ 。
} 


\section{4}

change h1s institutional and racial conceptions as it 1 s for him to alter the color of his skin. Both his institutions and his skin are matters of heredity. They have come down from a very remote past and are, even today, being handed on unchanged to future generations。 20

"In his pure condition, undiluted by white or yellow blood, the negro is essentially a communist and a fatalist," Channing's analysis continued. Something further of Channing's view of the Negro is expressed in a letter he wrote to Jameson in 1916. It was a recommendation for Carter $G$. Woodson, the wel1-known Negro historian. "Woodson wrote h1s thesis under my guidance," Channing began.

He Impressed me as a very good man. He was more assertive than most of his race and was desirous of dolng thorough work. He is accurate in deta11s, but like most of us, white as well as black, sometimes overlooks an authority. I think you can trust him as fully as you can any colored man; but he nas, of course, the defects of h1s color.21

After a fifth volume in which approximately half the space was devoted to non-political materlal, Channing reverted to an almost completely political narrative for his sixth volume. In several ways, this was logical. For one thing, the political events centering around the North-South diver.. gence over slavery and other matters certainly const1tute the dominant theme in the history of the 1848-1865 per1od. For another, there was a good deal of overlap at both ends in

$$
{ }^{20} \text { Ib1d., pp. 19-20。 }
$$
Collection.

${ }^{21}$ Channing to Jameson, June 1, 1816, [sic] Jameson 
Channing's social and cultural chapters in the first half of volume V--in other words, they covered, to a certain extent, the ent1re 1789-1865 period. Finally, 1t was not only logical but also beneficlal that Channing's sixth and final volume was predominantly political in nature. He wrote political history better, and, more importantly, he wrote better when he had a central theme. Here, for the first time in the entire set, actually, he had one for an entire volume. And not only did he have a central theme, but 1 t was also the culmination of $h$ is thesis from the preface to the Great Work, 1.e., that the most slgniflcant single development in United States history was the victory of the forces of union over those of particularism. Channing did not take the opportunity to elaborate spec1fically on that thes 1s here, but 1t $1 \mathrm{~s}$ an obvious under-current throughout.

One of the few places in the volume where Channing stepped aside from this central theme was in the second chapter, on "Cal1forn1a, Oregon, and Japan." But even th1s material he managed, after a fashion, to relate to the slavery cris1s in his end-of-chapter summary:

All in all, what with California gold, Oregon wheat and salmon, the opening of Japan, the growth of far eastern trade, and the looking into the Caribbean and the countries of Central America...these years and these achlevements betokened a coming change in the mental attitude of the American people that seems always to portend revolution. In ali this change and coming revolution, the people who gained were the merchants and ship owners of the North. Almost alone In the advanoing modern world, the South stood st11l. As it was in 1830 so it was in 1850 and so $1 t$ was quite likely to be in 1860. Southern forward-Iooking 
men felt a certain nervousness which they could not conceal, but which they tried to hide under a recounting of their invincible position in the world of commerce. They possessed, James A. Seddon declared, a monopoly of the production of cotton flbre and if they refused to plant their cotton r1elds for one, for two, or for three years, the manufacturing nations of Burope and the Northern States of the Union would see the sources of the1r own prosperity dry up; the Northern lords of the loom, the merchant princes, the weal thy mechanics, and the thriving laborers would feel the gloom of a common cloud. Northern ships would rot at the wharves, factories crumble stone by stone, clties dwindle to half their size, and all th1s would happen unless the Northern men in Congress would accede to Southern demands for the extension of slavery and slave territory.22

When Ceneral Zachary Taylor was Inaugurated Pres1dent on March 4, 1849, "he found himself face to face w1th diffioulties fully as great as those that had confronted any prev1ous President since the days of Washington," wrote Channing. "Every week, every month, almost every day," he continued, "the mutterings of the political storm that was sweeping up Irom the South became more and more audible unt11, by the m1ddle of 1849, the1r 1mport could by no possib111ty be misjudged."23 The problem, of course, was that the South, sensing a long-range threat to its "peculiar institution," was now Insisting upon the right to take slaves into the newly-acquired areas of Cal1fornia, Utah, and New Mex1co. Channing Insisted that these areas had come into the United States as free

22 H1story, VI, pp. 62-63. An 1nteresting s1delight of th1s chapter 18 Channing's treatment of the Cuban ep1sode of the 1850's. The 0stend Manifesto he labeled as "und1plomat1c," and he considered the United States to be "clearly in the urong" in the entire affair. (p. 58)

$$
\text { 23In1d.. P. } 74 \text {. }
$$


territory, since slavery as such did not exist in Mexico, and that the question, therefore, was whether they were to remain free. 24 Th1s obviously affected his coverage of the entire controversy culminating in the Compromise of 1850. Channing saw that the general prosperity of the 1850 's did a great deal in bringing the South to acceptance of the Compromise; it "drove thoughts of secession away from the Southern mind," he sa1d. But Danie1 Webster was Channing's hero of the hour:

Looking backward, it is astounding to realize the accuracy with which Danlel Webster sensed the situation in the South and recognized that a concession on the part of the North, like that contained in the Fugitive Slave Act of 1850, would cut the ground from under the feet of... [Southern radicals] and put off the inevitable crisis until the North should outstrip the South in man power and material resources--so much so, indeed, that possibly secession and war would never come. As one reads h1s "Seventh of March Speech" one real1zes that Webster was trying to say to his countrymen: "Make this concession to our Southern brethren!. They love the Union, they want to remain in 1t, but they have been led to belleve by thelr political chlefs that you Northerners are designing their ruin and the ruin of their social system. The concessions made in the Compromise Acts as a whole do not amount to much, apart from the Fugltive Slave Law, for slavery can never profitably exist in New Mexico and Utah and the Fugltive Slave Law is only the carrying out of the plain provisions of the Constitution of the Un1ted States." The abolition propagandists of the North turned upon him with a fury that showed they real1zed that what he had done was to put an end for the time being to their schemings. There are no more painful, no more unjustifiable, ines in 
American poesy than those in John Greenleaf Whittier's "Ichabod," describing Webster as the fallen, the lost, the man for whom "the Tempter" had la1d a snare:--

Let not the land once proud of $\mathrm{hIm}$ Insult him now,

Nor brand with deeper shame his dim, Dishonored brow. 25

According to Channing, "No part of the settlement of 1850 aroused so much bitterness, not even the admission of Callfornia as a free State, as did the passage of the Fugltive Slave Law and the attempts that were subsequently made to enforce 1t." W1th this sentiment, Channing himself was fully In sympathy. "A layman ought not to take 1ssue w1th the justices of the Supreme Court of the United States, or an historian to argue with a lawyer," he wrote, "but a suggestion or two may be possible." He did Indeed make some:

Under the fugitive Slave Act of 1850 , a citizen of a "soverelgn State" of the Union might be selzed and taken from the state of h1s b1rth and residence from youth up, to be tried for that which is dearer than life--h1s liberty--simply on the oath of an Inhabitant of another state. The defenders of the Fugltive Slave Law constantiy relterated the statement that the oases of the alleged fugitive slave and of the fugitive from justice were al1ke and that no one objected to the extradition of the alleged criminal as so many persons did to the return of the fugitive slave. In reality the cases were very unilke, The squint of the law was the same as to the murderer or the thief, north or south of Mason and Dixon's line. It was very different as to holding a human being in bondage for life. 26

25 Ib1d., pp. 84-85.

26Ib1d., pp. 101-102. 
To Channing, the most important effect of the act was not the increase or decrease of the number of runaway slaves, the growth of the free Negro colony in Canada, or the spectacular events assoclated with fugltive slave cases: "1t was that these things put together converted hundreds of thousands of people of the North from a position of indifference or of hostility to abolition to a position of hostility towards the slave power," he thought. "It induced hundreds of thousands of voters, who cared very little whether the negro was a slave or a free man, to use all means at thelr disposal to stop the further extension of slavery and to put an end to it whenever they could, constitutionaliy." 27

Channing attached great significance to Harriet Beecher Stowe's Uncle Tom's Cabin in the coming of the Clvil War. "The New England literary and oratorical group has a great responslbility on 1ts shoulders," he began. He took the opportunity to speculate brlefly about the role of the propagandist in history. "From the time of Peter the Hermit to Theodore Roosevelt and Woodrow Wilson, mankind has been ruled by the propagandist," Channing contended. "Whether right or wrong, he has only to shout loudly enough or write virulently enough and public opinion sooner or later will turn in his favor. He will crush his opponent." All this set the stage for his verdict on Uncle Tom's Cabin. It "did more than any other one thing 
to arouse the fears of the Southerners and impel them to fight for independence." 28 A b1t over-stated, perhaps, but probably not as bad as Channing's grandson thought. "Th1s judgment appears strikingly fanciful," he wrote, "and shows that Channing occasionaliy reached some fantastic conclusions." 29

Channing presented himself with unnecessary organizational problems by having a chapter on "Parties, Politics, and Politiclans, 1848-1859." This caused him to have an awkward overlap between this chapter and later ones on such things as the Kansas-Nebraska Act and the Dred Scott case. St111, he did generalize meaningfully about the period. "These eleven years were the most significant in our history," he wrote,

for 1t was then that the Southerners determined to have their own way within the United States, or else to leave the Union, no matter what their numbers might be in comparison with the Northerners; and the people of the Northern States determined in thelr own minds that the time for concession had passed and that there should be no more compromise with slave power. 30

Channing, l1kewise, made some interesting remarks on speciflc political parties of the perlod. It is hard to determine exactly what he thought about the Whig party, for in one place he wrote that 1t "was born of opposition to Jacksonism and died in the effort to 'swallow the Fugitive Slave Act.'

$$
\begin{aligned}
& 28_{\text {Ib1d., pp. } 113-114 .} \\
& 29_{\text {Fuller, "Edward Channing," p. } 127 .} \\
& 30_{\text {H1story, }} \text { VI, p. } 119 .
\end{aligned}
$$




\section{1}

It had no reason for existence other than 1 ts devotion to things that were past." It was an upper class party, he concluded, but "had no princlples, other than opposition to the Democratic control of the government." On the other hand, he wrote in another place that the Wh1g party "had an honorable history and was composed of some of the best elements in American political life and in American 11fe." But if Channing's evaluation of the Whigs was somewhat vague, he was crystal clear on the reason for the success of the American, or Know-Nothing, party. "Know-Nothingism offered a refuge for politiclans and voters who wished to b1lk the real 1ssue of the hour," he wrote, "namely, the expansion of slave territory, as provlded for in the Kansas-Nebraska Act."3I

Channing was quite crltical of the presidents of the 1850's. "Apparently the best recommendation for the presidency In those days was to have been in the public eye and to have done nothing in recent years about which any kind of enthuslasm could arise," he wrote. He had Franklin Plerce and James Buchanan in mind when he wrote that, but he was also quite critical of John C. Fremont. He considered it "grotesque" that the new Republican party chose Fremont for 1ts first standard-bearer, and he speculated, sarcastically, that the candidate's nIckname of "Pathfinder" must have meant that "he popularlzed paths that other people had found. Posslbly to

${ }^{31}$ Ib1d., pp. 124-125, 137, 135. 
the enthusiasts at the convention the person who had found the patins to the West might also hit upon a route to the White House." Channing seemed proud that Fremont had not found the latter route. "The defeat of Fremont has been generally we1comed by historlans," he wrote, apparently agreeing, "for $1 t$ seems reasonably certain that the South would have seceded in 1856 had a sectional President been elected, and certainly the public opinion of the North in 1856 was not in favor of coercling their fellow countrymen back into the Union fold."32 Channing strained to remain objective, and generally succeeded, in his speculations on the controversial point of Stephen A. Douglas' motives for the Introduction of the KansasNebraska Act. He began by admltting that "one's Douglas or ant1-Douglas prepossessions largely influence the 1nvestigator and the historlcal narrator." Channing had a rather high opinion of Douglas himself, for he wrote of h1s "great ablilty, his winning personality, and his power of eluoldating difficult questions to his own satisfaction and to that of his hearers." After considering all the possible faotors which could have motivated Douglas, Channing decided that the best possibility was that it was "the result of a b1t of local Missourl politics," meaning that Senator Dav1d R. Atchison of that state had influenced Douglas to Introduce the b1ll because

Ib1d., pp. 142-143, 143, 144, 145-146. 
of the desire of his constituents for cheap land to the West. 33

Channing caught the essence of the Supreme Court's 1857 Dred Scott decision in one brief sentence. "In reality, Instead of settilng anything in the minds of the people of the North," he wrote, "what the Dred Scott dec1sion d1d was to unsettle their bellef in the impartiality and justice of the Supreme Court of the UnIted States." The other major event of that year, the Panic of 1857, Channing considered particularly important because of the detrimental effects it had on the fortunes of the Democratic party in the industrial areas of the North, making the rise of the Republicans possible there. 34

John Brown was treated w1th moderation by Channing, but in the end came out rather well. Channing seemed to doubt that he was Insane.

He may have been so, but in any discussion of Insanity or of what const1tutes a maniac it 10 perhaps well to remember that the I1ne between the sane and the insane 18 very tortuous and exceedingly diffloult to draw and that suocess or fallure 18 hardly a secure metewand w1th whloh to measure one's sanity or insanity. Besides, in the maroh of h1story, Thermopylae was as desperate as Harper's Ferry, and when one comes to turn over the beginnings of great events, Captain Parker of Lexington on the 19th of Apr11, 1775, or the embattled farmers at Concord Bridge a few hours later on the same day, were likewise tempting fate.

33 Ip1d., pp. 150-157.

34 Ib1d., pp. 196, 200. 


\section{4}

In each case success followed; Greece was freed from Aslatic control,--for a time; the colonies became the United States,--with the ald of France; and within five years from the death of John Brown, the Emancipation Proclamation came from the pen of Abraham Lincoln. In dying, John Brown achieved the success that evaded him when Iiving. 35

The election of 1860 provided Channing his first opportunity to evaluate Abraham Lincoln. He had trouble finding words to show Just how highly he regarded that great man:

To men of his time, Lincoln appeared to be weak and vacillating and to be actuated more by the desires of the moment than by any firm settled policy. Nowadays, we realize that Lincoln was a man of marve1lous power in the management of men and that he had political foresight almost without parallel among the men of mediaeval and modern times who have risen sufficlently above the mass of mankind to cause their doings to be recorded in documents and assessed by students. 36

Lincoln was not only the "greatest of Americans" and "A Master of men,' incomparably above anyone who has ever walked the American stage," he was also "unsurpassed in modern history," and he "produced the most perfect plece of English prose that has yet been written in America," the Gettysburg Address. 37 Iincoln not only set the stage for the election of 1860, he also "struck the keynote of the history of the United

$$
\begin{aligned}
& 35 \text { Ib1d., p. } 221 . \\
& { }^{36} \text { Ib1d., p. } 299 .
\end{aligned}
$$

37 Ib1d., pp. 388, 309, 295, 228. Channing found only one occasion to be critical of Lincoln, and he emphasized $1 t$ so strongly that one gets the feeling he must have been trying to prove his objectivity. He labeled Iincoln's support of re-colonization of the Negro in Africa "one of the most remarkable fallures of Lincoln's whole career." (p. 525) 


\section{5}

States for the next seven years" when he made his famous "house divided" speech in 1858. By the t1me of the election, according to Channing, the Republicans "stood for distinctly Northern desires, economically and soclally, and formed, therefore--quite 1rrespective of the slavery 1ssue--a sectional pol1tical party." Strangely, Channing seemed almost to lament the election of Iincoln in one passage. "It would seem that if Bell and Everett had been chosen," he wrote, "no Southern State would have seceded and there would have been no war, and In the fullness of time, slavery would have ylelded to the new spirit of the nineteenth century, or, at all events, to the spirit of the twentieth century." Two factors, however, made this outcome impossible: the activities of Southern radical secessionists, and Lincoln's determination not to yleld on the extension of slavery. 38

Nowhere in this volume did Channing actually inform the reader that he was going to discuss the causes of the C1v1l War and then proceed to enumerate them. And certainly he was

38 Ib1d., pp. 229-230, 232, 253. Speaking of the southern radicals, Channing wrote: "They had brought about the existing orisis--at least so it would seem--to serve as a pretext for secession and, having succeeded in that, they were absolutely opposed to any sort of concession to the North. And they were absolutely right, if the Southern soc1al system were to live, 1t must live under 1ts own government. It was so out of tune with the opinion of mankind that 1t could not exist under the domination of any other rulers of the white race. It 18 extraordinary that any set of people should have likened themselves, as many typical Southerners did, to the lords and ladies, to the thanes and squires of the pages of Sir Walter soott and not have realized that a mediaeval state of society could not exist in the modern world." (p. 254) 


\section{6}

no single causationist, holding, for example, that slavery

was the one and only problem which led to the conflict. Still, if one makes the effort to piece Channing's comments on this subject together, a pattern does emerge, and probably a much more real1st1c idea of how the war came about than can be gathered from historlans who strive to prove one particular theory. One of Channing's most helpful passages for understanding the sectional conflict came not in this volume at all. but in his fourth, Federalists and Republicans:

Sectionalism had begun with the first settlement of the country, owing to the different industrial conditions of the reglons then occupied. The same sort of people went to V1rginia and to New England; they desired to do similar things, but were forced to adapt themselves to their natural environments. The Virginians tried to introduce concentrated municipal Iffe, entirely without success; the Massachusetts leaders attempted to work their lands in large units; they were obliged to content themselves with farming on a moderate scale and to ut1lize the rest of their strength in commerce and in the rougher forms of manufacturing. The separation between agrarian and cap1talistic effort was not so pronounced in New York and Pennsy 1vania, or, perhaps, it would be better to say that both were present in the Middle Colonies. These primal differences were soon greatly accentuated by the introduction of black servile labor, which proved to be unsulted to the North and most congenlal to the South. With the development of slavery the southern agriculturist became a mag.nate, the white race an aristocracy, and 1ts more prosperous and stronger men a true landed ol1garchy, ... the "Virginia Lordilngs," as Stephen H1gginson termed them. They soon came to have the contempt of the1r. class for trade, for shop-keepers and mechanics; and they feared capitalists. Whether the people of these several sections could ever work together in reasonable harmgny was distinctly a question for the future in 1789.39

${ }^{39}$ Edward Channing, A History of the United Stated. 
And how much more questionable it was in 1850 or 1860 !

"One of the distinctive lines of thought that separated the North and the South," wrote Channing in volume VI, "was on the question of the constitutional position of the States within the Union. In the North, the general opinion was that the Union was sovereign and the States part of 1t." He realized it had not always been so, evidenced well enough by the Hartford Convention. But thanks largely to the "economic inter-dependence of the Northeast and the Northwest and the extremely profitable relations that existed between the manufacturing and commerclal parts of the Northeastern States and the slave-holders of the South," it was so by 1850. Channing also felt that "The ldea that the people of the United States formed one nation had been powerfully reinforced by the coming of the immigrant from abroad," for they came, after a11, not to a state, but to "The United States and looked upon it as their adopted home." In the South, on the other hand, "every white boy and girl grew up to regard himself or herself as born into the service of his or her state and as owing, not merely alleglance, but devotion and life itself to her protection and to the furtherance of her well-belng." The only "feeling of solidarity" which Channing could discern among Southerners was "that of the community of Interest of the slaveholding aristocracy and their white nelghbors."40

Volume IV: Federallsts and Republicans, 1789-1815 (New York: The Macmilian Company, 1917), pp. 154-155. 40 H1story, VI, pp. 268-270. "The mot1ves and reasons 
So, Edward Channing doubtless would have largely agreed with something like this as a simplifled statement of the causes of the Civil War: It was the result of a natural, environmentaliy-induced sectionalism in whlch the two leading factors were slavery, economically and soclaily, and the view of the nature of the union, politically; and, in the end, it became a purely emotional thing, for, as Channing wrote, "The psychology of men's actions is of ten beyond the ken of the h1storian; but in this case sentiment overruled every other consideration in the North, - and in the South."4I

In adopting such a broad and moderate view of causation, Channing was ahead of his time. Howard $k$. Beale wrote in 1946 that Channing, "provincial Bostonian and conservative

that led the men and women of the South into secession are as inscrutable now as they were in 1860 and in 1861," wrote Channing. It was a rather strange remark for him to make, for he went ahead to delineate the reasons, concluding that "The great mass of the white inhabitants of the cotton States sincerely belleved that they were in danger of persecution and of disaster and that their 'honor' demanded Independence." (pp. 256, 264-265)

41

Ib1d., p. 315. Louis Gottschalk emphasized the political more in his analysis of Channing's interpretation. "Edward Channing concelved of the struggle as a phase of evolving nationalism," wrote Gottschalk. "The growing nation's alms were ambiguous: Which definition of alms should preva11, that of the North or that of the South? When the South concluded that its definition was doomed, it determined to follow the example of the colonies in 1776 and work out 1ts own destiny. The Clvil War to Channing was a War for Southern Independence, a war to ensure to the South freedom to organize a nation after 1ts own design, free from the Implications of Northern definition." Louis Gottschalk, edo, Generalization in the Writing of History: A Report of the Committee on Histor 1cal Analysis of the Soclal Sclence Research Counc11 (Chicago: University of Chicago Press, 1963), p. 136. 
as he was, emphasized in his ivory tower many of the economic motives and psychological factors generally not stressed unt1l after he published his volume, and even then chlefly by historlans with whom no one would have suspected Channing of agreeing." Also, Channing's treatment of the Clvil war places him squarely in the midst of what 18 now generally referred to as the nationalist school of historians on that subject. Indeed, a recent survey of major interpretations of American history considers Channing one of the leading exponents of the national1st approach, along w1th James Ford Rhodes and Woodrow W1son. Some of the characteristics of this school are: the beginning of a more balanced, less partisan plcture of the C1vil war; the bellef that the war was an "1rrepressible" conflict; and approval of the outcome of the war and subsequent developments such as the growth of industry and the Negro's being forced to accept a subordinate role in American $11 f^{f} e^{4}{ }^{4}$ In 1861, Channing felt, Northerners were divided Into four groups:

(1) the Buchananttes, who represented the old Northern men with Southern princlples; (2) the abolitionists, who were glad to see the Southerners go and the sooner they went--and the farther--the better; (3) the Northerners who had elected Lincoln, but were willing

42 Howard K. Beale, "What Historlans Have Sald About the Causes of the Civ11 War, "Theory and Practice in Historical Study: A Report of the committee on H1storlography (New York: Soc1al Science Research Counc11, 1946), p. 89; and Qerald N. Grob and George Athan B1llias, Interpretations of American History: Patterns and Perspectives. Volume I: To 1877 (New York: The Free Press, 1967), pp。418-421。 
to compromise with the South to bring the seceded States back into the Union; and (4) a few determined men with Lincoln at their head who were resolved that there should be no more compromise that would lead to any possible extension of slave so11.43

Channing showed his open-mindedness toward the South by praising Confederate clvil and military leaders. "Among the leading men of the first group of the Confederate states, there was no one better qualifled for the presidency than Jefferson Davis," wrote Channing. Davis had "a fine mind," and was "an excellent administrator and a good judge of fit men。" 44 As for the military:

The Southern soldiers enjoyed the great advantage of having at the outset half a dozen remarkable men at the Ir head: Robert $E_{0}$ Lee, JoE。 Johnston, Albert Sidney Johnston, $P_{0} G_{0} T_{0}$ Beauregard, Braxton Bragg, and James Longstreet. Albert Sidney Johnston was killed at Shiloh, otherwise these men were in high command at the time of Appomatox [sic] and their presence with the Southern armies was worth many regiments, divisions, or army corps. On the Union side, there were no such outstanding military figures in the early months. 45

After the "early months," there were. Among Northern generals who were praised by Channing were George $\mathrm{B}$. McClellan

43 History, VI, p.289. Channing considered Buchanan "an experienced and tried Democratic politician of the old school," but "Infirm in body and mind." (p.281)

${ }^{44}$ Ib1d., p. 277. Channing showed an even more sympathetic attitude toward Davis on pp. $624-626$.

45 Ib1d., p. 326. Thomas J. "Stonewa11" Jackson and J. E. B. Stuart were also pra1sed by Channing, Stuart as "one of the outstanding military flgures of the war" and Jackson as "one of the few military genuises that the war produced" and the Confederacy's "greatest soldier." (pp.480, 469, 478) 
("He exh1b1ted remarkable organizing ab1l1ty and brought discipline and military cohesion within a few months into the Army of the Potomac that remained w1th it through years of campalgning, disaster, success."), Winfleld Scott Hancock ("one of the most brilliant soldiers in the army"), W1111am Tecumseh Sherman ("the war probably produced no greater strateg1st and tactician"), Philip H. Sheridan ("one of the foremost flghters of the century, in America or in Europe"), and U. S. Grant:

The poet in his study has, of tentimes, estimated a man better than the orator or the historian; so James Russell Lowell at Elmwood in Cambridge, Massachusetts, appraised Grant:--

"Strong, simple, sllent... such was he
Who helped us in our need; the eternal law
That who can sadde opportunity
Is God's elect..
Was verifled in him." 46
Channing must have really had that high an opinion of Grant. One of Channing's former students and assiatants recalled: "Once he threw me out of his office for making what seemed to him a disparaging remark about Grant as a General, and did not let me back for over a month." 47

Channing again showed his great ab1lity to dist111 the essence of war into a few brief passages in his treatment of The War for Southern Independence:

46 Ib1d., pp. 403-404, 481, 558-559, 573, 557. A more detalled evaluation of McClelian appeared on pp. 474-476. ber 26,1966 .

47 Ietter to the author from Herbert W.HIII, Septem- 
At flrst glance, running over the statistics of population and production of the States that seceded and of those that did not secede, viewing their differing economic interests, and bearing in memory the outcome, one 18 amazed at the hardihood of the Southern leaders in pressing their people into inevitable and hopeless conflict. In real1ty, their cause was not at all hopeless, nor was defeat inevitable; and 1t did not seem to be nearly as hopeless as it was to the Southern leaders whose horlzons were bounded by their own little local1ty and who possessed nelther the training nor the desire to study the soclal, economical, and International relations of the countries of the world. Three flxed beliefs strongly affected them: the one was that cotton was "KIng" and that the cessation of exportation for a few months, or years at most, would bring the nations of Europe to their knees in supplication to the Southerners to plant cotton, and would even bring about the recognition of the Southern Confederacy by Great Britain and France. The second 1dea was that the North would not fight, that secession would be peaceable. The third 1dea was that if the Federal government did attempt to coerce the South, the people of the Oh10 Valley would not rally behind Lincoln and his Black Republicans. In all these three expectations the Southern leaders were wrong. 48

The problem with the first of those three beliefs was that the British did not need cotton as much as they needed wheat; as Channing said, "For the time being wheat had usurped the position of royalty in the economic fabric of the United KIngdom that cotton had occupied." 49 The first battle of Bull Run convinced the North that 1 had to fight, and thus made the second bellef wrong.

The third bellef, concerning the OhIo Valley, occupled most of a chapter for Channing, "The Decision of the Oh10 Valley." "As matters were," he wrote, "the outcome of secession depended ultimately upon the attitude that the people of

$$
\begin{aligned}
& 48_{\text {HIstory, }} \text { VI, pp. 332-333. } \\
& 49_{\text {IoId., p. } 341 .}
\end{aligned}
$$


the Oh10 Valley assumed."

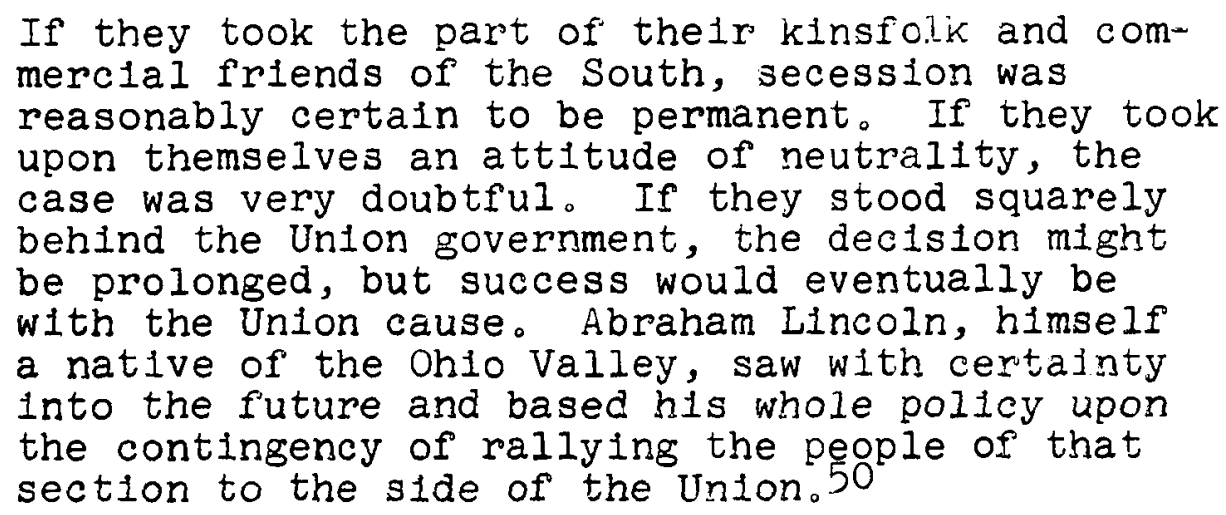

It was not as much a foregone conclusion as one might think, Channing made clear, that this region would choose the third alternative. The southern portions of the states there had been settled by southerners and had close economlc tles with the South. It was only transportational links w1th the Northeast, particularly rallroads, which kept the cruclal onio Valley loyal to the Union. 51

Another place where Channing generalized meaningfully was in discussing the changing art of warfare:

In ages past, in the times of Alexander and of Caesar, of Wallenstein and of Napoleon, the abllity to march long distances and dey after day, to carry welghts, and to ride on horseback were of the first necessity for the soldier. It was a man trained to outdoor life, to delving in the soll, to following the plow, or to ranging the woods, who was useful in war. It followed that an agricultural country was the strongest country for military purm poses, that cattlemen, herdsmen, and shepherds were the best soldiers. By 1860, the art of war was beginning to take on the industrial phase in which

50 Ibid., p. 374 .

51 Ib1d., pp.375-379。 
machines and not marchers were to be supreme. In the future, soldiers were to be transported by ra11 or boat, instead of marching hundreds of miles to the flelds of battle. And when in front of the enemy, artillery, and not infantry or cavalry, was oftentimes to be the declding factor. It is a long way from the horse-frightening cannon of cressy and Polctiers to the seventy-five-mile carrying gun of the year 1918. The War for Southern Independence came in the mid-interval. It came at the moment when machines, from the steam-1ocomotive to the breech-loader and the torpedo, were beginning to play their parts. The war was to be aged industrially as no war had ever been waged before. In this regard the South was hopelessly handicapped and the outcome was in the hands of the Northern people, provided they stood fast. 52

And finally, Channing saw the character of the conflict as going through three stages, "first a war of coercion, next a war of conquest, and, finally, a war for the destruction of the Southern social system." "In 1ts final stage," he elaborated, "the war developed into a campaign fon the destruction of the economic foundation of Southern life which entailed sufferings upon the Southern people and aroused a spirit of the south and in the North that it took decades to I1ve down." "The two most lamentable fallures of the war," according to Channing, "were the lack of the care of the slck and the wounded and of the prisoners." 53

Of military campaigns as such, little need be said. Channing showed his usual abli1ty to make them understandable;

52 Ib1d.,pp.581-582。

53 Ib1d., pp. 435-436. Channing thought the blame for the controversial Andersonvilie "belonged on the utter breakdown of the Confederate administrative bureaus" rather than on any maliclousness on the part of southerners. ( $\left.p_{\circ} 442\right)$ 


\section{5}

two recelved his highest praise. Grant's campaign at Vicksburg was "one of the most brililant operations in the annals of war." The bad effects of Sherman's "March to the Sea" were played down and its accomplishment built up. Typlcal of the plain language employed by Channing in military history was the phrase "as the crow flies" to indicate a straight distance. Another use of the same idea was Channing's famous description of the Shenandoah Valley after Sherldan's campaign there: he "left the Valley in such condition that a crow flying over it would have to carry his food with him." There must have been some Westerners appalled at Channing's coverage--or lack of 1t-oof the West in the Civil War: "We can dismiss at once the country beyond the Mississippl, for the campaigns in that region, after the very beginning, had slight significance。" And that was all! Typically, Channing devoted an entire chapter to "The War on the Water and Trade with the Enemy." It was high-lighted by his detailed account of the MonitorMerrimac conflict, with his conclusion that it "spelled the doom of the existing navies of the world."154

"The Election of 1864" was a very weak and poorly= named chapter near the end of this volume. Channing's comments on the election 1tself actually fllled only about five of the thirty pages; page headings included everything from the westward movement to negotiations for peace. The few things he

54 Ib1d., pp. 552, 562, 456, 575, 445, 504. 


\section{6}

did say about the election were quite strange. "From the van" tage point of the twentieth century," he wrote, "1t seems reasonably clear that at no time in the year 1864 was the reelection of Abraham Lincoln within the realm of doubt." The fact that Lincoln had the "plain people of the North" behind him was the reason for this statement; they greatly outnumbered his opponents, Including Radical Republicans, Peace Democrats, and the extreme abolitionists. These latter groups simply showed up well because they were so "mighty in speech and pen。" "For almost the first time, Lincoln's political instincts failed him," sald Channing in reference to Lincoln's famous note of concern about the probablifty that he would not be reelected. "Possibly a recurrence of one of those depressive eras that marked his earlier life for a time clouded the clearness of his vision."55 Noting the closeness of the election's outcome in the three crucial states of New York, Pennsylvania, and Oh1o, Channing concluded:

Had these three States gone the other way and been jolned by a couple more, the election would have been fairly close; McClelian might have been elected; and the history of the next few months might have been very unlike what it was ${ }^{-1}$ there would have been no march to Appomattox. 56

The final chapter of The War for Southern Independence is entitled "The Collapse of the Confederacy." It is an

$55_{\text {Ib1d. }}, \mathrm{pp} 。 605-606$.

56 Ib1d. p. 610。 


\section{7}

excellent example of Channing's problem-3olving technique. He began w1th the assumption that the Confederacy was not m111tarily defeated in April, 1865. "The Southern people, had they so wished, could have held out for a long t1me," he wrote. Why, then, the sudden collapse? Rejecting the 1deas that it was due to a lack of either war material or of food, Channing concluded that the answer was a loss of morale. "It is abun" dantly evident to the underwsurface seeker that by the summer of 1864 , and even more so by December of that year, the w111

to flght had gone from large sections of the Southern people." 57 Allan Nevins has made a useful oriticism of Channing's analysis of the causes for the collapse of the Confederacy. "The conclusion Channing reaches is not satisfactory" for Nevins; "it evades the question, Why did morale collapse?" Nevins' major point, however, is that Channing oversimplified in attributing the sudden Southern collapse to a loss of morale alone. "He overlooks the fact that 1 t may have been, and probably was, a confunction of all the elements he has named... which brought about the surrender." Alsom-and what a strange, but true, crit1c1sm this is of Edward Channing! we "He ent1rely overlooks one highly important element, the collapse of transportation." "Altogether," Nevins concluded, "Channing attributes too much to a single factor in a complex situation."58

57 Ib1d., pp. 612-621. 58 Allan Nevins, The Gateway to History, New, revised edition (Garden City, New York: Doubleday and Company, Incorporated, 1962), pp. 241, 243-244. One reviewer, on the 
There is an interesting footnote which can be added to the problem of why the Confederacy collapsed. Sometime between 1906 and 1925 Channing changed his mind about the reasons. In the former year, he wrote to Charles Franc1s Adams:

The blockade and the economic upbullding of the North during the war were the two most potent factors in ruining the South. Sometimes when I have thought on the matter for some weeks I find myself asking what would have happened had the Union armies stood on the defensive and simply enforced the land blockade? Would not the result have been the same and in about the same period of time and with one tenth of the cost of men and money?59

One of the most interesting critiques of Channing's sixth volume never appeared in print. It was by his colleague, Albert Bushnell Hart. He wrote Channing a letter on November 2, 1925, saying he had just completed "a careful line by line reading" of the book, and praising it in unbelievably glowing terms. He told Channing he had "produced a notable, permanent and unbiased history of the most dramatic period in the history of the United States." "I am amazed at the penetration of your book throughout," he continued. "Channing, you did Indeed hold the mirror up to nature." "I know no writer who takes greater pains than you to put himself into the times about which he

other hand, no less a historian than W11l1am E. Dodd, was completely satisfled with Channing's interpretation, feeling that it was "surely going to be the final verdict on this part of the subject."--New York Tr1bune, August 9, 1929.

59 Edward Channing to Charles Franc1s Adams, January 6, 1906, Adams Fam1ly Papers, Charles Franc1s Adams II File, Massachusetts Historical Soclety Library, Boston. Channing specifically minimized the role of the blockade in the History, VI, pp。519-521。 
writes; to give every important confilet of opinions a falr hearing and a falr showing." To Hart this was Channing's finest work. "Above all, my dear colleague, I recognize that throughout the book that $[\underline{\mathrm{s}} \mathrm{c}]$ quality of fearless truth which has characterlzed a.ll of your historlcal work." And finally, the conclusion: "We have been coworkers and friends for many years, but I have never appreclated your gifts as an investigator and writer and a medium of truth as I have in reading this volume." Amid all this, there was only a brief hint of what was to come. Hart sald he had noted in his copy several "queries," "marks of approbation," and "sometimes," "a difference of opinion"; he would gladly type these up and submit. them to Channing if the latter desired. 60

Channing must have been thrilled with that letter. "I opened your letter with fear and trembling," he replied to Hart, "and was astounded and gratified at what I read therein." He cont1nued:

In point of fact, I read it three times! I think that you have shown a most wonderful spirit toward your anclent colleague, for there must be hundreds of things in that book that were most distressing to you. I tried to set these things before the reading and studying world with entire truth, but in such a way that no one's feelings would be hurt. I am glad to feel that I succeeded.61

60 Albert Bushnel1 Hart to Edward Channing, November 2 , 1925, Albert Bushnel1 Hart Papers, Harvard University Arch1ves, Cambridge, Massachusetts.

${ }^{61}$ Channing to Hart, November 3, 1925, Ib1d. 
Channing concluded by saying he would be glad to have the typewritten comments. He must have been astounded again, but certainly not gratified, when he recelved them. Hart gave him nine pages of detailed, sometimes biting, critlcism-cand this only covered the first 197 pages! It was filled with "differences of opinion"-wbut Hart was rather dogmatic in his positions--"errors," "queries," references to Hart's own books, etc. 62

One point to which every commentator on this volume addresses himself is Channing's attitude toward the South. Hart praised Channing in the November 2 letter for his "detachment from sectional prejudice." 63 Channing's grandson forthrightly stated that "Never before had Channing taken such a pro-Southern point of view." Strangely, he concluded that the result of this was "a falr analysis of the Civil war and its causes."64 David Seville Muzzey, reviewing the volume for the Political Sclence Quarterly, wrote that Channing "regards the aggressiveness of the Abolitionists as mild in comparison with that of the Southern fire-eaters." Channing, he sald, felt that slavery led to secession, and that secession was a crime and a blunder. "We doubt if Professor Channing's volume will

62 Ibid. The document is headed: "Queries on Channing's History of the United States, Volume VI, Put by Albert Bushnell Hart, November 4, 1925。"

63 Hart to Channing, November 2, 1925, Ib1d. 64 4 Fuller, "Edward Channing," p. 126. 
meet with a wholly hearty reception south of the Mason and Dixon line," concluded Nuzzey; he even thought the title mis. leading, for it was not, he said, as much of a concession to the Southern apologist point of view as The War for Southern Independence implied。6 65 Charles Beard expressed the same view in his typical iashion. "It is not probable that any right thinkers will approve this book, the Daughters of the Confederacy least of all," he wrote in the New Republ1c. "Doubtless that tribute w111 be paid to 1 ts excellence."66 on the other hand, a Southerner, B。B.Kendrick, reviewing the volume for Historical Outlook, praised 1ts "spirit of detachment and 1mpartial1ty。" Kendrick sald he was an "only partially emanc1pated" Southerner, and he found the book not only fiair to the South but sometimes even flattering. Charning commented on this review to Brett: "It was written by a Southerner and finds no cause for serlous resentment in the book. I am afra1d we w111 have to hire somebody to chop it up with a meat axe."67 Probably the only safe conclusion to draw from all this is that persons were reading between the lines in Channing's History on the st1ll-emotionalized tople of the C1vil War to

${ }^{65}$ David Sev1lie Muzzey, Polltical Sclence Quarterly, XL (December, 1925), p.624。

${ }^{66}$ Charles A。Beard, "H1story and an Antidote," New Repub11c, XLIV (November 11, 1925), p。311。

$67_{B}$ 。B。Kendrick, Historical Outlook, XVI (October, 1925), pp. 283-284; Channing to Brett, October 10, 1925, Macmilian Collection. 
get what they wanted out of 1t. Channing must have strived consciously to be falr to the South, just as he did to the West; but in both cases, he did not always succeed. One of h1s southern students, a distant relat1ve of Jefferson Dav1s, recalled Channing's comment to Eva $G$. Moore when he entered Channing's office: "Give me my cane-rI don't want him to attack me!" But he also remembered Channing talking a great deal about trying to be fair to the South, and specifically being proud of the title for his sixth volume because he thought 1t was falrer than "C1v11 War."68 The most moderate, and probably the most accurate, statement on Channing's treatment of the South was made by Carl Russell F1sh. "Southerners w111 not be altogether pleased with his handling of Southern problems," F1sh wrote, "and yet h1s book is a marked advance over that of Mr. Rhodes. He treated Southerners as equals, w1thout condenscension, and he realiy understood the south better than his predecessors, even when not approving of 1t."69

Besides the review by Kendriok, there 1s only one other on which Channing's opinion 1s avaliable. It was by W1111am Macbinald and appeared in the Nation. MacDonald orltiolzed Channing for being weak on economio and soc1al history and too

68 Interview w1th Hugh 0. Dav18, September 22, 1966 , Tulsa, Oklahoma. Davis also recalled of his student association with Channing: "I belleve that I was his last student. The only reason that he 'took me' was that I was a southerner and distant kin of 'Pres. Jeff,' and he was a bit partial!"-. Letter to the author, August 2, 1966.

${ }^{69}$ Carl Russe1I F1sh, "Edward Chann1ng: Amer1ca's H1storian," Current H1stony, XXXIII, (Merch, 1931), p.865. 
brief on forelgn aftairs; but.h1s-general impression of the book was favorable. Still, Channing did not like 1t, "William MacDonald seems to have evened up matters with me in a recent number of "The Nation," he wrote to Brett. "I suppose for turning down the book that he asked you to publish. It is of no matter," Channing consoled Brett, and himself, "because MacDonald pla1nly had not read the book and nobody nowadays reads 'The Nation."170

Of the many other reviews, only two are worthy of spe clal nore. One was by Beard. Here 1s the heart of 1 t:

The dissertations of scholans, the burled articles of specialists, and the upturnings of local historians have all been raked over, sifted, and examined in the cool light of a trained mind. Extreme statements are avolided; a judiclal atmos phere pervades these pages. Those who want to know what doctors of philosophy think about the events and characters of the period must read this volume.

Reard complained about Channing including social and literary history in volume $V$ but not in volume $V I$, where, he felt, it was really more important. "The world is full of a number of things," he concluded, "and our author has put several of them together. That is his right。" And, of course, Beard had to get in his usual economic criticism. He took Channing's remarks about two distinct socleties existing within the United States by 1860 to mean that Channing thought economic differences were

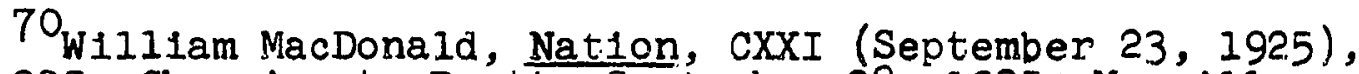
pp. 334-335; Channing to Brett, September 28, 1925, Macmilian Collection.

${ }^{71}$ Charles A Beard, "History and an Ant1dote," New Republic, XIIV (November 11, 1925), p.311。 
at the heart of the irrepressible conflict, and then queried: "If this analysis is right, and it seems to be right, then why a book telling in the main the traditional tale? The revlewer surrenders。"172

Dixon Byan Fox, in the American Historical Review, noted the intentional IImltations of Channing's work. "One lays down the volume.owlth his knowledge and bellef revised In detail, but not as a whole," he wrote. He must have Irked Channing considerably when he went on: "Th1s is not the kind of general interpretation that Mr. Beard may some time write of the great crisis; one discerns no themat1c pattern such as might mark a similar work of Professor Turner." Fox also noted that there was "less attempt in this volume than in its predecessor to swing the whole clrcle of American life," meaning, of course, to cover non-political developments. His over-a.1 Impression of the book, however, was favorable. He found Channing's thes1s concerning the collapse of the Confederacy stimulating, and he concluded:

It may be said in generale:and it is high pralse Indeed-w that Professor Channing's sixth volume just1fles the hopes of his readers, that every page is marked by the trace of an original mind, functioning rather obviously in New England but severely resolved to be falr, and that his story is told with a perfect clarity of statement leaving no one at any time in doubt as to exactiy what he means.73

\section{Ib1d.}

73D1xon Ryan Fox, American Historical Review, XXXI (October, 1925), pp. 151-154。 The other reviews of volume VI are: Bookl1st, XXII (December, 1925), p。111; Independent, 
Perhaps Allan Nevins' Judgement on Channing's sixth volume is the most meaningiul and valid one of all. He noted that "some comprehensive histories resolve themselves, upon close examination, into a clear succession of problems freshly restated, freshly attacked, and freshly resettled." Channing's work he considered an excellent example of this. It was by no means a full narrative of the years 18481863 , omltting much that one would normally expect to find in an account of those years, and yet much that it did contain was novel. "Leaving out the familiar story of Congressional battles, foreign diffculties, and Clv1l war campaigns, [a slight exaggeration] it attacks distinct questions as if no historian had ever dealt with them before."174 or, as Nevins stated it in another place, it "offered a score of analyses of problems, consistentiy declining to draw them together upon any interpretive thread."175 He concluded:

No critic would call Channing's"history an 1deal work. It is addressed too much to the speclalist and too little to the lay reader; it lacks continuity, symmetry, and completeness; and the sucm cession of problems gives it a jerkiness that is inimical to literary finish. At the same time,

CXV (July 18, 1925), p。 79; W1111s Fletcher Johnson, "Studies in History, "North Amer1can Review, CCXXII (September-OctoberNovember, 1925), pp。177-187; $C_{0}$ M。 Morrison, New York Evening Post L1terary Review, September 5, 1925; Outiook, CXII (December 23, 1925), pp. 6410642; Wiscons in Library BuIletin, XXI (October, 1925), p。230; and E111s Paxson Oberhaltzer, "American Annals," Saturday Review of L1terature, II (August 22, 1925), p. 61. Oberholtzer, disclple as he was of McMaster, had to complain about Channing not using newspapers as sources.

74 Nevins, The Gateway to H1story, p.231. 75 Ibid. p. 267 . 
1t 11lustrates the means by which the best historians attain penetration and originality.7

In 1926, Channing"s "harvest season," as Samuel Eliot Morison called 1t, reached its peak. The War for Southern Independence recelved the Pulitzer Prize, and Channing was awarded an honorary degree of LItt.D. by Columbia University and elected a fellow of the American Academy "Channing greatly enjoyed this public recognition, although it was both unsought and inexpected," according to Morison. "He had never played academic politics, or catered to the critlcs, or courted favor from any man." 7 ?

Channing ald not allow all this acclalm to keep him from going on with the Great work. When he originz?iy planned the project back in the $1890^{\prime} \mathrm{s}$, he had thrught in terms of: elght volumes. As the years went by, he consldered several different possible approaches, but in the end 1: made no dit" ference: the seventh volume, v1rtually complete when he died, was never published.

It is interesting to trace the evolution of Channing's thoughts on the H1story in his correspondence witr: Brett, For some reason, as of 1922 the contract with Macmlilan called for

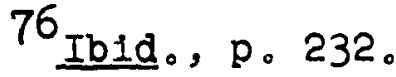

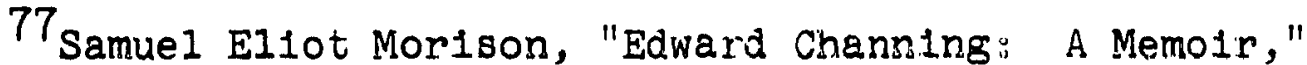
Proceedings of the Massachusetts Historical Society, LXIV (October, 1930-June, 1932), po283. There 1s a copy of the letter from Frank D。 Fackenthal, Secretary of Columbia Un1versity, to Channing, informing him of the Pulltzer Prize award, In the "Resignation" folder in the possession of Elizabeth Channing Fuller. 
only seven volumes. In October of that year Channing wrote concerning the possibility of adding anotnes, bringing the narrative down to 1912 , rather than stopping w1th the end of the Span1sh-Amer1can War as planned. "Indeed," he continued,

1t would seem desirable to bring some of the toples having to do with 1ndustrial conditions and labor conditions, and especlally with the financlal development of the country down to an even later date.... In outining these later volumes in my mind, I find myself regarding the new industrial development of the United States as beginning in 1861 with the secession of the cotton States, the inauguration of A. IIncoln, and the departure of the Southern Senators and Congressmen from the national legislative body. This gave the North a chance to reverse the half-century old polloy of the federal government--as long as 1 t had been in Southern hands--and bul1d up the agricultural and industrial interest of the North and they devised their taxing systems, land aystems, etc., with that end in view. In fact the industrial development of the four years of the war time belongs with the industrial development of the later years. Do you see any objection [to] my leaving it out of volume v1--except as explaining the preoocupation of the people in other pursults than war-and shoving the extended treatment into volume v11?78

It was later in that year that Channing had trouble with his eyes, but then declded he would be all right by cutting down on h1s schedule slightly. And Brett seems to have responded favorably to Channing's 1deas about another volume, for Channing mentioned in a letter in December that it was already being advertised that way. 79

\footnotetext{
${ }^{78}$ Channing to Brett, October 18, 1922, Macmilian Collection.

${ }^{79}$ I010., November 6 and December 14, 1922.
} 
In July, 1925, the next month after volume VI was pub lished, Channing specifically informed Brett that he had begun work on volume VII. A month later he was saying he was exhausted from writing the first chapter, and suggesing it might be better to "print a one volume book on the last fifty years." In September he was planning a trip abroad with "the missus" to "get up steam for Vols。 $7+8$ " "The next month he expressed some doubt as to whe ther the eighth volume would ever be completed. "Of course, I could speed up on the prow duction," he speculated, "but where so much obloquy has been showered or Rhodes for the declining character of his last two volumes, I feel hardly like doing that." 80

The four letter of the preceding paragraph might imply that Channing was approaching old zge, and realized it. in December of 1925 he wrote a letter to Brett which made this quite clear. Brett had been 111. "As we grow on and approach middle life exou and I we are liable to have some of the troubles of midale life," he told his frlend and publisher。 81 When he wrote the letter, he was seventy years old; from that point on, the problems of his age become increasingly apparent. When he commented on his work now, it was "poking" along; and he showed the oldster's concern about "progress" in the form of commercialization in the Cotult area. Brett seemed to sense

\footnotetext{
29, 1925. ${ }^{81}$ Ib1d., December 8, 1925.
}

${ }^{80}$ Ib1d., July 3, August 21 , September 13, and October 
the situation. He felt compelied to praise Channing in a letter of August 4, 1927-0though he doubtless had in mind spurring Channing on also. "As you know, I have been looking forward to the completion of this set of books as one of the really worth while things I have had to do with in my fifty years of publishing," he told his agling historlan. 82

On January 21 , Channing wrote a letter "To the Presi" dent and Fellows of Harvard College" seeking permission to retire from teaching. "May I take this occasion to expreis my gratitude to the President and Fellow for the1r consideration of me for nearly half a century," he sdded.83 H1s retirement was approved effective August 31 . Its announcement occasloned dozens of letters from former students and friends, including Howard K. Beale, Roger B. Merriman, Artmur Lyom Cross, and James Phinney Baxter III, and a telegram from the two Adolph A. Berles which is typical in its comments:

ON THE OCCASION OF YOUR RETIREMERT TWO GENERATIONS OF ADMIRERS SALUTE YOU IN RECOGNITION OF MANY FRUITFUL YEARS AND VOICE THE HOPE THAT MANY MORE GOLDEN YEARS REMAIN STOP AMER.ICAN HISTORY OWES A DEBT TO YOU WHICH WILI BECOME GREATER AS LATER SCHOLARS CARRY ON YOUR WORK STOP YOUR STUDENTS CARRY YOUR IMPRINT IN THEIR LIVES AND WORK AND ARE GLAD TO JOIN IN THE DAY OF YOUR HONORO4

82 Ib1d., March 19, 1926, August 3, 1927, Brett to Channing, August 4, 1927 .

83 Channing to President and Fellows of Harvard College, January 21, 1929, Lowell Papers.

84 folder. The telegram and letters are in the "Resignation" 
The day they spoke of was March 11. A group of' Irlends, colleagues, and former students collected money and commissioned Charles Hopkinson to paint Channing's portra1t; it was presented to the university on March 11. Approximately fifty persons attended the occasion, held in the faculty room at University Hall. John Channing Fuller, flye year ola son of Channing's daughter Elizabeth, unvelled the portrait. Morison, who made the presentation, recalled that Cranning "radiated benevolence" on that happy occasion. 85

Channing's old age and retirement apparentiy did not affect the vitality of his personality. A person of the library staff recalled asking him a question, shortily aftier he had recelved emeritus status, about a certain graduate student. Channing became very interestes ar first, even going to the nearby stall of the student to see if he could figure out the answer from the materials thereon. Trien, suddenly, he became very nonchalant about the whole aifalr. Turning away, he said, "But, I don't have to worry about those things now." And, skipping merrily down the alsle with hands in pookets, he chanted, in a sing song fashion, "I'm a profeesor emeritus, I'm a professor emeritus.o."waking no note of the heads of

85 Morison, "Edward Channing," p.283. A briet" article on the event appeared in the Boston Hera1d of March 12, 1929. (clipping in "Resignation" folder.) The portrait now hangs in the Union Catalog room of Widener Itbrary. 
curious students popping out here and there tc investigate the asturbance. 86

The retirement doubtless gave Channing even more time to work on his H1story. Even though he wrote to Brett in May, 1930, that he was off to England and Scotland because "Phe IOId Man' feels rather tired," he was through his part of volume VII the next month. The only thing left was for his secretary, Eva G. Moore, to check the footnotes. "And, as you ane well aware, the foot notes to the pages of the great work are the most important part of 1tg being," he wrote. This brings to mind again the crucial role of M1ss Moore in Channing's work; it seems to have become more and more cruclal as Channing grew older. He hinted at this in the same June letter. "I rave an Idea that the text of the new volume will te ready by cotober," he told Brett, "but the Lord and Ladywotherw1se known as my Secretary-are the only persons who can give any information as to when the footwotes w1II be completed." In August he stated It even more expl1c1t1y: "M1ss Moore Informs me that this book cannot come out until next spxing, wand she knows a good deal more about it than I dow-for she has to msike sure that no lies are told in the text." Channing tried to console Brett. about the delay by telling him he thought the work, which he was planning to call "From Appomattox to Santlago," was going to be "a whacking good volume." 87

${ }^{86}$ Interview with Robert H. Haynes, August 24, 1966 , Cambridge, Massachusetts.

87 Channing to Brett, May 13, June 25, and August 6 , 1930, Macmilian Collection. 


\section{2}

Channing's declining mental vigor and reliance on Miss Moore came out even more forceililiy in a series of letters be wrote to her in his last days, mostiy while he was in cotult and she in Cambridge. He began to become concerned about whether the manuscript for volume VII was long enough to match weIl the others in the seriesw"Please look up length ot Vol $1^{\prime \prime . . . ~}$ and apparently even asked her to elongate it as she typed: "I hope that you are elongating Vol. 7 as you go along," he wrote. "It must be big enough to stand with the rest + give us a chance for an elgith volume with the General Index." 88

Though Channing "appeared to most people his uaual ruddy and healthy self" to the very end, "to his zamily and closest frlends there semed to be a distinot slackering of his mental and physical powers from the yes. 1920" The American H1storical Association held its meeting in Boston in 1930, but Channing did not attend; he did not even feel well enough to recelve old friends and students who wished to call on him to pay their respects. 89 He died a few days latex, January 7 , 1931. He was working in his study to the very end; Nis Moore had not completed her portion of the seventh volume, for it was sti11 not in the hands of the printer.

${ }^{88}$ Edward Channing to Eva G. Moore, July 15 and September 9, 1930, Channing Correspondence, 1884.1930, Houghton Library, Harvard Un1vers1ty, Cambridge, Massachusetts。

89 Morison, "Edward Channing," p. 284. 
According to Channing's daughter, her mother felt that hardening of the arteries led to poor memory, and this in turn led to a marked falling off in the quality of Channing's later work, with wh1ch she was "very displeased." Indeed, in spite of her lack of formal education, Mrs. Channing apparently jolned Miss Moore in checking everything Channing wrote in his later years. 90 She was quite opposed to publication of his seventh volume in the form 1t held at the time of h1s death, as well as to allowing anyone to revise 1 f for publication. She wrote a letter to Brett in March, 1931, which expla1ns the procedure followed:

The manuscript of volume VII has been found to be too incomplete to publish. There has been delay in this decision because I first had to have a photostat copy made, as there was no complete duplicate. Then I asked our two outstanding Professors of American History here, Schlesinger and Morison, to read the copy, and give me their unbiased opinions. Of course all this has taken time. Both Professors independently of one another agree substantially in their verdicts--first that it not only is far from ready for the press but that $1 t$ is not up to the standard of the other volumes--and then that publication of $1 t$ would detract from Mr. Channing's reputation.

Th1s is trag1c after these years of hard labor, but Mr. Channing's powers of work had lessened very much of late and his memory was not certain. For these reasons I felt it imperative to have the advice of experts before communicating with his publ1shers. 91

After discussing briefly the question of providing a general Index for the ser1es, Mrs. Channing became more personal in her analysis:

90 Interviews w1th Elizabeth Channing Fuller, August 18 and 19, 1966, Chatham, Massachusetts.

9lAlice T. Channing (Mrs. Edward Channing) to Brett, March 12, 1931, Macm1lian Collection. 


$$
\text { It } 15 \text { a great disepootntment co me as I am sure }
$$

it is to you that we must give up volume VTT, but

you Nill agree with me 5at Mr. Channing's reputa

tion must be safeguarded. He always emphasized the

fact that it was a mistake to publisi a man's

uníinished work. He also lmpressed upon me that

any incomplete work of his must never be revised

and edited by another.

He was so keen about volume VII and longed so

to finish it, it is heartubreaking。9?

Brett's response to this is unknown, but as a publisher

he must have felt remorse that the volume could act be pub

Iished。 Mrs。Channing wrote a very similar letter to President

Lowell, and received a reply in complete agreement with her

decision. 93 Both Schlesinger and Morison have gone on record as agreeing with her account of the story. Schlesinger felt

"The fact was that in moving beyond the of trodden ground of the period before 1865 channing had shown littie grasp of tre new forces of industrialization ard urbanization which in the century's final years transformed the country." Ie was also careful to point out that "The outcome undoubtedly would have been far different had Channing essayed the volume at the peak of his powers." 94 Morison said Channing"s manuscript definitely showed that he had declined, and, among other things, sald it "went off Into rhapsodies about such figures as James J.H11I

\section{Inid.}

93 Al1ce T. Channing to Lowell, March 11, 1931, and Lowell to Allce T. Channing, March 12, 1931, Lowel1 Papers.

94 Arthur M. Schlesinger, In Retrospect: The H1story of a Historlan (New York: Harcourt, Brace, and World, Incorporated, 1963), p。86. 
and Rockefelier, and compietely le:t ol many lmportant things。" 95

So volume VII was never publisted; indeed, Mrso Cranning apparentiy destroyed tre manus rifto Morison was even in agreement with this action. It was "the only thing to do," he sald, for one evaluating oraning, gr 're basis of thet mandscript would have considered him a secondurate nistorian.96 A second. rate historian Edward Chamring was not; the six volumes a his Great work which were published provide proni enough of thius

$$
95 \text { interview with Samuel Eliot: Morison, June 9, 1967, }
$$
Cambridge, Massachusetus.

90 Tbid。 Channing: a grandsza, Torm Cnaming Eulier, said the ranuscript wi destroved by the timily, apparentiy upon the recommendation of Lawrense Shaw Mayo, whor he des. cribed as "an intimate friend of crarafrg, and as closely associate nith him as anyone." "Fulier, "Eoward Chansing," p. 130) The presens author cur urierstand the reluctance to publish the manuscript, but nou itrongly take issue with the widow Channing, Samuel Eliot Morison, or aryone else who would contend that it is "the only thing to do" to destroy any histor lcal document, winlch migres possibly have any value. And certainiy Channing's comments on the 1855 w 1898 pertod would have been very interesting and valuable, incomplete and imperfect though they apparentiv nere. It also ssems incon. ceivable trat any perceptive redder of such a manuscript would have decided on the basis thereof inat channing was a "secona: rate historian." Would he not instead have declded, as Morlsc:" and Schlesinger themselves did, thet Chaming's ablilties as a histosian were declining with ase? The destruction of the manuscript can only be lamented. Strangely inconsistent with Morison's stand on the destruction of the Channing manuscript is his condemnation of the adopted twin sons of $A$. $B_{\text {. Hart for }}$ their fallure to preserve intact is coliection of materials. And they did not destroy, but simply dispersed, with profit as their mot1ve - Samuel Eliot Morison, "A Memolr and Estimate of Albert Bushneli Hart," Proceedings of the Massachusetts Historia cal Society, LXXVII (January-December., 1965), pp.50"51。 
Here is not only the eminent historlan of the twentieth century rising from glory to glory as the succeeding volumes ot his History of the United

States were acclaimed by the scholars of the world, but also the struggling Channing of an earlier time who knew that it was in him to be one of the foremost American historians of his generation and was deter. mined that his light should shine. It is not surpris Ing that the first item, Town and County Government, is as sound as the last, the sixth volume of the History. But the variety of interest exhlbited in Mr. Channing's minor writings of the 1880 's will probably be a revelation to some of us who knew him only in the twentieth century. A revelation rather than a surprise, for now and then he would astonish his disciples by the breadth of his knowledge Lawrence Shaw Mayo, "Introduction," B1bliography of Edward Channing by George W. Robinson Cambridge: Harvard UnIversity Press, 1932), p。3. 


\section{TEXTBOOKS}

In 1896 I took my family to England for nine months and wrote a high school text book, entitled "A Students' History of" the Unitex States," which took me four months to write and has added greatiy to the comfort of my wife and children. It has also made it possible for me to devote a large portion of the last quarter of a century to the production of a "H1story of the United States."I

Though it was by no means his first publication, the first book-length work which Edward Channing authored alone was a volume in the Cambridge Historical Series entitied simply The United States of America, $1765 * 1865$. It was published in England in 1896. The aim of the series was "to sketoh the his tory of Modern Europe, with tinat of its chief colonies and con quests, from about the end of the fifteenth century down to the present t1me。" It was "Interded for the use of all persons anxious to understand the nature of existing political condi. tlons," and 1.t was hoped that the volumes would "be useful not only to beginners but to students who have aiready acquired some general knowledge of European H1story."? Properly speaking, then, Channing's volume in this series probably was not designed to f1t the normal definition of a "textbook." St111,

${ }^{1}$ Harvard College Class of 1878. Secretary's Report. Number VIII, Fifitieth Anniversary Report, 1928.

${ }^{2}$ Edward Channing, The United States of America, 17651865 (Cambridge: At the University Press, 1896), p。1v。 
because of tts general nature, and because of the relationship

It bore to h1s major text, A Students' H1story of the United

States, it does not seem inappropriate to deal with 1 t as such.

Channing stated in his preface that his aim was "to

trace the steps by which the American people and 1ts peculiar

type of federal state have developed out of such heterogeneous

and unpromising materials for nation-bullding as were to be

found in the English American Colonies in 1760." He had devoted

less space to "campaigns and battles" than was usual, he said,

so that he could give more to "the deeper causes underiying

the American Revolution" and to the period from 1783 to 1817 .

Channing made it clear that his "Bibliographical Note" at the

end of the volume was merely suggestive, rather than indicat-

ing the sources upon which the narrative was founded. The

first six chapters, cover1ng up to 1809, were "based on the

author's own reading of the original sources," while Henry

Adams and James Ford Rhodes were the authors of the most

extensively-used secondary works for the rest of the volume.

And finally, he showed the same awareness of the problem and

Importance of maintalning objectivity which he was later to

show in the Great Work. Not only is it "practically Impossible

to be absolutely accurate in a work of this size, covering

such an extended period and dealing with so many disputed

events," he wrote, but 1t is a.so "sometimes impossible for

an American to appreciate the motives of h1s ' $k$ In beyond sea."

"The utmost that an historical student can do," concluded

Channing, "Is to study and write without malice in h1s 


\section{9}

heart-and this the present writer can fairly claim to have done." 3

In general, The United States of America corresponds With what one would expect, after having read the History, Channing to have written in a book of that size on that period. Two things, however, are rather surprising. For one, Channing proved quite willing, writing for a British audience as he primarily was in this case, to make concessions to the British point of view, particularly, of course, in the Revolutionary era. For example, here we learn that James otis was wrong in his argument against writs of assistance, since Parliament was the supreme legislative body of the emplre and did have the right to issue them; that the Stamp Act was "a fair and eguit. able measure"; that the Boston riots against that measure were "disgraceful"; and so forth. 4

The second surprising thing which comes out of this volume is the fact that Channing changed his mind in his eval. uation of certain things between the time he wrote this and when he wrote his multi-volume series. The coverage of the Mexican War here is certainly no whitewash of the American side; Indeed, we are told that this was a case of "an attack on a weak nation by a strong one." Likew1se, Channing had not yet settled into his later understanding of the causes of the

\footnotetext{
3Ib1d。, pp。vav1。

Ib1d., pp.44,31,49,53。
} 
C1vil War. There was a problem in his assertion, on the one hand, that the material 1nterests of North and South were so different that they led to war-he even criticlzed the leaders of the time for not understanding that this was the "true nature" of the conflict and thus appealing to the Constitution -and his contention, on the other, that consitutional interpretation was at the heart of the conflict. He had made up his mind as to the causes, or rather cause, of the collapse of the Confederacy. It was not loss of morale, but the blockade which "contributed more than any other single thing to the destruction of the Confederacy." Finaliy, Robert E。 Lee was here presented as "the ablest soldier of the war. Indesd, he takes high rank among the foremost military leaders of moderm times." 5

But this is perhaps an unfalr approacho Channing, after all, had not yet written the Great Work as of 1896, and therefore had not done the extensive research whlch led him to the conclusions he was to draw there1n. Anyway, a historian should have the right to change his mind, indeed should be ever ready to do so if the alteration is based on sound evidence. Over all, The United States of America was an excelient littie volume for its time, sound and eminently readable. Only at one point does a different vien between 1.t and the larger work seem more important and difficult to understand. Channing, in

$$
\text { Ibid., pp. 44, 31, 49, 53。 }
$$


the later work, seemed to imply approval of the v1ctory of the forces of union over those of particularism in United States history. Here, however, he noted the decision of the Finst Continental Congress to give each colony one vote in its deliberation as a particularistic tendercy, then went on to point out how most historians had lamented this declsion and emphasized "the evils which have resulted from the state right theories." H1s own conclusion here was that "1t may well be that the salvation of the country has been due to the strong local pride which prevalis among its cltizens and to their dis like of centralization。" 6 The splrit of such a statement, at least, is not in agreement with the nationalistic, Unionist sentiments expressed by Channing at many points in the History. Reviewers received this book very well, basically favor able notices appeared in the Annals of the American Academy of Political and Social Science, Critic, Dial, Athenaeum, and School Review. 7 But the most important review appeared in Br1tain in the Spectator. This publication felt that 1t would "be difficult for any one to approach the treatment of the many controversial 1ssues which are strewn across the perlod dealt with in this book with more entire freedom from prefudice or blas than that shown by 1ts author." This was, indeed, "the

$6_{\text {Ib1d. }}, p p 。 107=108$ 。

7 Herbert Friedenwald, Annals of the American Academy of Political and Soc1al Science, IX (March, 1897), pp.83-84; Cr1tic, XXVIII (May 16, 1896), pp。349-350; DiaI, XXI (October 1, 1896), pp. 193-194; Athenaeum, CIX (May 22, 1897), p。676; and School Review, IV (November, 1896), pp。6 $94-695$. 
prime qualification of a historian." "The second chlef qual1fication of a historian--the power of vivid presentment of the events related--he [Channing] does not seem to us to possess In such large measure." He was "a good plain writer," but no "11terary artist." In conclusion, 1t was "a book which, though not without les defauts de ses qualites, is a distinctiy useful a1d to the study of a subject upon wh1ch every Intelligent Englishman ought to be well informed." 8

The United States of Amer1ca was translated 1nto French, derman, Japanese, and Russian. According to Samuel El1ot Mor1son, Maxim Gork1 once told Channing that the Russian translation "was read aloud in revolutionary gatherings, and helped the good work of undermining the Czarist regime." Desplte al1 th1s, the translations and the accolade of revlewers, the book did not do very well in England; Morison sald that was because "the English w111 not read American h1story unless written by one of themselves." 9 Probably the most important result of 1ta publication was the Invitation it brought to Channing from deorge P. Brett of the Macmilian Company to write a one-volume textbook in United States history. Channing recognized this later himself, for he wrote to Brett in 1903: "I have no great affection for that Cambridge book from which I get very littie

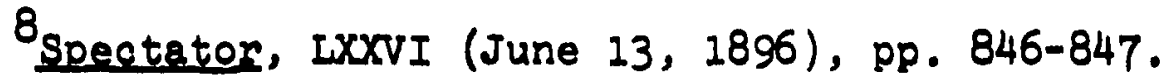

9Samuel El1ot Mor1son, "Edward Channing: A Memo1r," Proceedings of the Magsachusetts H1 tor 1cal Soc1ety, IXIV (October, 1930-June, 1932), p. 271 . 
money--indeed the only really good thing that I have got from It is my pleasant and profitable relations with you, but that is worth a great deal."10

"Worth a great deal" Indeed! The four months Edward Channing spent in England in 1897 writing that textbook were probably the most important of his life. He called the volume A Students' History of the United States. Published by the Macmilian Company in 1898, it "proved to be one of the most successful books of the sort, selling by the tens of thousands, and, in several revised editions, holding 1ts own for thirty years among a host of rivals."ll Channing had serlous doubts about undertaking the project, for he had planned to use his first sabbatical to get started on his projected elght-volume history. He felt "an undercurrent of desire for larger financlal fam1ly resources," on the part of h1s wife, however, and his mentor on the Harvard faculty, Charles F. Dunbar, advised him specifically to write the book. Also, he was doubtless Influenced by the proposed contract, which, he sa1d, offered royalties so generous as to "make most school book publishers blush w1th shame."12 Surely he was never sorry about his dec1sion to do 1t; the only 111 effect was writer's cramp. It is

10 Edward Chann1ng to George P. Brett, March 6, 1903, Edward Channing File, Macmilian Authors Collection, New York Public Library.

11Morison, "Edward Channing," p. 274.

$12_{\text {Edward Channing, "The Recollections of a Hitherto }}$ Truthful Man," (manuscript in possession of Elizabeth Channing Fuller, Chatham, Massachusetts), p. 38 。 
hardly an exaggeration to say that the Student's H1story made the Qreat Work possible.

As became a hab1t with Channing, once he made up his mind to write a text, he wasted no time. On January 21, 1896, he informed Brett that he had "had some 1dea of preparing" a high school text, but "the matter has not yet taken shape in my mind." Less than two months later, on March 16, he wrote a six-page letter outlining in detall almost exactly the way the Students' H1story turned out. The text was to be designed for "the upper classes in High Schools, the lower classes in the Normal Schools, and the lower classes in the less advanced colleges." It was to emphasize "three IInes of development: const1tutional, Industrial, and soc1al." The length should be between flve and $s 1 x$ hundred pages, including maps and 111ustrations and "top1cs and references." 13

The Students' H1stony was an interesting, well-written text, better by far than many of today's books used at the same leve1s. Of particular interest here, since they were topics not covered in Channing's later work, is the "Introduction," actually a full-length chapter on "The Land and 1ts Resources," and that portion covering the years after 1865. In the introductory chapter, Channing stated that "Students of history and geography have long been agreed that, within certain I1mitations as to rainfall and temperature, the physical formation of a

13 Channing to Brett, January 21 and March 16, 1896, Macmillan Collection. 
country, the character of its solis, and the extent and variety of 1ts mineral deposits exercise a declsive influence on the Iife of the people whlch 1nhablts $1 t_{0} " 14$ The chapter, then, is actually an excellent brief description of the geograph1cal setting of American history.

In the Students' History, Channing was naturally much less interpretative than in the Great Work--because he had less space, because it was a textbook, and, on the post-C1vil War years, because he was dealing with relatively recent events. It would have been interesting indeed to see the evaluations he placed upon people and events in the years after 1865 in the manuscript for the seventh volume of his H1story! The coverage in the Students' History is a poor subst1tute. Channing did show a good deal of foresight occasionaliy. For example, he did not say, as historlans have tended to since, that the Span1sh-American War marked the rise of the Unlted States to world power status, but he knew already, at least as early as 1910, that this had come in that perlod. He associated it specifically with the Boxer Rebellion in China in 1900:

It marks the entrance of the United States Into the arena as a World Power and the breaklng down of that policy of isolation which was dear to Washington and to Jefferson; but it 18 very poss1ble that if these great men were now living, they would view the matter very differently from what they did one hundred and more years ago. 15

${ }^{14}$ Edward Channing, A Students ' H1story of the United States (New York: The Macmillan Company, 1898), po 11 . ${ }^{15}$ Ibid., "New Edition, with Additions," 1910, p. 582. 
A little can be discerned from sources other than the Students. H1story as to how Channing felt about certain things In the post-1865 per1od. Two places in print Channing sa1d things which 1ndicate something of his view of the Reconstruction era. Of the closing scene at Appomattox, involving the men of the armies of Northern Virginia and the Potomac, he wrote: "Well would 1 t have been had the reconstruction of Southern soclety been in the hands of these men and of others who respected one another and were guided by Abraham L1ncoin." After quoting approvingly from Lincoln's second inaugural address, Channing concluded: "S1X weeks later.ooan assassin's bullet closed the life of th1s greatest of Amerlcans and dellvered the Southern people Into the hands of the Radical Republican politiclans of the North."16 At the same point of the story in The United States of America, Channing carried this 1dea a little farther. "Thus perished the one man able and willing to restrain the Northern extremists," he wrote of Lincoln's assassination. "The 'reconstruction' of the Union fell Into less capable hands, and many of the later woes of the South may be regarded as in part due to this most unholy of murders." 17

Even in the Students' H1story, Channing had hinted at his view of one major 1ssue of the 1865-1900 perlod by referring

\footnotetext{
${ }^{16}$ Edward Channing, A History of the United States. Volume VI: The War for Southern Independence (New York: The Macmilian Company, 1925), pp。635-636。

17 Channing, The United States of America, p. 292 .
} 
to "the scheme of civ1l service reform."18 In the History he stated 1 more forcefully:

of late years, [written in 1925] the building up of a bureaucracy, under the guise of c1v1l service reform, has tended to cast reproach upon the earlier Presidents. It is not at all certaln, however, that the clvil service under John Quincy Adams or Andrew Jackson, in the second year of his administration, or James Buchanan, was any more inefficient than it has been under the bureaucratic system that has necessarily developed w1th c1v1l service reform.19

In a letter to James Ford Rhodes in 1919, Channing expressed a low view of two of the leading politiclans of the "Gilded Age." "I have been reading your new volume and have been much interested in your estimates of men and things," he wrote. "We all grow klndly as we advance in years; but have you not been a little mite too gentle with Blaine and Carfield -I find it difficult to understand how the latter ever gained so great a reputation." 20

One of the most interesting, but rambling and somewhat b1tter, letters Channing ever wrote was to Brett in 1912. What set it off is unclear, but it is perfectly obvious that Channing was upset. The letter was handwritten and labeled "Confident1al." Here are significant excerpts:

The Kansas City Star or some other paper says that we have a constitution made by generais +

${ }^{28}$ Channing, Students' H1story, 1910 ed., p. 551.

19 History, VI, p. 124 .

20 Edward Channing to James Ford Rhodes, October 29 , 1919, James Ford Rhodes Papers, Manuscript Division, Library of Congress, Washington, D. C. 
statesmen who died one hundred years or more ago-let us have one made up by up-to-date live Americans. Here they are:--

Dead Gens + statesmen Washington

Frankin

Jefferson

Madison

Hamilton
Live colonels + T. R。 Gifford Pinchot Lafollette J. A. Garfield Dixon
Others

Wey 1

Simons

Debs

Gompers

Haywood

I take my chance with the deceased. Serlously these men of the second [column] fail to understand that the Constitution of the United States is buttressed on the Common Law--the old Anglo Saxon Law. They want to subst1tute for 1 the 1deas of theorists on human rights--and they cannot do it unt11 they shut up the law schools + k1ll the lawyers-and drive out of the American conscience respect for "The Law." When they do that there will be the dev1l to pay。

I agree w1th you that it is nonsense to educate everyone to be a university professor--teach the mass of the people commerclal expertness. Let them work + let the lawyers and professors rule. That is what it amounts to t being a professor I am with you, 21

Channing knew he was getting a b1t carried away; a later paragraph read: "I know that you abhor my hand writing or I would go on + tell you about politics. I had faith in man once."22

The reviews of the Students H1story doubtless helped It to 1ts great success, for they gave it almost universal acclaim. A. A. Freeman, for example, in the American Historical Review, ha1led it as "decidedly the best one-volume Amer1can history yet published." 23

${ }^{21}$ Channing to Brett, March 9, 1912, Macmilian Collection. 22 Ib1d.

23 A. A. Freeman, American H1storical Rev1ew, III (April, 1898), p. 544. Other reviews were: Hugh E。 Egerton, Engl1sh H1storlcal Review, XIII (October, 1898); Nation, (March 17, 1898), pp. 211-212; John W11l1am Perr1n, Yale Rev1ew, VIII 
Another thing which must have helped sales for the text was Channing's constant striving to please the public. He once sald the two essential requirements for a school history text were "careful selection of important events and their narrative in a direct, simple, but not childish style。" He also strongly condemned several texts for romanticizing such events as the landing of the Pligrims and the signing of the Declaration of Independence. ${ }^{24}$ But Channing was more than willing to suppress his own debunking inclinations for his textbooks. "I Intend to use IIncoln as frontisplece and to say nothing to stir up the G. A. R。," he wrote to Brett just before publication of the Students' H1story; "we have no portralts of southern generals to which they have always objected." "I suggested Tilden to placate the Dems, who w111 not like some of my tariff remarks," he wrote in another place; "as you think $1 t$ w111 unduly Irritate the Republicans I have" decided to omlt 1t. And st1ll again, "If any good Cathollc or any one else except an 'unreconstructed' person has alleged aught against e1ther book [the Students. H1story and another text] kIndly have me informed that I may redress the grievance." Note the

(August, 1899), pp. 219-220; and Franc1s $W_{\text {. Shepardson, School }}$ Rev1ew, VII (March, 1899), pp.186-187. Also, these four reviews of the third revised edition: Chautauquan, LXXII (January 10, 1914), p. 382. Educational Rey1ew, XLVII (January, 1914), p. 97; Independent, LXXIX (August 17, 1914), p. 250; and Nation, LXLVIII (May 7, 1914), pp.548-549.

24 Edward Channing, "Some Recent School Books," Magazine of Amer1can H1story, XIII (February, 1885), pp.185-186. 
lack of concern about the South; even this changed. The cover of the Students' H1story was originally designed with "colors as near as binding cloth w1ll go of the blouse and breeches of the Union soldiers of the Civil War." Later: "From what I have heard the objection to the book in the South is mainiy based on the cover; and that we propose to obviate by putting 1t into a new dress." 25

Whatever the reasons, the Students' H1story went through four major revisions, in 1904, 1913, 1919, and 1924, and many printings in between, which sometimes included minor changes and corrections. ${ }^{26}$ Channing was apparently surprised by this success. "The cordial welcome and continued favor wh1ch have been accorded to this advanced manual of United States history have been far in excess of the author's expectations," 27 was a statement he included in the preface to all the later editions. But he was always duly aware of and grateful for the success also. In 1927, when he knew the book was on the way out, he wrote to Brett: "It has had a good run and has been a profitable venture for us both,--and I think every year that I owe you a debt of gratitude for suggesting to me that I should write $1 t_{0} " 28$

${ }^{25}$ Channing to Brett, July 7 and 13, 1897, February 15, 1901 , December 26,1897, and February 15 1904, Macmilian Collection.

26 George W. Robinson, Bibliography of Edward Channing (Cambridge: Harvard Univers1ty Press, 1932), pp.13-14.

27 Channing, Students' H1story, 1910 ed., p.v11. 28 Channing to Brett, August 3, 1927, Macmillan Collection. 
On the bas1s of the success of the Students ' H1story, Channing wrote three other American history texts for various levels. They were not nearly so successful. He also wrote an English history text which was h1s least successful--and poorest. Channing's second textbook effort came only two years after h1s first; A Short H1story of the United States for School Use was published by Macmilian in 1900. Little need be sald of 1t except that it was merely a shorter version of the Students' H1story, designed for grammar schools, and 1t did not do very well. Channing first mentioned the 1dea of "an elementary work for use in grammar grades" in his correspondence with Brett on December 22, 1897; he had 1t written by August 25, 1899. It was published in 1900; by 1904 Channing was already admitting that the book had "not won 1ts place" and "shows clearly that It is not constructed to meet the demand."29 The one review found of the short H1story took the form of a "l1st of shortcomings" and Indicated "the direction in which Prof. Channing should revise his work." 30 The educational department of Macmilian Informed President Brett in 1908 that 1t could not "offer sufficient suggestions" to warrant revision. "We think an entirely new book should be written." 31 A new edition,

\footnotetext{
29 In1d., December 22, 1897, August 25, 1899, and January 27,1904 .

30 Athenaeum. I (January 5, 1901), p. 12.

${ }^{31}$ F. F. Hammond to Brett, October 8, 1908, Macmilian Collection.
} 
revised in consultation with a Miss Susan J。Ginn, did appear the following year; ${ }^{32}$ but after that it was dropped.

After three years, Channing had st1ll another United

States history text on the market. It was called First Lessons In United States History and was published by Macmilian in 1903. As the title makes clear, 1t was designed for beginners In the subject; Channing once sald it was for children from seven to nine years old. He also sald, in his letter to Brett outlining the project, that 1 was "to be chlldilke and blographical, anecdotal and replete in folklore." When he finlshed the manuscript, he wrote Brett that he was anxious to get it in print as he had no duplicate copy. "I have never troubled myself about a manuscript before," he wrote, "but this one seems very precious-mpossibly because it is so worthless." 33 In spite of these comments, Channing was actually quite proud of the l1ttle volume. "It was designed for the small fry," he wrote in 1917, "but has proved to be of use to visiting European professors and lecturers in the Lowell Institute, who absorb 1t bodily and pour out little anecdotes about Franklin, Washington, and Lincoln to their admiring hosts and hostesses on Beacon Street and elsewhere."34 And he wrote to Brett in 1927, when First Lessons was finaliy about to go out of print,

32 Robinson, Bibliography, p. 15.

33 Channing to Brett, February 21, 1901, and October 1, 1902, Ib1d.

${ }^{34}$ Harvard College Class of 1878: Secretary's Report, No. VII, $1917, \mathrm{p} .13$. 
that he was "really sorry about the threatened disappearance." "I have always been very fond of that little book and it has always greatly pleased the small boys and girls to whom I have given 1t." 35 For showing the nature of the book 1tself, one of the little "Do Not Forget" sections included at the end of each chapter is sufficlent, this from the chapter on George Wash1ngton:

DO NOT FORGET

1. Washington's early life and training fitted him to be a soldier.

2. He taught himself good manners.

3. He was grave or gay as the occasion demanded. 36

Channing's last effort in the American history textbook fleld was written in consultation with the same Miss Ginn who alded him in the revision of his Short History. It was pubIlshed by Macmilian, in 1910, and was entitled Elements of Un1ted States History. Channing probably wrote th1s volume because of the lack of success of the Short H1story; it was more elementary, but seems to have been designed for baslcally the same purpose. He signed the contract for it in october, 1908; 1t was written by 4:16 p.m. on September 2, 1909, when Channing wrote to Brett: "I have th1s moment finlshed the flrst draft of the 'Book of Lles' otherwlse known as Channing's 'Elements of Un1ted States H1story.'" Later he wrote: "I

\footnotetext{
35 Channing to Brett, August 3, 1927, Macmillan Collection.

36 Edward Channing, F1rst Lessons in Un1ted States H1story (New York: The Macmillan Company, 1903), p. 78.
} 
think that we have given you a first rate book for second rate grammar schools."37 This text apparently rever aid very inell either, for It was never revised and seldom sppears in Channing's correspondence.

Actualiy Channing's first textbook in point of time was English History for American Readers, published in 1893 by Longmans, Green and Company. Channing was the co-author with h1s relative, Thomas Wentworth Higginson. The book, under the new title of Engl1sh History for Americans, was reprinted in 1894 and revised in 1902 and 1914.38 How 1t survived that 1 ong Is difficult to understind; it was one of the poorest pieces of work to which Edward Channing ever attached his name. It was actualiy a rather elementary English history text in which the "for American Readers" of the title was frequently forgotten. The authors did not even succeed often in their stated objective of treating at greater length those developments in English history which were of particular importance to America, and certainly they did not make any attempt to show English Institutions being planted in and modified in America, nor did they deal extensively or meaningfully with relations between England and America. In conclusion, if not for the authors' reminders in a couple of places, the reader could go through

37 Channing to Brett, October 20, 1908, september 2, 1909, and June 13, 1910, Macmilian Collection.

38 Rob1nson, B1bl10graphy, p. 12 。 
the ent1re volume, unaware of 1 ts titie, and never guess that it was anything other than a rather mediocre "English H1story."

All reviewers had criticlsms of the book, but two gave 1t the panning it deserved. The Critic felt the most obvious weakness was "the one that the very title suggests," $1_{e} e_{e}$, that the authors "hold an ent1rely erroneous view of the functions of history." The Crit1c also sa1d "1t is thus with regret that we see the name of a professor in our oldest college on the title-page of a book concelved in so unscientific a sp1r1t."39 The Cathol1c World surpassed even that. "The Intellect of America would appear to be in a very immature state, in the view of the authors of the new work, English History for American Readers," it began. Th1s reviewer thought the style of narrative bore "a remarkable resemblance to that adopted in such favorite romances as Jack the Giant-K1ller and History of Old Mother Hubbard." He also referred to the "slipshod style," "slovenliness in statement of fact," "careless" ness," and "gross and unpardonable misstatements." H1s conclusion: "History, at 1ts best, is generally only a revelation of half the truth about anything; in such compressions and distortions of 1 t as these under notice, the densest 1gnorance about it is a state more preferable than the sort of knowledge derivable from such a source."40 All told, the Channing

\section{${ }^{39}$ Crit1c, XXIII (November 18, 1893), pp. 315-316. ${ }^{40}$ Catholic Worid, LVIII (November, 1893), pp. 282-286.} Other reviews were: Athenaeum, CIII (June 9, 1894), pp.739- 
admirer can only assume that H1gginson did most of the work on this volume.

Edward Channing, then, wrote one textbook of which he could well be proud-- two if The United States of America is cons1dered a text. A Students' History of the United States succeeded because 1 t was an outstanding book. But he wrote four others that, if they do not detract from his reputation, certalnly add nothing to his stature as a historian. 
CHAPTER X

\title{
MISCELLANEOUS WRITINGS
}

\begin{abstract}
There is something enduring about bibliography of h1gh quality even after it has been outmoded and replaced. One of Channing's and Hart's former graduate students, Carl Russell Fish, who pald tribute to the Guide of 1896 thirty-five years later, declared that "...timeliness was more important than perfection, and few books stand in so significant a relationship to any scientific study as does this to the development of research and teaching in American history."
\end{abstract}

In 1883, the budding historlan Edward Channing was trying to get both his teaching and writing careers off to a good start. He wrote to Wendell Phlllips Garrison of the Nation in January that he was "very anxious to write as much as possible, and I hope that the enclosed [book review] w11l encourage you to send me something more. It is my first attempt to write a review 'out of a book," he continued, "and I hope you w1II bear this in mind in judging of my capabilities." In February he sent this publication a "voluntary offering" to try to get them to call on him for further writing chores. 2 Hardly the confldent Channing of later years! After 1883, However, Channing's list of publications expanded rapidly. In 1884 , he published the Toppan Prize-

${ }^{I}$ Lester J. Cappon, "Channing and Hart: Partners in B1bliography," New England Quarterly, XXIX (September, 1956), p. 340 .

2 Edward Channing to Wendell Phillips Garrison, January 10 and February 12, 1883, Fields and Garrison Collection, Manuscript Division, Library of Congress, Washington, D. C. 


\section{8}

winning essay on Town and County Government in the English Colonies of North America, plus two articles in Science, and the Encyclopedia Britannica's entry on the American colonies. In 1885, twelve 1tems appeared in print under Channing's name, mostly articles in the Magazine of American H1story and Sclence and brief "remarks" on various subjects in the Proceedings of the Massachusetts Historical Society. Only five were added in 1886, but two of these were more sign1f1cant: The Narragansett Planters in the same Johns Hopkins series as Town and County Government and a chapter on "The Companions of Columbus" in Justin Winsor's Narrat1ve and Crit1cal H1story of America. And thus it continued, unt1l Channing's b1bliography at the time of his death consisted of approximately sixteen books and sixty-four miscelianeous publications, including articles, book reviews, etc。

The books, in addition to the Great Work and texts, were the famous Channing and Hart-oor, after the 1912 revision, Channing, Hart, and Turner--Gu1de to the Study of American H1story, The Jeffersonian System in the American Nation series, The Story of the Great Lakes by Channing and Marion Florence Lansing, and The Barrington-Bernard Correspondence, a work edited by Channing and Archibald Cary Cool1dge.

By far the most important of these was the Quide. The original edition was published in 1896 by Ginn and Company. It was divided into three main parts: "Methods and Materials," "Toples and References in Colonial H1story," and "Top1cs and References in United States History." Channing and Hart gave 
no indication as to which of them was most responsible for any particular part. However, in the "Rev1sed and Augmented Ed1t1on" of 1912, wh1ch added Turner to the authorshlp and broadened the t1tle to Guide to the Study and Reading of American H1story, they did do so. Channing was primarily responsible for the "Classifled Bibliography," Included as a part of the "Methods and Materials" section in the first edition, and the section of topics and references on "Colonial History and the Revolution." Thus these are probably the portions on which he concentrated in the earlier edition also. "Methods and Mater1als" discussed the content of American history, 1ts status in schools, teaching methods, and libraries. It also included the general bibliography of American h1story. In the two "top1cs and references" sections, there was a "Summary" of each topic followed by references under these headings: "General," "Spec1al," "Sources," and "B1bl1ography。"

The 1912 Quide was much the same. "Methods and Mater1als" of the old edition now became three parts: "Status and Methods," "Classifled Blbllography," and "Teaching and Reading H1story." A new section of topics and references was added, on the 1865-1910 period. Th1s was Turner's work, as were the additions on the West throughout the volume.

Many have tended to give Hart more credlt than Channing for the original quide. Lester $J$. Cappon, for example, wrote that "From the scanty evidence extant 1t appears that Hart first developed a concrete plan for the kind of book, approximately, that the Guide became, and that in the course of his 
preparation he proposed that Channing collaborate with him。" Cappon also stated that in the manuals Hart used in his courses one could see the Gulde "In embryo."3 Cappon should have pointed out, however, that Channing too had done such manuals. In 1893, for example, he had printed a little booklet entitled Top1cs and References in American H1story, $1492-1783$ for use In his courses that fall; its format was exactly that of the blbllographical portions of the Guide. ${ }^{4}$ Cappon himself admltted that Channing's role was probably more important overall, even if Hart had la1d the foundation, for he wrote that "It was clearly Channing's feeling for consistency of presentation and met1culous attention to stylistic detalis that assured super for results in form and structure." In another place, however, Cappon speculated that the Guide "might appropriately have been published as Hart and Channing, rather than the reverse," but went on, "but the latter's primacy, which he Insisted upon at the outset, was earned, in a sense, by the t1me he devoted to matters of deta11, thus assuring that the form would match the content in excellence." 5

The quide recelved extensive praise from reviewers. "If there has ever been printed a duodecimo volume more useful than this to the student and the teacher of American history,"

${ }^{3}$ Cappon, "Channing and Hart," pp. 327-328, 324.

${ }^{4}$ Edward Channing, Toplcs and References in American H1story, 1492-1783 (Cambridge: Edward W。 Wheeler, Printer, 1893)。

${ }^{5}$ Cappon, "Channing and Hart," pp.335, 339。 
exulted the American Historical Review, "It is not known to the present reviewer." 6 Historians have praised the Guide ever since. Harry Elmer Barnes, in A History of Historical Writing, referred to it as "the authoritative guide to the writings on American history." $\mathrm{H}$. Hale Bellott, in American History and American Historlans, considered it the "indispensable handbook of all students of American history." Samuel Eliot Morison, in a tribute to Hart, noted that the Guide "had an immense influ= ence throughout the United States at a period when the teaching and study of American history were rapidly expanding."7 The greatest tribute of all came in 1954 with the appearance of the Harvard Guide to American History, which 1ncluded this inscription on a dedication page:

6 American Historlcal Review, II (January, 1897), p。357。 The review was unsigned, but was probably written by the ed1tor, J. Franklin Jameson. Two other reviews were: Nation, LXIII (November 16, 1896), p。 409; and Bernard C. steiner, Annals of the American Academy of Pol1tical and Soc1al science, IX (March, 1897), pp. 84-87. Two reviews of the 1912 edition were: A. Lo A. Booki1st, IX (Apr11, 1913), p. 349; and Marcus W. Jernegan, American Histor 1ca1 Rev1ew, XVIII (April, 1913), pp. 589-592. Jernegan reviewed the volume quite criticaliy, noting several errors and omissions. His concluding paragraph shows the tone of the review: "Much might be said of the excellencles of the book but these are well known through the w1de use of the first edition. It is of course not only the best, but an indispensable manual for the student of American history, and contains an enormous amount of material skilifully arranged. It does not, however, rise to the highest standards of scholarsh1p, though one would expect authors of such high reputation to put out a more perfect book, especialiy in a revised edition." (pp. 591-592)

7 Harry Elmer Barnes, A H1story of H1stor1cal Writ1ng (Norman: University of Oklahoma Press, 1937), p. 398; Ho Hale Bellott, American History and American Historians: A Review of Recent contributions to the Interpretation of the History of the United States (Norman: University of Oklahoma Press, 
$\therefore$ TO THE MEMORY OF

EDWAFD CHANNING

ALBERT BUSHNELL HART

FREDERICK JACKSON TUBNER

WHO BLAZED THE WAYO

Besides this, the authors of th1s 1954 Gu1de, Oscar Handin, Arthur Meler Schlesinger, Samuel Ellot Morison, Frederick Merk, Arthur Meler Schlesinger, Jr。, and Paul Herman Buck, which many conslder the most valuable single blbllographical ald in American history today, pald tribute by acknowledging that their work "In 1ts main outlines follows that of Channing, Hart, and Turner." 9

The next most important of Channing's miscellaneous books after the Gu1de was The Jefifersonian System, 1801-1811. It was pub11shed by Harper and Brothers in 1906 as volume XII of Hart's series, The American Nation: A H1story. The 200 pages In the Great Work devoted to Jefferson were far superior to the 300 in The Jeffersonian System. Probably the major reason for this is the greater amount of research Channing had done by the time he wrote the fourth volume of his History in 1917. In 1906 he had done very little in the original sources,

1952), p. 22; Samuel El1ot Morison, "A Memo1r and Estimate of Albert Bushnell Hart," Proceedings of the Massachusetts Histor1caI Soc1ety, IXXXVII (January-December, 1965), p. 40. 8 oscar Handiln, Arthur Meler Schlesinger, Samuel Ellot Mor1son, Freder1ck Merk, Arthur Meler Schles1nger, Jr。, Paul Herman Buck, Harvard Guide to American History (Cambridge: The Belknap Press of Harvard Un1versity Press, 1954).

${ }^{9}$ Ib1d., p. v111. 
acknowledging in his preface that Henry Adams' "masterplece," H1story of the United States of America during the Administrations of Jefferson and Mad1son, was the "foundation" of h1s Jefferson volume. 10

Channing himself apparently did not have a very high opinion of this book. He proposed "to do the job as a potboller," secondary to his own volumes, and to do 1 t at all only because of the money and the necessity of getting along with Hart. Some of the flaws of the volume Channlng would doubtless have admitted, but would have attributed most of them to Hart's editing. He once noted some "curlous omissions" in John Spencer Bassett's volume in the American Nation series, then continued, "but having also written a number 1s that same series, I am not at all certain whether this eccentricity should be charged to him or to the editor."11

Hart's American Nation series as a whole has, of course, been highly regarded by historians. Morison has written that the Importance of the set lies in the fact that "1t was the first general presentation of the subject by the group of professional historians of the United States that had grown up

${ }^{10}$ Edward Channing, The Jeffersonian System, 1801-1811 (New York: Harper and Brothers, 1906), poxi11.

${ }^{11}$ Edward Channing to George P. Brett [President, Macmilian Company], January 21, 1902, and October 10, 1906, Edward Channing File, Macmilian Authors Collect1on, New York Public Library. 
In the previous twenty-five years."12 Max Farrand, reviewing the entire series for the American Historical Review after all volumes had been published, noted that the speclalist had usually been disappointed with the volumes in his fleld but pleased w1th the others, wh1le the layman had been enthuslast1c about them all. The first fifteen volumes were considered better than the other twelve--The Jeffersonian System was the twelfth volume-mbut 1 was also noted that "the series as a whole has achleved a somewhat surprising degree of excellence both in readableness and in accuracy." The conclusion, perceptive considering the time 1 t was written, was that the series was not an "epoch-making" work so much as 1t was an "epochmarking" one. "Save for an occaslonal exception, the volumes represent the end of the old and not the beginning of the new history that is being studied and written."13

All told, then, The Jeffersonian System was not one of Channing's outstanding works, but ne1ther was it one of h1s worst. Indeed, it was rather good, and an effort of which he could well have been proud, if for no other reason than that 1t was a part of the memorable American Nation series. Channing was producing major volumes at a rapid pace in the years 1905 to 1910. In 1905 the flrst volume of h1s

12 Samuel Ellot Mor1son, "Albert Bushnell Hart, 18891939," Proceedings of the Massachusetts Historical Society, IXVI (october, 1936-May, 1941), p. 437.

13 Max Farrand, American Historical Review, XIII (Apri1, 1908), pp. 592-595. 
History appeared, in 1906 the Jefferson volume, and in 1908 volume II of the H1story. On December 5, 1908, Channing wrote to Macmillan's President Brett that the manuscript of "the Great Lakes" was ready. "I think that it is a good book," he added. 14 He was referring to what became The Story of the Great Lakes by Edward Channing and Marion Florence Lansing, published by that company in 1909. The volume was divided Into three parts, "D1scovery and Exploration," "The Struggle for Possession," and "Occupation and Development." "A Brief L1st of Books" was added at the end. The Great Lakes is actual1y quite elementary in nature: there are no footnotes nor end-of-chapter bibliographical notes, only the brief list of books, which is just that; there is virtually no interpretation of events; and nearly all of the factual material, except for the personal travel narratives, could have been taken from the appropriate portions of the H1story so far as extensiveness of coverage is concerned.

The D1al heaped praise upon The Great Lakes, and basically favorable reviews also appeared in the New York Times, the A. L. A. Bookl1st, the Literary D1gest, and the Nat1on. ${ }^{15}$ But, more 1mportantly, the book recelved a highly crltical notlce in

${ }^{14}$ Channing to Brett, December 5, 1908, Macmillan Collection.

15Lawrence J. Burpee, D1al, XIVII (July 16, 1909), pp. 45-46; New York T1mes, May 8, 1909, p. 290; A. L. A. Bookl1st, $V$ (May, 1909), p. 133; L1terary D1gest, XXXVIII (May 22,1909 ), pp. 898-899; and Nat1on, LXXXIX (JuIy 8, 1909), pp. 36-37. Two reviews were non-committal: Independent, LXV (June 3, i909), pp. 1239-1241; and American Rev1ew of Rev1ews, XXXIX (May, 1909), p. 639. 
the American Historical Review. Furthermore, the comments appeared under "Minor Notices," no compliment 1tself. The title, wrote this reviewer, was a misnomer, for the book was "less the story of the Great Lakes than chapters from the history of the regions contiguous to the lakes." Even the selection of "chapters" was not very well done, for the story of Lincoln and Douglas in Chicago "has about as much to do with the story of the Great Lakes as 1 t has with the story of Barnegat." The book was, "for the most part, a pleasant retelling of facts familiar to the student and long accessible in works of established repute." "The adequate history of the Great Lakes," concluded the reviewer, "is yet to be written."16 The Story of the Great Lakes holds the same position in Edward Channing's bibllography as English History for the American Reader. Fortunately, once again, there is a co-author on whom much of the responsibility can be placed.

Channing's name appeared in connection with one other book, of which he was co-editor with Arch1bald Cary Coolidge. Published in 1912 as a volume in the Harvard Hiatorical Studies under the title The Barrington-Bernard Correspondence and Ilustrative Matter, 1760-1770, it consisted of selections from the papers of S1r Francis Bernard, a colonial governor of both New Jersey and Massachusetts. These were a part of the origInal manuscripts collected by Jared Sparks and left to the

\footnotetext{
p. 189 .

${ }^{16}$ Amer1can H1stor1cal Rev1ew, XV (October, 1909),
} 
Harvard Library. 17 Lord Barrington was a cousin of Bernard's wife and holder at various times of such important positions as Chancellor of the Exchequer and Secretary at War. Much of the correspondence was between Barrington and Bernard, and thus the importance of the letters, according to the editors' introduction, lies in "the fact that they are friendly and confidential epistles and not officlal letters, although they were written by two of the most highly placed government off1cers in England and in America." 18 Their major 1mportance to Channing was the fact that he was able to use them to good advantage in the third volume of his Great Work. ${ }^{19}$

Morison has stated that Hart was "the only person who extorted a volume from Channing after the latter started his History of the United States. "20 This, of course, is an

17 A letter from Channing to Harvard President $A$. Lawrence LoweII, dated April 27,1910 , inquiring as to the efflcacy of pubilcation of a volume of these materials, in view of the restrictions in Sparks' w111, is in the Edward Channing folder, A. Lawrence Lowell Papers, Harvard UnIvers1ty Archives, Cambridge, Massachusetts.

18 Edward Channing and Archibald Cary Coolidge, eds., The Barrington-Bernard Correspondence and Illustrative Matter, 1760-1770 (Cambridge: Harvard Un1vers1ty Press, 1912), p. v11.

${ }^{19}$ See, for example, Edward Channing, A History of the Unlted States, Volume III: The American Revolut1on, 176I1789 (New York: The Macmillan Company, 1912), pp. 58, 59, 89. The one review found of this volume was almost completely descriptive and non-committal, only criticlaing the editors mildly at one point for being too critical of Barrington.-George Louls Beer, American Historical Review, XVIII (Juiy, 1913), pp. 816-818.

20 Mor1son, "Albert Bushnell Hart, 1889-1939," p. 438. 
exaggeration, for in addition to The Jeffersonian System of which Mor1son spoke, Channing published the Barrington-Bernard Correspondence, The Great Lakes, and several textbooks all after the first volume of the History was published in 1905. St111, it is true that he concentrated on the Great Work, and that this led to a decreased output of not only other books but of miscellaneous shorter publications as well.

Before 1905, Channing had produced a s1gnificant amount of such work, and, although not major, it deserves attention. The flrst entry in h1s personal b1bl1ography, dated 1884, was the Toppan Prize-winning essay on Town and County Qovernment In the English Colonies of North America, a volume in the Johns Hopkins University Studies in Historlcal and Political Sclence, edited by Herbert B. Adams. ${ }^{21}$ Interestingly, Channing stated that this was "written under the stimulus derived from" Adams' own contribution to the series, on the Germanic origins of New England towns. 22 Th1s is especially interesting because of the fact that Channing's conclusions differed rather algniflcantly from those of Adams. The difference was even greater in a follow-up on Channing's part in the form of "A Few Remarks on the Or1gin of New England Towns" made before the Massachusetts H1storical Soclety in 1892.

Here he sald he could not accept Adams' "Qerman1c theory." It seemed to h1m that "the advocates of the Germanic

$$
\begin{aligned}
& 21_{\text {Baltimore: N. Murray, } 1884 .} \\
& 22 \text { Ib1d., p. } 5 .
\end{aligned}
$$


origin of New England towns have pushed the theory of the continulty of history farther than the facts in the case w111 bear." "Perhaps the germs of our local 1nst1tutions may all be found some time in those old communities living in the German forests so long ago," Channing thought, "but they have not yet been found there." He insisted he was not trying to disprove the theory, but simply contending that it was nothing more than a "working hypothes1s," unproven, and therefore "a very poor basis on which to bulld an elaborate superstructure." He could still go no further than to assert, as he had in the Johns Hopkins volume, that "both the Southern parlsh and the New England town were 'survivals' of the English Common Law parish of 1600.123

Paul H. Buck was correct in referring to Channing's Town and County Qovernment as "a f1rst-rate plece of scholarship for 1ts time."24 In 1886, another brief work of Channing's was published in the same series. It was entitled The Narragansett Planters: A Study in Causes, and was a description of the unique, for New England, landed artistocracy of stock farmers and da1ry men in the southern part of what became Rhode Island. 25

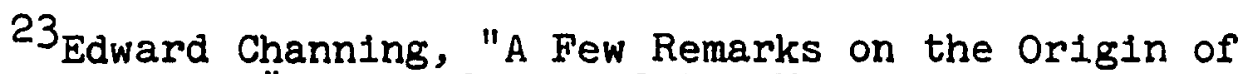
New England Towns," Proceedings of the Massachusetts Historical Society, III (1891-1892), pp. 243-244, 245, 247, 251. 24 Interview with PauI H. Buck, June 9, 1967, Cambridge, Massachusetts.

25 Balt1more: N. Murray, 1886. 
In 1885 , Channing wrote a brief note on "The Sackv1lle Papers" for the Magazine of Amer1can H1story. He thought the collection deserved "the careful attention of the future h1storian of the American Revolution," 26 and made good use of the material himself in his volume on that perlod. 27 In 1886, he contributed the f1rst of two chapters to Justin W1nsor's elghtvolume predecessor of the American Nation serles, the Narrative and Critical History of Amer1ca. Th1s was in the second volume, and dealt with "The Companions of Columbus," actually a brief history of Spanish Caribbean exploration in the period 1498 to 1519. Channing's second contribution to the set came in 1887 in volume VI and was entitled "The War in the Southern Department." It was a more thorough coverage of the Revolutionary war in the South than his later H1story had the space to give. Both these chapters, as w1th the Narrative and Critical H1story in general, were detalled, factual, largely non-1nterpretive, essays with extensive bibliographles. 28 As W1lliam A. Dunning

${ }^{26}$ Edward Channing, "The Sackv1lle Papers;" Magazine of American H1story, XIII' (June, 1885), pp. 490-491.

27 See, for example, H1story, III, pp. 137, 249, 253. 28 Justin w1nsor, ed., Narrative and Crit1cal History of America, II (Boston: Houghton, Miffiln and Company, 1886), pp. 187-216; and III (1887), pp. 469-555. Channing also a1ded winsor in an appendix to volume VII (1888) ent1tled "Territorial Acquisitions and Divisions," pp. 527-562. An interesting slde-IIght to Channing's work on the Winsor set appears in the Draper-W1sconsin H1storlcal Soclety Correspondence at the State Historical Soclety of W1sconsin, Madison. Channing requested some aid of the wel1-known archivist Lyman C. Draper with some minor research problems, and apparently recelved it--in part. [Xerox coples of two letters from Channing to Draper, dated January 4, 1886, and January 17, 1887, are in the possession of 
once noted, the Winsor set was a "failure except as a mass of mater1al." 29

Channing contributed the entry on "The American Colonies" to the American Supplement of the ninth edition of the Encycloped1a Britannica in 1889. It was simply a brief description of colonial government based on the royal-proprietarycharter breakdown, and of colonial life using Virginia and Massachusetts as case studies. 30

Finally, of Channing's 'miscellaneous publications before 1905, mention should be made of the series of documents published under the editorship of Channing and Hart beginning in 1892. The purpose of the project was well stated by a reviewer for the Magazine of American History. The leaflets, he wrote, were "designed to promote the scientific method of studying history from its documents, and furnish in convenlent form coples of original documents that have become famous in our colonial and constitutional h1story."31 The general

the author.] According to Larry Gara, "Iyman Copeland Draper," in Cilfford L. Lord, ed., Keepers of the Past (Chapel H111: University of North Caroilna Press, 1965), p. 49, Draper, becoming with old age "more crotchety in his habits and more possessive about his collection," and having "little understanding of the newer academic historlans who increasingly turned to him for assistance," turned down some of Channing's requests.

29,W1Ilam A. Dunning, "A Generation of American H1storlography," in the Annual Report of the Amenican H1storical Association for the Year 1917 (Washington, D. C.: Government Printing office, 1920), p. 353 .

30 Edward Channing, "The American Colonies," American Suppiement to Encyclopedia Britannica, ninth edition, II, pp. 305-306.

31 Magazine of American History, XXVIII (November, 1892), pp. 399-400. 
title for the serles was American History Leaflets: Colonial and Constitutional. A total of thirty-s1x of them was pubIished, the last in 1913. Brlef editorlal comments introduced each document, followed by blbllographical references, then the document 1tself. Some of those included were the Constitution, the Ostend Manifesto, the Stamp Act, L1ncoln's Inaugural address, and the like. 32 This pioneering effort in making significant historical documents readily avallable to students was another projegt to which Channing could well be proud that his name was attached.

After 1905, the date of publication for the first volume of the Great Work, the amount of Channing's extraneous publ1cations decreased, and when he did produce something, it was usualiy directly related to his History. For example, he read three papers before the Massachusetts Historical Soclety, in 1910, 1911, and 1913, on "The American Board of Commissioners of the Customs," "Commerce During the Revolutionary Epoch," and "Washington and Parties, 1789-1797."33 These obv1ously grew out of Channing's research on volumes III and IV, as the

32 Edward Channing and Albert Businnell Hart, eds., Amerlcan H1story Leaflets: Colonial and Const1tutional (New York: A. Lowe1l and Company succeeded by Parker $P_{0}$. SImmons, 1892-1913). For a complete list of the learlets in the series, see George W. Robinson, Blbl lography of Edward Channing (Cambridge: Harvard University Press, 1932), pp. 8-11.

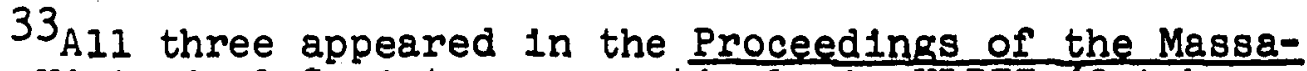
chusetts H1storical. Soclety, respectively in XIIII (October, 1909-June, 1910), pp. 477-490; XLIV (October, 1910-June, 1911), pp. 364-377; and XIVII (october, 1913-June, ig14), pp. 35-44. 
articles on "W11l1am Penn," "Colonel Thomas Dongan, Governor of New York," and "Kentucky Resolutions of 1798," which appeared in various places, grew out of the portion of his History Channing was working on at the time. 34

Channing did have one other writing project going in his very last years. This was his autoblography which he intended to call "The Recollections of a H1therto Truthful Man." His earliest mention of 1 t was in a letter to Brett in October, 1925. He referred to it then as simply his "memolrs." He sald it would "have to do mainly with the revolution in Harvard which has taken place in the course of my connection with 1t." He also noted that the project "appeals to Miss Moore because, as she says, we can l1e as much as we please in

\section{These articles appeared respectively in the Annual} Report of the American Historical Association for the Year 1906 (Washington, D. C.: Qovernment Printing office, 1908), I, pp. 191-197; Proceedings of the American Antlquarian Soclety, XVIII (October, 1907), pp. 336-345; and Amer1can H1storlcal Review, XX (January, 1915), pp. 333-336. One Channing article in the Proceedings of the Massachusetts H1stor1cal Society, XLVII (October, 1913-June, 1914), pp. 348355, grew out of a personal, more than a research, interest. It was a "Memoir of Thomas Wentworth Higginson."

Channing did no book reviews after 1905, and very few ever. It is easy to see why he wished to avold them if he felt obligated to be as thorough as he was in the one he did of J.A. Doyle's two-volume The English in Amer1ca: The Pur1tan Colonies for the English Historical Rev1ew, II (July, 1887), pp. 587-593--note the length! Channing gave a tribute to Doyle before the Massachusetts Historlcal Soclety also (Proceedings, I (1907-1908), pp. 196-198), mention of wh1ch leads to a category of listing in the Robinson B1bliography of Edward Channing which lengthen it considerably, but are not in most cases very important. These are the "remarks" by Channing on various subjects at the meetings of the Massachusetts Historical Society. 
that vol.,--which, of course, you understand we do as seldom as possible in the 'H1story." The work he actually did on it came in a few months in 1929-1930, and by then he had named 1t. "I am spending my lelsure moments in writing 'The Recollections of a Hitherto Truthful Man," he wrote. He seems to have enjoyed the work he did on 1 t 1mmensely. This is ev1dent from the pages of the document 1tself, but he also sa1d so in his correspondence. He told Brett in June; 1930, that he was soon going to Cotult to "have another whack" at the "Recollections," "the flrst pages of wh1ch I even now, when weary read with a chuckle."35 Unfortunately, Mrs. Channing did not enjoy them. "Madam does not l1ke them so we w11l abandon them for a time at any rate," he wrote to Miss Moore in July, 36 He never returned to the project, so, interesting though it is, it does not cover his Great Work and the major portion of his teaching career.

In conclusion, Edward Channing was a productive historian both quantitatively and qualitatively; after 1905 the quantity decreased but the quality increased. Of Channing's miscellaneous works, the outstanding ones were the quide, The Jeffersonian System, Town and County Government, and the American H1story Leaflets.

${ }^{35}$ Channing to Brett, October 20, 1925, August 17, 1929, and June 25, 1930, Macmilian Collection.

${ }^{36}$ Channing to Moore, "Prob. July 17, 1930," Channing Correspondence in Houghton Library. The tentative date was added to the letter by someone other than Channing. 
PART IV

\section{AN EVALUATION}

I think $C$ [hanning] and his work are underrated these days, and I hope your study w11l help to restore him to us.--Letter to the author from Crane Brinton, July 3, 1967. 
EDWARD CHANNING, HISTORIAN

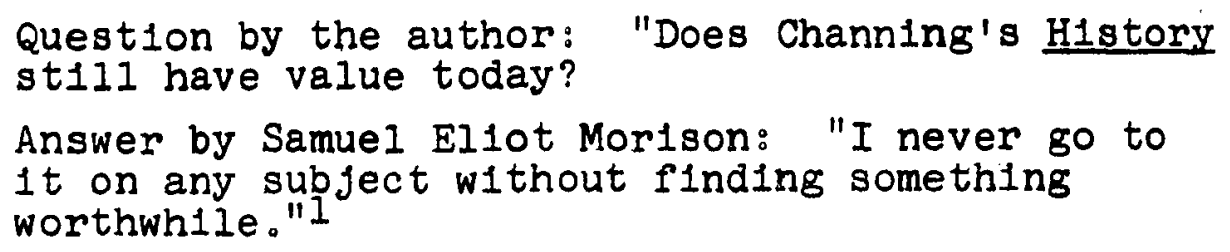

Several brief attempts have been made to evaluate Edward Channing as a historian. The most recent one was in 1963 by Glenn Weaver in Soclal Studies. Rather poorly written, it included no footnotes, and made several factual errors. Still, it included some ldeas of value. For one thing, Weaver discussed Channing in relation to several "schools" of historlography。 Though he admitted that Channing "was critical of all schools whether of history, philosophy, or literature," Weaver Insisted that Channing had "toyed" with Herbert Adams' "Teutonic Germ School" through h1s Town and County covernment, then rejected it in his remarks before the Massachusetts Historlcal Soclety. Weaver noted also Channing's rejection of the "Turner School," but contended that, even though Channing "would probably have been the first to deny 1t, certain passages [in his work] strongly suggest economic determinism." One of the main bases for this contention was Channing's comment that commerclalism was at the heart of the struggle

\footnotetext{
IInterview with Samuel El1ot Morison, June 9, 1967, Cambridge, Massachusetts.
} 


\section{7}

between England and America. Finally, Weaver thought "Channing would have been less unhappy about his inclusion, along w1th Osgood, Beer, and Andrews, as a member of the IImperial1st1c School." Though Weaver exaggerated to prove his point when he wrote that "Channing's pro-English bias is everywhere evident," his basic contention was correct. ${ }^{2}$ with Channing's Insistence in the preface to his Great Work that he "considdered the colonies as parts of the English emplre, as having sprung from that political fabric, and as having simply pursued a course of institutional evolution unlike" that of England, the Imperlalist1c, or, more commonly, Imperial School is certainly where Channing must be placed among colonial historians. 3

Weaver is not the only one who has had trouble placing Edward Channing in some neat historlographical category. Such a perceptive viewer of the course of American historical

2Glenn Weaver, "Edward Channing: A L1terary B10graphy," Soc1al Studies, LIV (March, 1963), pp.85-88.

3 Edward Channing, A History of the United States. Volume I: The Planting of a Nation in the New World, 10001600 (New York: The Macmilian Company, 1905), p. v. Allan Nevins compared Channing's work quite unfavorabiy with another member of the Imperial School: "Channing's volumes on the colonial period contain no thesis worth mentioning, while those of George Louls Beer contain a sharp-cut, novel, and emphat1c thes1s. The result is that while nobody ever speaks of Channing's 1deas, Beer's 1deas have been a staple of discussion ever since they were propounded; while we try to remember Channing's facts, we distinctly remember Beer's views."--Allan Nevins; The Cateway to History, New revised edition (Garden City, New York: Anchor Books, 1962), p. 295 . 


\section{8}

writing as Michael Kraus made statements about Channing which on the surface seem contradictory. In a 1937 volume ent1tled A History of American History Kraus placed Channing in a chapter on "The Imperial School of Colonial History." In what is essentially a revision of this work, however, published in 1953, Channing is a part of "The National1st School。" Kraus seemed to complicate matters still more by saying that Channing was "one of the earliest and finest products of the 'scientific school' of historlography in America." Finally, Kraus refers vaguely in one place to "the school of Edward Channing," apparently meaning the problem-solving technique of historlcal research. 4 Actually, there is no contradiction here at all. On most aspects of colonial history, Channing aligned himself with the Imperial School; on the Civil War, he was one of the outstanding nationalists. And as for his scientific approach and problem-solving technique, they tie him to no particular school; 1ndeed, they help explain and just1fy Weaver's contention about Channing's aloofness from all schools as such.

Weaver also commented on Channing's sources and style. Though he thought the reader would "doubtless be amazed at the great body of historical 11 terature which must have passed through" Channing's hands, Weaver emphasized that Channing's use of unpubl1shed sources was very limited. Indeed, he

\footnotetext{
${ }^{4}$ Michael Kraus, A History of American History (New York: Farrar Rinehart, Incorporated, 1937); and M1chael Kraus, The Writing of American History (Norman: University of Oklahoma Press, 1953), pp.232, 328 .
} 
found the great number of monograph1c studies c1ted "the most striking thing" about Channing's sources. Finally, Weaver contended that Channing usually made too much of the few sources that he did find that had never been used simply because of the fact that he was the f1rst to use them. Weaver stated that "Even the most casual reader would notice Channing's numerous infelicities of style," then went on to list some of the criticlsms varlous reviewers had made. He concluded that the most that could be sald for Channing's writing was that "the meaning is always clear." Finally, Weaver sald of Channing's H1story that it marked "the transition from the older school of narrative writers to the newer 'scientific' school." 6

The next most recent attempt at an evaluation of Chan ning's historical work would have agreed with this and more。 Th1s was by. John A. DeNovo, and appeared in 1952 in the M1ss1ss1pp1 Valley H1storical Review. Considering the space

5Weaver, "Edward Channing," pp.92-94。 The comments of other evaluations w11l be noted, but brlef ones from two other sources seem in order here. A former student wrote thus of Channing's sources: "His footnotes and end-of-chapter notes bear testimony to the extent of h1s research and furnish indispensable leads to other writers...." (Letter to the author from Ricinard I. Morton, July 7, 1966.) Van Wyck Brooks, though he recognized that Channing's H1stomy "In scope and massiveness...covered 1 ts field better than any other," was highly critical of the literary style. "There were few sparks of the artist In Channing," wrote Brooks. "He scarcely wished to be thought a writer. That history was a form of literature seemed to $\mathrm{h} 1 \mathrm{~m}$ to mean that it could not be a form of science, and. h1s work, with all 1ts dignity, was bald and-humdrum....Channing wrote for his graduate students," concluded Brooks -Van Wyck Brooks, New Ensland: Indian Sumer, 1865-1915 [(Now Y75.

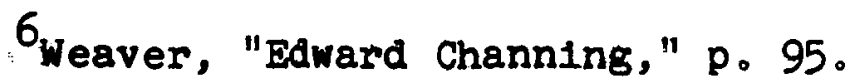


he had, DeNovo did an excellent job. Certainly he had his criticisms. Channing sometimes falled, he noted, in his attempt to evaluate individuals and movements in terms of their own times. DeNovo admitted that Channing's generalizations sometimes made the reader "raise his eye-brows." He took note of Channing's "never quite successful effort to solve the ever-present problem of organizing and weaving together his narrative." He also considered justiflable the criticlsms which had been made of Channing for his "undying New England point of view" and his over-emphasis on the political. Finally, DeNovo felt that"Channing's achlevement in historical method ranks high, while he falls down in the art of synthesis and 1nterpretation."17

The over-all tone of DeNovo's evaluation, however, was quite favorable. He considered Channing a master at the succinct evaluation of Individuals. He thought the amount and varlety of sources used for the Great Work "staggering," and contended that Channing was "a careful workman who seldom lost sight of the need for the rigorous application of h1storical method to his evidence." He pra1sed Channing's use of the "tools" of foreign languages, stat1st1cs, and geographical information. Finaliy, DeNovo wrote that even the "severest appraisers hestitate to challenge Channing's intellectual honesty or sincerity," that practically all reviewers "have

\footnotetext{
7John A. DeNovo, "Edward Chann1ng's 'Great Work' Twenty Years After," M1ss1ss1pp1 Valley Historical Rev1ew, XXXIX (September, 1952), pp。262-272。
} 
found more to praise in Channing than to criticlze, "and that "The agreement is almost complete that his was a unique accomplishment of high quality。" 8

The most critical evaluation of Channing was by Ralph Ray Fahrney. It was published as a chapter in the Marcus $W_{0}$ Jernegan Essays in American H1storlography in 1937. There are, of course, many valid criticisms which can be made of Channing's historical work, and Fahrney pointed out most of them, plus some others. He weakened his case, however, by exaggerating and by such tricks as quoting only the most critical portions of basically favorable book reviews. Certalniy it was an exaggeration to say that Channing's "entire life, except for brief trips, was spent in the New England environment, from which he seldom strayed," and that his interpretations therefore Indicaicd "viewpoints and prejudices traceable to the Atlantic coastline." So was it exaggerated, if not completely wrong, to write that "Channing was disposed at all times to underrate, or ent1rely disregard, sectlonalism as a force in American history." 9

Fahrney wrote that "Perhaps the greatest weakness of Channing is his faulty organization of material and technique

${ }^{8}$ Ib1d., pp. 261, 268, 271-273. DeNovo gave examples of footnotes in the History in Spanish, French, derman, Italian, Norweglan, and Latin. By statistics he meant primarliy Channing's utilization of census figures. The maps he considered the major benefit of Channing's geographical information.

9Ralph Ray Fahrney, "Edward Channing," in W1lliam T。 Hutchinson, ed., The Marcus $w_{\text {. Jernegan Essays in American }}$ H1storlography (Chicago: University of Chicago Press, 1937), pp. 296, 299-309. 


\section{2}

of presentation." He suggested a possibility ignored by aII other Channing critics, but one which seems quite logical, when he attributed this problem of Channing's to the same type practice in teaching, $1_{e} e_{e}$, lecturing without notes because of his contempt for the "finished lecturer" and the "spoonfeeding" of students. Fahrrey was willing to concede that Channing's style "merits nelther high pra1se nor sharp crit1c1sm," and that his sources were "adequate, both in number and varlety."10 He concluded:

After the most critically minded have had their innings dissecting and analysing the Channing history w1th the avowed purpose of unvelling all of 1 ts deficlencles, there still remains a bountiful measure of praise to be awarded to the one American historian of the twentleth century who had the courage to attempt a task so colossal. If other historians managed to escape some of the snares into which Channing stumbled, it was in large part because they 11 Iimited their endeavors and trod upon safer ground. ${ }^{11}$

Carl Russell FIsh made one of the earliest attempts at assessment of Channing the h1storian. H1s brief effort was published in Current H1story in March, 1931, only two months after Channing's death. Considering the date, and the fact that Fish was something of a friend of Channing anyway, the evaluation was a remarkably good one. Flsh did not have unqualified praise for Channing's work, for he recognized that there were valid criticisms, but the overall tone of

$$
\begin{aligned}
& 10_{\text {Ib1d., }} p p_{0} 307-309 . \\
& 11 \text { Ib1d., p. } 311 .
\end{aligned}
$$


his comments was, of course, fayurable. He considered Channing "one of the first of our scientific historians."12

Another evaluation of Channing written soon after his death and by a person who knew him well was "Edward Channing: A Memo1r." By Samuel Eliot Morison, it appeared in the Proceedings of the Massachusetts H1storical Society. Morison's remarks before that soclety, of which Channing had also been a member, still constitute one of the most useful evaluations of Edward Channing avallable in print. To Morison the "wholeness of view" evidenced in the preface to the Great Work was one of Channing's distinguishing characteristics as a historian. Channing, thought Morison, "leaned over backwards to give other points of view than the orthodox New England ones, their proper place; and he succeeded notably." Morison considered Channing's "most striking characteristic as an historian," how ever, to be "his ablilty to wipe his mind clear of preconcelved interpretations and theories, even if he had been teaching them all his life; to study every question and perlod anew, from the sources, and to reach fresh conclusions." There was, concluded Morlson, "hardly an important question, from Jamestown to Appomattox, on which his views were orthodox."13

12 Carl Russell Fish, "Edward Channing: Amerlca's" Historian, "Current History, XXXIII (March, 1931), p. 864.

13 Samuel Eliot Morison, "Edward Channing: A Memolr," Proceedings of the Massachusetts H1storical Soclety, IXIV (october, 1930-June, 1932), pp.278-279。 In an Interview, Morison stated the same thing more succinctly; Channing's great quality as a historian, he sald, was "his ability to 
Morison was willing to agree with those who criticized Channing's style. He once proclalmed as a general principle that "Dictation is usually fatal to good historical writing."14 In Channing's case, he thought it "resulted in a rather formless, and occasionally slipshod style."15 Though Channing was Incapable of It himself, he did appreciate good historical prose, and, as Morison proudly recalled, used to read brief passages from Morison's own Mar1t1me History of Massachusetts to students as an example of how to write history. 16 According to Morlson, Channing was aware of his styl1st1c deficlency; yet to others, he seemed actualiy proud of his style. Richard I. Morton recalled that "Channing once remarked that the h1storlan should be able to write at odd moments-mto turn his work on and off like a spiggot." Frederick Merk salu that Channing took great pride in his mode of composition, and was known to compare his books to a string of pearls, with as 11ttle connective tissue between the parts as possible. 17

change an opinion upon learning new facts." (June 9, 1967, Cambridge, Massachusetts。)

${ }^{14}$ Samuel El1ot Morison, By Land and By Sea: Essays and Addresses (New York: Alfred A。Knopf, 1953), p. 293. 15 Mor1son, "Edward Channing," p. 280. 16 Interview with Samuel Ellot Morison, June 9, 1967, Cambridge, Massachusetts.

17 Letter to the author from Richard L. Morton, July 7 , 1966; Interv1ew w1th Freder1ck Merk, August 22, 1966, Cambridge, Massachusetts. Both these Individuals agreed with Mor1son rather than Channing as to the results of Channing's method, Merk stating that it was all right for readers who were thoroughly familiar with American history but difficult for 


\section{5}

Morison certainly was not willing to agree with those who contended that Channing's volumes were composed by simply stringing together the works of others. "Channing carried out his promise to write the History from the original sources," he wrote. Morison did acknowledge that Channing made little use of newspapers as a source, and that this was a distinct loss, especlally for volumes IV and $V_{0}{ }^{18}$

A. Lawrence Lowell's published evaluation of Channing also appeared soon after Channing's death. It was not as objective or as serious as Morison's, and thus had less value. Lowell found no fault in Channing's History, and concluded that it was "an achievement that in 1ts scope and detalled study of the sources will never be repeated."19

Channing's grandson, John Channing Fuller, when a senior at W1111ams College in 1943, wrote a thesis on Channing in order to recelve a degree with honors in history. Though both the undergraduate nature of the work and the familial relationsh1ps of author and subject are frequently obvious, some parts of the study are very useful. Best of all is a section in which Fuller discusses what he considers the "nine

those who were not, and Morton writing that the system perhaps accounted for Channing's writings not possessing "the easy flow of those of such historlans as $S$. E. Morison or of Louls B. Wright。"

18 Morison, "Edward Channing," p. 280 .

${ }^{19}$ A. Lawrence Lowell, "Edward Channing," American Academy of Arts and Letters Publication No.77, 1932, p.83. 


\section{$3+15$}

ma1n highlights" of Channing's H1story. The first of these distinguishing characteristics was the success which Channing achieved in 1llustrating his "victory of the forces of union over those of particularism" theme stated in the preface. The second was Channing's attention to, and ab1l1ty to character1ze, important individuals. Channing's "inclination to upset historical traditions" was considered a third outstanding tra1t, and 1ndeed "one of the greatest highlights" of the entire set. Channing's "definite emphasis on and interest in commerclal and maritime history" and his "recognition of the connection of the American colonies with England and his realization that America has always been in the world" were considered the fourth and fifth distinguishing points of the History. Sixth on the 11st was the cartography. The seventh 1tem, this one In "the realm of technical procedure," was "the prolific use of footnotes and notes at the end of each chapter." Though it was not considered "one of the main outstanding elements," Channing's style was Iisted by Fuller as the elghth highlight of the Great Work. The final distingulshing characteristic was Channing's broad-mindedness. 20

W1thin these nine "highlights," most of the distingulshing characteristics of Channing's Great Work are Included. Two of the nine, however, probably do not deserve to be 11 sted

20 John Channing Fuller, "Edward Channing: Essays on The Man, The Teacher, and The Writer," (Unpubl1shed senior honors thes1s, W1111ams College, 1943), pp.88-107. 
along with the others. The cartography was simply not a major aspect or an Integral part of the H1story, and most of 1 t was not, of course, the work of Channing anyway. Likew1se, it is difficult to Justify considering Channing's style a "highlight" of h1s historlcal work. If one agrees that Channing's style "deserves l1ttle comment, other than that 1t was sufficlent for h1s purpose,"2l as Fuller himself stated, then why list it as one of the H1story's outstanding points?

None of these brief evaluations of Channing did much in the way of comparing him with other historians who produced mult-volume historles of the United States. Only a small group d1d so, the most 1mportant of whom were George Bancroft, Richard Hildreth, Hermann von Holst, James Schouler, John Bach McMaster, James Ford Rhodes, and Woodrow W1Ison. Four of these were already through the1r "great works" before Channing began h1s.

Bancroft (1800-1891) began his vast treatment of the American past in 1834 and finished 1t, in twelve volumes, in 1882, the year before Channing began his Harvard teaching career. In those twelve volumes, Bancroft never moved beyond the year 1789. And, though h1s work was a supreme accomplishment for his time, with its uncritical treatment of everything American the works of Channing and other more scientiflc historlans soon relegated it to the shelves to be covered with $\because$ dust.

$$
21_{\text {Ibid. . p. } 107 .}
$$


Richard Hildreth's (1807-1865) six-volume history, pub11 shed between 1849 and 1851, enjoyed great vogue in the colleges in the later decades of the nineteenth century, but soon followed Bancroft to the unused book shelf. It was obvlously blased toward the Federalist-Wh1g-Republican Interpretation of American history throughout, and 1t never went beyond 1821. H1ldreth may have Influenced Edward Channing negatively, but he seems to have had a positive Influence on Hermann von Holst (1841-1904). Th1s author produced, in the years 1876 to 1892 , seven volumes which were much admired in his day. In real1ty, however, h1s work was only a very blased Northern politicalconstitutional history of events centering around the slavery controversy from 1781 to 1860 , and 1 ts popularity was shortlived.

Woodrow W1lson's (1856-1924) flve-volume History of the American People, published in 1902, really does not deserve to be ranked with these other works, prejudiced though they were. It was a popular work which could have been printed in only two volumes easily by eliminating the hundreds of 11lustrations.

John Bach McMaster (1852-1932) published the elghth and final volume of his pioneering social history of the Amer1can people in 1912, bringing h1s narrative through the C1v1l War. Channing that year published the third volume of the Great Work, dealing with the Revolutionary era, which, inc1dentally, had been McMaster's starting point back in 1883. 
These two apparently never regarded each other's work very highly, but this may have been partially a result of the fact that they also competed in the textbook fleld.

The nationalist historlan James Schouler (1839-1920) completed h1s seven-volume work, begun in 1880, in 1913, and became the first to cover the entire $1789-1877$ period by a cont1nuous narrative. James Ford Rhodes (1848-1927) completed h1s famous nine-volume work on the 1850-1909 period in 1922. After that, Channing was the only major American historian st1ll working on a mult1-volume general history of the United States. What was to be h1s last volume appeared in 1925. Edward Channing, then, came nearer to covering the ent1re span of American history from beginnings to his own t1me than any of these other historians. And he did so in a fashion which bears the scrutiny of modern historical scholarship at least as well as any of them. As Morison.sa1d, "Channing accomplished what no man had done before, and what is not likely to be done again... With his own hand, and from his own research, he wrote a great history of the Un1ted States from the beginning of colonization to the close of the C1vil War." 22

One thing of use in an over-all estimate of Channing and the historian is his own philosophy of history. Samuel Ellot Morison stated that Channing "had no 'ph1losophy' of

$$
22 \text { Morison, "Edward Channing," p. } 284 .
$$


history, to my knowledge, other than Ranke's wie es gewesen which I think I heard him quote." 23 This by no means gives a complete picture. True, Channing felt no compulsion to distort the facts of American history to make them fit some particular thread of interpretation, economic or otherwise. And, except for an apparent underlying belief in evolution and progress which he held in common w1th most of his generation, he embraced no sweeping theory of history l1ke Henry Adams or Arnold Toynbee. H1s goal was plain, yet very difficult of attainment: the writing of an extensive objective narrative history of the United states from the beginning of colonization to his own time based on the sources. Closely related to this ambition was Channing's desire to teach objectively and to write an unblased text. Except for the fact that he did not quite make 1 t to his own time, Channing fulfilled his objectives to a remarkable extent. What motivated him to do all this? Many factors played a part: determination to accomplish something because he felt his father had not; inspiration from the works of such historians as Francis Parkman and Henry Adams; reaction against the dogmat1sm of Henry Cabot Lodge's teaching and the bias of Richard Hildreth's writing; and, finally, that Indefinable quality that some men have which drives them persistently_on_toward some great goal.

23 Letter to the author from Samuel El1ot Morison, September, 13, 1967. 
In addition to all this, Channing did come much nearer to stating a ph1losophy of history than Morison's statement would suggest. He wrote an art1cle in 1910 for the Proceed1ngs of the American Antiquarian Soclety. H1story, he sald there, "Is a mode of thought and expression. Historical writIng is the application of the historical method to expression with pen and Ink." Historical labor, Channing continued, could be divided 1nto three types: "(1) the collecting and printing of orlginal sources; (2) the reporting on masses of materlal or on spec1fic top1cs; (3) historlcal writing." The first two types he considered craftsmansh1p, the third art. Channing recognized that the craftsmanship was a necessary prelude to the art, but he could not avold showing a little contempt for the producer of the second class of historical labor, which Included predominantly reports, theses, and dissertations. "Q1ven an adequate amount of material and a sufficlency of time, he must be a mediocre man, indeed, or one whose brain has become indurated, who cannot produce a monograph or volume, or even a series of volumes of this type," thought Channing. 24 In another place he expressed strong disapproval of "the $\mathrm{Ph}, \mathrm{D}$. thesis maker thinking that he is an historlan--somethlng like the complier of a lot of statistics about the infury of one's organs by tobacco thinking that he is a scientific man."25

\section{Edward Channing, "The Present State of H1storical} Writing in America," Proceedings of the American Antiquarian Soclety, XX (October, 1910), pp。 427-428.

25Edward Channing to "Mr. Johnson," March 5, 1912, Century Collection, Manuscript Division, New York Public Library. 
"The qualifications of the h1storian are multitudinous," proclaimed Channing. He then proceeded to 11 st and discuss them, giving particular attention to "1magination," "broad sympathies," an understanding of the fundamentals of both law and science, and "perspective。" The historian, sald Channing,

must have training in research, must be able to handle material in manuscript and in printed form, and to sift the truth from the falsehood. He must have the faculty of using the work of others, of recognizing first-class monographs at a glance, almost. The materials of American history are so vast that the historian, even of a falriy limited perlod, can hardly hope himself to read all the original sources. He must use the work of others; but he himself must also constantly be using origInal materials; otherwise he will lose the faculty of recognition; and he w111 miss that local color and flavor which make historical writing tolerable。26

Channing met h1s own requirements here remarkably well for the author of a mult1-volume history. He was also the master of another technlque he recommended. The historian, he wrote, should seek "to tell the story in such a way that his readers $w 111$ become convinced w1thout being aware that they are being argued with." But his requirements concerning the historlan being "a master of perspective," Channing did not meet so well, even though he showed that he was aware of the pltfall:

Th1s is one of the most difflcult of all achlevements for the historian, because in his researches, he 1s likely to come upon new materlal relating to some one part of his studies that no one else has ever seen, or rather that no one else has ever understood. The temptation is great to apportion

\footnotetext{
${ }^{26}$ Channing, "The Present State of Historical Writing," p. 429.
} 
h1s space according to the 1mportance of the events
or the men.27 Channing made it clear in his discussion of 1magination as a qualification for the historian that he considered the conveying of a truthful impression to the reader the essential thing.

oftentimes, to do this he [the historian] must sacrifice absolute accuracy in detall and in perspective. If the impression produced upon his reader is truthful, it matters little whether all his dates are correct, all his names are properly spelled, or if all h1s facts are accurate. Indeed, h1s dates may every one of them be correct, his names may all be properly spelled, his facts may be absolutely accurate, and the Impression left upon his reader be entirely false.28

Channing toyed with economic determinism more in this article than anywhere in the H1story. Emphasizing the necess1ty for the historian having broad sympathies-an "He must have some sympathy w1th the ways of the economist and must regard the march of fact in the light of the laws of human development"--Channing went on to say that there was "no such thing as economic history; all history is economic. All historical development is founded upon Industry, upon the necessity of supporting iffe, and the way in which it is done. It is 1mpossible to separate economic history from political history."29

27 Ib1d., p. 431 .

28 IDe19., R. 430 . 22 I01d., pp. 430-431. 


\section{4}

Franc1s Parkman was used as an example of a great historlan by Channing in his concluding remarks. Channing lamented the state of scholarship in America as of 1910, especlally historlcal scholarship: "In looking about for writers of history in this country at the present moment, the seeker is met with greater discouragement than would befall him in almost any other path of original research... There has not been a time for many years... when scholarship has been so lightly valued in the United States as it is at the present moment."30 The conclusion, however, was optimist1c:

Some day the wheel w1ll turn around; scholarship will again be valued as a national asset; and a new Parkman w1ll arise! Possibly, he may produce only one volume, but if that volume shall be of the qual1ty of the "Ploneers of France," 1t w111 do more for the cause of educating the plain people and the bullding up of his own reputation than the printing of documents by the ton or the publication of monographs by the dozen. 31

One of Channing's former students has sald that his "emphasis was upon people and how they acted and how they felt, particularly in moments of personal crisis or during the rites of passage affecting all of humanity." Channing, this person continues, "Insisted upon the necessity of students' 1dent1fylng with historical situations and personages. I presume this was all he thought about historlography."32 It is

\section{${ }^{30}$ Io1d., p. 434 .}

\section{Ib1d.} 18, 1966.

${ }^{32}$ Letter to the author from Edward C. K1rkland, July 
certainly true that one of the "highlights" of Channing's historical work was his own 1dentification with and ability to portray historical situations and Individuals; Carl Russell F1sh sald Channing had "reactions as personal to the Boston of 1630 and the Philadelphia of 1776 as to the men and things of h1s own days."33 But that this was not "all he thought about h1storlography" should already be evident. He gave appropriate attention to economic factols; he also emphasized the need for the historian having an understanding of geography. "History is the record of man's experience on this earth," Channing once wrote; "geography is the description of the forces of nature which have affected man's dest1ny. W1thout a knowledge of the latter it is 1mpossible to understand the former."134 F1nally, he saw the need for an integrative approach to the study of history in this simple, but meaningful, passage from h1s last volume:

A quarter of a century ago [written in 1925] or a third of a century ago, it was customary to lay great stress on the inf iuence of economic factors; now 1t is more often the case to emphasize the soclological or psychlcal change that 1s wrought by changed modes of living and by the general operation of economic factors. Possibly the best way to analyze problems of progress or of change in human. outlook would be to combine all these various

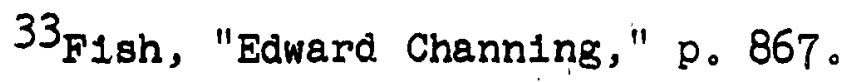

34 Edward Channing, "The Relation of Geography to H1story," Journal of Proceedings and Addresses (St. Paul, Minnesota: National Education Association, 1895), p. 193. 
factors into one, for surely one!'s mode of living exercises a very important influence on one's mode of thinking. 35

Channing's "past-mindedness" was noted in connection with his presidential address before the American Historical Association in 1920. Frederick Jackson Turner had written in 1917 that Channing was "settled in his conviction that it is futile and superficial to try to apply past precedents to present predicaments."36 Channing was even more strongly opposed to looking into the future as an activity for the historian. He made the point in a humorous fashion in a letter to President Brett of the Macmilian Company at one time. "My boys are constantly asking me to prophecy," he wrote, referring of course to his students. "I answer that the business of the historian and the prophet are distinctiy different; that if I could prophecy, I should be a triple b1111onaire and not a prophesseor (this started to be a pun, but it doesn't look well)."37 He sald the same thing more seriously in the sixth volume of the History, where he wrote that "one of the first things that the historical student learns to

\section{Edward Channing, A History of the United States.} Volume VI: The War for Southern Independence Tew York: The Macmilian Company, 1925), p. 383.

\section{Frederick Jackson Turner to J.Franklin Jameson,} Maỳ 20, i917, John Franklin Jameson Collection, Manuscript Division, Library of Congress, Washington, D. C.

37 Edward Channing to George P.Brett, [President, Macmilian Company], July 12, 1919, Edward Channing File, Macmilian Authors Collection, New York Publ1c I1brary。 
distrust is the vitality of the prophetic vision of himself or of anyone in ages past. Prophesying is the most dangerous of all historical pursults and also of political pursults。"38 Channing once became involved in something of a historical controversy, one result of which was a further elucidation of some of his 1deas about history. The scene took place before the Massachusetts Historical Soclety; the subject was the origin of New England towns; one of the other members had classed Channing as a leader in the somcalled "New H1storical School" along with Herbert Baxter Adams,'John Fiske, and others, because of his stand on that issue. "If the line which separates us from the '0ld Historical School' is the fact that we of the 'New' base our theorles on the records, whlle the older writers copled one from the other, I am well content to belong to the New School," he sa1d. Since the method used by these modern writers was the true historical method, Channing continued, they should actually be called the "True Historlcal School."39 He elaborated:

Tize true historlcal method consists in the examination of original records and other contemporaneous sources, and in generalizations based on such research. Where the generalizations are based on a sufficient number of records; the method $1 \mathrm{~s}$ the Tine vacnis best

best which has yet been devised. 40

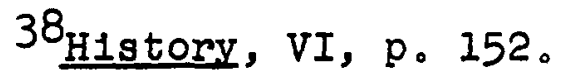

39 Edward Channing, "A Few Remarks on the Origlns of New England Towns," Proceedings of the Massachusetts H1storical Soclety, III (1891-1892), pp。242-244。

$40_{\text {Ib1d. }}, p .244$ 。 
A good point about the continuity of history was also made by Channing at this time:

Historical students are accustomed to divide history into periods, for convenience' sake. For example, we speak of Medleval History and of Modern History, as if they were things entirely apart. As a matter of fact, it is impossible to say when one begins and the other ends. In a similar way we speak of the Middle Ages, as to the beginning and end whereof few scholars are agreed. This theory of the continuity of history applies with especial force to the history of institutions, as institutions are of very slow growth and are rarely invented, but almost always evolved from something which went before. 41

Channing's mention of institutional history leads to a major point about him as a historian. Paul H. Buck considered Channing's "emancipation from the dominant school of institutional historians" to be most significant. Channing, he noted, began to turn away from the political to the social, 11terary, and the like, but he falled to make 1t an integral part of his story. 42 It $1 \mathrm{~s}$, of course, true that Channing began to devote space to the non-political, especially in his fifth volume. Sometimes the chapters on these subjects were quite weIl done and thoroughly interesting; but it is also true that this materlal usually seemed strangely unrelated to the centra. story. Perhaps Harvey Wish stated it best when he wrote that Channing "rounded out institutional history with soclal developments."43

\footnotetext{
$4 I_{\text {IoId. }}, p .245$.

42 Interview with Paul H. Buck, June 9, 1967, Cambridge, Massachusetts。

43 Harvey Wish, The American Historian: A Sóc1al-
} 


\section{9}

Edward Channing, then, did have a working philosophy of history, certainly much more of a philosophy than has gener ally been credited to him. How he applied this to United States history specifically is best seen in the preface to his Great Work. He intended to treat the growth of the nation as one continuous development, he announced, "from the pol1t1cal, m1l1tary, 1nstitutional, industrial, and social points of view." Channing showed his alignment with the Imperial School of colonial historlans when he proclaimed that he "considered the colonies as parts of the English emplre, as having sprung from that political fabric, and as having simply pursued a course of Institutional evolution unlike that of the branch of the English race whlch remalned behind in the old homeland across the Atlant1c." It was here in the preface that Channing stated that he considered the v1ctory of the forces of union over those of particular1sm "the most 1mportant single fact in our development." Channing was doubtless Influenced by the evolutionary climate of opinion of his day in selecting what he called the "guiding 1dea" of his H1story: "to v1ew the subject as the record of an evolution, and to trace the growth of the nation from the standpoint of that which preceded rather than from that which followed." 44 He elaborated:

In other words, I have tried to see in the annals of the past the story of living forces, always struggling

Intellectual History of the Writing of the American Past (New York: Oxford UnIversity Press, 1960), p. 128.

44 History, I, pp. v-vi. 


\section{0}

onward and upward toward that which is better and higher in human conception. It is only in this way that justice can be done to the memorles of those who have gone before and have left for us a splendid heritage. They treated the problems which arose in their time by the light of the age in which they 11ved. To estimate them by the conditions and 1deas of the present day is to give a false picture to the reader and the student. 45

In attempting an over-all assessment of Channing, it is periaps not inappropriate to compare him with Albert Bushnell Hart, for their careers paralleled each other in so many ways. Two brief evaluations of Hart have appeared in print recently, one by Carol F. Balrd and the other by Samuel Ellot Morison. Morison's article included little of value on Channing, except that in h1s opinion, "Channing was the better scholar of the two, but Hart the better al1-around man, and at least Channing's equal as a teacher." 46

The Ba1rd appra1sal of Hart, however, can be qu1te useful in understanding Channing. On at least one point, Channing and Hart differed slgniflcantly, for Hart's "conception of history was dominated by the 1dea that an understanding of the past would enlighten the present." According to this author, one of the factors contributing to the "Increased selfconsclousness of historians as a professional group" in the late nineteenth and early twentleth centuries was their belief

45 Ib1d., p. v1.

${ }^{46}$ Samuel El1ot Morison, "A Memo1r and Estimate of Albert Bushnel1 Hart," Proceedings of the Massachusetts H1storical Soc1ety, LXXVII (January-December, 1965), p. 33. 
that h1story could be a sclence. There were two variants of this bellef, however, one that history could yleld laws and generalizations like the sciences, and the other that science In history was simply a method, a search for objective facts Impartially reported. 47 Channing would have agreed with only the second concept.

Many things sald here about Hart apply equally well to Channing. "Hart contributed no truly original 1deas to the study of history," wrote Balrd; "he made no brilliant and lasting synthes1s of the material at h1s command." Bas1cally, this is true of Channing as well. This author credited Hart w1th revitalizing the teaching of American history through replacing "learning by rote" w1th the problem approach, outside reading, student reports, and the like. Hart himself was more realistic in being willing to share the credit for these innovations w1th Channing. "I hope 1t may be remembered for righteousness," he wrote to President A. Lawrence Lowell in 1922, "that next after Henry Adams and Henry Cabot Lodge, Channing and I have the honor of introducing on a considerable scale the study of special toplcs in American h1story." Finally, Hart and Channing apparently made similar efforts to break with the traditional conception of history as past pol1t1cs. "Although Hart devoted much of h1s time to political

\footnotetext{
47 Paul Buck, ed., Soclal Sclences at Harvard, 18601920: From Inculcation to the Open Mind (Cambridge: Harvard Univers1ty Press, 1965), pp. 133-139. The chapter on h1story centered on Hart, and was written by Carol $\mathrm{F}$. Baird.
} 
material, he attempted to introduce elements of economic and social h1story, as he understood them....H1s attempts...were primarily descriptive; he did not have a sense, as one does today, of the ways in which political and economic and soclal phenomena may be causally interrelated." 48

Edward Channing once asked: "And how can any master of history use the gifts with which he has been endowed better than by stimulating others to work as he himself has worked?" 49 It is interesting to speculate as to how successful Channing himself was according to that criterion. He once wrote this of his Great Work:

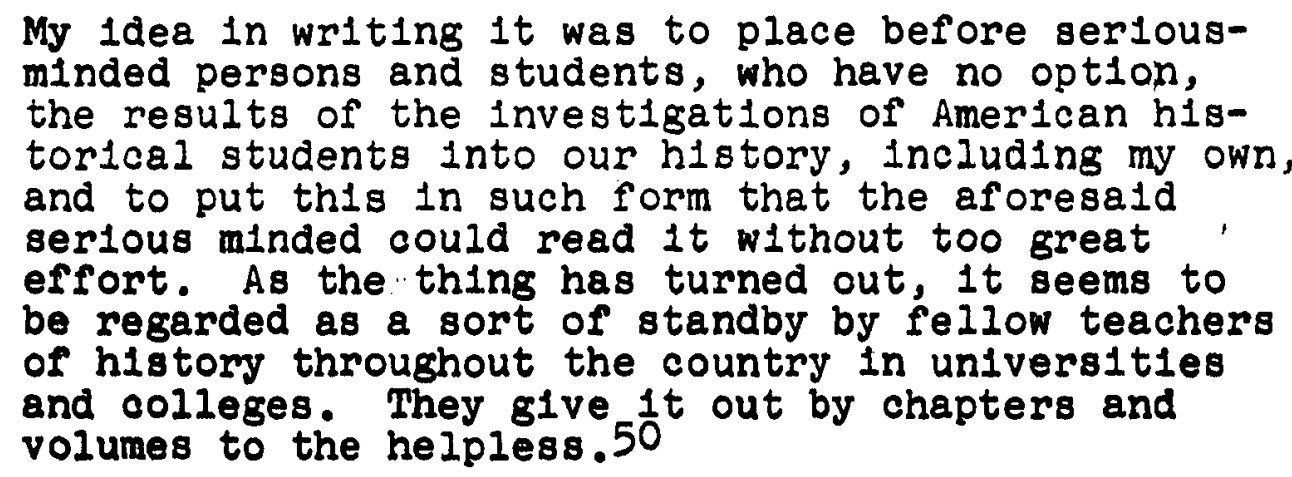

Channing's Great Work did Indeed become something of a "standby" for history teachers, and remalned such for a long t1me. The Macmilian Company was st1ll printing it as late as 1958. The most recent figures ava1lable as to number of coples

48 Ib1d., pp. 147-161.

49 Edward Channing, "Remarks on Charles Deane," Proceedings of the Massachusetts H1storical Soclety, $V$ (18.90): p. 136 .

${ }^{50}$ Harvard Coliege Class of 1878: Secretary's Report, Ne. VII, 1917, p. 13 . 
printed by the company indicate that sales were quite good for a work used largely for reference purposes and by graduate students. These flgures, dated 1946, are: Volume I, 14,400; II, 12,500; III, 13,200; IV, 10,950; V, 9,450; and VI, 8,600.51 The obvious 1mbalance is probably accounted for by the simple fact that the later volumes had not been out as Iong as the earlier ones; sales probably evened up as time went on.

Channing's comments on the subject in his correspondence with Brett show that he was basically pleased with sales, and that he put the money to good use. Brett himself always felt that sales would greatly increase when the set was completed, and frequently used this to push Channing along. Typlcal was this comment in a letter of 1917:

Increasingly your book takes up the most important position in current historical literature and the sales, while not large, are satisfactory, and w111, I think, Increase as time goes on, and when the happy day comes that the work is completed, I belleve a very large sale of the set can be accomplished.52

The set was never really "completed," of course, but sales apparently did plck up after the publication of the s1xth volume. Brett 1nformed Channing in November, 1926, that there was "an Increasing demand for the H1story this year," and that the sixth volume was running well ahead of all the others. 53

\section{I DeNovo, "Edward Channing's 'Great Work' Twenty Years} After," p. 274. The source of DeNovo's flgures was a letter to hIm from Harry B. McCurdy of the Macmilian Company dated Apr11 17, 1946.

52 Brett to Channing, July 26, 1917, Macmillan Collection. 53 Ib1d., November 19, 1926. 
During the year 1925, Channing commented twice to Brett on sales. In June he wrote:

I was looking over our letters of 1897 or 1898 in which we outlined the work and the contract. I certalnly never expected to write a book that would recelve the recognition by scholars that this book has recelved or bring in the amount of money that th1s book has brought in. If I remember rightly, you never expected to sell many coples until the set was completed, somewhere about our seventy-fifth year. I am glad that our anticipations failed of realization and that the book has brought in money every year to you and to me. Let us hope that it w111 keep right on dolng so. 54

In October he speculated about methods of completing the set, then concluded: "But we have sold quite a lot of coples and both of us have made money, so 'Why worry?'" There was also a postscript: "And we are going to make more money by 1 , too. 1155

As for the use to which Channing put the earnings from his books, not a great deal is known. He seems to have continued throughout his life the hablt he developed as a Harvard student of small-scale stock speculation, but mostly he placed his extra income in savings. Commenting on this to Brett in a 1927 letter, Channing sald, "I am writing this to let you see that I make a good use of the moneys which my books earn for me and do not spend them in stock gambling or in 1dle living." 56 His comment to Brett in 1923 that "when the book 1s completed

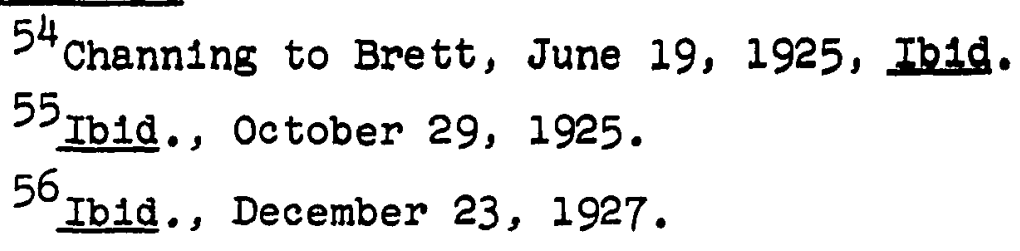




\section{5}

and sel1s by the hundred thousand coples, my he1rs will rejolce and my ashes w111 rise out of Cotult Harbor and raise a paean of joy," 57 was not all in jest. According to one of his grandsons, Channing was a "shrewd" financial person who left "a small fortune" when he died, and the family is st111[1966] get ting royalties from his books. 58

Such information as this, however, conveys only a small part of the influence of Edward Channing as a historian. There is no doubt of the influence of "thesis" historians such as Beard and Turner, at least in the stimulation of research. For a historlan such as Channing, noted primarily for a comprehensive general history, determination of such direct influence is much more difficult. St1li there is some evidence of 1 . At least five students of Channing who became prominent themselves pald tribute to him in one form or another. These were Samuel Ellot Morison, Evarts B. Greene, Carl Russell F1sh, Samuel Flagg Bemis, and James P. Baxter III.59 In addition to the History, with 1ts direct influence and stimulus to further research, surely it is safe to assume a great deal of Influence on the part of a person who taught for forty-seven years at one

\section{Ib1d. , October $8,1923$.}

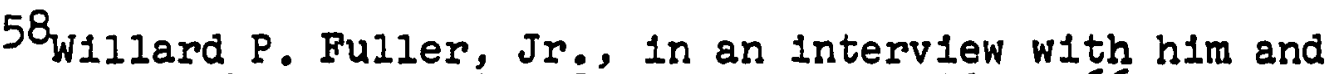
h1s mother, Elizabeth Channing Fuller, August 19, 1966, Chatham, Massachusetts.

59 DeNovo, "Edward Channing's 'Great Work' Twenty Years After," p. 273; and James Phinney Baxter III, The Introduct1on of the Ironciad Warship (Cambridge: Harvard University Press, 1933), p. v111. 
of the nation's great educational institutions, who co-authored one of the finest b1bliographical guides to American h1story ever produced, and who wrote one of the best and most widely used Unfted States h1story textbooks in the f1rst quarter of the present century。

Certainly Channing had a high reputation at the time of his death. Realizing the tendency to over-statement in ob1tuarles, st111 it surely is not devold of signiflcance that Channing's passing was lamented and h1s work praised by such diverse and 1mportant publications as Time, the Nation, 60 and the American H1storical Review. Sald the latter:
A falthrul and v1gorous teacher,... he trained a multitude of students in the appilcation to... history of his own high and exacting standards, and was their steady friend ever after... The merlts widely recognized in this monumental work [the H1story] $11 \mathrm{e}$ in the thoroughness of the author's researches, h1s constant use and recognition of special monographs preceding, the determined falrness w1th which he strove to emanclpate himself from Bostonian prepossessions, h1s sturdy independence, and, especlaily in the later volumes, a freshness of view which led him, disregarding traditional valuations, to place his emphasis on the things that seemed to him really significant.61

If the American H1storical Review was Inclined to exaggerate on the occasion of Channing's death, perhaps Hart would not have been quite so inclined to do so on the occasion of Channing's resignation. Here is what he wrote to Channing

60"Death v. Historian," T1me, January 19, 1931; Nat1on, CXXXII (January 21, 1931), p.59。 p. 661 .

61 American Historical Review, XXXVI (April, 1931), 
at that time:

Absence over seas has prevented an earlier recognition of the significance of your announced purpose to take the Chiltern Hundreds. That dec1sion w111 remove the direct teaching of a man who has for two generations been a pedagogical power. Constantly I meet former students who "studied with Channing." You have been a great force in the rational teaching of American History--accurate, live, modern, interesting, memorable.

You have also been a trainer of teachers--the country is studied [s1c] with men and women--who have been directed by you into flelds of research; and who have learned from you the inestimable lesson of the value above all other things of truth--so far as truth can be discerned. of your place as a writer of history I need not enlarge. You are the only trained scholar who has accomplished what Bancroft attempted- $\infty$ a scholarly history of the United States of America, from discovery to the author's own day. I doubt whether any writer in the next generation $w 111$ repeat that task; it demands youth, health, opportunity, and unconformable pluck. Bancroft is shelved. I expect Channing to be read for a century. 62

Th1s last prediction was certainly over-optimistic。

Despite Morison's statement quoted at the head of this chapter that he st111 finds Channing useful on specif1c subjects; despite the fact that he used some of Channing's volumes in courses at Harvard as late as the years just after World War II and found them to be very popular with the students; 63 and desplte Herbert W. HIII's statement that much of Channing's work "Is st111 useful and has stood up very we11"64--despite

62 Albert Bushnel1 Hart to Edward Channing, Apr11 14, 1929, "Resignation" folder in possession of El1zabeth Channing Fuller, Chatham, Massachusetts.

63 Interview with Samuel El1ot Morison, June 9, 1967, Cambridge, Massachusetts.

64 Letter to the author from Herbert W. H111, September 16,1966 . 
all these things, apparently, virtually no one, even graduate students, reads the Great Work anymore. The Macmillan Company has now let 1 t go out of print. It $1 \mathrm{~s}$ probably true, as Crane Brinton says, that Channing's work tends to be under-rated today, Indeed even ignored to a certain extent. The most that can be sald for Channing's Influence today 1s that it is an Indirect one. Channing, Hart, and Turner, says one recent writer, "were the leading historians in the period 1890 to 1930." As such, they "helped to train American h1storlans of the generation immediately prior to that which is now in power," including Mor1son, Merk, and W1ll1am L. Langer. The present generation, in turn, looks to these three, plus Schlesinger, as 1 ts mentors. 65

Willam Roscoe Thayer stated emphatically in 1905 that "The cooperative history will not, it is clear, displace the work of the single historian." 66 Channing himself once expressed an aversion to such series: "I am strongly 1mpressed with the undeslrablity of 'serles' from the teacher's and reader's point of view. There are always a few good books in these publications and a lot of very poor ones." 67 However,

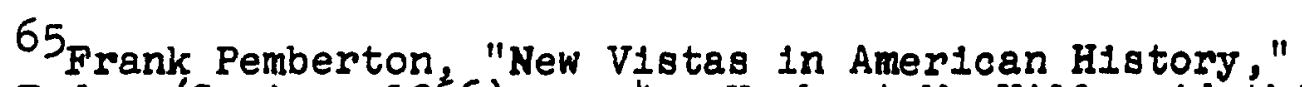
Harvard Today (Spring, 1966), p. 4. Herbert $w_{0}$ H111 sald this of his Harvard days: "Of the men I saw and got to know well-Channing, Schlesinger, Merk, and Morison, all of whom were distinct characters--I think Channing had more 1deas." (Letter to the author, September 26, 1966.)

66 w11liam Roscoe Thayer, "The Outlook in H1story," Atlantic Monthly, XCVI (July, 1905), p.77.

67 Channing to Brett, September 4, 1919, Macmilian Collection. 


\section{9}

the trend toward series with individual authors writing the volumes on the1r own speclalties, already underway even in Channing's day, w11l doubtless continue. Channing's Great Work, Indeed, will surely be the last mult1-volume study of all United States history by a single author. What an accomplishment 1t was, however, for when it was written!

T1me has passed Edward Channing's historical works by, and many of his methods. This should not be lamented. Channing himself knew it would happen. "No h1storian can hope to live as can a poet or an essayist," he once wrote, "because new facts w1ll constantly rise to invalidate his most careful conclusions."68 But Edward truly was a great Channing, and his work truly was a great work. Something of a transitional figure between the "old" and the "new" history, Channing can also be Justiflably consldered one of the flrst of the "scient1f1c" school of American historians. He founded no "school" of history himself, but he did mold hundreds of scholars. He is noted for no all-encompassing interpretation of American h1story, but he did make hundreds of worthwhile interpretations. Among Channing's weakest points were his literary style and his ab1lity to synthesize. However, even with his stylistic problems, h1s meaning was always clear. And his meticulous h1storical techniques can well serve as a model even

68 Edward Channing, A History of the United States, Volume V: The Per1od of Trans1tion, 1815-1848 (New York: The Macmilian Company, 1921), p. 305. 


\section{0}

today. Finally, the wholeness of vlew of a work like Channing's History, with one author covering virtually the entire span of American history, was a qual1ty which the mult1authored series of today simply cannot duplicate. In short, Edward Channing deserves always to be remembered as "one of the glants of American historlography."69

${ }^{69}$ DeNovo, "Edward Channing's 'Great Work' Twenty Years After," p. 257. 
NOTES ON SOURCES

I. PRIMARY MATERIAL

In a work of this kind, primarliy historlographical In nature, the writings of Edward Channing himself obviously constitute a major primary source even though they are ava11able in published form, for 1 it is his work that is being evaluated.

One Channing effort which had not appeared in print unt1l 1967, when Channing's grandson, W1llard P. Fuller, Jr., privately printed a limited number of copies, was his autoblography. Channing Intended to call 1t "Recollections of a H1therto Truthful Man," and the forty pages of single-spaced typlng he had completed by his death are a gold mine of biographical information. Unfortunately, the narrative stopped with 1896, so that Channing never covered the years of the Great Work.

Though several of the manuscript collections contained Interesting and helpful 1tems, by far the most valuable single one was the Edward Channing file of the Macmilian Authors Collection in the Manuscript Division of the New York Publ1c Ilbrary. It contains two boxes of material, mostly correspondence between Channing and Macmilian Company President George P. Brett in the years 1895 to 1931. The collection was a source of personal information on Channing, the progress on his writings, his own evaluation thereof, the relationship between Channing and his publisher, and, to a limited extent, sales figures for his books. 


\section{2}

Interviews with those who knew Channing in one way or another were extremely interesting, and helpful primarily in that they allowed a personal touch otherwise not possible. The same is true of the numerous letters to the author from Channing acquaintances. Among those individuals who were especlally helpful in these two areas were Paul H. Buck, E。 E。 Dale, Robert H. Haynes, Frederick Merk, Samuel El1ot Morison, Merle Curt1, Herbert W. H1l1, Edward C。K1rkland, R1chard L。 Morton, Kenneth B. Murdock, Elliott Perkins, Arthur P.Whitaker, and Channing's two daughters, Allce Channing and Ellzabeth Channing Fuller, and grandson, Willard P.Fulier, Ir。

The secretary's reports of the Harvard graduating class of 1878 proved helpful, particularly the brief notices which Channing submitted himself。

Finally, the honors thesis which Channing's grandson, John Channing Fuller, wrote as a senior at W1ljlams College in 1943 was a much more useful source than one might assume. True, the work, entitled "Edward Chann1ng: Essays on The Man, The Teacher, and The Writer," sometimes gave evidence of the familial relationship of author and subject and of the undergraduate status of the author. Considering those things, however, it was an excellent plece of work.

\section{SECONDARY MATERIAL}

The most helpful 1tems in this category were the various brier efforts at assessment of Channing utilized in the eleventh chapter: Weaver, DeNovo, Fahrney, F1sh, Morison, 
Lowell, and Fuller. There is really no need to say anything further about them here.

Only a few other items are worthy of speclal mention. Both Michael Kraus (The Writing of American H1story, 1953), and Harvey W1sh (The American Historian, 1960) include brief assessments of Channing and help place him in proper perspective in the over-all story of American historical writing.

The many reviews of Channing's books, showing how they were evaluated at the time, were quite useful in determining how to evaluate them now. 


\section{I。 PRIMARY MATERIAL}

A. Works of Edward Chann1ng*

1. Unpublished

Channing, Edward. "The Loulslana Purchase." Ph. D。thesis, Harvard University, 1880。 Harvard University Archives。

"Recollections of a Hitherto Truthful Man."

Incomplete autoblography written by Channing in 19291930; In possession of Elizabeth Channing Fuller, Chatham, Massachusetts.

Collection of early writings in possession of Elizabeth Channing Fuller, Chatham, Massachusetts.

2. Books

Channing, Edward。 First Lessons in United States H1story.

New York: The Macmilian Company, 1903.

A History of the United States. S1x volumes.

New York: The Macmilian Company, 1905-1925.

- The Jeffersonian System, 1801-1811. New York:

Harper and Brothers, Publishers, 1906 .

Use. New York: The Macmilian Company, 1900.

A Students ' History of the United States. New

York: The Macmilian Company, 1898. Rev1sed 1n igo4,

1913, 1919, and 1924 .

Cambridge: At the University Press, 1896.

* Several minor 1tems 11sted in the B1bliography of Edward Channing by George w. Robinson (Cambridge: Harvard University Press, 1932), are not included here because they were of no use in this study. On the other hand, a few pleces are 11 sted here of which Robinson was e1ther unaware or did not see fit to include. The two together surely cover everything of $81 \mathrm{~g}^{-}$ nificance which Channing ever wrote. 
in consultation with Susan JoGinn。 Elements of Vin1ted States H1story. New York: The Macmilian Company, 1910 .

, and Albert Bushnel1 Hart. Guide to tre Study of American H1story. Boston: Ginn and Company, Publishers, 1897 .

, and Freder1ck Jackson Turner. Gulde to

the Study and Reading of American History. Revised and Augmented Ed1t1on. Boston: Ginn and Companỳ, 1912.

, and Marion Florence Lansing. The Story of the Great

Lakes. New York: The Macmillan Company, 1909.

H1gginson, Thomas Wentworth, and Edward Channing. Engl1sh H1story for American Readers, New York: Longmans, Green, and Company, 1893.

Channing, Edward, and Archibald Cary Cool1dge. Ed1tors. The Barrington-Bernard Correspondence and Illustrative Matter, 1760-1770. Harvard Historical Studies, Volume XVII。 Cambr1dge: Harvard Un1vers1ty Press, 1912.

3. Miscellaneous

Channing, Edward. "The American Board of Commissioners of the Customs," Proceedings of the Massachusetts H1storlcal Soclety, XIIII (October, 1909 June, 1910), pp.477-490。 "The American Colonies," American Supplement to Encycloped1a Britann1ca. Ninth Edition. Volume II, pp. 305-306.

"Commerce During the Revolut1onary Epoch," Proceedings of the Massachusetts H1storical Society, XLIV (October, 1910-June, 1911), pp.364-377。

"The Companions of Columbus," in Justin Winsor, ed., Narrative and Critical History of America; II, pp. 189-216. Boston: Houghton, M1ffiln and Company, 1886.

"D1d the Fathers Land on Plymouth Rock on Fore father's Day?" Magazine of American H1story, XIII (January, 1885), p。103。

"A Few Remarks on the Origin of New England Towns," Proceedings of the Massachusetts Historlcal Society, III $(1891-92)$, pp. 242-263。

"An Historical Retrospect," American Historical

Rev1ew, XXVI (January, 1921), pp。191-202。 
"Just1n W1nsor," American H1storical Rev1ew, III (January, 1898), pp.197-:02。

"Kentucky Resolut1ons of 1798," Amer1can H1stor1cal Rev1ew, XX (January, 1915), pp。333-336。

"Memolr of Thomas Wentworth Higginson," Proceed1ngs of the Massechusetts H1stor 1cal Soclety, XLVII (October, 1913-June, 1914), pp. 348-355.

The Narrasansett Planters: A Study of Causes. Johns Hopkins UnIversity Studies in HIstor1cal and Pol1t1cal Sclence. Herbert B. Adams, ed. Fourth Serles, Volume III. Baltimore: No Murray, 1886.

"The Present State of Historical Writing in America," Proceedings of the American Ant1quarian Soc1ety, XX (October, 1910), pp。427-434。

"The Relation of Geography to History," Journal of Proceedings and Addresses, pp。192-196. St. Paul, Minnesota: National Education Association, 1895.

"Remarks on Charles Deane," Proceedings of the Massachusetts H1storlcal Soclety, $v(1890), \mathrm{pp}, 135-136$.

"Remarks on the course and landing of the P1lgrims at Plymouth," Proceedings of the Massachusetts Historical Society, XVII (1903), pp.381-382。

"Remarks on crimes and their punishment in the colonial per1od," Proceedings of the Massachusetts H1s torical srelety, XIX (1905), p. 190 .

"Remarks on a recent visit to Jamestown and other historical places in Virginia," Proceedings of the Massachusetts H1storical Soclety, XIV (1900-1901), p。175.

"Remarks and resolutions occasioned by the res18nation of Samuel Abbott Green," Proceedings of the Massachusetts H1stor1cal Soc1ety, XLVII (October, 1913-June, 1914), pp. 129-131.

- Review of J.A. Doyle, The English in America: The Puritan Colonies, Engl1sh Historical Rev1ew, II (July, 1887), pp. 587-593.

"The Sackv11le Papers," Magazine of Amer1oan H1story, XIII (June, 1885), pp. 490-491。

"Some Recent School Books," Magazine of American History, XIII (February, 1885), pp。185'187. 
1783. Cambridge: Edward $W$, Wheeler, Printer, 1893.

Town and County Government in the English Colonies of North Amerlea. Johns Hopkins University Studies in H1storical and Political Sclence. Herbert B. Adams, ed. Second Series, Volume $X_{0}$ Baltimore: $N$. Murray, 1884.

"Trlbute to John Andrew Doyle," Proceedings of the Massachusetts Histor1cal Soc1ety, I (1907-08), pp.196-198.

"The War in the Southern Department," in Justin Winsor, ed., Narrative and Crit1cal History of America, VI, p. 469-555. Boston: Houghton, Miffiln and Company, 1887 .

"Washington and Parties, 1789-1797," Proceedings of the Massachusetts H1storical Soclety, XLVII Toctiber, 1913-June, 1914), pp.35-44。

"W11liam Penn," Annual Report of" the Amerlcan H1storical Assoc1ation for the Year 1906, I, pp. 191-197. Washington, $D_{0} C_{0}:$ Government Printing office, i908.

Winsor, Justin, with the cooperation of Edward Channing. "Territorial Acquisitions and Divisions," in Justin Winsor, edo, Narrative and Critical History of America, VII, pp。527-562。 Boston: Houghton, M1feiln and Company, 1888.

Hart, Albert Bushnell, and Edward Channing Ed1tors. Amer1can History Leafiets: Colonial and Constitutional. New York: A. Lovell and Company succeeded by Parker P. Simmons, 1892-1913.

B. Manuscript Collections

Adams Family Papers. Massachusetts Historlcal Soclety, Boston. The Henry Adams and Charles Francis Adams II files were searched]

Americal Historical Assoclation Collection. Manuscript Div1sion, Library of Congress, Washington, D.C.

Century Collection. Manuscript Division, New York Public Library.

Channing Correspondence, 1897-1929. Harvard Univers1ty Archives, Tambridge, Massachusetts。 


\section{8}

Channing Correspondence, 1884-1930。 Houghton Library, Harvard University, Cambridge, Massachusetts.

Edward Channing File, Macmillan Authors Collection. Manuscript Division, New York Public Library.

Edward Channing "Qu1nquennial File." Harvard University Archives, Cambridge, Massachusetts.

W1Illam E. Dodd Collection. Manuscript Division, Library of Congress, Washington, $D$, C.

Draper-W1sconsin H1storlcal Soclety Correspondence. State Historical Soclety of wisconsin, Madison. Photo-coples of two letters from Edward Channing to Lyman C. Draper.]

H.H. Edes Papers. Massachusetts H1storlcal Soclety, Boston.

Charles W1lliam Eliot Papers。 Harvard Unlversity Archives, Cambriage, Massachusetts.

Fields and Garrison Collection. Manuscript Division, Library of Congress, Washington, D. C.

Carl Russe11 F1sh Papers. State H1storlcal Soclety of W1sconsin, Madison. Photo-coples of Edward Channing corres. dence selected by the stafi']

Samuel A。 Green Papers. Massachusetts H1storical Soclety, Boston.

Albert Bushnell Hart Papers. Harvard UnIversity Archives. Cambridge, Massachusetts.

John Franklin Jameson Collect1on. Manuscript Div1sion, Library. of Congress, Washington, $D_{0} C$ 。

A. Lawrence Lowe11 Papers. Harvard UnIvers1ty Arch1ves, Cambridge, Massachusetts.

Papers relating to the First Town Meeting in America and the First Pubilc School. Massachusetts Historical Soclety, Boston.

"Resignation." A folder of miscellaneous loose material, much of which 1s not related to the resignation of Channing at all; in the possession of Ellzabeth Channing Fulier, Chatham, Massachusetts.

James Ford Rhodes Papers. Massachusetts H1storlcal Soc1ety, Boston. 


\section{9}

C. Correspondence

Letter to the author from Merle Curt1, August 2, 1966.

Letter to the author from Hugh 0 . Dav1s, August 2, 1966.

Letter to the author from K1mbal1 C. Elkins, October 4, 1967.

Letter to the author from Herbert $W . H 111$, September 26, 1966.

Letter to the author from Edward C. Klrkland, July 18, 1966.

Letter to the author from Samuel El1ot Morison, May, 1966.

Letter to the author from Samuel El1ot Morison, September 13, 1967 .

Letter to the author from R1chard L. Morton, July 7, 1966.

Letter to the author from Kenneth B. Murdock, September 27, 1966.

Letter to the author from El110tt Perkins, September 21, 1966.

Letter to the author from Arthur P.Wh1taker, July $21,1966$.

D. Lecture Notẹ from Channing's Courses*

Raymond Calkins, H1story 1, 1888-89.

Karl Mars El1sh, H1story 10, 1914-15.

Mason Hammond, H1story 32, 1922-23.

Ralph C11nton Larrabee, History 1, 1890-91。

Waldo Gifford Leland, H1story 11, 1900-01.

Franc1s Peabody Magoun, History 18, 1890.

Lawrence Shaw Mayo, varlous courses, 1913-1918.

Roger B1gelow Merriman, H1story 23, 1899-1900。

James Duncan Ph1ll1ps, H1story 1, 1893-94。

James Duncan Ph1lilps, H1story 11, 1895-96。

* All these are located in the Harvard University Archives, Cambridge, Massachusetts. 
Major Gabriel Seel1g, H1story 1, 1892-93.

Major Gabrlel Seel1g, History 11, 1895-96.

Albert Goodnow Wa1te, History 10, 1902-03.

T. H。 White, History 32a, 1915-16。

E. Harvard Un1vers1ty Materials

Class Book, 1878. Harvard Un1versity Archives, Cambridge, Massachisetts.

Harvard College Catalogues, 1883-1913.

Harvard University. Catalogues, 1913-1929.

Harvard College Class of 1878: Secretary's Reports: No. 1, 1879; No. II, 1884; No.III, 1892; No. IV, 1901; No.V, 1903; No.VI, 1908; No.VII, 1917; No。VIII, Fiftieth Anniversary Report, 1928。

Records of the Board of Overseers of Harvard Coilege: Volume XII, June 28, 1882-June 24, 1891 ; Volume XIII, September $30,1891-J u n e 27,1900$ 。

F. Unpublished Works

Christian, A. K. "Great Historians: Edward Channing." Manuscript of one of a series of radio addresses on major historlans by Christian, this one dated January 10, 1950.

Fuller, John Channing. "Edward Channing: Essays on The Man, The Teacher, and The Writer." Senior honors thesis, W11liams College, W1lliamstown, Massachusetts, 1943.

\section{Q. Interviews}

Intervlew w1th Paul H. Buck, June 9, 1967, Cambridge, Massachusetts.

Interv1ew w1th Allce Channing, August 18, 1966, North Chatham, Massachusetts.

Intervlew w1th E. E. Dale, May 27, 1966, Norman, Oklahoma.

Interview with Hugh 0. Davis, September 22, 1966, Tulsa, Oklahoma. 
Interviews with Elizabeth Channing Fuller, August 18 and 19, 1966, Chatham, Massachusetts. Also present: Willard

P.Fuller, Jr。

Interview with Robert $H$. Haynes, August 24, 1966, Cambridge, Massachusetts.

Interv1ew w1th Freder1ck Merk, August 22, 1966, Cambr1age, Massachusetts.

Interview w1th Samuel El1ot Mor1son, June 9, 1967, Cambridge, Massachusetts.

Interview with Mrs。Arthur M。 Schlesinger, August 30, 1966 , Cambridge, Massachusetts.

$$
\text { II. SECONDARY MATERIAL }
$$

A. Books

Adams, Henry. The Education of Henry Adams. New York: The Modern Library, 1931.

Adams, James Truslow. Henry Adams. New York: A。 and C. Bon1, Incorporated, 1933.

Ausubel, Herman. H1storlans and The1r Craft: A Study of the Presidential Addresses of the American Historical Association, 1884-1945. New York: Columbla University Press, 1950 .

Barnes, Harry Elmer. A History of Historical Writinge Norman: University of Oklahoma Press, 1937.

Baxter, James Phinney, III. The Introduction of the Ironclad Warsh1p. Cambridge: Harvard Un1versity Press, 1933.

Bellot, $H . H a l e . ~ A m e r 1 c a n$ Historlography and Amer1can H1stor1ans: A Review of Recent Contribut1ons to the Interpretation of the History of the United States. Norman: UnIversity of OkIahoma Press, 1952.

Beveridge, Albert J。 Abraham Iincoln, 1809-1858. Two volumes. Boston: Houghton Miffiln Company, 1928.

- The Life of John Marshall. Four volumes. Boston: Houghton Mifflin Company, 1916-1919.

Bowers, Claude $a_{0}$ Beveridge and the Progressive Era. Cambridge: Houghton Miffiln Company, 1932. 
Brooks, Van Wyck. The Flowering of New England, 1815-1865. [New York:] E. P. Dutton and Company, Incorporated, 1936. E. P. Dutton and Company, Incorporated, 1940. $[$ New York:]

Buck, Paul. Ed1tor. Soc1al Sciences at Harvard, 1860-1920: From Inculcation to the Open Mind. Cambridge: Harvard University Press, 1965.

Channing, Ellery. Poems of S1xty-Five Years. Edited by F. B. Sanborn. Philadelphia: James H. Bentley, 1902.

Cruden, Robert. James Ford Rhodes: The Man, The Historian, and His Work. [Cleveland ${ }^{-}$. The Press of Western Reserve Univers1ty, 1961.

Doctors of Ph1losophy and Doctors of Sclence Who Have Recelved The1r Degrees in Course from Harvard University, 18731926. Cambridge: Harvard Univers1ty Press, 1926.

Donnan, Elizabeth, and Leo F. Stock. Ed1tors. An H1storian's horld: Selections from the Correspondence of John Franklin Jameson. Philadelphia: The American Philosophical Society, 1956.

The Early Writings of Frederick Jackson Turner. Madison: University of W1sconsin Press, 1938.

Evarts, R. C. Al1ce's Adventures in Cambridge. Cambridge: The Harvard Lampoon, 1913.

Fitzsimmons, Matthew A., Alfred G. Pundt, and Charles E. Nowe11. Editors. The Development of Historlography. Harrisburg, Pennsylrania: The Stackpole Company, 1954.

Fox, Dixon Ryan. Herbert Lev1 0sgood, An American Scholar. New York: Columb1a Univers1ty Press, 1924.

Gabriel, Ralph Henry. The Course of American Democratic Thought: An Inteliectual H1story Since 1815. New York: The Ronald Press Company, 1940 .

Goldman, Eric F. John Bach McMaster: American Historian. Philadelphia: Un1vers1ty of Pennsylvania Press, 1943.

Goltschalk, Louls. Editor. Generalization in the Writing of History: A Report of the Committee on H1storical Analys is of the Soc1al Sclence Research Counc1l. Ch1cago: The UnIversity of Chicago Press, 1963. 
Grob, Gerald N., and George Athan Billias. Interpretations of American H1story: Patterns and Perspectives Volume

I: To 1877. New York: The Free Press, 1967.

HandIIn, Oscar, Arthur Meler Schlesinger, Samuel Ellot Morison, Freder1ck Merk, Arthur Meler Schlesinger, Jro, ara Paul Herman Buck. Harvard Gu1de to Amer1can H1story. Cambridge: The Belknap Press of Harvard Univers1ty Press, 1954.

Higginson, Thomas Wentworth. Part of a Man's Life. Boston: Houghton Mifflin Company, 1905.

Hutchinson, William T. Editor. The Marcus W. Jernegan Essays In American H1storiography. Ch1cago: Un1versity of Chicago Press, 1937.

Jensen, Merrill. The New Nat1on: A History of the United States During the Confederat1on, 1781-1789. New York: Vintage Books, 1950.

K1rkland, Edward Chase. Charles Franc1s Adams, Jre, 18351915: The Patr1c1an at Bay. Cambridge: Harvard Un1vers1ty Press, 1965.

Kraus, Michael. AH1story of American H1story. New York: Farrar and Rinehart, Incorporated, 1937.

of Okiahoma Press, 1953 .

Lord, Clifford L. Ed1tor. Keepers of the Past. Chapel H1ll: University of North Carolina Press, 1965.

M11ler, Perry, and Thomas H. Johnson. The Puritans. New York: Amer1can Book Company, 1938.

Morison, Samuel El10t. By Land and By Sea: Essays and Addresses. New York: Alfred A. Knopf, 1953.

Three Centurles of Harvard, 1636-1936. Cambridge: Harvard University Press, 1946.

Editor. The Development of Harvard Univergity Since the Inauguration of President E110t, 1869-1929. Cambridge: Harvard Un1versity Preos, 1230 $\ldots+\ldots=\ldots$.

Nevins, Allan. The Gateway to History. New, revised edition. Garden City, New York: Doubleday and Company, Incorporated, 1962.

Persons, Stow. American Minds: A H1story of Ideas. New York: Henry Holt and Company, 1958. 
Samue1s, Ernest. The Young Henry Adams. Cambridge: Harvard University Press, 1948.

Schlesinger, Arthur M. In Retrospect: The History of a Historlan. New York: Harcourt, Brace and World, Incorporated, 1963.

Ed1tor. Historical Scholarship in Amer1ca: Needs and Opportunities. A Report by the Committee of the American H1storical Assoc1ation on the Planning of Research. New York: Ray Long and Richard R. Sm1th, Incorporated, 1932 .

Scudder, Townsend. Concord: American Town.-Boston: L1ttle, Brown and Company, 1947.

Wells, Anna Mary. Dear Preceptor: The Life and T1mes of Thomas Wentworth Higginson. Boston: Houghton Miffiln Company, 1963.

W1lkins, Burle1gh Taylor. Carl Becker: A Blographlcal Study In American Intellectual History. Cambridge: Massachusetts Inst1tute of Technology Press and Harvard University Press, 1961。

Wish, Harvey。 The American Historian: A Soc1al-Intellectual History of the Writing of the Amer1can Past. New York: Oxford UnIversity Press, 1960.

Yeomans, Henry Aaron. Abbott Lawrence Lowe12, 1856-1943. Cambridge: Harvard UnIvers1ty Press, 1948.

\section{B. Articles}

Cappon, Lester J. "Channing and Hart: Partners in B1bliography," New England Quarterly, XXIX (September, 1956), pp. 318-340.

Caughey, John Walton. "Historian's Cholce: Results of a Poll on Recently Published American History and Blography," M1ss1ss1pp1 Valley Histor1cal Review, XXXIX (September, 1952), pp. 289-302。

Dale, E. E. "Turner--The Man and Teacher," In1verg1ty of Kansas C1ty Rev1ew (Autumn, 1951), pp. 18-28.

"Death v. Historian," Iime, January 19, 1931.

DeNovo, John A. "Edward Channing's 'Great Work' Twenty Years After," M1ssissipp1 Valiev H1stor1cal Review, XXXIX (September, 1952), pp. 257-274. 
Dunning, W1lliam A "A Generation of American Historlography," Annual Report of the American Historical Association for the Year 1917, pp. 345-354. Washington, D。C.: Government Printing office, 1920 .

F1sh, Carl Russell. "Edward Channing: America's Historian," Current H1story, XXXIII (March, 1931), pp。862-867.

Genzmer, George Harvey. "W11l1am Ellery Channing," [1818-1901] Dictionary of American Blography, IV, pp.7-8. New York: Charles Scribner's Sons, 1930 .

Jameson, J Franklin. "The American Historical Association, 1884-1909," American H1storical Review, XV (October, 1909), pp. $1-20$.

. "The American H1storical Review, 1895-1920," Amerlcan H1storlcal Rev1ew, XXVI (October, 1920), pp.117.

Lowell, A. Lawrence. "Edward Channing," Academy Publication No. 77 of the American Academy of Arts and Letters, 1932 , pp. $73-83$.

Melcher, Freder1c $G_{0}$ "George $P_{0}$ Brett," Dictionary of American Blography, XXII, pp。59-60. New York: Charles Scribner's Sons, 1958.

M1tche11, Stewart. "Henry Adams and Some of H1s Students," Proceedings of the Massachusetts Historical Soclety, LXVI (October, 1936-May, 1941), pp。294-312。

Mor1son, Samuel El1ot. "Albert Bushnell Hart, 1889-1939," Proceedings of the Massachusetts H1storlcal soclety, LXVI (October, 1936-May, 1941), pp. 434-438.

"Edward Channing: A Memolr," Proceedings of the Massachusetts H1storicai Soc1ety, LXIV Toctober, 1930June, 1932), pp. 250-284。

"A Memo1r and Estimate of Albert Bushnell Hart," Proceedings of the Massachusetts Historlcal Soclety, LXXVII (January-Dec ember, 1965), pp。28-52。

"Ob1tuary," Amer1can H1storical Review, XXXVI (April, 1931b p.661.

"Ob1tuary," Nat1on, CXXXII (January 21, 1931), p. 59.

Pemberton, Frank. "New V1stas in Amer1can H1story," Harvard Today (Spring, 1966), pp. 2-8. 
Vlets, Henry R. "Walter Channing," Dictlonary of American Blography IV, pp. 3-4. New York: Charles Scribner's Sons, 1930.

Weaver, Glenn. "Edward Channing: A L1terary Blography," Soc1al Studies, LIV (March, 1963), pp. 83-95.

W1nship, George P. "Edward Channing," D1ctionary of American Blography, XXI, pp. 166-168. New York: Charles Scribner's Son, 1944.

c. Reviews

1. The Great Work

Volume I.

American Monthly Review of Reviews, XXI (June, 1905), p. 765.

Bourne, E. G. American Historlcal Review, XI (January, 1906), pp. $390-393$.

Independent, LVIII (June 29, 1905), pp. 1479-1480.

Nat1on, LXXXI (July 13, 1905), p. 40.

Schuyler, Robert Livingston. New York Times, July 15, 1905, p. 464.

Van Tyne, C. H. Annals of the American Academy of Political and Soc1al science, XXVI (September, 1905), pp. 422-423.

Public Op1nion, XXXIX (August 5, 1905), p. 188.

Sloussat, St. George L. D1a] XXXIX (August 16, 1905), pp. 83-84. Smith, Theodore Clarke. Atlantic Monthly, XCVIII (November, 1906), pp. 702-711.

Spencer, Henry Russell. Polltical Sclence Quarterly, XXI (June, 1906), pp. $346-348$.

Thayer, W1lliam Roscoe. "The Outlook in H1story," Atlant1c MonthIy, XCVI (Juiy, 1905), pp. 65-78.

Volume II.

American Historical Rev1ew, XIV (January, 1909), pp. 364-366. A. Le A. Bookilist, V (February, 1909), p. 36.

American Review of Rev1ews, XXXIX (February, 1909), p. 251. Bruce, H. Addington. Outlook, XCI (March 27, 1909), pp. 753-754. Grant, W. I. Engl1sh H1storical Rev1ew, XXIV (January, 1909), pp. 145-146. This review actually covers both volumes I and II.

Independent, LXV (November 12, 1908), pp. 1122-1123. 
Independent, LXI (November 15, 1906), pp。1158-1172。

Johnson, Emory R. Annals of the American Academy of Political and Soc1al Science, XXXIII (March, 1909), pp。245-246.

Nat1on, LXXXVII (November 5, 1908), pp.440-441。

Sloussat, St. George Leakin. Dial, XLVI (May 16, 1909), pp. 327-329.

Volume III.

A. Le A. Bookl1st, IX (January, 1913), p。182。

Amer1can Rev1ew of Reviews, XLVII (March, 1913), p. 375.

Egerton, H.E. Engl1sh H1storical Rev1ew, XXVIII (January, 1913), pp.170-173.

Johnson, Emory R. Annals of the Amerlcan Academy of Polltical and Soc1a1 Science, XLVIII (July, 1913), pp。272-273.

Nat1on, XCV (November 21, 1912), pp。482-483.

Qut1ook, CII (November 16, 1912), p. 596.

S1oussat, St. George Leak1n。 D1a1, LIV (January 1, 1913), pp. 20-22。

Van Tyne, C.H. American Historical Review, XVIII (April, 1913), pp. 603-605.

Volume IV.

American Pol1t1cal Sclence Rev1ew, XI (November, 1917), p.793.

American Review of Rev1ews, LVI (August, 1917), p. 215.

Athenaeum, XIII (October, 1917), p. 530。

Bassett, John Spencer。 American Historical Rev1ew, XXIII (October, 1917), pp。189-192.

Beard, Charles A. New Republ1c, XI (July 7, 1917), pp.282283.

Dodd, William E。 D121, LXIII (July 19, 1917), pp。60-63.

F1sh, Carl Russell. M1ss1ss1ppl Valley Histor1cal Review, IV (September, 1917), pp. 243-247.

Nation, CV (December 20, 1917), pp.692-693. 
Spectator, $\operatorname{CxX}($ January 5, 1918), pp。16-17。

Volume $V$.

A.Ivord, Clarence $W$. M1ss1ss1pp1 Valley Histor1cal Review, VIII (March, 1922), pp。377-380。

Beard, Charles A. "The Art of History-Writing," Freeman, IV (December 21, 1921), p。356. 1922), "The Solemn Muse," New Repub11c, XXIX (January 4 ,

Book11st, XVIII (March, 1922), p。184。

Fox, Dixon Ryan。 American H1stor1cal Rev1ew, XXVII (April, 1922), pp。589-592。

Volume VI.

Beard, Charles A. "History and an Ant1dote," New Republic, XLIV (November 11, 1925), pp。310:311。

BookI1st, XXII (December, 1925), p.111.

Dodd, W1111am E。 New York Tribune, August 9, 1929.

Fox, D1xon Ryan. American Histor1cal Rev1ew, XXXI (Octcber, 1925), pp. 151-154.

Independent, CXV (JuIy 18, 1925), p.79.

Johnson, W1111s Fletcher. "Studies in H1story," North American Review, CCXXII (September-October-November, 1925), pp. $177-187$.

Kendrick, B. B. Historical Out1ook, XVI (October, 1925), pp. $283-284$.

MacDona1d, W1111am. Nat1on, CXXI (September 23, 1925), pp. 334-335.

Morrison, C. M. New York Even1ng Post L1terary Rev1ew, September 5,1925 .

Muzzey, Dav1d Sev1lle。 Pol1t1cal Sclence Quarterly, XL (December, 1925), pp.621-624。

Oberholtzer, Ellis Paxson. "American Annals," Saturday Rev1ew of L1terature, II (August 22, 1925); p. 61.

out10ok, CXLI (December 23, 1925), pp. 641-642。 
Viles, Jonas. Mississippi Valley Historlcal Review, XII (December, 1925), pp. 413-415.

W1se-nsin I1brary Bulletin, XXI (October, 1925), p. 230.

2. Miscellaneous Works

Student's H1story.

Egerton, Hugh E. English Historical Review, XIII (October, $1898)$, pp. 809-812.

Freeman, A. A. American Historlcal neview, III (April, 1898), pp. $544-548$.

Nat1on, LXVI (March 17, 1898), pp. 211-212.

Perrin, John W1lliam. Yale Revlew, VIII (August, 1899), pp. 219-220.

Shepardson, Francis W. School Review, VII (March, 1899), pp. 186- 187 .

Students History. ThIrd Revised Edition.

Chautauquan, LXXII (January 10, 1914), p. 382 .

Educationa] Rev1ew, XLVII (January, 1914), p. 97.

Independent, LXXIX (August 17, 1914), p. 250.

Nation, XCVIII (May 7, 1914), pp. 548-549.

Amerlcan H1story Leaflets.

Magazine of American History, XXVIII (November, 1892), pp. $399-400$.

The Great Lakes.

American H1storical Review, XV (October, 1909), pp. 189-190.

A. L. A. Booklist, V (May, 1909), p. 133.

American Review of Reviews, XXXIX (May, 1909), p. 639.

Burpee, Lawrence J. D1al, XLVII (July 16, 1909), pp. 45-46.

Independent, LXVI (June 3, 1909), pp. 1239-1241.

Literary D1gest, XXXVIII (May 22, 1909), pp. 898-899.

Nation, LXXXIX (Ju1y 8, 1909), pp. 36-37. 
New York Times, May 8, 1909, p. 290.

Gulde.

American H1stor1cal Rev1ew, II (January, 1897), pp.357-358.

Nat10n, LXIII (November 26, 1896), p. 409.

Stelner, Bernard C. Annals of the American Academy of Political and Soc1al Sclence, IX (March, 1897), pp. 84-87.

Guide, Ravised Ed1tion.

A. L. A. Bouk11st, IX (Apr11, 1913), p. 349.

Jernegan, Marcus W. Amer1can H1storical Rev1ew, XVIII (Apr11, 1913), pp. $58 \dot{9}-592$.

The Un1ted States of Amer1ca.

Athenaeum, CIX (May 22, 1897), p. 676.

Crit1c, XXVIII (May 16, 1896), pp. 349-350.

Dial, XXI (October 1, 1896), np. 193-194.

Friedenwald, Herbert. Annals of the American Academy of Polit1cal and Soc1al sc1ence, IX (March, 1897), pp. 83-84.

Scheol Rev1ew, IV (November, 1896), pp. 694-695.

Spectator, IXXVI (June 13, 1896), pp. 845-846.

The Barrington-Bernard Correspondence.

Beer, George Lou1s; American H1storlcal Review, XVIII (July, 1913), pp. 816-818.

English History for American Readers.

Athenseum, CIII (June 9, 1894), pp. 739-740.

Catholic World, IVIII (November, 1893), pp. 282=289.

Crit1c, XXIII (November 18, 1893), pp. 315-316.

Nation, LVII (September 21, 1893), pp. 214-216.

School Review, II (March, 1894), pp. 172-173.

A Short History of the UnIted States for School Use. Athenaeum, I (January 5, 1901), p. 12 . 
The Jeffersonian System.

Farrand, Max. American Historical Review, XIII (Apr11, 1908), pp. 591-595. Th1s review actualiy covers the entire American Nation series. 